\title{
33. PLIOCENE-HOLOCENE POLAR FRONT ZONE IN THE SOUTH ATLANTIC: CHANGES IN ITS POSITION AND SEDIMENT-ACCUMULATION RATES FROM HOLES 699A, 701C, AND 704B1
}

\author{
F. Westall ${ }^{2}$ and J. Fenner ${ }^{3}$
}

\begin{abstract}
The Pliocene-Holocene sediments recovered on ODP Leg 114 from Holes 699A, 701C, and 704B are the subject of a detailed investigation to interpret changes in the oceanographic environment of the South Atlantic in the vicinity of the Polar Front Zone (PFZ). The cores sample sediments at shallow (Hole 704B, $2532 \mathrm{~m}$ ), intermediate (Hole 699A, $3716 \mathrm{~m}$ ), and basinal (Hole 701C, $4647 \mathrm{~m}$ ) depths. Sites 699 and 704 come under the influence of the Antarctic Circumpolar Current (ACC) and Circumpolar Deep Water. It is possible that the upper reaches of Antarctic Bottom Water (AABW) may also affect Hole 699A. Site 701 is influenced by AABW.

Closely spaced samples were analyzed for grain-size distribution, sand fraction components, biosiliceous microfossils, organic carbon, and water content. PFZ migrations are traced using changes in bulk sedimentaccumulation rates and the abundance of the diatoms Actiniscus ssp. and Genus et species indet. 1 Fenner (this volume), as well as changes in sediment grain size and composition.

Diatomaceous sediments of Gilbert age in Hole 699A indicate that the PFZ was positioned over this site, but during the Gauss it migrated north, bringing in less productive Antarctic Surface Water. All cores document a very gradual southerly movement of the PFZ throughout the Matuyama (with some sharp fluctuations of the northen PFZ border over Site 704 between 1.45 and $1.83 \mathrm{~m} . \mathrm{y}$.). This regressive shift culminated in the late Matuyama. The latest Matuyama to earliest Brunhes record in Hole 699A has been removed by a hiatus lasting from 1.0 to $0.6 \mathrm{~m} . \mathrm{y}$., which was probably caused by intensification of the deep-reaching ACC. The corresponding interval in Hole 704B, the shallowest core, contains evidence of winnowing.

Sharp fluctuations of large amplitude and high frequency in the lithology of the sediments from Hole 704B in the eastern South Atlantic, starting at about 0.75 m.y. and characterizing the whole Brunhes Epoch, record the rapid movement of the northern border of the PFZ over the site. These reflect strong glacial/interglacial alternations in climate. To a lesser extent, lithologic fluctuations in Hole 701C reflect the same phenomenon, whereas in Hole 699A the lithology does not vary as dramatically.
\end{abstract}

\section{INTRODUCTION}

In this paper we present interpretations of the South Atlantic paleoenvironment during the Pliocene-Pleistocene period based on sedimentologic and micropaleontologic investigations of three Ocean Drilling Program (ODP) Leg 114 drill sites. Holes 699A, 701C, and 704B are in the same latitudinal zone across the subantarctic South Atlantic in the vicinity of the Polar Front Zone (PFZ) (Figs. 1 and 2). These holes were drilled in various water depths both south and north of the PFZ, thus providing sediment records of changes in the position of the PFZ and changes in the influence of shallow, intermediate, and deep water masses on sediment deposition.

Site $699\left(51^{\circ} 32.537^{\prime} \mathrm{S}, 30^{\circ} 40.619^{\prime} \mathrm{W} ; 3716 \mathrm{~m}\right)$ in the Georgia Basin and Site $701\left(51^{\circ} 59.07^{\prime} \mathrm{S}, 2^{\circ} 12.73^{\prime} \mathrm{W} ; 4647 \mathrm{~m}\right)$ in deep water at the base of the Islas Orcadas Rise are the most westerly drill sites we investigated and both are presently situated south of the PFZ. The most easterly and shallowest site investigated is Site 704 on the Meteor Rise $\left(46^{\circ} 52.757^{\prime}\right.$ S, $\left.07^{\circ} 25.250^{\prime} \mathrm{E} ; 2532 \mathrm{~m}\right)$. Sites 699 and 701 are well placed to document changes in the location of the southern border of the PFZ, as well as the influence of deep water masses. Site 701 comes under the influence of Antarctic Bottom Water (AABW), whereas Site 699 is affected by Circumpolar Deep Water (CPDW) and possibly by the upper reaches of AABW

\footnotetext{
${ }^{1}$ Ciesielski, P. F., Kristoffersen, Y., et al., 1991. Proc. ODP, Sci. Results, 114: College Station, TX (Ocean Drilling Program).

2 Université de Nantes, Laboratoire de Biosédimentologie, Sciences de la Terre, 2, chemin de la Houssiniére, 44072 Nantes Cédex, France.

${ }^{3}$ Geologisch-Paläontologisches Institut der Universität Kiel, Olshausenstrasse 40-60, D-2300 Kiel, FRG.
}

as well as the deep-reaching Antarctic Circumpolar Current (ACC) (Figs. 2A and 2B). Site 704 has a high sedimentation rate due to its position above the carbonate compensation depth (CCD). Its position to the north of the modern PFZ provides us with a detailed record of migrations of the northern border of the PFZ and also of velocity changes in the $\mathrm{ACC}$ and intermediate water masses such as the CPDW.

Stratigraphic control of the late Pliocene-Quaternary sequences examined here is provided by quantitative diatom biostratigraphy (Fenner, this volume) and by magnetostratigraphy (Clement and Hailwood, this volume; Hailwood and Clement, this volume). In addition to the boundaries identified by these authors, the Réunion Event, as determined by Fenner (this volume) in Holes 701C and 704B, is also used here. Furthermore, we follow Fenner's interpretation of the magnetic reversal at 10.44-10.74 m below seafloor (mbsf) in Hole $699 \mathrm{~A}$ as the base of the Jaramillo rather than the base of the Brunhes. This is based on the absence of the Actinocyclus ingens $\mathrm{f}$. planus acme A.i.1 and the fragmentary presence of the Thalassiosira elliptipora acme, which indicate a hiatus with sediments in the uppermost Brunhes to the upper Jaramillo missing. Apart from this hiatus in Hole 699A, all three holes provide practically continuous records through the core intervals studied, which cover the past 1.8 to $4.0 \mathrm{~m}$.y.

\section{Oceanographic Setting}

The modern PFZ (Figs. 2A and 2B) is located at approximately $50^{\circ} \mathrm{S}$ in the South Atlantic (Lutjeharms, 1985; Gordon, 1967 , 1971). It marks the boundary between colder, downwelling Antarctic Surface Water (AASW) to the south and warmer, overriding Subantarctic Surface Water to the north (Gordon, 1971). Although the PFZ is primarily a downwelling 


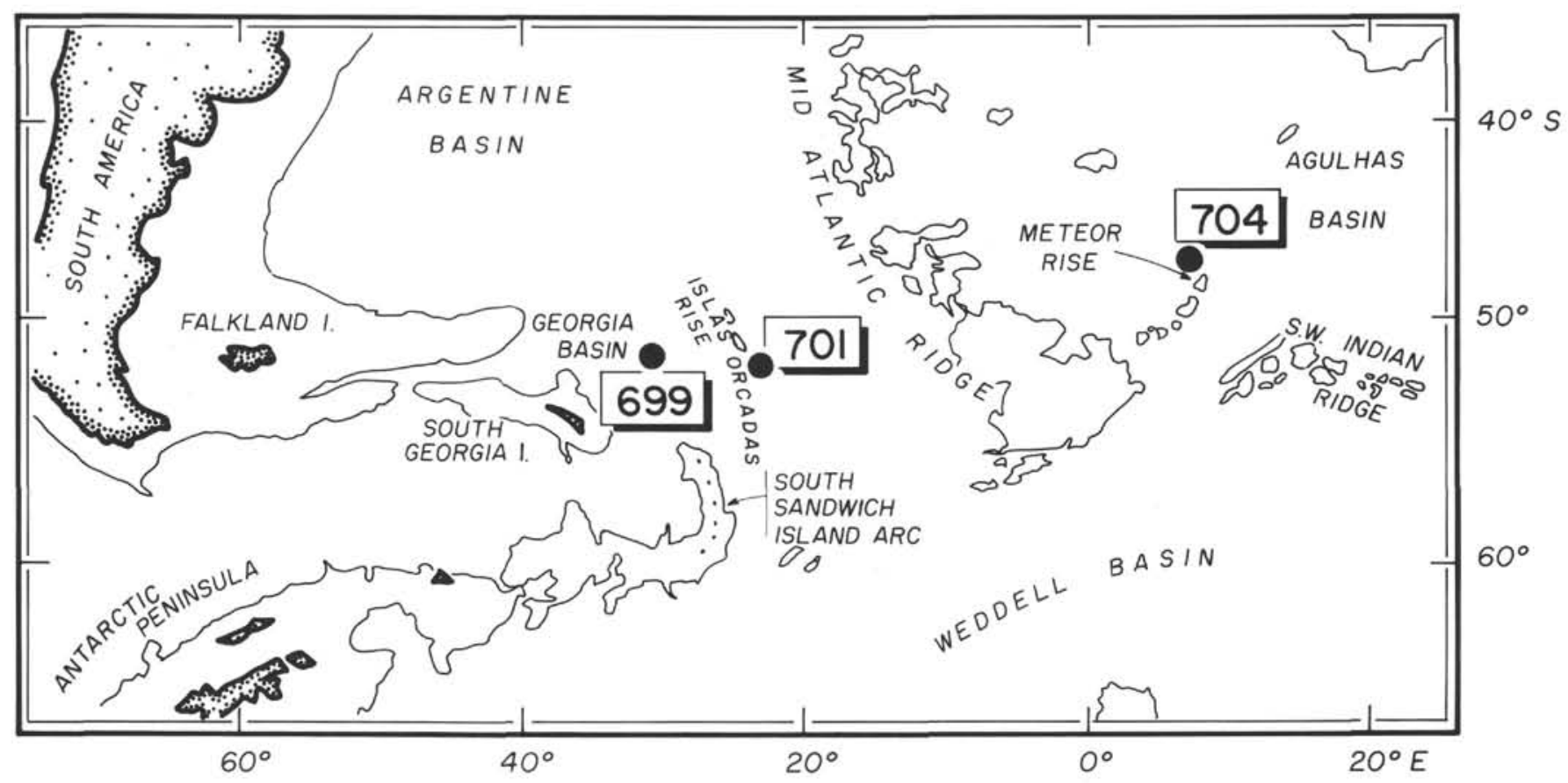

Figure 1. South Atlantic bathymetry and drill site locations.

area, there is also some upwelling in this region (Gordon, 1971). Two fronts bound the PFZ: the Polar Front itself to the south and the Subantarctic Front to the north. Analysis of the published data indicates that upwelling occurs between the two fronts.

In the eastern part of the South Atlantic the PFZ is quite broad, stretching latitudinally between about $45^{\circ} \mathrm{S}$ and $53^{\circ} \mathrm{S}$, whereas in the western part it is much narrower (Fig. 2B), extending roughly between $49^{\circ} \mathrm{S}$ and $51^{\circ} \mathrm{S}$ (Lutjeharms, 1985). The PFZ is within the ACC, which flows west to east under the influence of the west wind drift (Fig. 2B). Changes in atmospheric circulation will therefore affect the location and width of the PFZ.

High biological productivity characterizes the PFZ (Lutjeharms et al., 1985; van Bennekom et al., 1988; Burckle and Cirilli, 1987) with siliceous organisms dominating sediments deposited beneath it and siliceous-poor sediments characterizing areas north of it (Goodell, 1973; Lisitzin, 1971). Calcareous sediments are deposited above the CCD north of the front. Changes in the accumulation rates of diatomaceous and calcareous sediments on shallow rises such as the Meteor Rise can therefore be used to trace migrations of the PFZ with time.

The sediments studied are influenced by three water masses in the South Atlantic, the AABW, AASW, and CPDW (Fig. 2). AABW is a deep water mass that is formed at the ice shelves in the Weddell Sea and flows north along the western margin of the South Atlantic as well as east along the northern margin of the Weddell Basin. CPDW occupies intermediate depths (very roughly about 500 to $2500 \mathrm{~m}$; Hellmer et al., 1985; Fig. 2A) and is fed by North Atlantic Deep Water (NADW), formed in the North Atlantic (Labrador Sea). Part of this water mass is entrained within the eastward-flowing ACC.

\section{MATERIAL AND METHODS}

Samples were taken aboard ship from Holes 701C and 704B at intervals averaging between 15 and $40 \mathrm{~cm}$, depending on the sedimentation rate and core quality. In terms of thousands of years, this gives a sampling interval of 6000 to $21,000 \mathrm{yr}$ for Hole $701 \mathrm{C}$ and $7000 \mathrm{yr}$ for Hole 704B. A 2- $\mathrm{cm}^{3}$ sample was taken for water, organic carbon, and $\mathrm{CaCO}_{3}$ measurements, and a separate $5-\mathrm{cm}^{3}$ sample was taken for grain-size and component analyses from each sampling interval. Hole 699A was sampled post-cruise for grain size and component analyses only (sampling interval about 52,000 to $68,000 \mathrm{yr}$ ).

The $2-\mathrm{cm}^{3}$ samples were weighed aboard ship immediately after retrieval and subsequently freeze-dried and reweighed on shore for water content measurements. The samples were then ground, and $\mathrm{CaCO}_{3}$ and organic carbon measurements made with a Coulometrics Carbon Analyzer (accuracy $\pm 1 \%$ ).

Subsamples of the $5-\mathrm{cm}^{3}$ samples were taken for quantitative diatom analyses. The subsamples were boiled in equal amounts of $10 \% \mathrm{HCl}$ and $30 \% \mathrm{H}_{2} \mathrm{O}_{2}$ to remove $\mathrm{CaCO}_{3}$ and organic matter, and the clay fraction was separated by the Atterberg method (using sodium pyrophosphate to help dispersion). A minimum of 300 diatom valves was counted for calculations of the absolute abundance of the following siliceous microfossil groups: diatoms, silicoflagellates, radiolarians, archaeomonadaceae, phytoliths, ebridians, Actiniscus spp., sponge spicules, Spermatogonia, and Genus et species indet. 1 Fenner (this volume).

Smear slides were made from each sample for lithologic determinations, and lithologic names were assigned to the sediment according to the method of Dean et al. (1984). The remainder of the $5-\mathrm{cm}^{3}$ samples was freeze-dried to simplify sieving at $63 \mu \mathrm{m}$ to obtain the sand fraction. The $<63-\mu \mathrm{m}$ fraction was separated at $2 \mu \mathrm{m}$ using the Atterberg method to obtain silt and clay. For samples from Holes 699A and 701C, which contain no $\mathrm{CaCO}_{3}$, sodium pyrophosphate was used as a dispersion agent. For Hole 704B sediments, we used distilled water only because of the mixed siliceous and calcareous lithologies. Sand, silt, and clay contents and the silt/clay ratio were then calculated.

The dried sand fraction was used for a quantitative component analysis. A minimum of 300 grains per sample was counted. The following component classes were used: total biosiliceous, consisting of radiolarians, diatoms, sponge spi- 


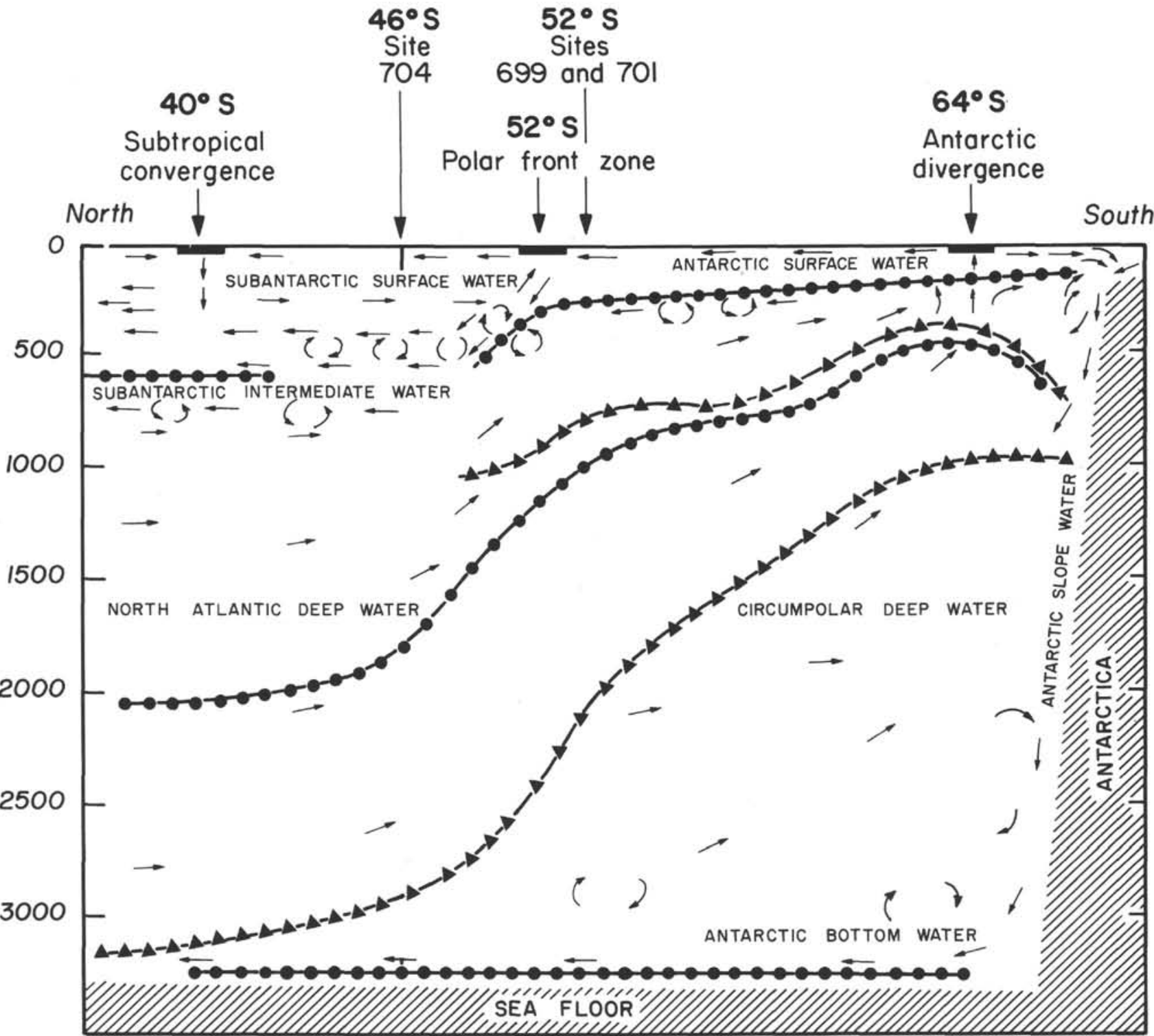

Figure 2. A. North-south cross section of the South Atlantic showing the distribution of water masses (after Gordon, 1967) and the location of Sites 699,701 , and 704. B. Location of the cores studied in relation to the present-day position of the Polar Front Zone (shaded area; after Lutjeharms, 1985). The spread of Antarctic Bottom Water from the Weddell Sea is shown by open arrows; the axis of the west-to-east-flowing Antarctic Circumpolar Current, by solid arrows (after Wyrtki, 1960).

cules, and other biosiliceous particles; total bicarbonate, consisting of whole planktonic foraminifers, broken fragments, and benthic foraminifers; nonbiogenic (excluding authigenic), consisting of terrigenous particles (predominantly quartz and feldspar with additional rock fragments and heavy minerals such as garnet, hornblende, pyroxene, biotite, olivine, spinel, and magnetite) and volcanic ash (glass, pumice, and rock fragments); and authigenic particles, consisting of pyrite, manganese micronodules, and glauconite. The proportions of these various components were calculated as a relative percentage of the whole sediment.

Bulk sediment-accumulation rates and the accumulation rates of the various components measured were calculated using sedimentation rates based on the age-depth curves presented in Figures 3-5, as well as the dry-bulk densities measured aboard ship (Ciesielski, Kristoffersen, et al., 1988).

\section{RESULTS}

\section{Sedimentology}

The Pliocene-Holocene sediments of Holes 699A and 701C are characterized by a noncalcareous lithology consisting of terrigenous and volcanic ash-bearing clayey diatom ooze to diatom-bearing clayey terrigenous and volcanic ash. In the middle to upper Brunhes sediments (Figs. 6A and 7A), the lithology is dominantly diatomaceous. In the Matuyamalower Brunhes sediments, nonbiogenic components become important. A return to diatom-rich sediments is seen in the Gilbert interval of Hole 699A.

In contrast, Hole 704B is characterized by purely biogenic sediments consisting of alternating siliceous (mainly diatoms with some radiolarians) and calcareous (nannofossils and foraminifers) or mixed siliceous and calcareous lithologies 


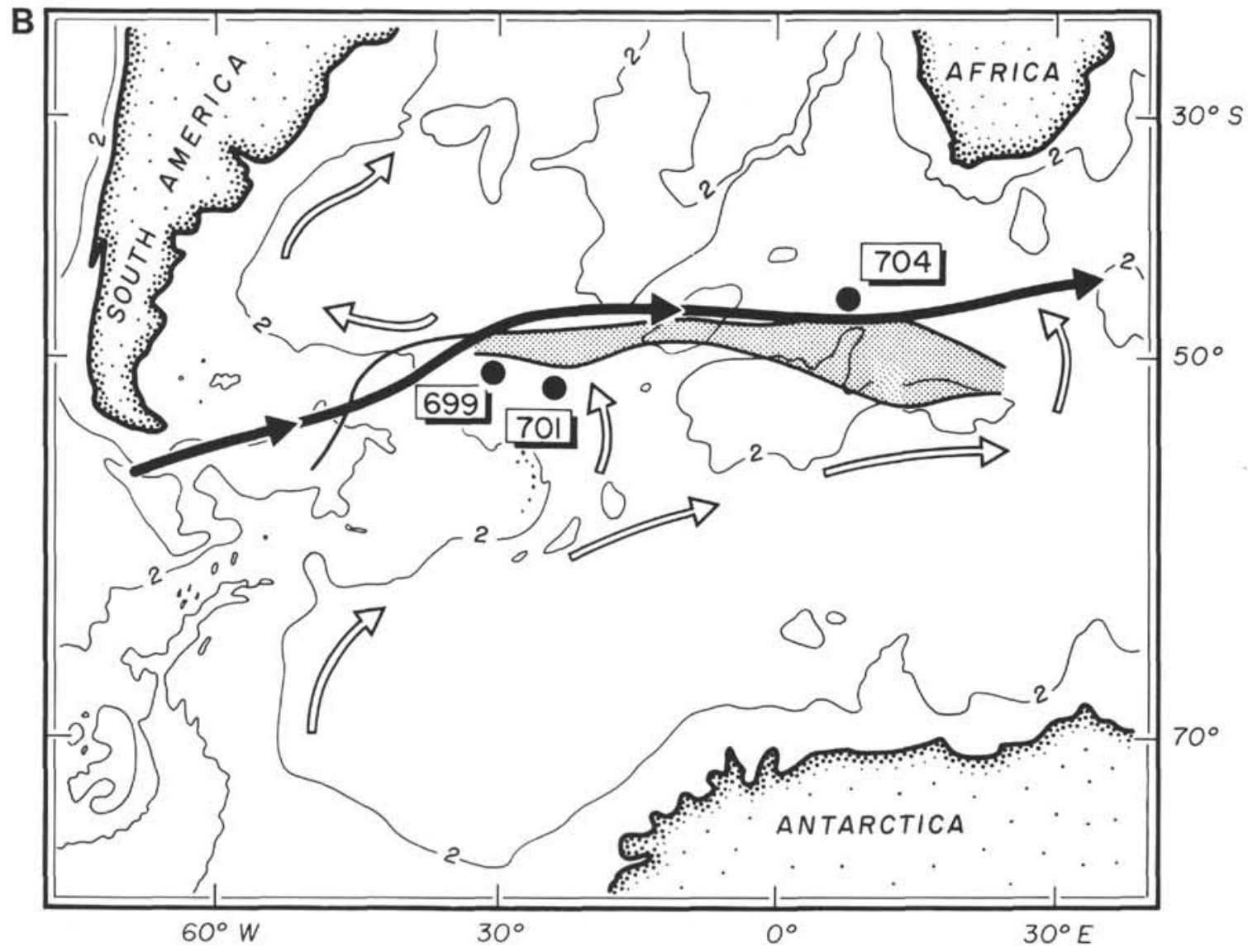

Figure 2 (continued).

(Fig. 8A). There is a slight predominance of siliceous components in the Matuyama-lower Brunhes sediments.

For ease of description, the sediments of each hole were subdivided into a number of lithologic units, based on changes in the sedimentologic characteristics as well as changes in the style of parameter fluctuation. The boundaries of the lithologic units are not strictly age equivalent. All data determined in this study are presented in Appendixes A through F. The results for each hole are illustrated individually in Figures 6 through 8 .

\section{Hole 699A}

Hole $699 \mathrm{~A}$ in the Georgia Basin lies close to a continental land mass and is, therefore, more strongly influenced by terrigenous influx than the other sites (Fig. 1). The PlioceneHolocene sediments of this hole have been divided into three lithologic units (Fig. 6A), for which the detailed sedimentologic and biosiliceous microfossil data are listed in Table 1. The raw data for Hole 699A are in Appendixes A and D.

Unit $1(0-9.6 \mathrm{mbs})$ has a middle to late Brunhes age and is distinguished by an overall diatom-rich lithology consisting of alternating horizons of diatom ooze and terrigenous/volcanic ash-bearing clayey diatom ooze. The sedimentologic and biosiliceous parameters all exhibit small-amplitude, high-frequency fluctuations that reflect the fine changes in lithology (Figs. 6A-6C). The large, predominantly silt-sized diatom component in this unit influences both compositional and size distribution parameters: total abundances of diatoms are high ( $\log 8.05$ diatom valves/g sediment; Fig. 6C), biosiliceous components in the sand fraction are more common than nonbiogenic components (Fig. 6B), and silt is by far the largest size fraction (Fig. 6A). Shipboard measurements of organic carbon recorded moderately high values $(0.24 \%$; Ciesielski, Kristoffersen, et al., 1988).

Of the other biosiliceous components counted (radiolarians, silicoflagellates, sponge spicules, archaemonadaceae, phytoliths, spermatogonia, Actiniscus spp., ebridians, and Genus et species indet. 1 Fenner [this volume]), radiolarians and silicoflagellates are the most common after diatoms. Their abundances in unit 1 are, nevertheless, very low (generally less than $2 \%$; Fig. 6C).

Unit 2 (9.6-34 mbsf) differs from unit 1 in both lithology and style of parameter fluctuations. These sediments of Matuyama age are poorer in diatoms, resulting in a predominantly diatom-bearing clayey terrigenous/volcanic ash lithology. There is a transitional interval between 10 and 15 mbsf (subunit 2A) consisting of mixed diatomaceous and nonbiogenic lithologies (Fig. 6A) with a diatom-dominated sand fraction (Fig. 6B). In contrast to unit 1, both the sedimentologic and biosiliceous parameters exhibit large-amplitude fluctuations (Fig. 6). Among the siliceous microfossil groups, Actiniscus spp. and Genus et species indet. 1 Fenner (this volume) are found only in unit 2 , where their occurrence is very rare (Fig. 6C).

The problem posed by the presence of minor amounts of $\mathrm{CaCO}_{3}$ in transitional subunit $2 \mathrm{~A}$ (marked by a $K$ on the core $\log$ in Fig. 6A) may be explained by either very high surfacewater phytoplankton production rates, in which case high diatom abundances might be expected, or mass transport of sediment downslope from an area above the CCD (N.B. Site 699 is at the foot of the Northeast Georgia Rise).

Further subdivision of unit 2 is based on the very detailed siliceous microfossil data. Subunits $2 \mathrm{~B}(18-24 \mathrm{mbsf})$ and $2 \mathrm{C}$ 


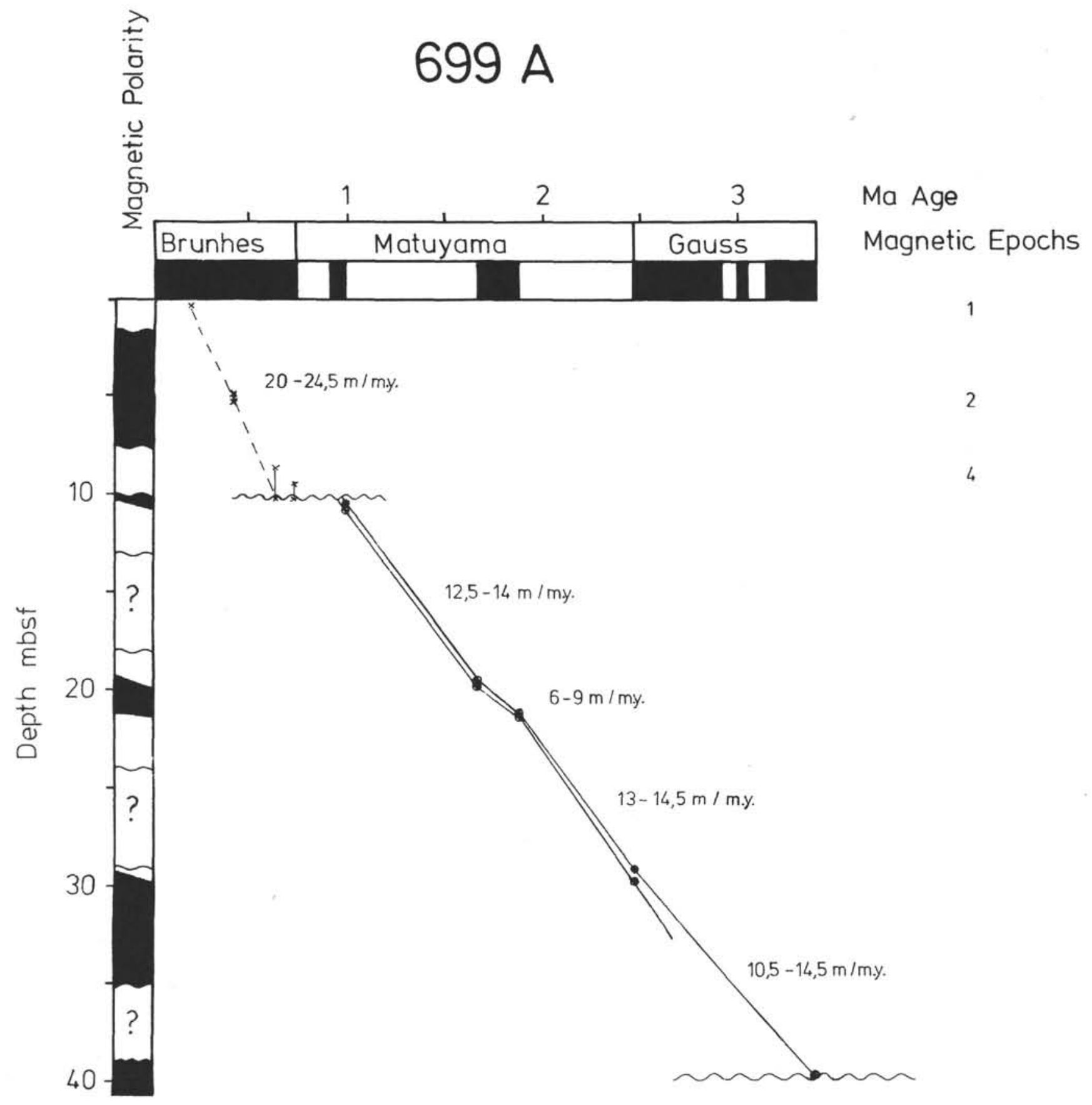

Figure 3. Age-depth curve for Hole 699A. Paleomagnetic reversal boundaries chosen after Hailwood and Clement (this volume) and Fenner (this volume). Datums used within the Brunhes magnetic Epoch: 1 = last absolute appearance datum of Hemidiscus karstenii; 2 = first absolute appearance datum of Hemidiscus karstenii; 3 = last absolute appearance datum of Stylatractus universus; $4=$ last absolute appearance datum of Actinocyclus ingens $\mathrm{f}$. planus; 5 = last absolute appearance datum of Prunopyle titan.

(28-34 mbsf) are characterized by diatom-bearing terrigenous/ volcanic ash clays in which the lowest diatom abundances in the studied section of Hole 699A were found (log 7.09 diatom valves/g sediment). The importance of nonbiogenic components is reflected in the larger clay contents (Fig. 6A), lower total diatom abundances (Fig. 6C), and higher relative abundance of nonbiogenic components in the sand fraction (Fig. 6B). In contrast to unit 1 , shipboard-measured organic carbon contents are low $(0.12 \%$; Ciesielski, Kristoffersen, et al., 1988).
Unit 3 (34-44 mbsf) is marked by the gradual increase in importance of biosiliceous components downcore except for subunit $3 \mathrm{~B}$, where there is a slight reversal of this trend. This is documented by increases in diatom abundance (Fig. 6C) and biosiliceous components in the sand fraction (Fig. 6B), as well as a larger silt fraction, the size range into which the majority of the diatoms fall (Fig. 6A). The lithology ranges from diatom-terrigenous/volcanic ash clay in the upper part of the unit (subunit 3A, 34-37.6 mbsf, and subunit 3B, 37.6-39.5 mbsf) to terrigenous/volcanic ash-bearing diatom oozes at the 


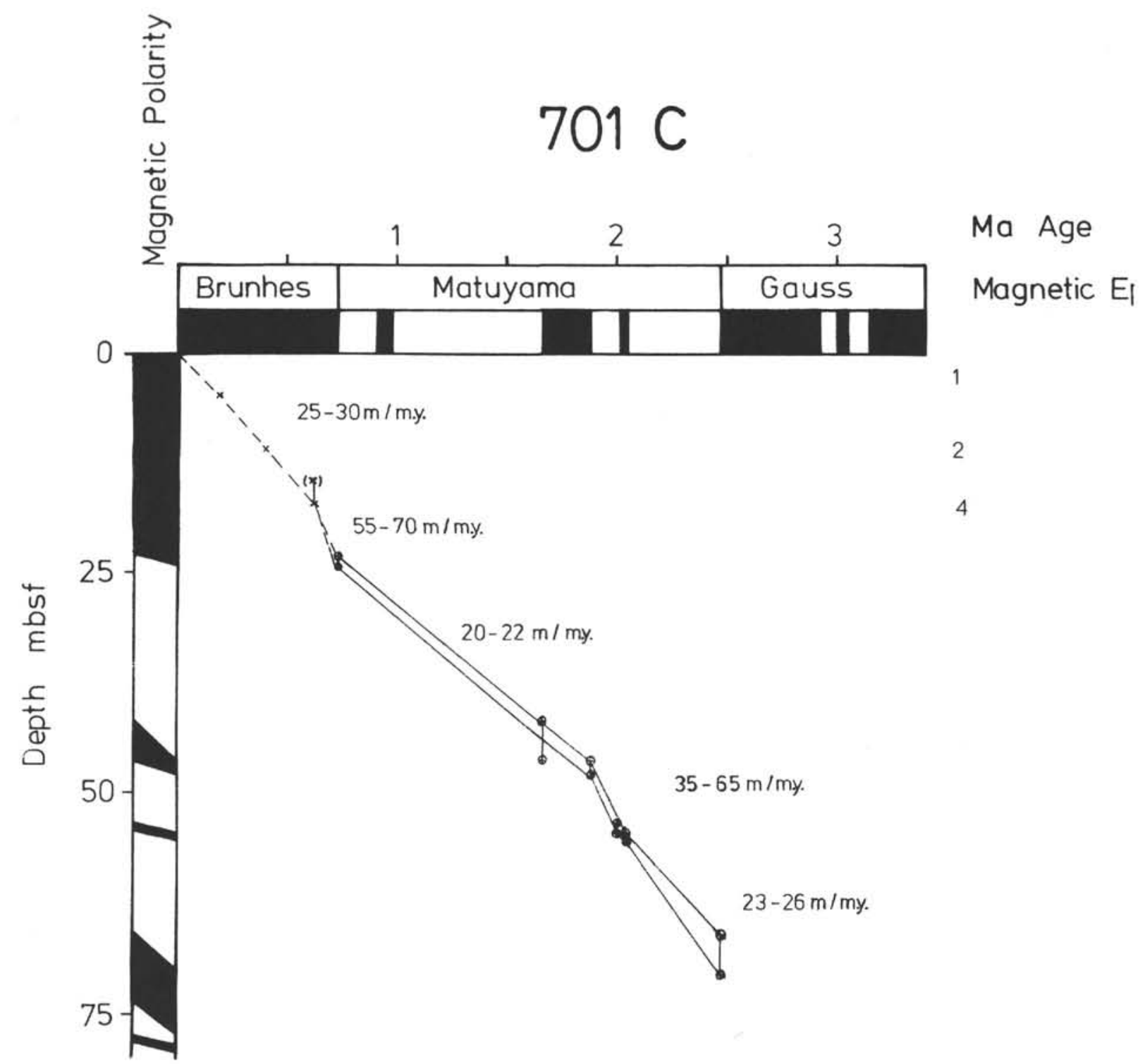

Figure 4. Age-depth curve for Hole 701C. Paleomagnetic reversal boundaries chosen after Hailwood and Clement (this volume) and Fenner (this volume). Datums used listed for Figure 3.

base (subunit 3C, 39.5-44 mbsf). Organic carbon contents, on the other hand, are extremely low $(0.04 \%$; Ciesielski, Kristoffersen, et al., 1988).

\section{Hole 701C}

Hole $701 \mathrm{C}$ is between the Islas Orcadas Rise and the Mid-Atlantic Ridge in a central oceanic location (Fig. 1). The terrigenous influence (clay and other mineral components) is, therefore, less strong in these sediments than in Hole 699A. On the other hand, clearly distinguishable volcanic ash layers, some of which are up to $10 \mathrm{~cm}$ thick, are common in Hole 701C (Fig. 7A) (see also Hubberten et al., this volume), Volcanic ash is also disseminated to a greater or lesser degree throughout the Pliocene-Holocene sediment column, depending on dilution by biogenic components. The summarized sedimentologic and siliceous microfossil data for Hole 701C are in Table 2, and the raw data are presented in Appendixes $B$ and $\mathrm{E}$.

In general, sedimentologic characteristics in Hole 701C are similar to those in Hole 699A. Two major lithologic units were distinguished in Hole $701 \mathrm{C}$ on the basis of lithologic changes and changes in the style of fluctuation of the various parameters investigated (Fig. 7A). Unit 1 (0-7 mbsf, middle to late Brunhes in age) consists predominantly of diatom ooze interspersed with thin volcanic ash/clay-bearing layers. Other siliceous microfossil groups are scarce. The large silt fraction (Fig. 7A) reflects the strong influence of mainly silt-sized diatoms, as do the moderately high total diatom abundances (Fig. 7C) and diatom-dominated sand fraction (Fig. 7B). Organic carbon contents are moderate $(0.39 \%$; Fig. 7A).

Sediments in unit 2 (7-52 mbsf) are more variable than in Hole 699A. The Matuyama-early Brunhes section was divided into subunits (Table 2 ). This subdivision is based largely on changes in lithology, the composition of the biosiliceous part of the sand fraction, and the grain-size distribution. In general, unit 2 sediments exhibit downcore parameter fluctuations of large amplitude and low frequency. The upper part of unit 2 (subunit $2 \mathrm{~A}, 7-22 \mathrm{mbsf}$ ) is distinguished by strongly diatomaceous sediments with the highest diatom abundances ( $\log 8.2$ diatom valves/g sediment) in the whole of the inves- 


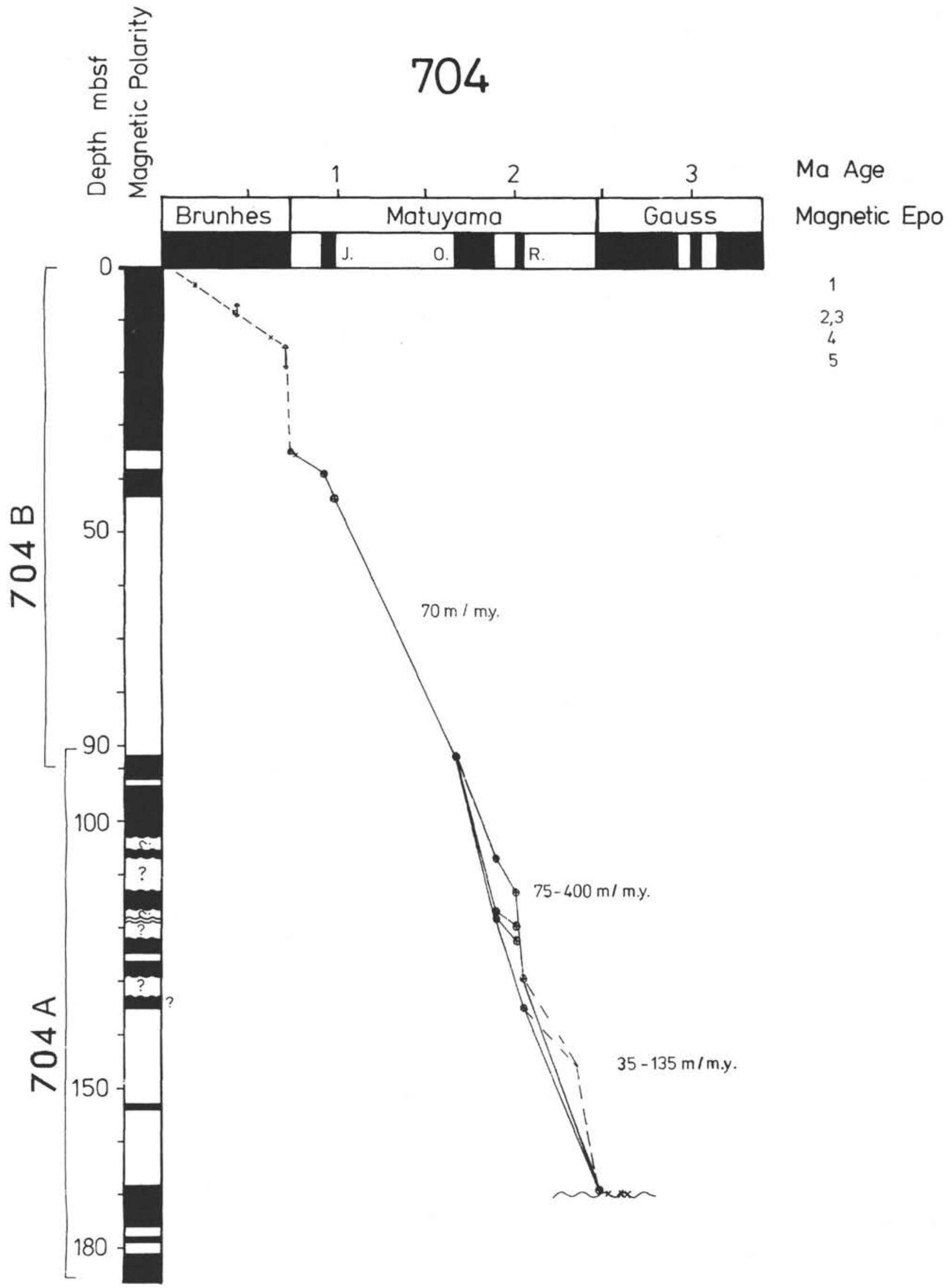

Figure 5. Age-depth curve for Hole 704B. Paleomagnetic reversal boundaries chosen after Hailwood and Clement (this volume) and Fenner (this volume). Datums used listed for Figure 3. 

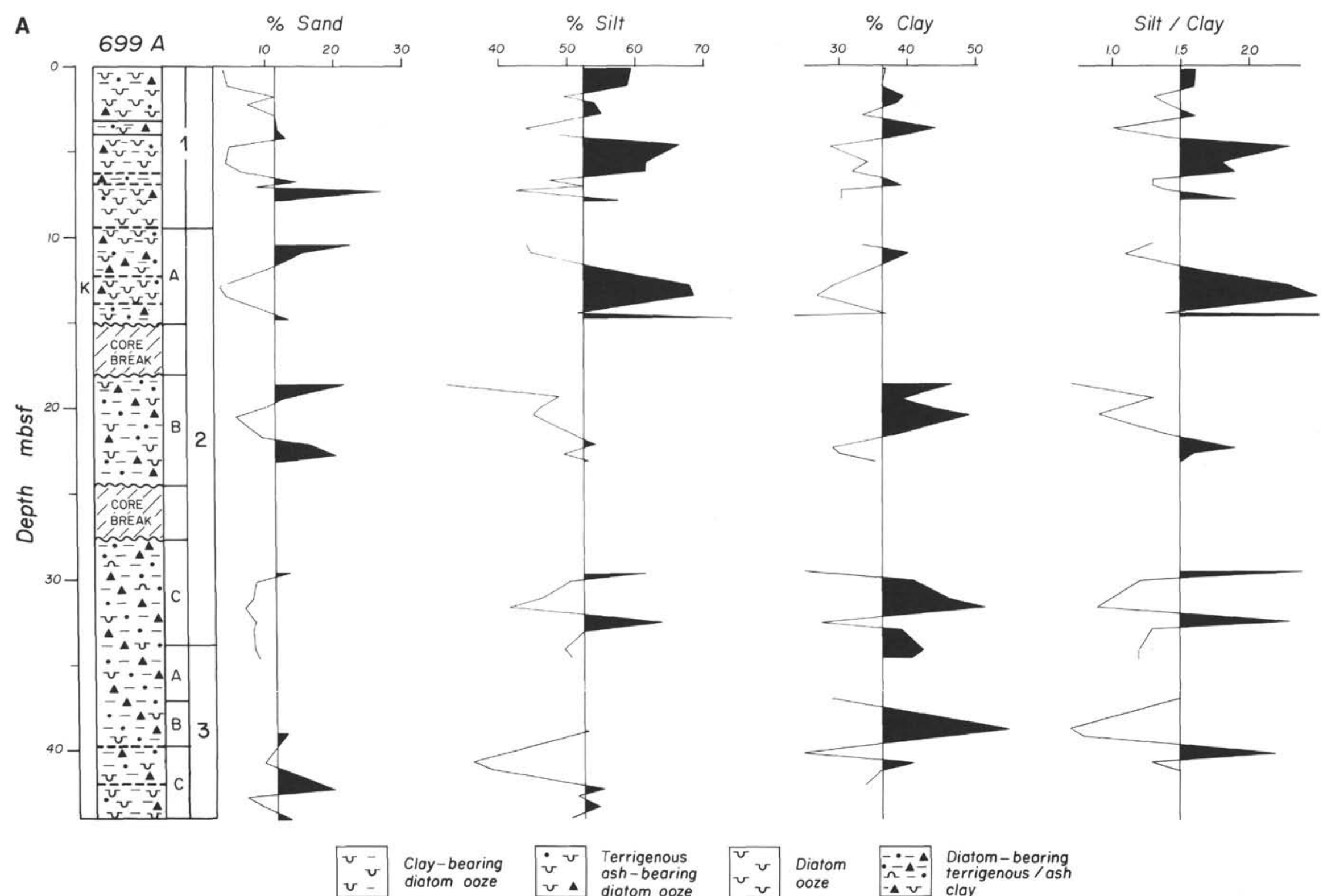


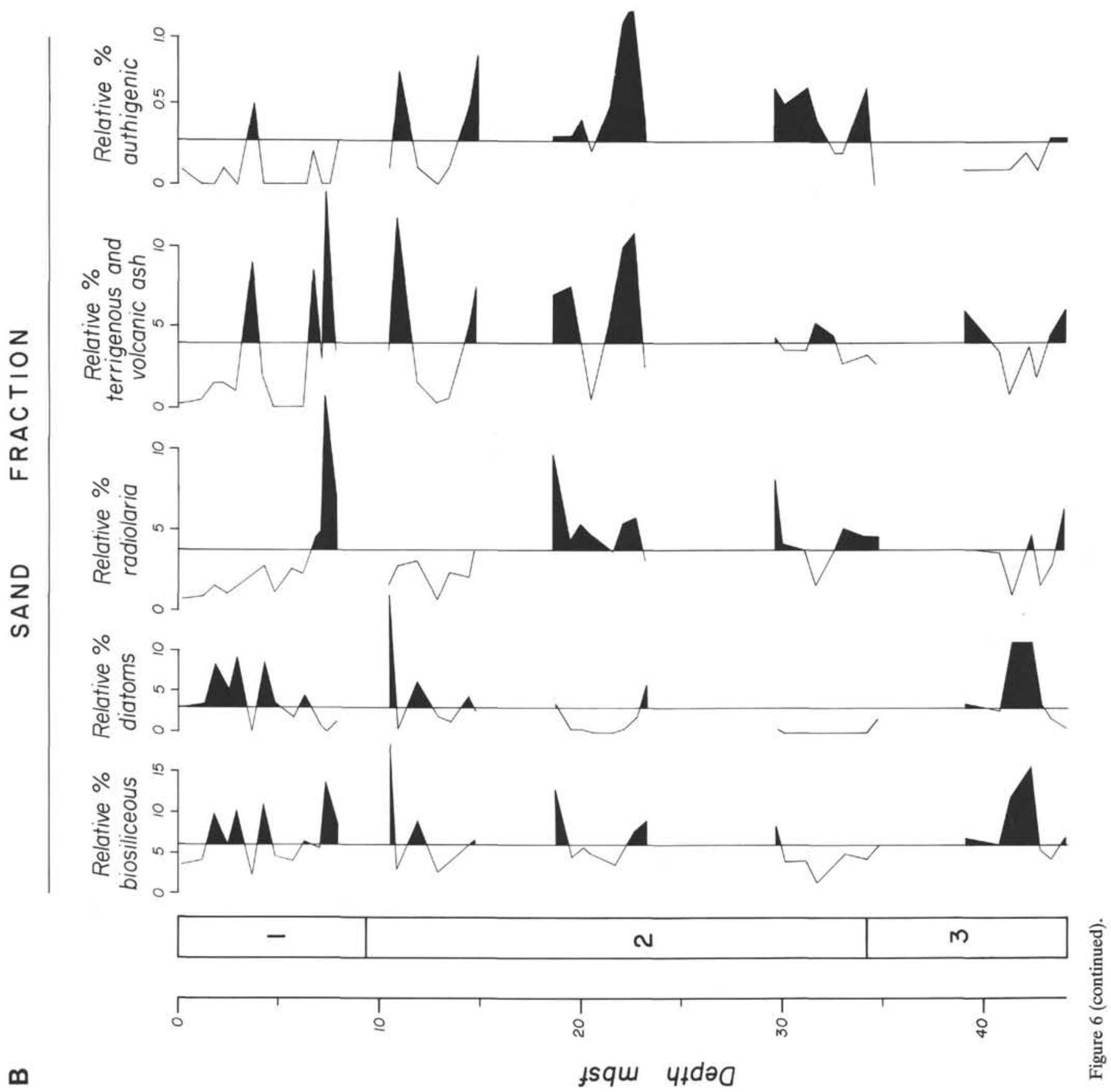

tigated part of the core (Fig. 7C). Organic carbon contents are moderately high $(0.4 \%)$. Diatom abundance, however, gradually decreases downcore below subunit $2 a$. There is an increase in nonbiogenic, sand/silt-sized ashy lithologies (subunit 2B, 23-33 m), which correlate with lower total diatom abundances. In the sand fraction, however, diatoms are more abundant than radiolarians (Fig. 7B).

The most striking downcore sedimentologic change in Hole $701 \mathrm{C}$ comes in the lower Matuyama sediments of subunit $2 \mathrm{C}$ (39.6-52 mbsf). The large fluctuations in the sedimentologic parameters of the overlying subunits are not apparent and the lithology consists uniformly of volcanic ash/clay-bearing diatom ooze in contrast to the variable lithology in the overlying sediments (Fig. 7A). The lowest organic carbon contents of the whole section are recorded in this subunit $(0.23 \%$; Fig.
7A). The occurrence of Actiniscus spp. and Genus et species indet. 1 Fenner (this volume) is sporadic and more or less restricted to unit 2 (Fig. 7C). Grain-size distribution does not change significantly throughout unit 2 (Fig. 7A).

As noted previously, one of the most noticeable differences between Holes $701 \mathrm{C}$ and $699 \mathrm{~A}$ is the composition of the nonbiogenic part of the sediment. Terrigenous components (clay plus silt and sand-sized minerals) are more common in Hole 699A whereas volcanic ash predominates in Hole 701C. There is some debate as to the origin and mode of transport, either by ice rafting and/or wind, of both the disseminated volcanic ash and the ash layers in Hole 701C. Both Sites 699 and 701 lie within the path of icebergs circling north and east in the Weddell Gyre. If the volcanic ash is largely ice-rafted, why then do we find significantly less ash at Site 699? 


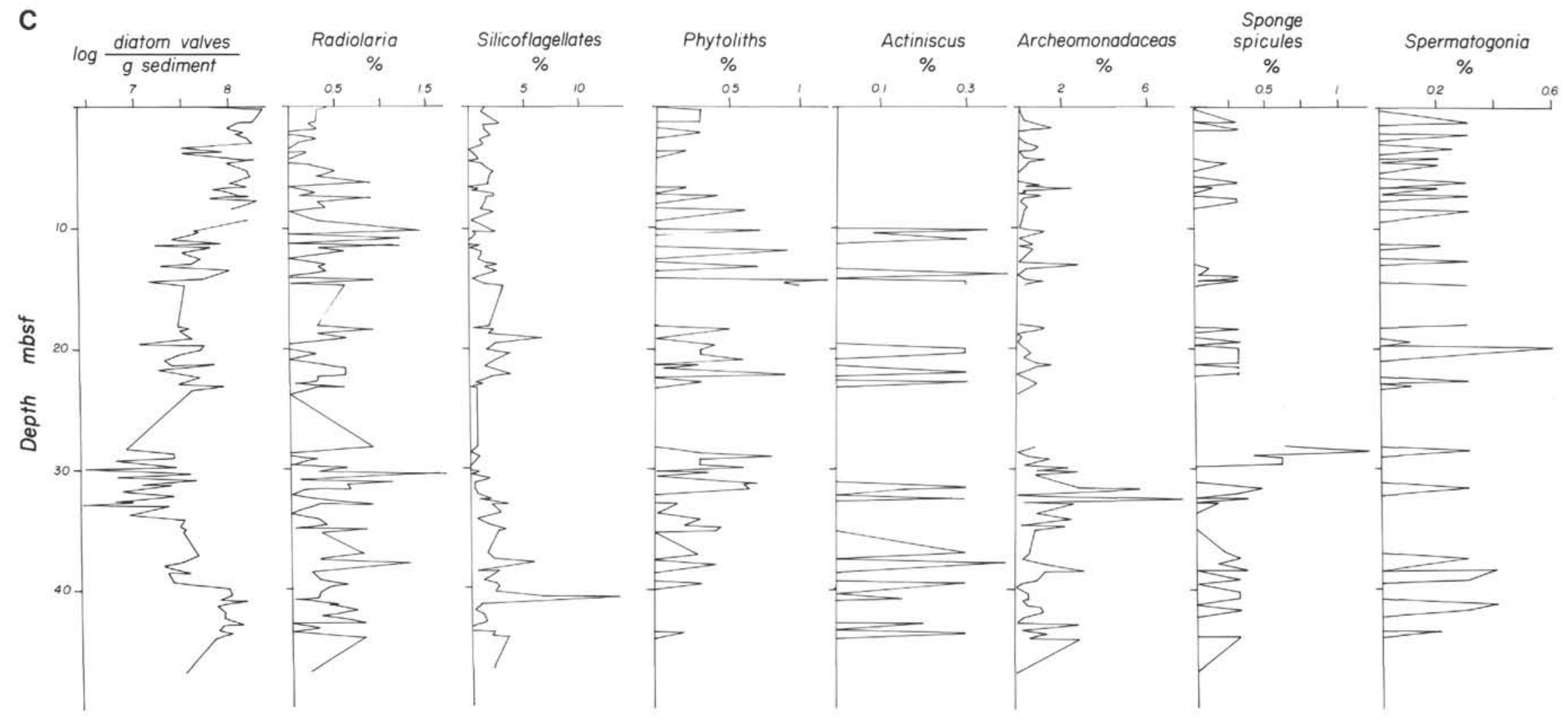

Figure 6 (continued). 

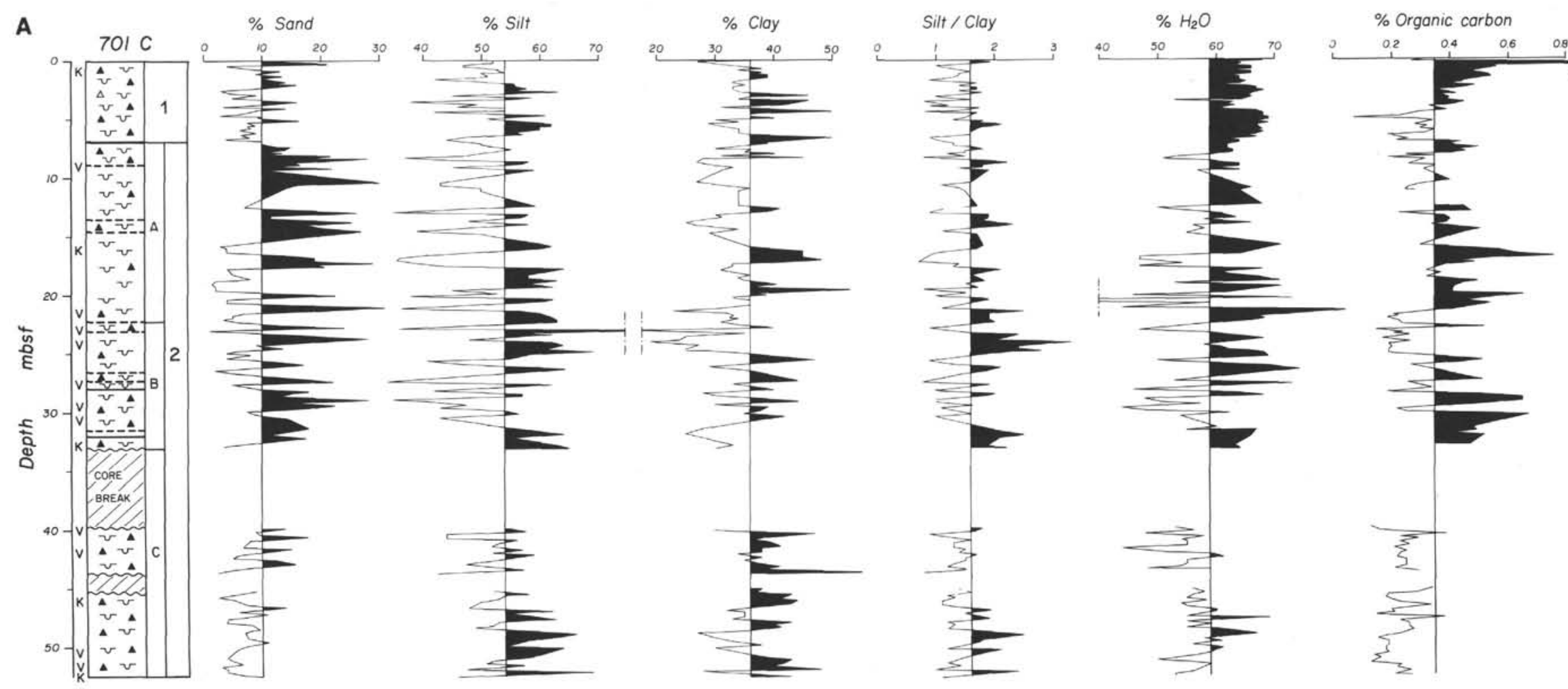

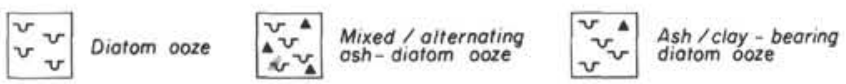

$k$-Corbonate-beoring horizon $\quad v$-volconic ash layer

Figure 7. Hole 701C. Lithology and grain size (A), relative abundance of components in the sand fraction (B), and percentage abundance of siliceous microfossils in the total siliceous microfossil assemblage $(\mathbf{C})$. 


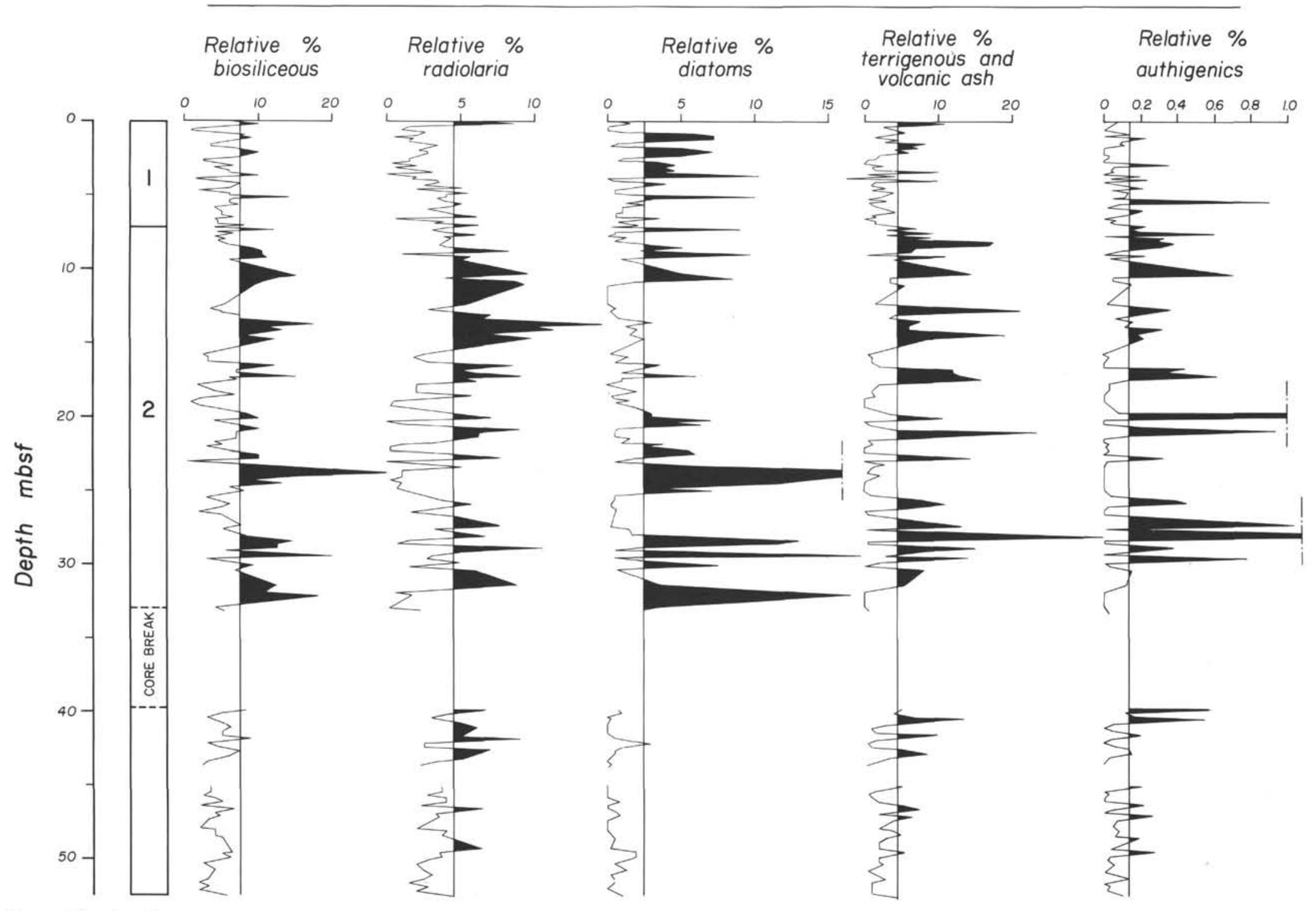

Figure 7 (continued). 


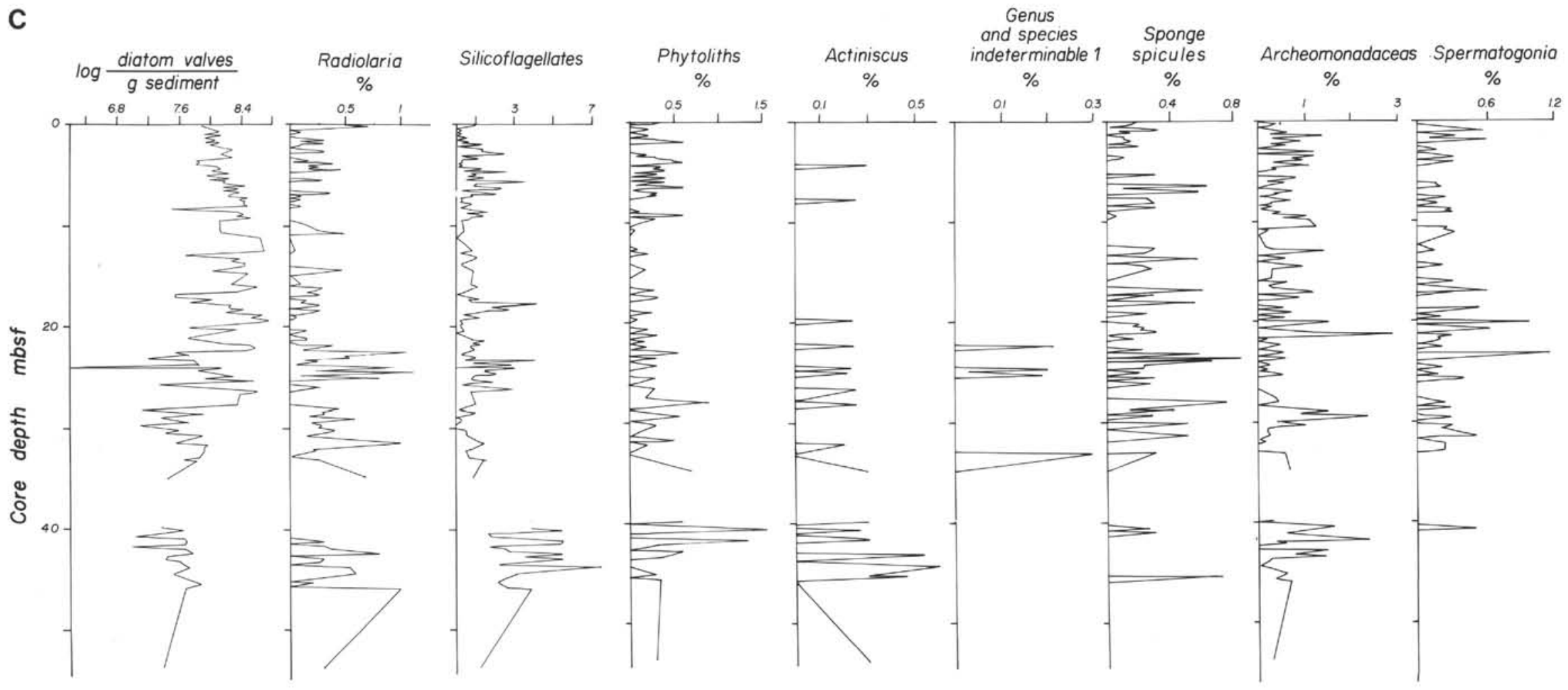

Figure 7 (continued). 


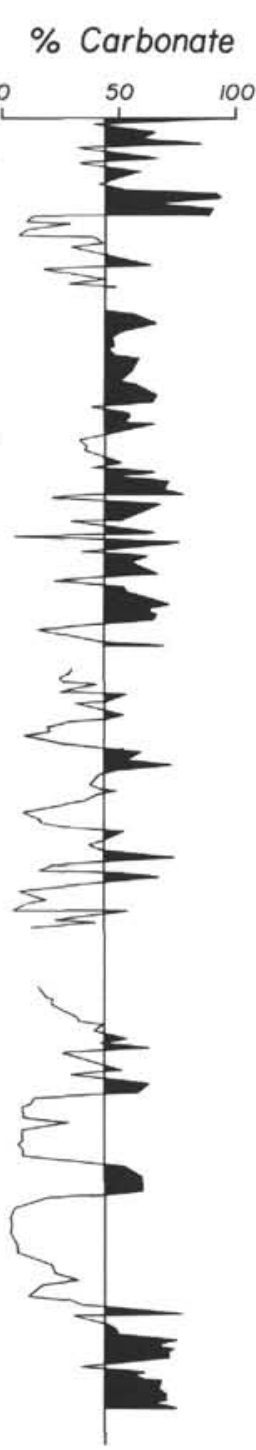

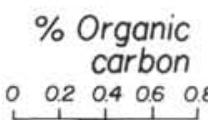
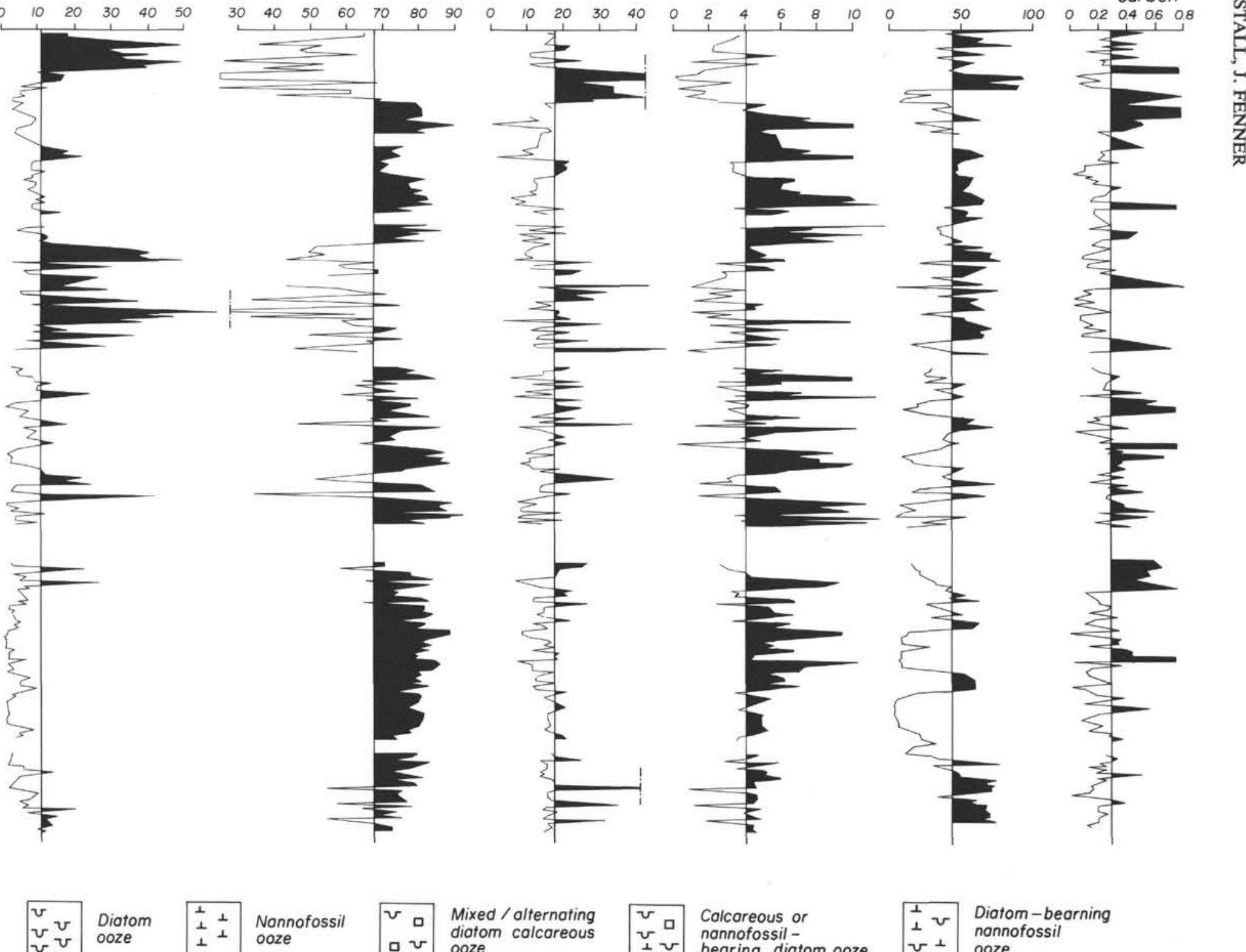

Mixed / alternating
diotom calcareous

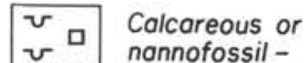

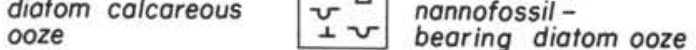

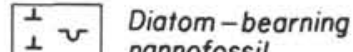
$\checkmark+$ nannofossil

Figure 8. Hole 704B. Lithology and grain size (A), relative abundance of components in the sand fraction (B), and percentage abundance of siliceous microfossils in the total siliceous microfossil assemblage (C). 


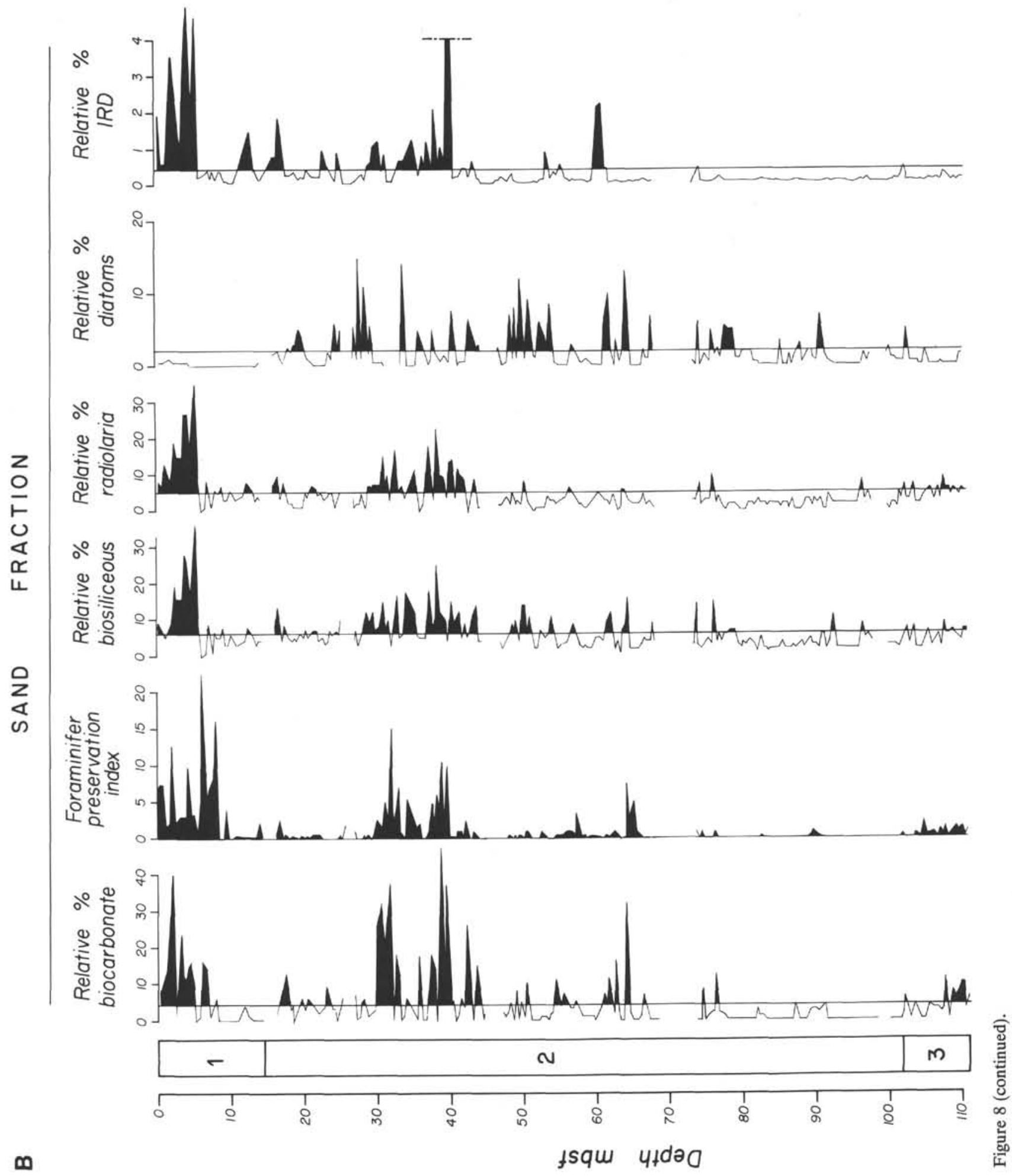

Geochemical studies of ashes from Site 701 show that the Pliocene-Quaternary ashes probably originate from the South Sandwich Islands (Hubberten et al., this volume). Figure 1 shows that Site 701 lies northeast of this volcanic arc whereas Site 699 lies northwest of it. The prevailing wind direction in this area is from the west; therefore, Site 699 does not lie within the path of wind-borne ash. However, the problem of the transport mechanism remains unsolved because ash could be either erupted or windblown onto the surfaces of icebergs and, thence, transported toward Site 701.

\section{Hole $704 B$}

The sediments of the relatively shallow-water Hole 704B ( $2532 \mathrm{~m}$ ) contrast sharply with those of the deep-water Holes $699 \mathrm{~A}$ and $701 \mathrm{C}$ ( 3716 and $4647 \mathrm{~m}$, respectively). In the first place, the lithology is completely different because this site is above the $\mathrm{CCD}$ and, therefore, calcareous components are preserved (Fig. 8A). Thus, we find alternating intervals of (1) variably pure nannofossil ooze to diatom-bearing nannofossil ooze, (2) variably pure diatom ooze to nannofossil-bearing 


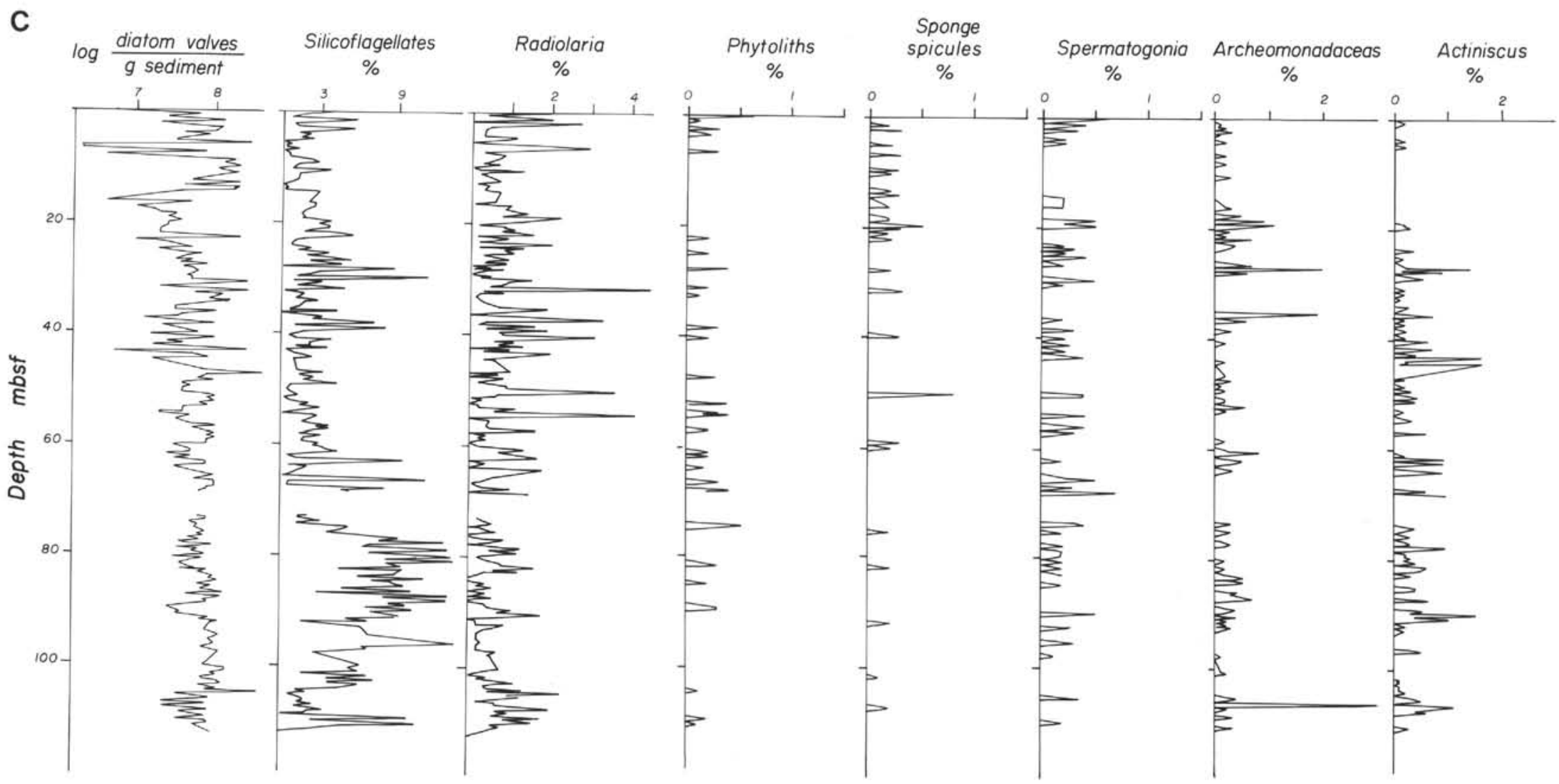

Figure 8 (continued). 
diatom ooze, and (3) highly variable or mixed calcareous and siliceous lithologies.

Second, the relatively high sediment-accumulation rate in Hole 704B has allowed us to document fine-scale changes in the sediment record (Figs. 8A-8C) that are not so readily apparent, at least in unit 1 , within the other holes. The detailed characteristics of each subunit are given in Table 3, and the raw data are presented in Appendices $\mathrm{C}$ and $\mathrm{F}$.

Unit 1 (0-14.5 mbsf, middle Brunhes) in Hole 704B is characterized by large-amplitude, low-frequency fluctuations imposed on small-amplitude, high-frequency fluctuations in the downcore plots of all of the parameters measured. This gives rise to relatively thin subunits, each characterized by fairly homogeneous properties.

The sedimentologic parameters are quite variable because of the strongly variable lithology, thus making generalizations difficult. Unit 1 sediments tend to have a fine-grained size distribution and are classified as clay-bearing to clayey silts with the exception of subunit $1 \mathrm{~A}$, which contains up to $32 \%$ sand consisting of foraminifers, radiolarians, and nonbiogenic components (terrigenous quartz and feldspar, volcanic ash, and glauconite) (Figs. 8A and 8B). The absolute abundance of diatoms ( $\log 7.7$ diatom valves/g sediment; Fig. $8 \mathrm{C}$ ) and the organic carbon content $(0.5 \%$ organic carbon; Fig. $8 \mathrm{~A})$ are moderately high throughout unit 1 , except in the nannofossil ooze interval of subunit $1 \mathrm{~B}$, where the lowest diatom abundances are encountered $(\log 6.6$ diatom valves/g sediment). In the sand fraction, radiolarians are the only siliceous microfossils found (Fig. 8B). The biosiliceous microfossil studies show that radiolarian and silicoflagellate contents, as well as other siliceous microfossil groups, are higher than in Holes 699A and $701 \mathrm{C}$ (Fig. 8C).

Unit 2 (16.5-102 mbsf, early Matuyama-early Brunhes) in Hole 704B is distinguished from unit 1 by the higher frequency and smaller amplitude of downcore fluctuations in the sedimentologic parameters and diatom abundance. In contrast to Hole 701C, there is a gradual increase in diatom abundance with depth downcore (from $\log 7.15$ diatom valves/g sediment at the top of unit 2 to $\log 7.85$ diatom valves/g sediment at the bottom), which corresponds to a gradual decrease in carbonate content (from $49 \%$ at the top of unit 2 to $30 \%$ at the bottom; Fig. 8C). Although the lithology in unit 2 is highly variable, it is generally of mixed composition with an overall predominance of biosiliceous components down to subunit $2 \mathrm{~F}$. The latter subunit (75.5-102 mbsf) consists of alternating pure diatom and calcareous oozes and is, in this respect, similar to unit 1 .

In Hole 704B the downcore increase in diatom abundance in unit 2 is paralleled by a general increase in silicoflagellates, Genus et species indet. 1 Fenner (this volume), and Actiniscus spp. An especially large increase in these microfossil groups is found at the base of unit 2 (8.4\% in subunit $2 \mathrm{~F})$. Radiolarians, on the other hand, show no significant downcore change. The overwhelming predominance of silt-sized biogenic components in unit 2 is reflected in the low relative abundances of biosiliceous, bicarbonate, and nonbiogenic components in the sand fraction (Fig. 8B). Organic carbon contents throughout unit 2 are relatively low $(0.3 \%$; Fig. $8 \mathrm{~A})$.

The lower part of the Pliocene-Holocene sediments of Hole 704B, which exhibits characteristics similar to those of unit 1 , was distinguished as a third unit (cf. Hole 699A). Unit 3 (102-110 mbsf) consists of a highly fluctuating lithology, such as nannofossil ooze, diatom nannofossil ooze, and calcareous diatom ooze, with an overall predominance of a calcareous lithology (Fig. 8A). This is also observed in the high carbonate contents $(63 \%)$ and lower total abundance of diatoms $(\log 7.6$ diatom valves/g sediment; Figs. $8 \mathrm{~A}$ and $8 \mathrm{C}$ ). There is a very slight increase in the relative abundance of siliceous, bicarbonate, and nonbiogenic components in this unit (Fig. 8B).

\section{Sediment-Accumulation Rates}

Bulk sediment-accumulation rates were calculated for units 1 and 2 as well as for the various subunits in each core (Tables 4,5 , and 6). In making these calculations we accounted for missing sediment sections due to hiatuses in Hole 699A. For the middle to upper Brunhes sediments of unit 1, the highest bulk-accumulation rates are encountered in Hole 704B (1.33 $\mathrm{g} / \mathrm{cm}^{2} / 1000 \mathrm{yr}$ ). Accumulation rates in the intermediate- and deep-water Holes 699A and 701C in the far western South Atlantic are always less than those in Hole 704B (0.88-1.08 and $0.9-1.08 \mathrm{~g} / \mathrm{cm}^{2} / 1000 \mathrm{yr}$, respectively). Detailed calculations of the accumulation rates of the various subunits, especially in Hole 704B, show a slightly more complicated picture. In this hole, the highest accumulation rates in unit 1 are found in the diatom ooze and mixed siliceous/calcareous lithology (ranging from 1.87 to $1.69 \mathrm{~g} / \mathrm{cm}^{2} / 1000 \mathrm{yr}$ ), whereas the lowest accumulation rates occur in the pure nannofossil ooze interval $\left(0.88 \mathrm{~g} / \mathrm{cm}^{2} / 1000 \mathrm{yr}\right)$. There is a very large increase in accumulation rates in this hole in the Matuyamalower Brunhes sediments of unit 2. The same correlation between lithology and the bulk sediment-accumulation rate seen in unit 1 is found in unit 2, where a mixed lithology predominates. Bulk-accumulation rates in this unit are higher than in unit 1, with the highest accumulation rates occurring in subunits $2 \mathrm{~A}, 2 \mathrm{~B}$, and $2 \mathrm{C}\left(5.32,5.42\right.$, and $4.09 \mathrm{~g} / \mathrm{cm}^{2} / 1000 \mathrm{yr}$, respectively).

Hole 701C exhibits a slight increase in the average sediment-accumulation rate between units 1 and $2(0.9-1.08$ $\mathrm{g} / \mathrm{cm}^{2} / 1000 \mathrm{yr}$ in unit 1 to $1.18-1.21 \mathrm{~g} / \mathrm{cm}^{2} / 1000 \mathrm{yr}$ in unit 2). The highest accumulation rates are found in the diatomaceous sediments of subunit $2 \mathrm{~A}$, where there is an increase to 1.61 $\mathrm{g} / \mathrm{cm}^{2} / 1000 \mathrm{yr}$. The lowest accumulation rates are found in the mixed lithology of subunit $2 \mathrm{~B}\left(0.56-0.68 \mathrm{~g} / \mathrm{cm}^{2} / 1000 \mathrm{yr}\right)$. Thereafter is a further increase downcore.

Hole 699A does not exhibit the marked variability of bulk-accumulation rates seen in Hole 704B. Sediment-accumulation rates vary between 0.88 and $1.08 \mathrm{~g} / \mathrm{cm}^{2} / 1000 \mathrm{yr}$ in unit 1 . Accumulation rates in unit 2 gradually decrease downcore from $1.05 \mathrm{~g} / \mathrm{cm}^{2} / 1000 \mathrm{yr}$ in subunit $2 \mathrm{~A}$ to $0.83-1.04$ $\mathrm{g} / \mathrm{cm}^{2} / 1000 \mathrm{yr}$ in subunit $2 \mathrm{C}$. Variable but generally low accumulation rates characterize unit $3\left(0.88 \mathrm{~g} / \mathrm{cm}^{2} / 1000 \mathrm{yr}\right.$ in subunit $3 \mathrm{~A}$ to a low value of $0.7 \mathrm{~g} / \mathrm{cm}^{2} / 1000 \mathrm{yr}$ in subunit $3 \mathrm{~B}$ ).

\section{DISCUSSION}

Our aim in making this sedimentologic and paleontologic investigation of the Pliocene-Holocene sediments from Holes $699 \mathrm{~A}, 701 \mathrm{C}$, and 704B is to reconstruct changing paleoceanographic conditions along an east-west transect of the South Atlantic in as much detail as possible. The oceanographic environment is a complex interaction of currents and water masses responding to atmospheric, ice, and land mass distributions, and, ultimately, to climatic forcing. These three holes are all either within or close to the present-day PFZ and are thus sensitive monitors of migrations of its position. At the same time, changes in sediment and microfossil composition record variations in surface-water biogenic production and sediment accumulation as well as the influence of currents on sediment accumulation.

In any investigation of the paleoposition of the PFZ, we must first establish our criteria for recording its position in the sediments. Oceanographic measurements show that the modern PFZ lies just north of Sites 699 and 701 (Fig. 2B). As noted in the "Introduction" section, one of the major characteristics of the PFZ is that it is a zone of high surface-water biosiliceous 
Table 1. Hole 699A sedimentologic and biosiliceous characteristics.

\begin{tabular}{|c|c|c|c|c|c|c|c|}
\hline \multirow[b]{2}{*}{ Unit } & \multirow[b]{2}{*}{$\begin{array}{l}\text { Depth } \\
\text { (mbsf) }\end{array}$} & \multirow[b]{2}{*}{ Lithology } & \multicolumn{5}{|c|}{ Sand fraction (relative \%) } \\
\hline & & & Biosiliceous & Radiolarians & Diatoms & $\begin{array}{l}\text { Terrigenous } \\
\text { ash }\end{array}$ & Authigenic \\
\hline 1 & $0-9.6$ & $\begin{array}{l}\text { Diatom ooze to clayey } \\
\text { diatom ooze }\end{array}$ & 6.9 & 3.2 & 3.4 & 3.2 & 0.1 \\
\hline $2 \mathrm{~A}$ & $9.6-15$ & Mixed & 7.1 & 2.2 & 4.9 & 4.1 & 0.3 \\
\hline 2B & $15-40.6$ & $\begin{array}{l}\text { Diatom-bearing } \\
\text { terrigenous/ash clay }\end{array}$ & 6.2 & 5.0 & 1.2 & 5.2 & 0.5 \\
\hline 3 & $40.6-$ & Clayey diatom ooze & 8.4 & 3.2 & 5.2 & 3.5 & 0.2 \\
\hline
\end{tabular}

Table 2. Hole 701C sedimentologic and biosiliceous characteristics.

\begin{tabular}{|c|c|c|c|c|c|c|c|}
\hline \multirow[b]{2}{*}{ Unit } & \multirow[b]{2}{*}{$\begin{array}{l}\text { Depth } \\
\text { (mbsf) }\end{array}$} & \multirow[b]{2}{*}{ Lithology } & \multicolumn{5}{|c|}{ Sand fraction (relative \%) } \\
\hline & & & Biosiliceous & Radiolarians & Diatoms & $\begin{array}{l}\text { Terrigenous } \\
\text { ash }\end{array}$ & Authigenic \\
\hline 1 & $0-7$ & Diatom ooze & 5.8 & 3.7 & 2.1 & 3.1 & 0.08 \\
\hline $2 \mathrm{~A}$ & $7-22$ & $\begin{array}{l}\text { Diatom ooze to } \\
\text { ash-/clay-bearing } \\
\text { diatom ooze }\end{array}$ & 7.4 & 5.1 & 2.3 & 6.6 & 0.2 \\
\hline $2 \mathrm{~B}$ & $22-33$ & $\begin{array}{l}\text { Alternating diatom } \\
\text { ooze-/ash-bearing } \\
\text { diatom ooze }\end{array}$ & 8.8 & 3.1 & 5.7 & 4.3 & 0.35 \\
\hline $2 \mathrm{C}$ & $39.2-52.6$ & Ash/clay diatom ooze & 4.4 & 3.9 & 0.5 & 3.4 & 0.09 \\
\hline
\end{tabular}

production, which is reflected by the predominantly biosiliceous composition of the sediments deposited beneath it (Goodell, 1973). The distribution of these sediments is, therefore, a valuable tracer of the PFZ. This phenomenon was used by Burckle and Cirilli (1987) to define the diatom ooze sediment belt in the Southern Ocean in terms of the position of the PFZ, relating poorly preserved diatom assemblages north of the front to reduced phytoplankton activity in warmer surface waters and poor preservation south of the belt to the effects of winter and spring sea ice on primary production. In our study, we used the bulk sediment-accumulation rate, total diatom abundance, and compositional data (ice-rafted debris) to indicate whether Sites 699 and 701 are south of the PFZ or within it; increases in the bulk-accumulation rate and diatom abundance are taken to indicate a position close to or within the PFZ.

The presence of sand-sized, nonbiogenic material (icerafted debris) also plays in a role in aiding the determination of the position of the PFZ in the following manner. The biosiliceous sediments within the PFZ are diluted by ice-rafted debris because it is in this region that sediment-laden icebergs melt upon coming in contact with warmer Subantarctic Surface Waters. Icebergs calving from the ice shelves around the Weddell Sea are entrained into the Weddell Gyre and transported north to the Antarctic Convergence, whence they are transported farther east by the ACC, within which the PFZ is contained. Upon contact with the warmer waters to the north of the PFZ, the rate of iceberg melting increases, releasing solid debris frozen into the bergs or windblown (or erupted) onto their surfaces. High concentrations of ice-rafted debris are, therefore, to be expected at the northern edge of the PFZ, at least in the western part of the South Atlantic, not too far away from their source.

In the case of Hole 704B, changes in the bulk-accumulation rate and the relative interplay of carbonate and biosiliceous components were used to trace migrations of the northern boundary of the PFZ. Calcareous phytoplankton dominate the surface waters to the north, whereas biosiliceous phytoplankton are more characteristic of conditions within the PFZ, where they accumulate at high rates (N.B. Table 6). These

Table 3. Hole 704B sedimentologic and biosiliceous characteristics.

\begin{tabular}{|c|c|c|c|c|c|c|c|}
\hline \multirow[b]{2}{*}{ Unit } & \multirow[b]{2}{*}{$\begin{array}{l}\text { Depth } \\
\text { (mbsf) }\end{array}$} & \multirow[b]{2}{*}{ Lithology } & \multicolumn{5}{|c|}{ Total sediment } \\
\hline & & & $\begin{array}{c}\text { Carbonate } \\
(\%)\end{array}$ & $\begin{array}{c}\text { Organic } \\
\text { carbon } \\
(\%)\end{array}$ & $\begin{array}{l}\text { Diatoms } \\
\text { (log } \\
\mathrm{g} / \text { sediment) }\end{array}$ & $\begin{array}{c}\text { Radiolarians } \\
(\%)\end{array}$ & $\begin{array}{c}\text { Silicoflagellates } \\
(\%)\end{array}$ \\
\hline $1 \mathrm{~A}$ & $0-6$ & Highly variable & 60 & 0.3 & 7.75 & 0.9 & 1.8 \\
\hline 1B & $6-8.2$ & Nannofossil ooze & 80 & 0.5 & 6.6 & 1.5 & 0.5 \\
\hline $1 \mathrm{C}$ & $8.2-10$ & Diatom ooze & 12 & 0.4 & 8.15 & 1.9 & 0.4 \\
\hline ID & $10-14.4$ & Mixed & 40 & 0.5 & 8.0 & 1.1 & 0.5 \\
\hline $2 \mathrm{~A}$ & $16.5-26$ & $\begin{array}{l}\text { Alternating } \\
\text { siliceous/calcareous }\end{array}$ & 49 & 0.2 & 7.17 & 0.9 & 2.8 \\
\hline 2B & $26-31.7$ & Mixed & 48 & 0.2 & 7.68 & 0.5 & 3.7 \\
\hline $2 \mathrm{C}$ & $31.7-36$ & $\begin{array}{l}\text { Alternating } \\
\text { siliceous/calcareous }\end{array}$ & 50 & 0.25 & 7.85 & 2.8 & 1.6 \\
\hline $2 \mathrm{D}$ & $36-44.6$ & $\begin{array}{l}\text { Variable, dominantly } \\
\text { calcareous }\end{array}$ & 52 & 0.2 & 7.6 & 1.1 & 2.5 \\
\hline $2 \mathrm{E}$ & $44.6-75.5$ & $\begin{array}{l}\text { Variable, dominantly } \\
\text { siliceous }\end{array}$ & 36 & 0.35 & 7.8 & 0.7 & 2.4 \\
\hline $2 \mathrm{~F}$ & $75.5-102$ & $\begin{array}{l}\text { Alternating } \\
\text { siliceous/calcareous }\end{array}$ & 30 & 0.2 & 7.85 & 0.5 & 8.4 \\
\hline 3 & $102-110$ & Highly variable & 63 & 0.2 & 7.6 & 0.8 & 3.9 \\
\hline
\end{tabular}


Table 1 (continued).

\begin{tabular}{ccccccccc}
\hline \multicolumn{3}{c}{ Total biosiliceous fraction } & & \multicolumn{4}{c}{ Size distribution } \\
\cline { 1 - 1 } $\begin{array}{c}\text { Diatoms } \\
\text { (log g/sediment) }\end{array}$ & $\begin{array}{c}\text { Radiolarians } \\
(\%)\end{array}$ & $\begin{array}{c}\text { Silicoflagellates } \\
(\%)\end{array}$ & $\begin{array}{c}\text { Organic carbon } \\
(\%)\end{array}$ & $\begin{array}{c}\text { Sand } \\
(\%)\end{array}$ & $\begin{array}{c}\text { Silt } \\
(\%)\end{array}$ & $\begin{array}{c}\text { Clay } \\
(\%)\end{array}$ & Silt/clay \\
\hline 8.05 & 0.2 & 1.1 & 0.24 & 10 & 54 & 36 & 1.5 \\
7.55 & 0.4 & 1.1 & & 0.12 & 12 & 58 & 30 & 2.2 \\
7.47 & 0.4 & 1.55 & 0.12 & 11 & 50 & 39 & 1.4 \\
7.9 & 0.3 & 2.7 & 0.04 & 12 & 48 & 40 & 1.3 \\
\hline
\end{tabular}

Table 2 (continued).

\begin{tabular}{ccccccccc}
\hline \multicolumn{3}{c}{ Total biosiliceous fraction } & & \multicolumn{4}{c}{ Size distribution } \\
\cline { 1 - 1 } $\begin{array}{c}\text { Diatoms } \\
\text { (log g/sediment })\end{array}$ & $\begin{array}{c}\text { Radiolarians } \\
(\%)\end{array}$ & $\begin{array}{c}\text { Silicoflagellates } \\
(\%)\end{array}$ & $\begin{array}{c}\text { Organic carbon } \\
(\%)\end{array}$ & $\begin{array}{c}\text { Sand } \\
(\%)\end{array}$ & $\begin{array}{c}\text { Silt } \\
(\%)\end{array}$ & $\begin{array}{c}\text { Clay } \\
(\%)\end{array}$ & Silt/clay \\
\hline 8.14 & 0.12 & 0.89 & 0.39 & 9 & 51 & 40 & 1.4 \\
8.21 & 0.06 & 0.75 & & 0.4 & 14 & 52 & 34 & 1.6 \\
7.86 & 0.35 & 0.98 & 0.34 & 12 & 54 & 34 & 1.8 \\
7.66 & 0.28 & 3.02 & 0.23 & 8 & 53 & 38 & 1.6 \\
\hline
\end{tabular}

high accumulation rates also ensure the rapid preservation of calcareous components. Thus, accumulation rates in the mixed lithology are higher than those in the purer lithology. Pure diatom ooze (e.g., subunit 1C) accumulates when the southern part of the PFZ is over Site 704 and the northern border at some distance from it; pure calcareous oozes (e.g., subunit 1B) accumulate when the PFZ is well to the south of the drill site and warmer, less productive Subantarctic Surface Water overlies it.

The nonbiogenic components in Hole 704B are noticeably very minor compared with those in Holes $699 \mathrm{~A}$ and $701 \mathrm{C}$. This site, on the Meteor Rise, is far away from terrigenous sources on land, and its elevated position protects it from debris transported by gravity movement or bottom-water masses. Also, it is far from the Weddell Sea source of sediment-containing icebergs, most of which melt before reaching the Meteor Rise area. Terrigenous and ashy nonbiogenic components in these sediments must, therefore, be transported by a combination of wind and icebergs.
Additionally, variations in the abundance of Genus et species indet. 1 Fenner (this volume) also proved helpful in determining the direction of movement of the PFZ apart from changes in $\mathrm{CaCO}_{3}$ content and the abundance of diatoms and ice-rafted debris.

On the basis of a correlation made in Hole 704B, where the $\mathrm{CaCO}_{3}$ content of the sediment is a clear criterium for whether the PFZ has shifted north or south of the site, we have interpreted the abundance fluctuations of the main siliceous microfossil groups in terms of deposition below Subantarctic Surface Water, the PFZ, or AASW. Although some of these microfossil groups do not provide a simple correlation, the Genus et species indet. 1 Fenner (this volume) group did.

Genus et species indet. 1 Fenner (this volume) seems to be restricted in occurrence to sediments accumulating below the northern PFZ. These microfossils are probably the siliceous cysts of choanoflagellates, according to Silver et al. (1980), and have been reported in plankton hauls in the equatorial Pacific, as well as in the Weddell Sea and the Gulf of Alaska.

Table 3 (continued).

\begin{tabular}{|c|c|c|c|c|c|c|c|c|c|}
\hline \multicolumn{6}{|c|}{ Sand fraction } & \multicolumn{4}{|c|}{ Size distribution } \\
\hline $\begin{array}{c}\text { Biocarbonate } \\
\text { (relative \%) }\end{array}$ & $\begin{array}{c}\text { Foraminifer } \\
\text { preservation } \\
\text { index }\end{array}$ & $\begin{array}{l}\text { Biosiliceous } \\
\text { (relative \%) }\end{array}$ & $\begin{array}{l}\text { Radiolarians } \\
\text { (relative \%) }\end{array}$ & $\begin{array}{c}\text { Diatoms } \\
\text { (relative \%) }\end{array}$ & $\begin{array}{r}\text { Nonbiogenic } \\
\text { (relative \%) }\end{array}$ & $\begin{array}{l}\text { Sand } \\
(\%)\end{array}$ & $\begin{array}{l}\text { Silt } \\
(\%)\end{array}$ & $\begin{array}{l}\text { Clay } \\
(\%)\end{array}$ & Silt/clay \\
\hline 12 & 4 & 18 & 18 & 0 & 2.8 & 32 & 49 & 19 & 3.1 \\
\hline 10 & 12 & 5 & 5 & 0 & 0.4 & 14 & 58 & 28 & 0.8 \\
\hline 0 & 0.5 & 5 & 5 & 0 & 0.4 & 4 & 60 & 36 & 1.9 \\
\hline 0 & 0.5 & 5 & 5 & 0 & 0.8 & 6 & 81 & 13 & 5.6 \\
\hline 4 & 0.5 & 6 & 4 & 2 & 0.4 & 11 & 66 & 23 & 7.3 \\
\hline 8 & 0.5 & 7 & 4 & 3 & 0.4 & 19 & 68 & 13 & 8.6 \\
\hline 14 & 4.8 & 10 & 9 & 1 & 0.5 & 30 & 58 & 12 & 3.7 \\
\hline 10 & 1.9 & 10 & 8 & 2 & 1.1 & 20 & 51 & 19 & 4.1 \\
\hline 3 & 1.5 & 6 & 3 & 3 & 0.1 & 9 & 74 & 17 & 5.5 \\
\hline 2 & 0 & 3 & 1.5 & 1.5 & 0 & 5 & 80 & 15 & 5.5 \\
\hline 4 & 1 & 5 & 4 & 1 & 0.1 & 9 & 72 & 19 & 4.2 \\
\hline
\end{tabular}


Table 4. Hole 699A sedimentation and bulk-accumulation rates.

\begin{tabular}{|c|c|c|c|c|c|c|c|c|c|}
\hline \multirow[b]{3}{*}{ Unit } & \multirow[b]{3}{*}{$\begin{array}{l}\text { Depth } \\
\text { (mbsf) }\end{array}$} & \multirow{3}{*}{$\begin{array}{c}\text { Dry-bulk } \\
\text { density } \\
\left(\mathrm{g} / \mathrm{cm}^{3}\right)\end{array}$} & \multirow[b]{3}{*}{$\begin{array}{l}\text { Sedimentation rate } \\
(\mathrm{cm} / 1000 \mathrm{yr})\end{array}$} & \multicolumn{6}{|c|}{ Accumulation rate $\left(\mathrm{g} / \mathrm{cm}^{2} / 1000 \mathrm{yr}\right)$} \\
\hline & & & & \multirow[b]{2}{*}{$\begin{array}{c}\text { Bulk } \\
\text { sediment }\end{array}$} & \multirow{2}{*}{$\begin{array}{c}\text { Organic } \\
\text { carbon } \\
(\times 1000)\end{array}$} & \multicolumn{4}{|c|}{ Sand fraction components $(\times 100)$} \\
\hline & & & & & & Biosiliceous & Radiolarians & Diatoms & $\begin{array}{l}\text { Terrigenous/ } \\
\text { volcanic ash }\end{array}$ \\
\hline 1 & $0-9.6$ & 0.44 & $2.0-2.4$ & $0.88-1.08$ & $2.1-2.6$ & $6.1-7.5$ & $2.8-3.5$ & $3.0-3.7$ & $2.8-3.5$ \\
\hline 2 & $9.6-40.6$ & 0.69 & 1.23 & 0.85 & & & & & \\
\hline $2 \mathrm{~A}$ & $9.6-15$ & 0.64 & 1.64 & 1.05 & 1.3 & 7.5 & 2.3 & 5.2 & 4.3 \\
\hline 2B & $18-24$ & 0.71 & $1.3-1.4$ & 0.95 & 1.7 & 6.6 & 4.9 & 1.7 & 5.5 \\
\hline $2 \mathrm{C}$ & $28-34$ & 0.70 & $1.2-1.5$ & $0.83-1.04$ & $1.7-2.0$ & $3.7-4.7$ & $3.6-4.5$ & $0.1-0.2$ & $3.9-4.9$ \\
\hline 3 & $34-44$ & 0.67 & 1.2 & 0.80 & & & & & \\
\hline $3 \mathrm{~A}$ & $34-37.5$ & 0.73 & 1.2 & 0.88 & 1.8 & 6.2 & 3.2 & 3.0 & 5.3 \\
\hline 3B & $37.5-39.5$ & 0.58 & 1.2 & 0.70 & 1.3 & 5.9 & 2.2 & 3.7 & 2.4 \\
\hline
\end{tabular}

Table 5. Hole 701C sedimentation and bulk-accumulation rates.

\begin{tabular}{|c|c|c|c|c|c|c|c|c|c|}
\hline \multirow[b]{3}{*}{ Unit } & \multirow[b]{3}{*}{$\begin{array}{l}\text { Depth } \\
\text { (mbsf) }\end{array}$} & \multirow{3}{*}{$\begin{array}{l}\text { Dry-bulk } \\
\text { density } \\
\left(\mathrm{g} / \mathrm{cm}^{3}\right)\end{array}$} & \multirow[b]{3}{*}{$\begin{array}{l}\text { Sedimentation rate } \\
(\mathrm{cm} / 1000 \mathrm{yr})\end{array}$} & \multicolumn{6}{|c|}{ Accumulation rate $\left(\mathrm{g} / \mathrm{cm}^{2} / 1000 \mathrm{yr}\right)$} \\
\hline & & & & \multirow[b]{2}{*}{$\begin{array}{c}\text { Bulk } \\
\text { sediment }\end{array}$} & \multirow{2}{*}{$\begin{array}{c}\text { Organic } \\
\text { carbon } \\
(\times 1000)\end{array}$} & \multicolumn{4}{|c|}{ Sand fraction components $(\times 100)$} \\
\hline & & & & & & Biosiliceous & Radiolarians & Diatoms & $\begin{array}{l}\text { Terrigenous/ } \\
\text { volcanic ash }\end{array}$ \\
\hline 1 & $0-7$ & 0.36 & $2.5-3.0$ & $0.9-1.08$ & $3.5-4.2$ & $5.2-6.3$ & $3.3-4.0$ & $1.9-2.3$ & $2.8-3.3$ \\
\hline 2 & $7-52.6$ & 0.44 & $2.68-2.75$ & $1.18-1.21$ & $7-52.6$ & & & & \\
\hline $2 \mathrm{~A}$ & $7-22$ & 0.43 & 3.75 & 1.61 & 6.4 & 11.9 & 8.4 & 3.7 & 10.8 \\
\hline $2 \mathrm{~B}$ & $22-33$ & 0.31 & $1.8-2.2$ & $0.56-0.68$ & $1.9-2.3$ & $4.9-6.0$ & $1.7-2.1$ & $3.2-3.9$ & $2.4-2.9$ \\
\hline $2 \mathrm{C}$ & $33-52.6$ & 0.51 & $2.45-2.93$ & $1.25-1.45$ & $2.9-3.4$ & $5.5-6.6$ & $4.9-5.8$ & $0.6-0.7$ & $4.3-5.1$ \\
\hline
\end{tabular}

The fact that this group is more common in the shallower Hole $704 \mathrm{~B}(2532 \mathrm{~m})$ than in the two deeper holes is probably due to dissolution in the water column, as well as on the sediment surface (sediment-accumulation rates at these sites are much lower than at Site 704), and, in part, to different ecologic conditions, as Sites 699 and 701 are less often below the northern boundary of the PFZ than Site 704.

In all of the holes, endoskeletal dinoflagellates belonging to the genus Actiniscus, among which the most common species is Actiniscus pentaradiatus, are the most common in sediments that were deposited below Antarctic PFZ Surface Waters (Figs. 6C, 7C, and $8 \mathrm{C}$ ). However, further study is necessary to determine whether there really is a correlation with surface-water masses.

The relationships determined for Hole 704B were applied to Holes $699 \mathrm{~A}$ and $701 \mathrm{C}$, where the absence of $\mathrm{CaCO}_{3}$ made interpretation of the PFZ position on the basis of decreased diatom abundance difficult. In fact, the conclusions reached using the microfossil groups agreed well with those based on the abundance of ice-rafted debris.
We have summarized the relative wanderings of the PFZ with respect to the three drill sites for the last $2 \mathrm{~m}$.y. in Figure 9.

\section{Hole 699A: Western South Atlantic}

Diatomaceous lithology in the upper Gilbert indicates that the surface waters of the PFZ were over Site 699 . There appears to have been some fluctuation in the position of the PFZ in the early Gauss, as indicated by the variable accumulation rates among subunits $2 \mathrm{C}, 3 \mathrm{~A}$, and $3 \mathrm{~B}$, but the overall trend in the PFZ position is migration northward. The most northerly PFZ location was reached in the middle to late Gauss ( $\sim 2.96$ to $\sim 2.4$ m.y.). The Matuyama is characterized by a gradual southward migration of the PFZ, as documented by increasing bulk-accumulation rates that reflect the appearance of increasingly productive surface waters overhead, as well as by an increase in the abundance of ice-rafted debris. The presence of minor amounts of $\mathrm{CaCO}_{3}$ in transitional subunit 2A (approximately $1.04 \mathrm{~m} . \mathrm{y}$.) may possibly indicate that a sharp fluctuation brought the northern border of the

Table 6. Hole 704C sedimentation and bulk-accumulation rates.

\begin{tabular}{|c|c|c|c|c|c|c|c|c|c|c|c|}
\hline \multirow[b]{3}{*}{ Unit } & \multirow[b]{3}{*}{$\begin{array}{l}\text { Depth } \\
\text { (mbsf) }\end{array}$} & \multirow{3}{*}{$\begin{array}{l}\text { Dry-bulk } \\
\text { density } \\
\left(\mathrm{g} / \mathrm{cm}^{3}\right)\end{array}$} & \multirow{3}{*}{$\begin{array}{l}\text { Sedimentation } \\
\text { rate }(\mathrm{cm} / 1000 \\
\mathrm{yr})\end{array}$} & \multicolumn{8}{|c|}{ Accumulation rate $\left(\mathrm{g} / \mathrm{cm}^{2} / 1000 \mathrm{yr}\right)$} \\
\hline & & & & \multirow[b]{2}{*}{$\begin{array}{c}\text { Bulk } \\
\text { sediment }\end{array}$} & \multirow{2}{*}{$\begin{array}{l}\text { Organic } \\
\text { carbon } \\
(\times 1000)\end{array}$} & \multirow[b]{2}{*}{$\mathrm{CaCO}_{3}$} & \multicolumn{5}{|c|}{ Sand fraction components $(\times 100)$} \\
\hline & & & & & & & Biocarbonate & Biosiliceous & Radiolarians & Diatoms & $\begin{array}{l}\text { Terrigenous/ } \\
\text { volcanic ash }\end{array}$ \\
\hline 1 & $0-14.5$ & 0.58 & 2.3 & 1.33 & & & & & & & \\
\hline $1 \mathrm{~A}$ & $0-6$ & 0.46 & 2.0 & 0.92 & 2.8 & 0.55 & 0.11 & 0.17 & 0.17 & 0 & 0.02 \\
\hline 1B & $6-8.2$ & $? 0.4$ & 2.2 & 0.88 & 4.4 & 0.7 & 0.08 & 0.04 & 0.04 & 0 & 0.0004 \\
\hline $1 \mathrm{C}$ & $8.2-10$ & 0.52 & 3.6 & 1.87 & 7.5 & 0.22 & 0 & 0.09 & 0.09 & 0 & 0.0007 \\
\hline $1 \mathrm{D}$ & $10-14.5$ & 0.44 & 3.85 & 1.69 & 8.5 & 0.68 & 0 & 0.08 & 0.08 & 0 & 0.013 \\
\hline 2 & $16.5-102$ & 0.48 & 8.7 & 4.18 & & & & & & & \\
\hline $2 \mathrm{~A}$ & $16.5-26$ & 0.55 & 9.5 & 5.32 & 10.5 & 2.56 & 0.43 & 0.38 & 0.21 & 0.16 & 0.022 \\
\hline $2 \mathrm{~B}$ & $26-31.7$ & 0.57 & 9.5 & 5.42 & 10.8 & 2.6 & 0.57 & 0.41 & 0.37 & 0.04 & 0.02 \\
\hline $2 \mathrm{C}$ & $31.7-36$ & $? 0.57$ & 7.17 & 4.09 & 10.2 & 2.0 & & & & & \\
\hline $2 \mathrm{D}$ & $36-44.6$ & $? 0.57$ & $3.19-4.3$ & $1.82-2.45$ & $3.6-4.9$ & $0.95-1.27$ & $0.18-0.25$ & $0.18-0.25$ & $0.15-0.20$ & $0.03-0.05$ & $0.025-0.018$ \\
\hline $2 \mathrm{E}$ & $44.6-75.5$ & 0.48 & 7.0 & 3.36 & 11.8 & 1.21 & 0.1 & 0.2 & 0.1 & 0.1 & 0 \\
\hline $2 \mathrm{~F}$ & $75.5-102$ & 0.45 & $6.97-8.55$ & $3.14-3.85$ & $6.3-7.7$ & $0.94-1.16$ & $0.06-0.08$ & $0.09-0.12$ & $0.04-0.06$ & $0.04-0.06$ & 0 \\
\hline
\end{tabular}



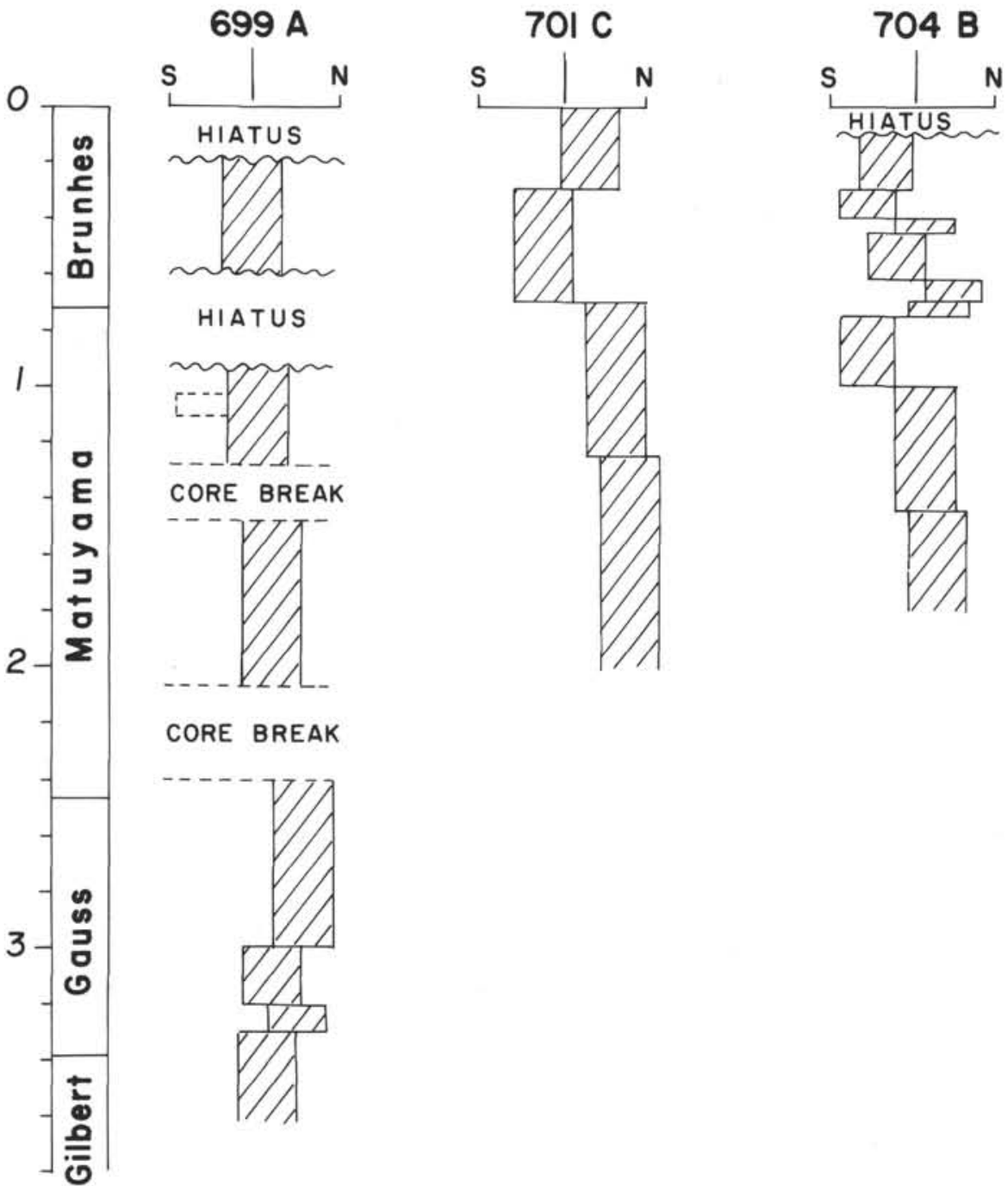

Figure 9. PFZ migration curves based on the accumulation rates of bulk sediment and ice-rafted debris (including calcareous and siliceous microfossil accumulation rates for Hole 704B) and changes in the abundance of diatoms, Actiniscus spp., and Genus et species indet. 1 Fenner (this volume).

PFZ over Site 699 (N.B. Hole 704B also documents a sharp southerly migration at roughly the same period; Fig. 9).

A hiatus spanning the period from 1.0 to $0.6 \mathrm{~m}$.y. cuts out the uppermost Matuyama and lower Brunhes section in Hole 699A. Above this hiatus, the higher diatom abundance and moderately high bulk-accumulation rates show that Site 699 lay beneath the PFZ. The uniformity of the whole middle to upper Brunhes section suggests that conditions in the overlying waters were fairly stable within this time period. However, this is inconsistent with the middle to upper Brunhes sediments in Holes 701C and 704B, which show migration of the PFZ. For instance, the southerly migration identified in Hole $701 \mathrm{C}$, which started at about $0.8 \mathrm{~m} . \mathrm{y}$. and lasted until about 0.4 m.y., does not appear in Hole 699A because the sediments deposited during this period were removed by a hiatus.

\section{Hole 701C: Western South Atlantic}

The investigated record in Hole $701 \mathrm{C}$ begins in the Matuyama. Low diatom abundance coupled with low bulkaccumulation rates and an ashy/clayey diatom ooze lithology indicate that Site 701 lay south of the PFZ (Fig. 9), although there appears to have been a very gradual southward migration throughout the Matuyama.

Diatom abundance is high and bulk-accumulation rates are slightly higher in the uppermost Matuyama-lowermost Brunhes than in the sediments below. On this basis we have interpreted a marked southward migration of the PFZ, during which Site 701 was frequently beneath the PFZ during the time interval 0.4-0.8 m.y. In contrast, more stable conditions seem to have existed during the latter part of the Brunhes (about $0.4 \mathrm{~m} . \mathrm{y}$. to the Holocene), when, once again, decreased accumulation rates and a decrease in diatom abundance signify that the PFZ had migrated north of Site 701 .

\section{Hole 704B: Eastern South Atlantic}

The high sediment-accumulation rate at Site 704 , which is due primarily to the preservation of $\mathrm{CaCO}_{3}$, has provided us with a detailed record of PFZ migrations for the investigated Brunhes-Matuyama period. Whereas Sites 699 and 701 recorded migrations of the southern boundary of the PFZ, Site 704 recorded predominantly migrations of the northern boundary (Fig. 9). 
The lower part of the record investigated in Hole 704B shows that during early Matuyama times the PFZ was positioned over Site 704. Small variations in diatom and $\mathrm{CaCO}_{3}$ content indicate that this northern boundary fluctuated on a fine scale. A dramatic increase in diatom abundance at about $1.74 \mathrm{~m} . \mathrm{y}$. (base of subunit $2 \mathrm{~F}$ ) and relatively high accumulation rates document a sharp northerly shift of the PFZ, which brought it well over Site 704. With the exception of a couple of major excursions toward the south that resulted in a calcareous lithology between about $1.56-1.60$ and $1.63-1.8 \mathrm{~m} . \mathrm{y}$. , the northern boundary of the PFZ stayed well north of Site 704 for much of the middle Matuyama, although the decrease in diatom abundance toward the overlying subunit $2 \mathrm{E}$ indicates a gradual southward movement of the PFZ. This trend continued throughout the rest of the Matuyama into the early Brunhes, apart from a slight northward shift indicated between the top of the Matuyama and the bottom of the Brunhes $(0.75-0.63$ m.y.). The middle Brunhes period documents sharp fluctuations in the northern boundary of the PFZ, especially between 0.45 and $0.3 \mathrm{~m}$.y. Superimposed upon these sharp fluctuations the overall northerly migration of the PFZ seen in Hole 701C during the middle Brunhes is also apparent in Hole 704B.

\section{Polar Front Zone Migrations and Paleoceanographic Conditions in the Pliocene-Holocene South Atlantic}

The middle to late Matuyama period documents a gradual southward migration of the PFZ that was apparently accompanied by an intensification of bottom-water activity, which resulted in the erosion of upper Matuyama sediments (1.50.96 m.y.) at Site 699 . We observed some evidence of winnowing, such as low organic carbon contents with generally high sand contents and peaks in the fraction of nonbiogenic ice-rafted debris as well as sporadic occurrences of reworked diatoms, throughout the Brunhes at Site 704.

As noted in the "Introduction" section, sediment deposition at the deepest site $(701 ; 4647 \mathrm{~m})$ is influenced by AABW. The upper reaches of AABW may also exert some control on sedimentation at Site 699 , which is almost $1000 \mathrm{~m}$ shallower $(3716 \mathrm{~m})$, but the deep-reaching ACC and entrained CPDW probably have more control on sedimentation at this site. In contrast, Site 704 on the Meteor Rise is too shallow to fall under the influence of $\mathrm{AABW}$, and thus the ACC, together with CPDW, exerts the strongest influence on sedimentation in this region.

The correlation of the latest Matuyama-earliest Brunhes hiatus in Hole 699A with possible winnowing events in the shallower Hole 704B suggests that the period younger than 1.0 m.y. was marked by an intensification of velocities within the ACC and CPDW. Late Matuyama/early Brunhes hiatuses are also recorded in cores from either side of the Southwest Indian Ridge at depths below $4000 \mathrm{~m}$ (Westall and Fenner, in press). A study in the Southeast Atlantic Ocean (Ledbetter and Ciesielski, 1982) also interpreted increased velocities within $\mathrm{AABW}$, but not for the shallower water masses. This study focused on erosional events on the southern flank of the Southwest Indian Ridge that spanned the lower to middle Pleistocene. The sediment records of Holes 699A and 704B show that erosion and winnowing occurred during the period when the PFZ was moving south. The top of the hiatus, in fact, coincides with the most southerly position of the PFZ in the Matuyama. Site 704 was located north of the northern PFZ boundary and north of the main axis of the ACC (Fig. 2B), as suggested by the winnowed sediments; current velocities, while high enough to cause reworking, were apparently not high enough to cause significant erosion.
Ciesielski and Grinstead (1986) and Ledbetter and Ciesielski (1986) interpreted a gradual long-term increase in production of $\mathrm{AABW}$ and a simultaneous intensification of CPDW and an increase in ACC velocity between about 2.7 and 1.0 m.y., which led to the widespread development of shallow and deep hiatuses. The late Gauss/early Matuyama expansion of polar waters around Antarctica apparently preceded the period of greatest growth of the Northern Hemisphere ice sheets (Ciesielski and Grinstead, 1986), but the increase in AABW production and in the intensity of CPDW and ACC during the Matuyama may well be related to Northern Hemisphere glaciation, which commenced about $2.4 \mathrm{~m} . \mathrm{y}$.

In conjunction with increased ACC velocities and intensification of the CPDW in the early Brunhes, there is a marked change in the climatic signal as recorded in deep-sea sediments throughout the Southern Ocean (Keany and Kennett, 1972; Ledbetter and Ciesielski, 1986; Osborn et al., 1983; Westall and Fenner, in press). In contrast to the relatively stable, low-frequency conditions of the PFZ that characterized the Matuyama period, the Brunhes is generally distinguished by high-frequency fluctuations of the climatic signal that were caused by glacial and interglacial alternations. This is especially noticeable in Hole 704B, where the pronounced lithologic alternations between siliceous and calcareous sediments marking fluctuations in the northern boundary of the PFZ are clearly evident. Even at Site 701 some fluctuation of the southern margin of the PFZ is recorded.

There have been a number of studies of the glacial/ interglacial fluctuations in the Brunhes period and their effects on the PFZ in the Southern Ocean. Hole 704B documents strong displacements of the northern PFZ border in the southeast Atlantic Ocean, whereas migrations of the southern border do not appear to have been so frequent. Burckle (1984) identified large differences in the amount of migration between the northern and the southern PFZ boundaries during the last glacial maximum, in which the southern border apparently shifted $8^{\circ}$ north whereas the northern border migrated only $3^{\circ}$ (thus leading to a narrower PFZ). Similarly, Hays et al. (1976) deduced a $7^{\circ}$ northerly shift for the PFZ in the South Atlantic/ Southwest Indian Ocean region. As mentioned previously, oceanographic systems are complex and interactive (the oceanographic teleconnections of Johnson, 1985) and glacial/ interglacial fluctuations in the PFZ could, therefore, be affected by other factors, such as the position and intensity of the Weddell Gyre, as well as the northward expansion of sea ice and polar waters. This is documented by Burckle and Burak's (1988) study of the influence of the Weddell Gyre during the late Quaternary, in which they postulated that the Weddell Gyre imposes a stronger east-west component to fluctuations in the position of the PFZ than the traditionally accepted north-south movements.

The erosion of the last $100,000 \mathrm{yr}$ of sediments on the crest of the Meteor Rise (Fenner, this volume) may be evidence of increased velocities of $\mathrm{ACC} / \mathrm{CPDW}$ during the late Brunhes. There does not appear to have been significant erosion by bottom waters, such as AABW, in the vicinity of Site 701 in the western South Atlantic. The inferred lack of surface sediment at Site 699 could be due in part to coring, but it certainly reflects erosion by the deep-reaching ACC/CPDW.

\section{CONCLUSIONS}

This study has demonstrated the usefulness of detailed paleontologic and sedimentologic studies in unraveling the oceanographic record for much of the last $4 \mathrm{~m}$.y. By using changes in sediment composition (microfossils and ice-rafted debris, in particular), grain size, and bulk sediment-accumu- 
lation rates we have traced migrations of the PFZ in the South Atlantic during this period. The location of the PFZ over Sites 699 and 701 in the western South Atlantic is indicated in our data by relatively high bulk sediment-accumulation rates and relatively high diatom contents due to high phytoplankton production in the surface waters of the PFZ. Additionally, increases in the accumulation rates of sand-sized, nonbiogenic ice-rafted debris occur because of iceberg melting in this zone.

To the east, the preservation of carbonate at the shallower Site 704 , on the Meteor Rise, has resulted in very high bulk sediment-accumulation rates. At this site north of the presentday PFZ, fluctuations in the northern border of the PFZ have been traced by the interplay of diatomaceous (deposited when the PFZ was over Site 704) and calcareous (deposited when the PFZ was south of the site) lithology and, consequently, by changes in the bulk-accumulation rates, with higher rates indicating a northerly PFZ position over Site 704 .

The resulting history of the PFZ was documented as follows.

$$
\sim 3.8 \text { to } \sim 2.4 \text { m.y. }
$$

Sediments in Hole 699 indicate that the PFZ had a southerly position during the Gilbert, but fluctuated during the early Gauss and migrated north of Site 699 in the late Gauss.

$$
\sim 2.0 \text { to } \sim 0.75 \text { m.y. }
$$

All cores record a gradual reversal of this trend throughout the Matuyama, as indicated by the gradually increasing bulk sediment-accumulation rates and diatom abundances in Holes $699 \mathrm{~A}$ and $701 \mathrm{C}$, coupled with increasing accumulation rates and $\mathrm{CaCO}_{3}$ content in Hole 704B. During late Matuyama times, the PFZ was positioned over or occasionally north of Sites 699 and 701. Its northern border apparently strongly fluctuated over Site 704. Southerly excursions of the PFZ throughout the late Matuyama are recorded by the calcareous lithology in Hole 704B (and possibly in Hole 699A).

The acme of the southerly PFZ migration in the late Matuyama appears to have been accompanied by an intensified circulation at shallow and intermediate depths, which resulted in erosion at Site $699(1.0-0.6 \mathrm{~m} . \mathrm{y}$.) and winnowing at Site 704. This was probably due to increased ACC velocities.

\section{$\sim 0.75$ m.y. to the Holocene}

Strong fluctuations in the position of the northern border of the PFZ are recorded in Hole 704B, especially between 0.3 and $0.45 \mathrm{~m} . \mathrm{y}$. in the middle Brunhes. This is also seen in the fluctuating lithology in Hole $701 \mathrm{C}$ and, to a lesser extent because of sediment removal by hiatuses, in Hole 699A.

\section{ACKNOWLEDGMENTS}

This study was generously financed through Deutsche Forschungsgemeinschaft Grants Sa 207/29-2 and 3, and Fu 119/13-1. We thank S. Peter and G. Seiffert for their laboratory help, F. Rudolph, who aided the microscope analyses, and Alain Cossart for drafting the diagrams. We are very grateful to S. Rossi, S. Wise, T. Moore, Y. Kristoffersen, and an unnamed reviewer, whose helpful comments improved the manuscript.

\section{REFERENCES}

Burckle, L. H., 1984. Diatom distribution and palaeoceanographic reconstruction in the Southern Ocean-present and Last Glacial Maximum. Mar. Micropaleontol., 9:241-261.

Burckle, L. H., and Burak, R. W., 1988. Fluctuations in late Quaternary diatom abundances: stratigraphic and paleoclimatic implications from subantarctic deep sea cores. Palaeogeogr., Palaeoclimatol., Palaeoecol., 67:147-156.
Burckle, L. H., and Cirilli, J., 1987. Origin of diatom ooze belt in the Southern Ocean: implications for late Quaternary paleoceanography. Micropaleontology, 33:82-86.

Ciesielski, P. F., and Grinstead, G. P., 1986. Pliocene variations in the position of the Antarctic Convergence in the southeast Atlantic. Paleoceanography, 1:197-232.

Ciesielski, P. F., Kristoffersen, Y., et al., 1988. Proc. ODP, Init. Repts., 114: College Station, TX (Ocean Drilling Program).

Dean, W. E., Leinen, M., and Stow, D.A.V., 1984. Classification of deep-sea, fine grained sediments. J. Sediment. Petrol., 55:250256.

Goodell, H. G., 1973. The sediments. In Goodell, H. G. (Ed.), Marine Sediments of the Southern Oceans. Antarct. Map Folio Ser., 17.

Gordon, A. L., 1967. Structure of Antarctic Waters between $20^{\circ} \mathrm{W}$ and $170^{\circ}$ W. In Bushnell, V. C. (Ed.), Antarct. Map Folio Ser., 6. 1971. Antarctic Polar Front Zone. In Reid, J. (Ed.), Antarctic Oceanology I. Am. Geophys. Union, Antarct. Res. Ser., 15:169-203.

Hays, J. D., Lozano, J. A., Shackleton, N. J., and Irving, G., 1976. Reconstruction of the Atlantic and western Indian Ocean sectors of the 18,000 B. P. Antarctic Ocean. In Cline, R. M., and Hays, J. D. (Eds.), Investigations of Late Quaternary Paleoceanography and Paleoclimatology: Mem. Geol. Soc. Am., 145:337-372.

Hellmer, H., Bersch, M., Augstein, E., and Grabermann, I., 1985. The Southern Ocean: A Survey of Oceanographic and Marine Meteorological Research Work. Ber. Polarforschung, 26.

Johnson, D. A., 1985. Abyssal teleconnections II. Initiation of Antarctic Bottom Water flow in the southwest Atlantic. In Hsü, K. J., and Weissert, H. J. (Eds.), South Atlantic Paleoceanography: Cambridge (Cambridge Univ. Press), 243-281.

Keany, J., and Kennett, J. P., 1972. Pliocene-early Pleistocene palaeoclimatic history recorded in antarctic-subantarctic deep-sea cores. Deep-Sea Res., Part A, 19:529-548.

Ledbetter, M. T., and Ciesielski, P. F., 1982. Bottom-current erosion in the South Atlantic sector of the Southern Ocean. Mar. Geol., 46:329-341.

1986. Post-Miocene disconformities and paleoceanography in the Atlantic sector of the Southern Ocean. Mar. Geol., 52:185214.

Lisitzin, A. P., 1971. Distribution of siliceous microfossils in suspension and bottom sediments. In Funnell, B. M., and Riedel, W. R. (Eds.), The Micropalaeontology of the Oceans: Cambridge (Cambridge Univ. Press), 173-195.

Lutjeharms, J.R.E., 1985. Location of frontal systems between Africa and Antarctica: some preliminary results. Deep-Sea Res., Part A, 32:1499-1509.

Lutjeharms, J.R.E., Walters, N. M., and Allanson, B. R., 1985. Oceanic frontal systems and biological enhancement. In Siegfried, W. R., Condy, P. R., and Laws, R. M. (Eds.), Antarctic Nutrient Cycles and Food Webs, 11-21.

Osborn, N. I., Ciesielski, P. F., and Ledbetter, M. T., 1983. Disconformities and paleoceanography in the Southeast Indian Ocean during the past 5.4 million years. Geol. Soc. Am. Bull., 94:13451358.

Silver, M. D., Mitchell, J. G., and Ringo, D. L., 1980. Siliceous nannoplankton, II. Newly discovered cysts and abundant choanoflagellates from the Weddell Sea, Antarctica. Mar. Biol., $58: 211-217$.

van Bennekom, A. J., Berger, G. W., van der Gaast, S. J., and de Vries, R.T.P., 1988. Primary productivity and the silica cycle in the Southern Ocean (Atlantic Sector). Palaeogeogr., Palaeoclimatol., Palaeoecol., 67:19-30.

Westall, F., and Fenner, J., in press. Polar Front fluctuations and the Matuyama/Brunhes palaeoceanographic record in the SE Atlantic. NATOIASI Proc., Geol. Hist. Polar Oceans: Arctic versus Antarctic.

Wyrtki, K., 1960. The Antarctic Circumpolar Current and the Antarctic Polar Front. Dtsch. Hydrogr. Z., 13:153-174.

Date of initial receipt: 6 July 1989

Date of acceptance: 19 December 1989

Ms 114B-175 
APPENDIX A

Hole 699A Data

\begin{tabular}{|c|c|c|c|c|c|c|c|c|c|c|c|c|c|c|c|}
\hline \multirow[b]{2}{*}{$\begin{array}{l}\text { Core, section, } \\
\text { interval }(\mathrm{cm})\end{array}$} & \multirow[b]{2}{*}{$\begin{array}{l}\text { Depth } \\
\text { (mbsf) }\end{array}$} & \multirow[b]{2}{*}{$\begin{array}{l}\text { Sand } \\
(\%)\end{array}$} & \multirow[b]{2}{*}{$\begin{array}{l}\text { Silt } \\
(\%)\end{array}$} & \multirow[b]{2}{*}{$\begin{array}{c}\text { Clay } \\
(\%)\end{array}$} & \multirow[b]{2}{*}{$\begin{array}{l}\text { Silt/ } \\
\text { clay }\end{array}$} & \multicolumn{7}{|c|}{ Sand fraction components (relative \%) } & \multirow[b]{2}{*}{$\begin{array}{c}\text { Authigenic } \\
\text { particles } \\
(\%)\end{array}$} & \multirow[b]{2}{*}{$\begin{array}{c}\text { Organic } \\
\text { carbon } \\
(\%)\end{array}$} & \multirow[b]{2}{*}{$\begin{array}{c}\text { Car- } \\
\text { bonate } \\
(\%)\end{array}$} \\
\hline & & & & & & Diatoms & $\begin{array}{l}\text { Radio- } \\
\text { larians }\end{array}$ & $\begin{array}{l}\text { Total } \\
\text { bio- } \\
\text { siliceous }\end{array}$ & $\begin{array}{c}\text { Total } \\
\text { carbonate }\end{array}$ & Detrital & $\begin{array}{l}\text { Volcanic } \\
\text { ash }\end{array}$ & $\begin{array}{c}\text { Total } \\
\text { non- } \\
\text { biogenic }\end{array}$ & & & \\
\hline \multicolumn{16}{|l|}{ 114-699A- } \\
\hline $1 \mathrm{H}-1,25-27$ & 0.25 & 4.0 & 59.3 & 36.7 & 1.6 & 3.0 & 0.7 & 3.7 & 0 & 0.2 & 0 & 0.2 & 0.1 & 0.44 & 0.02 \\
\hline $1 \mathrm{H}-1,124-126$ & 1.24 & 4.7 & 59.0 & 36.3 & 1.6 & 3.4 & 0.8 & 4.2 & 0 & 0.5 & 0 & 0.5 & 0 & 0.37 & 0 \\
\hline $1 \mathrm{H}-2,28-30$ & 1.78 & 11.3 & 49.3 & 39.4 & 1.3 & 8.3 & 1.5 & 9.8 & 0 & 1.0 & 0.5 & 1.5 & 0 & 0.43 & 0 \\
\hline $1 \mathrm{H}-2,75-77$ & 2.25 & 7.7 & 54.0 & 38.3 & 1.4 & 5.1 & 1.0 & 6.1 & 0 & 1.0 & 0.5 & 1.5 & 0.1 & 0.44 & 0 \\
\hline $1 \mathrm{H}-2,146-148$ & 2.96 & 11.3 & 55.2 & 33.5 & 1.6 & 8.9 & 1.3 & 10.2 & 0 & 0.8 & 0.3 & 1.1 & 0 & 0.43 & 0 \\
\hline $1 \mathrm{H}-3,72-74$ & 3.72 & 11.8 & 44.2 & 44.0 & 1.0 & 0 & 2.2 & 2.2 & 0 & 5.4 & 3.7 & 9.1 & 0.5 & 0.34 & 0 \\
\hline $1 \mathrm{H}-3,124-126$ & 4.24 & 13.0 & 50.3 & 36.7 & 1.4 & 8.2 & 2.7 & 10.9 & 0 & 0.7 & 1.4 & 2.1 & 0 & 0.41 & 0 \\
\hline $1 \mathrm{H}-4,24-26$ & 4.74 & 4.7 & 66.5 & 28.8 & 2.3 & 3.6 & 1.0 & 4.6 & 0 & 0.1 & 0 & 0.1 & 0 & 0.34 & 0 \\
\hline $1 \mathrm{H}-4,126-128$ & 5.76 & 4.2 & 61.6 & 34.2 & 1.8 & 1.7 & 2.4 & 4.1 & 0 & 0.1 & 0 & 0.1 & 0 & 0.38 & 0 \\
\hline $1 \mathrm{H}-5,25-27$ & 6.25 & 6.5 & 61.6 & 31.9 & 1.9 & 4.2 & 2.2 & 6.4 & 0 & ${ }^{a} 0.1$ & & 0.1 & 0 & 0.33 & 0 \\
\hline $1 \mathrm{H}-5,75-77$ & 6.75 & 14.8 & 47.9 & 37.3 & 1.3 & 1.7 & 2.4 & 4.1 & 0 & 3.6 & 4.9 & 8.5 & 0.2 & 0.24 & 0.05 \\
\hline $1 \mathrm{H}-5,104-106$ & 7.04 & 8.8 & 52.2 & 39.0 & 1.3 & 0.8 & 4.9 & 5.7 & 0 & 1.5 & 1.6 & 3.1 & 0 & 0.37 & 0.04 \\
\hline $1 \mathrm{H}-5,135-137$ & 7.35 & 27.0 & 42.8 & 30.2 & 1.4 & 0.4 & 13.2 & 13.6 & 0 & 8.6 & 4.8 & 13.4 & 0 & 0.34 & 0.1 \\
\hline $1 \mathrm{H}-6,35-37$ & 7.85 & 12.3 & 57.4 & 30.3 & 1.9 & 1.3 & 7.1 & 8.4 & 0 & 1.9 & 1.7 & 3.6 & 0.3 & 0.43 & 0.01 \\
\hline $2 \mathrm{H}-2,35-37$ & 10.45 & 22.5 & 44.0 & 33.5 & 1.3 & 17. & 1.5 & 18.6 & 0 & 3.2 & 0.4 & 3.6 & 0.1 & & \\
\hline $2 \mathrm{H}-2,85-87$ & 10.95 & 15.4 & 44.6 & 40.0 & 1.1 & 0.3 & 2.7 & 3.0 & 0 & 7.0 & 4.7 & 11.7 & 0.7 & 0.24 & 0.12 \\
\hline $2 \mathrm{H}-3,34-36$ & 11.94 & 10.4 & 54.7 & 34.9 & 1.6 & 5.9 & 3.0 & 8.9 & 0 & 1.0 & 0.4 & 1.4 & 0.1 & 0.27 & 0.01 \\
\hline $2 \mathrm{H}-3,136-138$ & 12.96 & 3.2 & 67.9 & 28.9 & 2.3 & 2.1 & 0.6 & 2.7 & 0.3 & 0.1 & 0.1 & 0.2 & 0 & 0.32 & 19.75 \\
\hline $2 \mathrm{H}-4,42-44$ & 13.52 & 4.5 & 68.5 & 27.0 & 2.5 & 1.8 & 2.2 & 4.0 & 0 & 0.3 & 0.1 & 0.4 & 0.1 & 0.24 & 0.02 \\
\hline $2 \mathrm{H}-4,136-138$ & 14.46 & 11.6 & 51.5 & 36.9 & 1.4 & 4.2 & 2.0 & 6.2 & 0 & 2.7 & 2.2 & 4.9 & 0.5 & 0.24 & 0.01 \\
\hline $2 \mathrm{H}-5,15-17$ & 14.75 & 13.5 & 73.6 & 12.9 & 5.7 & 2.8 & 3.6 & 6.4 & 0 & 5.5 & 0.8 & 6.3 & 0.8 & 0.26 & 0.02 \\
\hline $3 \mathrm{H}-1,59-61$ & 18.69 & 21.4 & 32.1 & 46.5 & 0.7 & 3.6 & 9.4 & 13.1 & 0 & 5.5 & 1.5 & 7.0 & 0.3 & 0.23 & 0.02 \\
\hline $3 \mathrm{H}-1,144-146$ & 19.54 & 12.3 & 48.7 & 39.0 & 1.3 & 0.3 & 4.0 & 4.5 & 0 & 5.7 & 1.8 & 7.5 & 0.3 & 0.19 & 0.01 \\
\hline $3 \mathrm{H}-2,45-47$ & 20.05 & 10.1 & 46.2 & 43.7 & 1.1 & 0.4 & 5.2 & 5.7 & 0 & 3.6 & 0.4 & 4.0 & 0.4 & 0.20 & 0 \\
\hline $3 \mathrm{H}-2,85-87$ & 20.45 & 5.8 & 44.9 & 49.3 & 0.9 & 0.1 & 4.8 & 5.0 & 0 & 0 & 0.6 & 0.6 & 0.2 & 0.24 & 0.02 \\
\hline $3 \mathrm{H}-3,55-57$ & 21.69 & 9.3 & 51.6 & 38.1 & 1.4 & 0 & 3.5 & 3.5 & 0 & 3.3 & 2.0 & 5.3 & 0.5 & 0.17 & 0 \\
\hline $3 \mathrm{H}-3,104-106$ & 22.14 & 16.6 & 54.3 & 29.1 & 1.9 & 0.3 & 5.3 & 5.6 & 0 & 7.1 & 2.9 & 10.0 & 1.0 & 0.18 & 0 \\
\hline $3 \mathrm{H}-4,15-17$ & 22.75 & 20.5 & 49.3 & 30.2 & 1.6 & 2.2 & 5.7 & 7.9 & 0 & 7.4 & 3.5 & 10.9 & 1.2 & 0.19 & 0 \\
\hline $3 \mathrm{H}-4,62-64$ & 23.22 & 11.8 & 53.0 & 35.2 & 1.5 & 5.9 & 3.0 & 8.9 & 0 & 1.3 & 1.3 & 2.6 & 0.3 & 0.18 & 0 \\
\hline $4 \mathrm{H}-2,61-13$ & 29.71 & 13.3 & 61.4 & 25.3 & 2.4 & 0.5 & 8.0 & 8.5 & 0 & 2.9 & 1.3 & 4.2 & 0.6 & 0.18 & 0 \\
\hline $4 \mathrm{H}-2,109-111$ & 30.19 & 8.3 & 50.6 & 41.1 & 1.2 & 0.2 & 4.0 & 4.2 & 0 & 1.7 & 1.9 & 3.6 & 0.5 & 0.28 & 0.04 \\
\hline $4 \mathrm{H}-3,60-62$ & 31.20 & 8.1 & 46.7 & 46.2 & 1.0 & 0.1 & 3.8 & 3.9 & 0 & 1.6 & 2.0 & 3.6 & 0.6 & 0.20 & 0.01 \\
\hline $4 \mathrm{H}-3,114-116$ & 31.74 & 7.1 & 41.4 & 51.5 & 0.9 & 0 & 1.5 & 1.5 & 0 & 2.6 & 2.6 & 5.2 & 0.4 & 0.23 & 0.02 \\
\hline $4 \mathrm{H}-4,49-51$ & 32.59 & 8.6 & 63.8 & 27.6 & 2.3 & 0.1 & 3.7 & 3.8 & 0 & 1.9 & 2.7 & 4.6 & 0.2 & 0.19 & 0.02 \\
\hline $4 \mathrm{H}-4,88-90$ & 33.09 & 8.1 & 52.6 & 39.4 & 1.3 & 0 & 5.0 & 5.0 & 0 & 1.0 & 1.8 & 2.8 & 0.2 & 0.16 & 0.01 \\
\hline $4 \mathrm{H}-5,59-61$ & 34.19 & 8.3 & 49.5 & 42.2 & 1.2 & 0 & 4.4 & 4.4 & 0 & 0.9 & 2.4 & 3.3 & 0.6 & 0.15 & 0 \\
\hline $4 \mathrm{H}-5,109-111$ & 34.69 & 8.9 & 50.4 & 40.7 & 1.2 & 1.8 & 4.4 & 6.2 & 0 & 1.1 & 1.6 & 2.7 & 0 & 0.18 & 0 \\
\hline $5 \mathrm{H}-2,102-104$ & 39.12 & 13.2 & 52.7 & 34.1 & 1.5 & 3.5 & 3.6 & 7.1 & 0 & 3.8 & 2.2 & 6.0 & 0.1 & 0.20 & 0 \\
\hline $5 \mathrm{H}-3,74-76$ & 40.84 & 9.7 & 35.9 & 54.4 & 0.7 & 2.8 & 3.3 & 6.1 & 0 & 1.6 & 1.9 & 3.5 & 0.1 & 0.18 & 0 \\
\hline $5 \mathrm{H}-3,124-126$ & 41.34 & 12.9 & 39.0 & 48.1 & 0.8 & 11.7 & 0.8 & 12.0 & 0 & 0.3 & 0.5 & 0.8 & 0.1 & 0.18 & 0 \\
\hline $5 \mathrm{H}-4,75-77$ & 42.35 & 19.8 & 55.3 & 24.9 & 2.2 & 11.3 & 4.4 & 15.7 & 0 & 1.8 & 2.1 & 3.9 & 0.2 & 0.22 & 0 \\
\hline $5 \mathrm{H}-4,124-126$ & 42.84 & 7.3 & 51.6 & 41.1 & 1.3 & 3.8 & 1.5 & 5.3 & 0 & 1.0 & 0.9 & 1.9 & 0.1 & 0.23 & 0 \\
\hline $5 \mathrm{H}-5,26-28$ & 43.36 & 9.4 & 54.6 & 36.1 & 1.5 & 1.8 & 2.7 & 4.5 & 0 & 2.7 & 1.9 & 4.6 & 0.3 & 0.19 & 0 \\
\hline $5 \mathrm{H}-5,98-100$ & 44.08 & 13.3 & 50.5 & 34.2 & 1.5 & 0.7 & 6.2 & 6.9 & 0 & 4.9 & 1.2 & 6.1 & 0.3 & 0.16 & 0 \\
\hline
\end{tabular}

${ }^{\mathrm{a}}$ Including volcanic ash component. 
APPENDIX B

Hole 701C Data

\begin{tabular}{|c|c|c|c|c|c|c|c|c|c|c|c|c|c|c|c|c|}
\hline \multirow[b]{2}{*}{$\begin{array}{l}\text { Core, section, } \\
\text { interval }(\mathrm{cm})\end{array}$} & \multirow[b]{2}{*}{$\begin{array}{l}\text { Depth } \\
\text { (mbsf) }\end{array}$} & \multirow[b]{2}{*}{$\begin{array}{l}\text { Sand } \\
(\%)\end{array}$} & & & & & & and fractio & compon & nents (relat & ive \%) & & & & & \\
\hline & & & $\begin{array}{l}\text { Silt } \\
(\%)\end{array}$ & $\begin{array}{l}\text { Clay } \\
(\%)\end{array}$ & $\begin{array}{l}\text { Silt/ } \\
\text { clay }\end{array}$ & $\begin{array}{l}\text { Dia- } \\
\text { toms }\end{array}$ & $\begin{array}{l}\text { Radio- } \\
\text { larians }\end{array}$ & $\begin{array}{l}\text { Total } \\
\text { bio- } \\
\text { siliceous }\end{array}$ & $\begin{array}{l}\text { Total } \\
\text { car- } \\
\text { bonate }\end{array}$ & Detrital & $\begin{array}{l}\text { Volcanic } \\
\text { ash }\end{array}$ & $\begin{array}{c}\text { Total } \\
\text { non- } \\
\text { biogenic }\end{array}$ & $\begin{array}{c}\text { Authigenic } \\
\text { particles } \\
(\%)\end{array}$ & $\begin{array}{c}\text { Organic } \\
\text { carbon } \\
(\%)\end{array}$ & $\begin{array}{c}\text { Car- } \\
\text { bonate } \\
(\%)\end{array}$ & $\begin{array}{c}\mathrm{H}_{2} \mathrm{O} \\
(\%)\end{array}$ \\
\hline $114-701 C$ - & & & & & & & & & & & & & & & & \\
\hline $1 \mathrm{H}-1,2-4$ & 0.02 & 6.9 & 51.7 & 41.4 & 1.3 & 0.3 & 4.3 & 4.6 & 0 & 0.3 & 1.9 & 2.2 & 0.1 & 0.35 & 0.25 & 58.6 \\
\hline $1 \mathrm{H}-1,15-17$ & 0.15 & 20.7 & 51.9 & 27.4 & 1.9 & 1.5 & 8.6 & 10.1 & 0 & 0.1 & 10.8 & 10.9 & 0.1 & 0.27 & 0.25 & 68.2 \\
\hline IH-1, 30-32 & 0.30 & & & & & & & & & & & & & 1.21 & 0.25 & 64.3 \\
\hline $1 \mathrm{H}-1,45-47$ & 0.45 & 3.7 & 48.0 & 48.3 & 1.0 & 0.1 & 1.4 & 1.5 & 0 & 0.1 & 2.4 & 2.5 & 0 & 0.64 & 0.1 & 62.97 \\
\hline $1 \mathrm{H}-1,60-62$ & 0.60 & 5.8 & 47.5 & 46.8 & 1.0 & 0.1 & 1.0 & 1.1 & 0 & 0.1 & 4.8 & 4.9 & 0 & 0.54 & 0.25 & 66.0 \\
\hline $1 \mathrm{H}-1,75-77$ & 0.75 & 9.1 & 53.3 & 37.6 & 1.4 & 0.9 & 2.6 & 3.5 & 0 & 0.2 & 5.3 & 5.5 & 0.1 & 0.56 & 0.25 & 66.5 \\
\hline $1 \mathrm{H}-1,90-92$ & 0.90 & 13.1 & 53.2 & 33.7 & 1.6 & 6.1 & 2.1 & 8.2 & 0 & 0.1 & 4.6 & 4.7 & 0.1 & 0.51 & 0.50 & 61.4 \\
\hline $1 \mathrm{H}-1,105-107$ & 1.05 & 8.7 & 53.8 & 37.5 & 1.4 & 7.2 & 0.5 & 7.7 & 0 & 0 & 1.3 & 1.3 & 0 & 0.47 & 0.25 & 65.8 \\
\hline $1 \mathrm{H}-1,120-122$ & 1.20 & 13.4 & 49.9 & 36.7 & 1.4 & 7.2 & 1.8 & 9.0 & 0 & 0.2 & 3.6 & 3.8 & 0.2 & 0.49 & 0.25 & 65.7 \\
\hline IH-1, 135-137 & 1.35 & 10.2 & 51.9 & 39.0 & 1.3 & 5.3 & 1.6 & 6.9 & 0 & 0.1 & 2.9 & 3.0 & 0.1 & 0.53 & 0.25 & 62.3 \\
\hline 1H-2, 2-4 & 1.52 & 12.1 & 49.1 & 38.8 & 1.3 & 0.8 & 2.6 & 3.4 & 0 & 0.2 & 8.3 & 8.5 & 0.1 & 0.54 & 0.17 & 64.0 \\
\hline $1 \mathrm{H}-2,15-17$ & 1.65 & 9.8 & 42.6 & 47.6 & 0.9 & 0.2 & 3.4 & 3.6 & 0 & 0.2 & 6.1 & 6.3 & 0.1 & 0.50 & 0.17 & 64.1 \\
\hline $1 \mathrm{H}-2,30-32$ & 1.80 & 14.1 & 52.4 & 33.5 & 1.6 & 4.5 & 2.5 & 7.0 & 0 & 0.1 & 6.9 & 7.0 & 0 & 0.45 & 0.17 & 64.9 \\
\hline $1 \mathrm{H}-2,45-47$ & 1.95 & 10.9 & 55.7 & 33.4 & 1.7 & 5.7 & 2.3 & 8.0 & 0 & 0.5 & 3.4 & 4.0 & 0 & 0.44 & 0.42 & 64.2 \\
\hline $1 \mathrm{H}-2,60-62$ & 2.10 & 15.5 & 49.2 & 35.3 & 1.4 & 7.0 & 2.7 & 9.7 & 0 & 2.1 & 4.0 & 6.1 & 0 & 0.39 & 0.33 & 58.8 \\
\hline $1 \mathrm{H}-2,75-77$ & 2.25 & 10.9 & 55.7 & 32.4 & 1.7 & 5.8 & 2.8 & 8.6 & 0 & 0.2 & 2.2 & 2.4 & 0 & 0.48 & 0.17 & 65.5 \\
\hline $1 \mathrm{H}-2,90-92$ & 2.40 & 9.1 & 57.6 & 33.3 & 1.7 & 4.7 & 2.2 & 6.9 & 0 & 0.7 & 1.4 & 2.1 & 0 & 0.44 & 0.25 & 66.8 \\
\hline $1 \mathrm{H}-2,105-107$ & 2.55 & 3.5 & 55.5 & 41.0 & 1.4 & 1.1 & 1.5 & 2.6 & 0 & 0.6 & 0.8 & 1.4 & 0 & 0.40 & 0.25 & 67.2 \\
\hline $1 \mathrm{H}-2,120-122$ & 2.70 & 3.0 & 62.9 & 34.1 & 1.8 & 0.9 & 1.5 & 2.4 & 0 & 0.1 & 0.5 & 0.6 & 0 & 0.35 & 0.25 & 68.1 \\
\hline $1 \mathrm{H}-2,135-137$ & 2.85 & 4.3 & 57.3 & 38.4 & 1.5 & 3.6 & 0.3 & 3.9 & 0 & 0 & 0.1 & 0.1 & 0 & 0.42 & 0.17 & 66.0 \\
\hline $1 \mathrm{H}-3,2-4$ & 3.02 & 9.0 & 45.4 & 45.6 & 1.0 & 4.5 & 2.0 & 6.5 & 0 & 0.8 & 1.7 & 2.5 & 0.3 & 0.37 & 0.42 & 65.5 \\
\hline $1 \mathrm{H}-3,15-17$ & 3.15 & 4.9 & 58.6 & 36.5 & 1.6 & 3.7 & 0.5 & 4.2 & 0 & 0.3 & 0.5 & 0.8 & 0.1 & 0.39 & 0.33 & 66.1 \\
\hline $1 \mathrm{H}-3,30-32$ & 3.30 & 11.3 & 54.6 & 34.1 & 1.6 & 4.4 & 1.9 & 6.3 & 0 & 0.3 & 1.1 & 1.4 & 0 & 0.40 & 0.25 & 64.6 \\
\hline IH- $3,45-47$ & 3.45 & 16.2 & 38.2 & 45.6 & 0.8 & 2.8 & 3.0 & 5.8 & 0 & 5.1 & 5.1 & 10.2 & 0.1 & 0.39 & 0.25 & 53.4 \\
\hline $1 \mathrm{H}-3,60-62$ & 3.60 & 11.4 & 45.9 & 42.7 & 1.0 & 10.2 & 0.1 & 10.3 & 0 & 0.3 & 0.4 & 0.7 & 0 & 0.45 & 0.17 & 63.2 \\
\hline $1 \mathrm{H}-3,75-77$ & 3.75 & 8.6 & 49.1 & 42.3 & 1.2 & 1.7 & 1.9 & 3.6 & 0 & 0.7 & 3.5 & 4.2 & 0.2 & 0.42 & 0.25 & 62.4 \\
\hline $1 \mathrm{H}-3,90-92$ & 3.90 & 3.7 & 46.7 & 49.7 & 0.9 & 0.1 & 1.6 & 1.7 & 0 & 0.2 & 2.1 & 2.3 & 0 & 0.39 & 0.25 & 63.2 \\
\hline $1 \mathrm{H}-3,105-107$ & 4.05 & 14.3 & 54.4 & 31.3 & 1.7 & 0.4 & 3.2 & 3.6 & 0 & 1.6 & 8.5 & 10.1 & 0.2 & 0.33 & 0.33 & 61.0 \\
\hline $1 \mathrm{H}-3,120-122$ & 4.20 & 9.4 & 53.9 & 36.7 & 1.5 & 3.8 & 3.6 & 7.4 & 0 & 0.5 & 1.1 & 1.6 & 0 & 0.35 & 0.17 & 61.0 \\
\hline $1 \mathrm{H}-3,135-137$ & 4.35 & 7.5 & 41.7 & 50.8 & 0.8 & 4.6 & 2.6 & 7.2 & 0 & 0.2 & 0.6 & 0.8 & 0.1 & 0.39 & 0.25 & 67.3 \\
\hline $1 \mathrm{H}-4,2-4$ & 4.52 & 9.1 & 53.4 & 37.5 & 1.4 & 1.1 & 4.8 & 5.9 & 0 & 0.8 & 2.3 & 3.1 & 0.2 & 0.29 & 0.33 & 68.9 \\
\hline $1 \mathrm{H}-4,15-17$ & 4.65 & 3.2 & 60.8 & 36.0 & 1.7 & 0.4 & 1.9 & 2.3 & 0 & 0.2 & 0.5 & 0.7 & 0 & & & \\
\hline $1 \mathrm{H}-4,30-32$ & 4.80 & 9.8 & 54.0 & 36.2 & 1.5 & 0.5 & 5.4 & 5.9 & 0 & 2.0 & 2.1 & 4.1 & 0.1 & 0.22 & 0.42 & 67.9 \\
\hline $1 \mathrm{H}-4,45-47$ & 4.95 & 9.4 & 50.8 & 39.8 & 1.3 & 2.1 & 4.0 & 6.1 & 0 & 1.2 & 1.7 & 2.9 & 0.1 & 0.07 & 0.16 & 69.3 \\
\hline $1 \mathrm{H}-4,60-62$ & 5.10 & 16.2 & 54.2 & 29.6 & 1.8 & 10.1 & 4.0 & 14.1 & 0 & 0 & 1.9 & 1.9 & 0.1 & 0.29 & 0.24 & 68.5 \\
\hline $1 \mathrm{H}-4,75-77$ & 5.25 & 7.4 & 58.6 & 34.0 & 1.7 & 3.0 & 3.6 & 6.6 & 0 & 0 & 0.4 & 0.4 & 0.1 & 0.34 & 0.24 & 67.3 \\
\hline $1 \mathrm{H}-4,90-92$ & 5.40 & 9.1 & 61.9 & 29.0 & 2.1 & 2.1 & 4.1 & 6.2 & 0 & 2.0 & 1.8 & 2.8 & 0.1 & 0.32 & 0.31 & 69.3 \\
\hline $1 \mathrm{H}-4,105-107$ & 5.55 & 7.4 & 61.7 & 30.9 & 2.0 & 1.3 & 5.0 & 6.3 & 0 & 0 & 0.7 & 0.7 & 0.9 & 0.28 & 0.40 & 66.7 \\
\hline $1 \mathrm{H}-4,120-122$ & 5.70 & 7.8 & 59.4 & 32.8 & 1.8 & 2.6 & 4.3 & 6.9 & 0 & 0.1 & 1.0 & 1.1 & 0.1 & 0.32 & 0.19 & 68.1 \\
\hline $1 \mathrm{H}-4,135-137$ & 5.85 & 6.3 & 59.6 & 34.1 & 1.7 & 1.1 & 2.8 & 3.9 & 0 & 0.4 & 1.7 & 2.1 & 0 & 0.30 & 0.19 & 67.6 \\
\hline $1 \mathrm{H}-5,2-4$ & 6.02 & & & & & & & & & & & & & 0.35 & 0.20 & 67.5 \\
\hline $1 \mathrm{H}-5,15-17$ & 6.15 & 9.1 & 56.3 & 34.6 & 1.6 & 1.1 & 3.9 & 5.0 & 0 & 0.9 & 2.9 & 3.8 & 0.2 & 0.34 & 0.15 & 68.2 \\
\hline $1 \mathrm{H}-5,30-32$ & 6.30 & 6.4 & 57.5 & 36.1 & 1.6 & 0.4 & 4.6 & 5.0 & 0 & 0.3 & 0.7 & 1.0 & 0.1 & 0.31 & 0.24 & 66.6 \\
\hline $1 \mathrm{H}-5,45-47$ & 6.45 & 8.3 & 48.4 & 43.3 & 1.1 & 0.5 & 6.1 & 6.6 & 0 & 0.7 & 0.7 & 1.4 & 0.1 & 0.19 & 0.22 & 65.5 \\
\hline $1 \mathrm{H}-5,60-62$ & 6.60 & 4.1 & 45.8 & 50.1 & 0.9 & 3.5 & 0.5 & 4.0 & 0 & 0 & 0 & 0 & 0 & 0.22 & 0.20 & 67.1 \\
\hline $1 \mathrm{H}-5,75-77$ & 6.75 & 10.1 & 43.9 & 46.0 & 1.0 & 0.8 & 3.8 & 4.6 & 0 & 0.5 & 0.9 & 1.4 & 0.1 & 0.26 & 0.19 & 61.3 \\
\hline $1 \mathrm{H}-5,90-92$ & 6.90 & & & & & & & & & & & & & 0.22 & 0.24 & 64.2 \\
\hline $1 \mathrm{H}-5,105-107$ & 7.05 & 10.6 & 50.2 & 39.2 & 1.3 & 1.9 & 6.3 & 8.2 & 0 & 1.4 & 1.4 & 2.8 & 0.1 & 0.44 & 0.17 & 64.5 \\
\hline $1 \mathrm{H}-5,120-122$ & 7.20 & 10.8 & 49.9 & 39.3 & 1.3 & 0.2 & 3.9 & 4.1 & 0 & 3.8 & 3.1 & 6.9 & 0.2 & 0.40 & 0.18 & 61.6 \\
\hline $1 \mathrm{H}-5,135-137$ & 7.35 & 15.2 & 52.4 & 32.4 & 1.6 & 9.0 & 3.1 & 12.1 & 0 & 1.4 & 1.5 & 2.9 & 0.2 & 0.42 & 0.19 & 61.6 \\
\hline $1 \mathrm{H}-6,2-4$ & 7.52 & 14.3 & 55.3 & 30.4 & 1.5 & 0.6 & 4.0 & 4.6 & 0 & 3.4 & 6.0 & 9.4 & 0.2 & 0.50 & 0.18 & 62.0 \\
\hline $1 \mathrm{H}-6,15-17$ & 7.65 & 9.8 & 54.3 & 35.8 & 1.5 & 0.6 & 6.1 & 6.7 & 0 & 1.5 & 1.7 & 3.2 & 0.6 & 0.42 & 0.28 & 63.3 \\
\hline $1 \mathrm{H}-6,30-32$ & 7.80 & 13.5 & 51.4 & 35.1 & 1.5 & 0.1 & 3.7 & 3.8 & 0 & 3.3 & 5.9 & 9.2 & 0 & 0.45 & 0.18 & 63.1 \\
\hline $1 \mathrm{H}-6,45-47$ & 7.95 & 11.2 & 48.9 & 39.9 & 1.2 & 1.2 & 4.3 & 5.5 & 0 & 2.2 & 3.7 & 5.5 & 0.3 & 0.39 & 0.18 & 61.0 \\
\hline $1 \mathrm{H}-6,60-62$ & 8.10 & 21.8 & 47.1 & 31.1 & 1.5 & 0.4 & 4.0 & 4.4 & 0 & 5.7 & 11.9 & 17.6 & 0.3 & 0.25 & 0.20 & 59.6 \\
\hline $1 \mathrm{H}-6,75-77$ & 8.25 & 17.7 & 38.7 & 43.1 & 0.8 & & & & & & & & & 0.35 & 0.17 & 52.6 \\
\hline $1 \mathrm{H}-6,90-92$ & 8.40 & 28.0 & 44.0 & 28.0 & 1.6 & 2.8 & 3.4 & 6.2 & 0 & 9.4 & 7.4 & 16.8 & 0.4 & 0.19 & 0.65 & 51.1 \\
\hline $1 \mathrm{H}-6,105-107$ & 8.55 & & & & & & & & & & & & & 0.32 & 0.76 & 59.2 \\
\hline $1 \mathrm{H}-6,120-122$ & 8.70 & 15.2 & 57.9 & 26.9 & 2.2 & & & & & & & & & 0.30 & 0.23 & 60.0 \\
\hline $1 \mathrm{H}-6,135-137$ & 8.85 & 16.5 & 54.1 & 29.4 & 1.8 & 2.2 & 8.3 & 10.5 & 0 & 2.2 & 4.3 & 6.5 & 0.1 & 0.26 & 0.21 & 0.64 \\
\hline $1 \mathrm{H}-7,2-4$ & 9.02 & 11.3 & 57.4 & 31.3 & 1.8 & 9.7 & 1.1 & 10.6 & 0 & 0.2 & 0.2 & 0.4 & 0 & 0.35 & 0.08 & 64.4 \\
\hline $1 \mathrm{H}-7,15-17$ & 9.15 & 21.9 & 44.6 & 33.5 & 1.4 & 5.1 & 5.7 & 10.8 & 0 & 7.2 & 4.0 & 11.2 & 0.2 & 0.35 & 0.08 & 60.4 \\
\hline $1 \mathrm{H}-7,30-32$ & 9.30 & 9.8 & 59.0 & 31.2 & 1.9 & 1.1 & 5.1 & 6.2 & 0 & 1.4 & 2.4 & 3.8 & 0 & 0.31 & 0.08 & 63.8 \\
\hline $1 \mathrm{H}-7,45-47$ & 9.45 & & & & & & & & & & & & & 0.32 & 0.08 & 57.1 \\
\hline $2 \mathrm{H}-3,110-112$ & 10.40 & 29.7 & 43.3 & 27.0 & 1.6 & 5.1 & 9.6 & 14.7 & 0 & 6.0 & 8.7 & 14.7 & 0.7 & 0.40 & 0.80 & 62.9 \\
\hline $2 \mathrm{H}-3,135-137$ & 10.65 & 16.0 & 43.4 & 40.6 & 1.1 & 8.5 & 4.1 & 12.6 & 0 & 1.3 & 2.1 & 3.4 & 0.1 & 0.30 & 0.24 & 64.2 \\
\hline $2 \mathrm{H}-4,10-12$ & 10.90 & 3.5 & 49.6 & 36.9 & 1.4 & 1.8 & 8.8 & 10.6 & 0 & 0.7 & 2.7 & 3.4 & 0.1 & 0.26 & 0.22 & 66.3 \\
\hline $2 \mathrm{H}-4,35-37$ & 11.15 & 15.6 & 50.1 & 34.3 & 1.5 & 0.3 & 9.3 & 9.6 & 0 & 0.4 & 5.0 & 5.4 & 0.2 & 0.28 & 0.27 & 64.1 \\
\hline $2 \mathrm{H}-5,15-17$ & 12.45 & 7.1 & 59.3 & 33.6 & 1.7 & 0 & 5.4 & 5.4 & 0 & 1.0 & 0.6 & 1.6 & 0 & 0.25 & 0.27 & 68.5 \\
\hline $2 \mathrm{H}-5,40-42$ & 12.70 & 15.2 & 43.7 & 41.1 & 1.1 & 0.6 & 2.8 & 3.4 & 0 & 8.0 & 3.6 & 11.6 & 0.2 & 0.45 & 0.27 & 49.6 \\
\hline $2 \mathrm{H}-5,65-67$ & 12.95 & 15.8 & 35.3 & 38.9 & 0.9 & 0.3 & 4.6 & 4.9 & 0 & 13.3 & 7.8 & 21.1 & 0.4 & 0.47 & 0.27 & 49.6 \\
\hline $2 \mathrm{H}-5,89-91$ & 13.19 & 11.5 & 58.2 & 30.3 & 1.9 & 0.5 & 6.9 & 7.4 & 0 & 2.9 & 1.7 & 4.6 & 0.2 & 0.23 & 0.27 & 61.5 \\
\hline $2 \mathrm{H}-5,114-116$ & 13.44 & 11.3 & 57.7 & 31.0 & 1.9 & 0.8 & 6.5 & 7.3 & 0 & 2.4 & 1.3 & 3.7 & 0.1 & 0.38 & 0.26 & 63.4 \\
\hline
\end{tabular}


APPENDIX B

Hole 701C Data

Sand fraction components (relative \%)

\begin{tabular}{|c|c|c|c|c|c|c|c|c|c|c|c|c|c|c|c|c|}
\hline $\begin{array}{l}\text { Core, section, } \\
\text { interval }(\mathrm{cm})\end{array}$ & $\begin{array}{l}\text { Depth } \\
\text { (mbsf) }\end{array}$ & $\begin{array}{l}\text { Sand } \\
(\%)\end{array}$ & $\begin{array}{l}\text { Silt } \\
(\%)\end{array}$ & $\begin{array}{l}\text { Clay } \\
(\%)\end{array}$ & $\begin{array}{l}\text { Silt/ } \\
\text { clay }\end{array}$ & $\begin{array}{l}\text { Dia- } \\
\text { toms }\end{array}$ & $\begin{array}{l}\text { Radio- } \\
\text { larians }\end{array}$ & $\begin{array}{c}\text { Total } \\
\text { bio- } \\
\text { siliceous }\end{array}$ & $\begin{array}{c}\text { Total } \\
\text { car- } \\
\text { bonate }\end{array}$ & Detrital & $\begin{array}{l}\text { Volcanic } \\
\text { ash }\end{array}$ & $\begin{array}{c}\text { Total } \\
\text { non- } \\
\text { biogenic }\end{array}$ & $\begin{array}{c}\text { Authigenic } \\
\text { particles } \\
(\%)\end{array}$ & $\begin{array}{c}\text { Organic } \\
\text { carbon } \\
(\%)\end{array}$ & $\begin{array}{c}\text { Car- } \\
\text { bonate } \\
(\%)\end{array}$ & $\begin{array}{l}\mathrm{H}_{2} \mathrm{O} \\
(\%)\end{array}$ \\
\hline $2 \mathrm{H}-5,140-142$ & 13.70 & 25.4 & 48.3 & 26.3 & 1.8 & 3.0 & 14.5 & 17.5 & 0 & 4.2 & 3.3 & 7.5 & 0.2 & 0.40 & 0.30 & 58.1 \\
\hline $2 \mathrm{H}-6,15-17$ & 13.95 & 16.6 & 57.7 & 25.7 & 2.3 & 1.2 & 9.7 & 10.9 & 0 & 3.4 & 2.7 & 6.1 & 0.1 & 0.39 & 0.27 & 66.4 \\
\hline $2 \mathrm{H}-6,40-42$ & 14.20 & 19.4 & 53.6 & 27.0 & 2.0 & 1.9 & 11.2 & 13.1 & 0 & 1.5 & 4.4 & 5.9 & 0.3 & 0.34 & 0.26 & 56.1 \\
\hline $2 \mathrm{H}-6,69-71$ & 14.49 & 26.8 & 38.7 & 34.5 & 1.1 & 1.4 & 6.4 & 7.8 & 0 & 5.7 & 13.5 & 19.2 & 0.2 & 0.51 & 0.25 & 57.8 \\
\hline $2 \mathrm{H}-6,95-97$ & 14.75 & 21.0 & 50.3 & 28.7 & 1.7 & & & & & & & & 0.2 & 0.45 & 0.23 & 54.5 \\
\hline $3 \mathrm{H}-1,0-2$ & 15.80 & 18.6 & 62.5 & 18.9 & 3.3 & 0.2 & 2.4 & 2.6 & 0 & 0.2 & 0.2 & 0.4 & 0 & 0.30 & 0.53 & 71.5 \\
\hline $3 \mathrm{H}-1,25-27$ & 16.05 & 43.6 & 60.3 & 36.1 & 1.7 & 1.4 & 1.8 & 3.2 & 0 & 0.4 & 0.4 & 0.8 & 0 & 0.42 & 7.10 & 69.3 \\
\hline $3 \mathrm{H}-1,50-52$ & 16.30 & 43.6 & 50.9 & 45.5 & 1.1 & 0.4 & 2.8 & 3.2 & 0 & 0.2 & 0.6 & 0.8 & 0 & 0.57 & 2.41 & 66.1 \\
\hline $3 \mathrm{H}-1,75-77$ & 16.55 & 14.2 & 41.3 & 44.5 & 0.9 & 3.6 & 8.4 & 12.0 & 0 & 0.7 & 1.3 & 2.0 & 0 & 0.76 & 0.23 & 46.8 \\
\hline $3 \mathrm{H}-1,100-102$ & 16.80 & 18.7 & 35.9 & 45.6 & 0.8 & 1.9 & 5.1 & 7.0 & 0 & 2.7 & 9.3 & 12.0 & 0.4 & 0.76 & 0.23 & 46.8 \\
\hline $3 \mathrm{H}-1,125-127$ & 17.05 & 18.8 & 33.1 & 48.1 & 0.7 & 1.0 & 5.8 & 6.8 & 0 & 5.5 & 6.7 & 12.2 & 0.3 & 0.54 & 0.61 & 47.7 \\
\hline $3 \mathrm{H}-1,147-149$ & 17.27 & 29.4 & 38.4 & 32.2 & 1.1 & 6.1 & 9.0 & 15.1 & 0 & 5.2 & 8.1 & 13.3 & 0.6 & 0.42 & 0.65 & 51.3 \\
\hline $3 \mathrm{H}-2,0-2$ & 17.30 & 18.5 & 47.0 & 34.5 & 1.4 & 1.0 & 4.9 & 5.9 & 0 & 7.8 & 4.9 & 12.7 & 0.4 & 0.48 & 0.40 & 54.4 \\
\hline $3 \mathrm{H}-2,25-27$ & 17.55 & 22.7 & 44.0 & 33.3 & 1.3 & 1.1 & 6.0 & 7.1 & 0 & 4.8 & 10.8 & 15.6 & 0.2 & 0.39 & 0.49 & 47.1 \\
\hline $3 \mathrm{H}-2,50-52$ & 17.80 & 4.2 & 64.5 & 31.3 & 2.1 & 0 & 1.9 & 1.9 & 0 & 0.8 & 1.2 & 2.0 & 0 & 0.35 & 0.50 & 68.5 \\
\hline $3 \mathrm{H}-2,75-77$ & 18.05 & & & & & & & & & & & & & 0.32 & 0.48 & 60.9 \\
\hline $3 \mathrm{H}-2,98-100$ & 18.25 & 5.0 & 58.2 & 36.8 & 1.6 & 2.0 & 2.0 & 4.0 & 0 & 0.1 & 0.9 & 1.0 & 0 & 0.37 & 0.44 & 61.7 \\
\hline $3 \mathrm{H}-2,125-127$ & 18.55 & 8.4 & 57.6 & 34.0 & 1.7 & 0.2 & 5.8 & 6.0 & 0 & 0.4 & 1.1 & 1.5 & 0 & 0.32 & 0.57 & 67.4 \\
\hline $3 \mathrm{H}-2,147-149$ & 18.77 & 1.7 & 62.9 & 35.3 & 1.8 & 0.5 & 1.5 & 2.0 & 0 & 0 & 0 & 0 & 0 & 0.46 & 0.49 & 69.1 \\
\hline $3 \mathrm{H}-3,0-2$ & 18.80 & 2.2 & 61.7 & 36.1 & 1.8 & 1.4 & 0.6 & 2.0 & 0 & 0 & 0 & 0 & 0 & 0.49 & 0.43 & 71.3 \\
\hline $3 \mathrm{H}-3,25-27$ & 19.05 & 1.4 & 58.4 & 40.2 & 1.5 & 0.4 & 0.5 & 0.9 & 0 & 0 & 0.1 & 0.1 & 0 & 0.45 & 0.42 & 53.4 \\
\hline $3 \mathrm{H}-3,50-52$ & 19.30 & 2.4 & 61.5 & 36.1 & 1.7 & 1.8 & 0.2 & 2.0 & 0 & 0 & 0 & 0 & 0 & 0.42 & 0.30 & 70.6 \\
\hline $3 \mathrm{H}-3,75-77$ & 19.55 & 2.0 & 44.7 & 53.3 & 0.8 & & & & & & & & & 0.41 & 0.45 & 69.0 \\
\hline $3 \mathrm{H}-3,100-102$ & 19.80 & 11.7 & 52.6 & 35.7 & 1.5 & 3.0 & 5.4 & 8.4 & 0 & 1.2 & 2.2 & 3.5 & 0.1 & 0.41 & 0.48 & 61.4 \\
\hline $3 \mathrm{H}-3,125-127$ & 20.05 & 22.4 & 38.2 & 39.4 & 1.0 & 3.1 & 7.0 & 10.1 & 0 & 3.1 & 7.5 & 10.6 & 1.4 & 0.65 & 0.34 & 46.5 \\
\hline $3 \mathrm{H}-3,147-149$ & 20.27 & 7.2 & 59.2 & 33.6 & 1.8 & 7.0 & 0 & 7.0 & 0 & 0 & 0 & 0 & 0 & 0.55 & 0.41 & 73.5 \\
\hline $3 \mathrm{H}-4,0-2$ & 20.30 & 4.2 & 62.3 & 33.6 & 1.9 & 4.0 & 0 & 4.0 & 0 & 0 & 0 & 0 & 0 & 0.52 & 0.37 & 73.2 \\
\hline $3 \mathrm{H}-4,25-27$ & 20.55 & 3.8 & 60.1 & 36.1 & 1.7 & 6.3 & 1.1 & 7.4 & 0 & 0.2 & 0.4 & 0.6 & 0 & 0.45 & 0.41 & 18.5 \\
\hline $3 \mathrm{H}-4,50-52$ & 20.80 & 13.6 & 50.2 & 36.2 & 1.4 & 0.8 & 9.0 & 9.8 & 0 & 2.1 & 1.8 & 3.9 & 0.3 & 0.54 & 0.45 & 59.2 \\
\hline $3 \mathrm{H}-4,75-77$ & 21.05 & 30.9 & 36.5 & 32.6 & 1.1 & 0.6 & 6.2 & 6.8 & 0 & 1.7 & 21.4 & 23.3 & 0.9 & 0.47 & 0.30 & 43.8 \\
\hline $3 \mathrm{H}-4,100-102$ & 21.30 & 19.6 & 57.0 & 23.4 & 2.5 & 0.6 & 6.2 & 6.8 & 0 & 0.2 & 12.8 & 13.0 & 0.1 & 0.40 & 0.41 & 82.0 \\
\hline $3 \mathrm{H}-4,125-127$ & 21.55 & 7.2 & 60.5 & 32.3 & 1.9 & 1.5 & 5.1 & 6.6 & 0 & 0.1 & 0.3 & 0.4 & 0 & 0.31 & 0.51 & 61.0 \\
\hline $3 \mathrm{H}-4,147-149$ & 21.77 & 5.3 & 62.2 & 32.5 & 1.9 & 1.0 & 3.0 & 4.0 & 0 & 0.3 & 0.7 & 1.0 & 0 & 0.21 & 0.48 & 63.9 \\
\hline $3 \mathrm{H}-5,0-2$ & 21.80 & 5.3 & 62.2 & 32.5 & 1.9 & 3.7 & 1.0 & 4.7 & 0 & 0.1 & 0.2 & 0.3 & 0 & 0.22 & 0.38 & 67.0 \\
\hline $3 \mathrm{H}-5,25-27$ & 22.05 & 3.4 & 62.8 & 33.8 & 1.9 & 2.7 & 0.3 & 3.0 & 0 & 0 & 0 & 0 & 0 & 0.19 & 0.48 & 68.3 \\
\hline $3 \mathrm{H}-5,50-52$ & 22.30 & 5.9 & 63.0 & 31.1 & 2.0 & 5.5 & 0.3 & 5.8 & 0 & 0 & 0.2 & 0.2 & 0 & 0.23 & 0.72 & 65.5 \\
\hline $3 \mathrm{H}-5,75-77$ & 22.55 & 13.8 & 51.9 & 34.3 & 1.5 & 5.9 & 4.1 & 10.0 & 0 & 0.9 & 3.1 & 4.0 & 0 & 0.24 & 0.57 & 56.9 \\
\hline $3 \mathrm{H}-5,98-100$ & 22.78 & 24.4 & 36.3 & 39.3 & 0.9 & 1.7 & 7.9 & 9.6 & 0 & 3.6 & 10.8 & 14.4 & 0.3 & 0.52 & 0.39 & 52.7 \\
\hline $3 \mathrm{H}-5,125-127$ & 23.05 & 11.3 & 67.0 & 21.7 & 3.1 & 0.4 & 0.1 & 0.5 & 0 & 0 & 0.5 & 0.5 & 0 & 0.15 & 0.44 & 47.4 \\
\hline $3 \mathrm{H}-5,147-149$ & 23.27 & 9.8 & 55.3 & 34.9 & 1.6 & 3.5 & 3.8 & 7.3 & 0 & 0.7 & 2.0 & 2.7 & 0 & 0.24 & 0.37 & 59.3 \\
\hline $3 \mathrm{H}-6,0-2$ & 23.30 & 11.8 & 62.3 & 25.9 & 2.4 & 5.4 & 3.8 & 7.3 & 0 & 0.7 & 2.0 & 2.7 & 0 & 0.21 & 0.35 & 56.2 \\
\hline $3 \mathrm{H}-6,25-27$ & 23.55 & 18.5 & 57.3 & 24.4 & 2.3 & 16.0 & 1.1 & 17.1 & 0 & 0.4 & 0.5 & 0.9 & 0 & 0.25 & 0.38 & 63.0 \\
\hline $3 \mathrm{H}-6,50-52$ & 23.80 & 27.7 & 48.1 & 24.2 & 2.0 & 27.4 & 0 & 27.4 & 0 & 0.3 & 0.3 & 0.6 & 0.3 & 0.17 & 0.38 & 67.7 \\
\hline $3 \mathrm{H}-6,75-77$ & 24.55 & 18.6 & 62.5 & 18.9 & 3.3 & 16.0 & 1.1 & 17.1 & 0 & 0.9 & 1.0 & 1.9 & 0 & 0.26 & 0.35 & 61.6 \\
\hline $3 \mathrm{H}-6,100-102$ & 24.55 & 13.3 & 61.4 & 25.3 & 2.4 & 8.4 & 0.3 & 8.7 & 0 & 0.1 & 0.2 & 0.3 & 0 & 0.19 & 0.37 & 58.2 \\
\hline $3 \mathrm{H}-6,125-127$ & 24.80 & 6.0 & 69.0 & 25.0 & 2.8 & 12.0 & 0.9 & 12.9 & 0 & 0 & 0.1 & 0.1 & 0 & 0.20 & 0.34 & 61.0 \\
\hline $3 \mathrm{H}-6,147-149$ & 24.97 & & & & & 5.4 & 0.6 & 6.0 & 0 & 0 & 0 & 0 & 0 & 0.19 & 0.37 & 62.4 \\
\hline $3 \mathrm{H}-7,0-2$ & 24.80 & 3.9 & 67.3 & 28.8 & 2.3 & 3.3 & 0.7 & 4.0 & 0 & 0 & 0 & 0 & 0 & 0.16 & 0.54 & 65.7 \\
\hline $3 \mathrm{H}-7,25-27$ & 25.05 & 8.1 & 58.6 & 33.3 & 1.7 & 6.8 & 1.2 & 8.0 & 0 & 0 & 0 & 0 & 0 & 0.19 & 0.35 & 67.6 \\
\hline $4 \mathrm{H}-1,10-12$ & 25.40 & 3.7 & 55.2 & 41.1 & 1.3 & 0.5 & 2.5 & 3.0 & 0 & 0.1 & 0.9 & 1.0 & 0 & 0.35 & 3.30 & 69.0 \\
\hline $4 \mathrm{H}-1,35-37$ & 25.65 & 12.2 & 40.6 & 47.2 & 0.9 & 0.4 & 3.4 & 3.8 & 0 & 1.1 & 6.7 & 7.8 & 0.4 & 0.51 & 0.36 & 49.7 \\
\hline $4 \mathrm{H}-1,60-62$ & 25.90 & 17.2 & 47.2 & 33.7 & 1.3 & 0.2 & 5.8 & 6.0 & 0 & 1.1 & 9.4 & 10.5 & 0.5 & 0.43 & 0.47 & 57.6 \\
\hline $4 \mathrm{H}-1,85-87$ & 26.15 & 10.7 & 60.3 & 29.0 & 2.1 & 0.3 & 4.5 & 4.8 & 0 & 0.1 & 6.1 & 6.2 & 0 & 0.27 & 0.43 & 70.4 \\
\hline $4 \mathrm{H}-1,110-112$ & 26.40 & 2.2 & 63.6 & 34.2 & 1.9 & 0.5 & 1.4 & 1.9 & 0 & 0 & 0.1 & 0.1 & 0 & 0.34 & 0.33 & 73.5 \\
\hline $4 \mathrm{H}-1,135-137$ & 26.65 & 6.1 & 56.5 & 37.4 & 1.5 & 0.5 & 4.8 & 5.3 & 0 & 0.1 & 0.6 & 0.7 & 0 & 0.38 & 0.37 & 71.1 \\
\hline $4 \mathrm{H}-2,60-62$ & 27.40 & 22.4 & 34.2 & 43.4 & 0.8 & 0.2 & 7.5 & 7.7 & 0 & 1.1 & 12.1 & 13.2 & 1.0 & 0.51 & 0.41 & 53.3 \\
\hline $4 \mathrm{H}-2,85-87$ & 27.65 & 5.0 & 62.6 & 33.4 & 1.9 & 1.5 & 3.2 & 4.7 & 0 & 0 & 0.3 & 0.3 & 0 & 0.26 & 0.49 & 73.4 \\
\hline $4 \mathrm{H}-2,135-137$ & 28.15 & 18.4 & 42.3 & 39.3 & 1.0 & 1.7 & 6.7 & 8.4 & 0 & 5.4 & 26.9 & 32.3 & 1.3 & 0.34 & 0.38 & 46.3 \\
\hline $4 \mathrm{H}-3,10-12$ & 28.40 & 15.3 & 57.3 & 27.4 & 2.0 & 13.0 & 1.5 & 14.5 & 0 & 0 & 0.5 & 0.5 & 0 & 0.19 & 0.40 & 63.6 \\
\hline $4 \mathrm{H}-3,35-37$ & 28.65 & 12.7 & 56.7 & 30.6 & 1.9 & 11.8 & 0.8 & 12.6 & 0 & 0.1 & 0.3 & 0.4 & 0 & 0.51 & 0.30 & 68.1 \\
\hline $4 \mathrm{H}-3,60-62$ & 28.90 & 27.7 & 35.4 & 36.9 & 1.0 & 2.2 & 10.4 & 12.6 & 0 & 1.4 & 13.7 & 15.1 & 0.4 & 0.65 & 0.34 & 48.2 \\
\hline $4 \mathrm{H}-3,85-87$ & 29.15 & 14.4 & 41.9 & 43.7 & 1.0 & 0.6 & 4.9 & 5.5 & 0 & 0.4 & 8.0 & 8.4 & 0.2 & 0.65 & 0.34 & 49.7 \\
\hline $4 \mathrm{H}-3,110-112$ & 29.40 & 22.6 & 47.1 & 30.3 & 1.6 & 17.2 & 3.0 & 20.2 & 0 & 0.7 & 2.1 & 2.8 & 0 & 0.53 & 0.34 & 57.4 \\
\hline $4 \mathrm{H}-3,135-137$ & 29.65 & 17.8 & 42.9 & 39.3 & 1.1 & 0.5 & 2.7 & 3.2 & 0 & 1.0 & 13.0 & 14.0 & 0.8 & 0.36 & 0.36 & 44.5 \\
\hline $4 \mathrm{H}-4,10-12$ & 29.90 & 7.5 & 54.2 & 38.3 & 1.4 & 2.2 & 4.8 & 7.0 & 0 & 0.2 & 1.6 & 1.8 & 0 & 0.22 & 0.42 & 46.9 \\
\hline $4 \mathrm{H}-4,35-37$ & 30.15 & 9.1 & 56.2 & 34.7 & 1.6 & 7.6 & 1.4 & 9.0 & 0 & 0 & 0 & 0 & 0 & 0.25 & 0.33 & 62.0 \\
\hline $4 \mathrm{H}-4,60-62$ & 30.40 & 14.7 & 42.8 & 42.5 & 1.0 & 0.8 & 6.0 & 6.8 & 0 & 0.3 & 7.8 & 8.1 & 0.2 & 0.67 & 0.67 & 54.4 \\
\hline $4 \mathrm{H}-5,10-12$ & 31.40 & 18.0 & 53.6 & 28.4 & 1.9 & 3.6 & 8.8 & 12.4 & 0 & 0.2 & 5.2 & 5.4 & 0.1 & 0.48 & 0.30 & 60.4 \\
\hline $4 \mathrm{H}-5,35-37$ & 31.65 & & & & & & & & & & & & & 0.39 & 0.34 & 54.6 \\
\hline $4 \mathrm{H}-5,60-62$ & 31.90 & 10.9 & 63.6 & 25.5 & 2.5 & 10.4 & 0.4 & 10.8 & 0 & 0.1 & 0.1 & 0.2 & 0 & 0.40 & 0.35 & 67.1 \\
\hline $4 \mathrm{H}-5,85-87$ & 32.15 & 17.7 & 55.4 & 26.9 & 2.1 & 16.4 & 1.6 & 18.0 & 0 & 0 & 0 & 0 & 0 & 0.52 & 0.33 & 66.4 \\
\hline $4 \mathrm{H}-6,10-12$ & 32.90 & 3.5 & 63.3 & 33.2 & 1.9 & 3.6 & 0.3 & 3.9 & 0 & 0 & 0.1 & 0.1 & 0 & 0.47 & 1.15 & 62.5 \\
\hline $4 \mathrm{H}-6,35-37$ & 33.15 & 4.8 & 65.1 & 30.1 & 2.2 & 2.5 & 2.2 & 4.7 & 0 & 0 & 0.3 & 0.3 & 0 & 0.26 & 0.48 & 64.0 \\
\hline $5 \mathrm{H}-4,60-62$ & 39.90 & 14.1 & 55.3 & 30.6 & 1.8 & 0.8 & 6.7 & 8.5 & 0 & 0.1 & 4.9 & 4.9 & 0.6 & 0.13 & 0.32 & 52.7 \\
\hline
\end{tabular}


APPENDIX B

Hole 701C Data

\begin{tabular}{|c|c|c|c|c|c|c|c|c|c|c|c|c|c|c|c|c|}
\hline \multirow[b]{2}{*}{$\begin{array}{l}\text { Core, section, } \\
\text { interval }(\mathrm{cm})\end{array}$} & \multirow[b]{2}{*}{$\begin{array}{l}\text { Depth } \\
\text { (mbsf) }\end{array}$} & \multirow[b]{2}{*}{$\begin{array}{l}\text { Sand } \\
(\%)\end{array}$} & \multirow[b]{2}{*}{$\begin{array}{l}\text { Silt } \\
(\%)\end{array}$} & \multirow[b]{2}{*}{$\begin{array}{l}\text { Clay } \\
(\%)\end{array}$} & \multirow[b]{2}{*}{$\begin{array}{l}\text { Silt/ } \\
\text { clay }\end{array}$} & \multicolumn{7}{|c|}{ Sand fraction components (relative \%) } & \multirow[b]{2}{*}{$\begin{array}{l}\text { Authigenic } \\
\text { particles } \\
(\%)\end{array}$} & \multirow[b]{2}{*}{$\begin{array}{c}\text { Organic } \\
\text { carbon } \\
(\%)\end{array}$} & \multirow[b]{2}{*}{$\begin{array}{l}\text { Car- } \\
\text { bonate } \\
(\%)\end{array}$} & \multirow[b]{2}{*}{$\begin{array}{r}\mathrm{H}_{2} \mathrm{O} \\
(\%)\end{array}$} \\
\hline & & & & & & $\begin{array}{l}\text { Dia- } \\
\text { toms }\end{array}$ & $\begin{array}{l}\text { Radio- } \\
\text { larians }\end{array}$ & $\begin{array}{l}\text { Total } \\
\text { bio- } \\
\text { siliceous }\end{array}$ & $\begin{array}{c}\text { Total } \\
\text { car- } \\
\text { bonate }\end{array}$ & Detrital & $\begin{array}{l}\text { Volcanic } \\
\text { ash }\end{array}$ & $\begin{array}{c}\text { Total } \\
\text { non- } \\
\text { biogenic }\end{array}$ & & & & \\
\hline $5 \mathrm{H}-4,85-87$ & 40.15 & 9.2 & 57.8 & 33.0 & 1.7 & 0.9 & 4.1 & 5.0 & 0 & 0.2 & 3.8 & 4.0 & 0.1 & 0.16 & 0.30 & 56.0 \\
\hline $5 \mathrm{H}-4,110-112$ & 40.40 & 9.7 & 43.2 & 47.1 & 0.9 & 0 & 3.0 & 30. & 0 & 0.3 & 6.5 & 6.8 & 0.2 & 0.37 & 0.35 & 47.9 \\
\hline $5 \mathrm{H}-4,139-141$ & 40.69 & 18.1 & 43.9 & 38.0 & 1.2 & 0.3 & 3.7 & 4.0 & 0 & 0.5 & 13.0 & 13.5 & 0.5 & 0.23 & 0.25 & 57.6 \\
\hline $5 \mathrm{H}-5,9-11$ & 40.89 & 8.0 & 56.2 & 35.8 & 1.6 & 0.1 & 5.4 & 5.5 & 0 & 0.2 & 2.3 & 2.5 & 0.1 & 0.29 & 0.24 & 54.0 \\
\hline $5 \mathrm{H}-5,35-37$ & 41.15 & 7.3 & 53.2 & 39.5 & 1.3 & 0.1 & 5.9 & 6.0 & 0 & 0.1 & 0.9 & 1.0 & 0 & 0.23 & 0.27 & 54.6 \\
\hline $5 \mathrm{H}-5,60-62$ & 41.40 & 6.9 & 52.0 & 41.1 & 1.3 & 0.1 & 5.2 & 5.3 & 0 & 0 & 1.7 & 1.7 & 0.1 & 0.26 & 0.33 & 55.5 \\
\hline $5 \mathrm{H}-5,85-87$ & 41.65 & 10.3 & 57.2 & 32.5 & 1.5 & 0 & 5.1 & 5.1 & 0 & 0.7 & 9.1 & 9.8 & 0.2 & 0.21 & 0.28 & 44.3 \\
\hline $5 \mathrm{H}-5,110-112$ & 41.90 & 10.8 & 51.6 & 37.6 & 1.4 & 0.4 & 8.9 & 9.3 & 0 & 0.2 & 1.5 & 1.7 & 0 & 0.25 & 0.35 & 48.5 \\
\hline $5 \mathrm{H}-5,135-137$ & 42.15 & 6.4 & 59.1 & 34.5 & 1.7 & 3.1 & 2.4 & 5.5 & 0 & 0 & 0.5 & 0.5 & 0 & 0.23 & 0.31 & 58.7 \\
\hline $5 H-6,9-11$ & 42.39 & 5.3 & 56.7 & 38.0 & 1.5 & 1.3 & 2.7 & 4.0 & 0 & 0.2 & 0.8 & 1.0 & 0.1 & 0.22 & 0.23 & 61.3 \\
\hline $5 \mathrm{H}-6,35-37$ & 42.65 & 12.8 & 52.6 & 34.6 & 1.5 & 0.5 & 6.9 & 7.4 & 0 & 0.3 & 5.2 & 5.5 & 0.1 & 0.25 & 0.25 & 55.0 \\
\hline $5 \mathrm{H}-6,60-62$ & 42.90 & 15.4 & 47.8 & 36.6 & 1.3 & 0.5 & 5.8 & 6.3 & 0 & 0.6 & 8.0 & 8.6 & 0.2 & 0.25 & 0.34 & 55.2 \\
\hline $5 \mathrm{H}-6,85-87$ & 43.15 & 8.9 & 50.1 & 41.0 & 1.2 & 0.2 & 5.2 & 5.4 & 0 & 0.2 & 3.3 & 3.5 & 0 & 0.25 & 0.23 & 53.9 \\
\hline $5 \mathrm{H}-6,110-112$ & 43.40 & & & & & 0 & 3.2 & 3.2 & 0 & 0 & 1.8 & 1.8 & 0 & 0.21 & 0.26 & 59.4 \\
\hline $5 \mathrm{H}-6,135-137$ & 43.65 & 2.6 & 42.5 & 54.9 & 0.8 & 0.2 & 2.2 & 2.4 & 0 & 0 & 0.6 & 0.6 & 0 & 0.29 & 0.22 & 59.0 \\
\hline $6 \mathrm{H}-1,85-87$ & 45.15 & 8.9 & 52.4 & 38.7 & 1.4 & 0 & 3.7 & 3.7 & 0 & 0.2 & 4.9 & 5.1 & 0.2 & 0.34 & 0.21 & 55.7 \\
\hline $6 \mathrm{H}-1,110-112$ & 45.40 & 5.0 & 58.0 & 37.0 & 1.6 & 0 & 3.6 & 3.6 & 0 & 0.1 & 1.3 & 1.4 & 0 & 0.28 & 0.19 & 58.4 \\
\hline $6 \mathrm{H}-1,135-137$ & 45.65 & 2.8 & 53.7 & 43.5 & 1.2 & 0 & 2.7 & 2.7 & 0 & 0 & 0.3 & 0.3 & 0 & 0.19 & 0.28 & 55.5 \\
\hline $6 \mathrm{H}-2,10-12$ & 45.90 & 6.8 & 52.1 & 41.1 & 1.3 & 0 & 4.0 & 4.0 & 0 & 0 & 1.0 & 1.0 & 0 & 0.18 & 0.23 & 55.4 \\
\hline $6 \mathrm{H}-2,35-37$ & 46.15 & 6.7 & 49.8 & 43.5 & 1.1 & 0.8 & 4.0 & 4.8 & 0 & 0.1 & 2.1 & 2.2 & 0 & & & 57.6 \\
\hline $6 \mathrm{H}-2,60-62$ & 46.40 & 7.6 & 49.4 & 43.0 & 1.1 & 0 & 2.2 & 2.2 & 0 & 0.3 & 5.3 & 5.6 & 0.2 & 0.23 & 0.35 & 54.3 \\
\hline $6 \mathrm{H}-2,85-87$ & 46.65 & 14.2 & 47.9 & 37.9 & 1.3 & 0.1 & 6.5 & 6.6 & 0 & 0.5 & 6.9 & 7.4 & 0.1 & 0.33 & 0.17 & 55.3 \\
\hline $6 \mathrm{H}-2,110-112$ & 46.90 & 5.7 & 62.0 & 32.3 & 1.9 & 0.5 & 3.3 & 3.8 & 0 & 0 & 2.2 & 2.2 & 0 & 0.20 & 0.22 & 60.4 \\
\hline $6 \mathrm{H}-2,135-137$ & 47.15 & 11.1 & 54.0 & 34.9 & 1.5 & 0.8 & 3.6 & 4.4 & 0 & 0.5 & 5.6 & 6.4 & 0.3 & 0.21 & 0.19 & 59.8 \\
\hline $6 \mathrm{H}-3,10-12$ & 47.40 & 7.4 & 57.9 & 34.7 & 1.7 & 0.1 & 2.9 & 3.0 & 0 & 0.2 & 3.8 & 4.0 & 0.1 & 0.15 & 0.19 & 54.8 \\
\hline $6 \mathrm{H}-3,35-37$ & 47.65 & 3.8 & 62.6 & 33.6 & 1.9 & 0.3 & 2.1 & 2.4 & 0 & 0.1 & 1.0 & 1.0 & & 0.37 & 0.40 & 69.3 \\
\hline $6 \mathrm{H}-3,60-62$ & 47.90 & 4.3 & 52.9 & 42.8 & 1.2 & 0 & 2.1 & 2.1 & 0 & 0.1 & 1.8 & 1.9 & 0.1 & 0.23 & 0.23 & 55.1 \\
\hline $6 \mathrm{H}-3,85-87$ & 48.15 & 8.2 & 52.4 & 39.4 & 1.3 & 0.1 & 4.1 & 4.2 & 0 & 0.2 & 3.6 & 3.8 & 0.1 & 0.26 & 0.32 & 59.2 \\
\hline $6 \mathrm{H}-3,110-112$ & 48.40 & 9.6 & 49.2 & 41.2 & 1.2 & 0.3 & 3.7 & 4.0 & 0 & 0.3 & 4.7 & 5.0 & 0.1 & 0.26 & 0.24 & 54.7 \\
\hline $6 \mathrm{H}-3,135-137$ & 48.65 & 7.7 & 56.5 & 35.8 & 1.6 & 0.6 & 4.3 & 4.9 & 0 & 0.1 & 3.0 & 3.1 & 0.2 & 0.27 & 0.22 & 62.4 \\
\hline $6 \mathrm{H}-4,10-12$ & 48.90 & 7.2 & 66.0 & 26.8 & 2.5 & 4.7 & 2.0 & 6.7 & 0 & 0.5 & 0 & 0.5 & & 0.24 & 0.23 & 66.4 \\
\hline $6 \mathrm{H}-4,35-37$ & 49.15 & 7.5 & 63.6 & 28.9 & 2.2 & 2.6 & 4.6 & 7.2 & 0 & 0.2 & 0.1 & 0.3 & & 0.19 & 0.22 & 62.9 \\
\hline $6 \mathrm{H}-4,60-62$ & 49.40 & 10.1 & 58.3 & 31.6 & 1.8 & 0.3 & 6.4 & 6.7 & 0 & 0.4 & 2.9 & 3.3 & 0 & 0.15 & 0.21 & 58.1 \\
\hline $6 \mathrm{H}-4,85-87$ & 49.65 & 10.9 & 56.1 & 33.0 & 1.7 & 1.9 & 3.4 & 5.3 & 0 & 0.5 & 5.0 & 5.5 & 0.3 & 0.19 & 0.23 & 61.2 \\
\hline $6 \mathrm{H}-4,110-112$ & 49.90 & 7.9 & 54.0 & 38.1 & 1.4 & 2.1 & 3.7 & 5.8 & 0 & 0.3 & 1.9 & 2.2 & 0 & 0.19 & 0.20 & 56.3 \\
\hline $6 \mathrm{H}-4,135-137$ & 50.15 & 6.2 & 63.9 & 29.9 & 2.1 & 1.3 & 2.8 & 4.1 & 0 & 0.1 & 1.8 & 1.9 & 0 & 0.18 & 0.24 & 60.7 \\
\hline $6 \mathrm{H}-5,10-12$ & 50.40 & 5.1 & 62.2 & 32.7 & 1.9 & 0.5 & 1.9 & 2.4 & 0 & 0.1 & 2.5 & 2.6 & 0.1 & 0.18 & 0.24 & 59.6 \\
\hline $6 \mathrm{H}-5,60-62$ & 50.90 & 3.6 & 58.4 & 38.0 & 1.5 & 1.2 & 2.4 & 3.6 & 0 & 0 & 0.4 & 0.4 & 0 & 0.14 & 0.21 & 56.4 \\
\hline $6 \mathrm{H}-5,85-87$ & 51.15 & 5.0 & 52.1 & 42.9 & 1.2 & 0.2 & 3.1 & 3.3 & 0 & 0 & 1.7 & 1.7 & 0.1 & 0.16 & 0.20 & 50.0 \\
\hline $6 \mathrm{H}-5,110-112$ & 51.40 & 6.5 & 51.3 & 42.2 & 1.2 & 0.6 & 2.4 & 3.0 & 0 & 0.3 & 2.6 & 2.9 & 0.1 & 0.13 & 0.26 & 55.9 \\
\hline $6 \mathrm{H}-5,135-137$ & 51.65 & 3.0 & 56.9 & 40.1 & 1.4 & 0.5 & 1.6 & 2.1 & 0 & 0.1 & 0.8 & 0.9 & 0 & 0.23 & 0.20 & 59.1 \\
\hline $6 \mathrm{H}-6,10-12$ & 51.90 & 3.9 & 47.7 & 48.4 & 1.0 & 0.3 & 2.8 & 3.1 & 0 & 0.1 & 0.8 & 0.9 & 0 & 0.22 & 0.17 & 56.9 \\
\hline $6 \mathrm{H}-6,35-37$ & 52.15 & 3.0 & 68.8 & 28.2 & 2.4 & 0.1 & 1.9 & 2.0 & 0 & 0.1 & 0.9 & 1.0 & 0 & 0.26 & 0.16 & 55.7 \\
\hline $6 \mathrm{H}-6,60-62$ & 52.40 & 7.3 & 55.2 & 37.5 & 1.5 & 0.1 & 1.2 & 1.3 & 0 & 0.4 & 5.2 & 5.6 & 0 & 0.21 & 0.20 & 53.2 \\
\hline $6 \mathrm{H}-6,85-87$ & 52.65 & 10.0 & 46.6 & 43.4 & 1.1 & 0.9 & 4.6 & 5.5 & 0 & 0.3 & 4.1 & 4.4 & 0.1 & 0.34 & 0.24 & 53.1 \\
\hline
\end{tabular}


APPENDIX C

Hole 704B Data

\begin{tabular}{|c|c|c|c|c|c|c|c|c|c|c|c|c|c|c|c|}
\hline \multirow[b]{2}{*}{$\begin{array}{l}\text { Core, section, } \\
\text { interval }(\mathrm{cm})\end{array}$} & \multirow[b]{2}{*}{$\begin{array}{l}\text { Depth } \\
\text { (mbsf) }\end{array}$} & \multirow[b]{2}{*}{$\begin{array}{l}\text { Sand } \\
(\%)\end{array}$} & & & & & Sand & fraction co & nponents & (relative \% & & & & & \\
\hline & & & $\begin{array}{l}\text { Silt } \\
(\%)\end{array}$ & $\begin{array}{l}\text { Clay } \\
(\%)\end{array}$ & $\begin{array}{l}\text { Silt/ } \\
\text { clay }\end{array}$ & $\begin{array}{l}\text { Dia- } \\
\text { toms }\end{array}$ & $\begin{array}{l}\text { Radio- } \\
\text { larians }\end{array}$ & $\begin{array}{l}\text { Total } \\
\text { bio- } \\
\text { siliceous }\end{array}$ & $\begin{array}{l}\text { Total } \\
\text { car- } \\
\text { bonate }\end{array}$ & $\begin{array}{l}\text { Detrital/ } \\
\text { volcanic } \\
\text { ash }\end{array}$ & $\begin{array}{l}\text { Authigenic } \\
\text { particles }\end{array}$ & $\begin{array}{l}\text { Foraminifer } \\
\text { preservation } \\
\text { index }\end{array}$ & $\begin{array}{l}\text { Organic } \\
\text { carbon } \\
(\%)\end{array}$ & $\begin{array}{c}\text { Car- } \\
\text { bonate } \\
(\%)\end{array}$ & $\begin{array}{r}\mathrm{H}_{2} \mathrm{O} \\
(\%)\end{array}$ \\
\hline 114-704B- & & & & & & & & & & & & & & & \\
\hline $1 \mathrm{H}-1,10-12$ & 0.10 & & & & & & & & & & & 7.6 & 0.09 & 85.2 & 44.8 \\
\hline $1 \mathrm{H}-1,50-52$ & 0.50 & 17.7 & 64.8 & 17.5 & 3.7 & 0.3 & 8.6 & 8.9 & 8.0 & 1.1 & 0 & 7.6 & 0.49 & 41.3 & 64.5 \\
\hline $1 \mathrm{H}-1,90-92$ & 0.90 & 17.5 & 64.5 & 17.8 & 3.6 & 0.3 & 6.7 & 7.0 & 10.8 & 0.2 & 0 & 7.9 & 0.31 & 63.3 & 62.9 \\
\hline $1 \mathrm{H}-1,130-132$ & 1.30 & 28.4 & 54.5 & 17.1 & 3.2 & 0.3 & 13.2 & 13.5 & 14.3 & 0.5 & 0.2 & 1.6 & 0.26 & 66.3 & 56.8 \\
\hline $1 \mathrm{H}-2,10-12$ & 1.60 & & & & & & & & & & & 1.9 & 0.19 & 50.7 & 62.7 \\
\hline $1 \mathrm{H}-2,50-52$ & 2.00 & 49.2 & 35.8 & 15.0 & 2.4 & 1.0 & 7.8 & 8.8 & 39.7 & 0.5 & 0.1 & 12.5 & 0.45 & 82.7 & 47.8 \\
\hline $1 \mathrm{H}-2,90-92$ & 2.40 & 24.7 & 52.9 & 22.4 & 2.3 & 0.3 & 18.5 & 20.0 & 1.5 & 3.5 & 1.2 & 2.0 & 0.19 & 31.7 & 63.5 \\
\hline $1 \mathrm{H}-2,130-132$ & 2.80 & 32.1 & 46.5 & 21.4 & 2.2 & 0.3 & 14.7 & 15.4 & 23.1 & 2.2 & 1.7 & 2.5 & 0.42 & 44.8 & 62.0 \\
\hline $1 \mathrm{H}-3,10-12$ & 3.10 & 39.6 & 49.4 & 11.0 & 4.5 & 0.4 & 15.2 & 15.6 & 23.1 & 1.2 & 0.1 & 3.1 & 0.10 & 63.8 & 57.1 \\
\hline $1 \mathrm{H}-3,50-52$ & 3.50 & 27.5 & 71.7 & 10.6 & 5.8 & 0.5 & 14.8 & 15.7 & 11.8 & 0.8 & 0 & 2.8 & 0.11 & 50.5 & 62.3 \\
\hline $1 \mathrm{H}-3,90-92$ & 3.90 & 43.3 & 45.4 & 11.3 & 4.0 & 0.4 & 27.1 & 28.0 & 10.8 & 3.4 & 1.1 & 3.0 & 0.45 & 34.1 & 53.2 \\
\hline $1 \mathrm{H}-3,130-132$ & 4.30 & 49.4 & 25.9 & 24.7 & 1.0 & 0.5 & 26.0 & 26.5 & 15.2 & 4.9 & 2.5 & 9.3 & 0.19 & 55.7 & 46.7 \\
\hline $1 \mathrm{H}-4,10-12$ & 4.60 & 35.3 & 53.4 & 11.3 & 4.7 & 0 & 15.8 & 16.1 & 16.1 & 2.1 & 0.7 & 2.8 & 0.23 & 56.1 & 62.5 \\
\hline $1 \mathrm{H}-4,50-52$ & 5.00 & 39.4 & 47.1 & 13.5 & 3.5 & 0 & 26.1 & 26.9 & 10.1 & 1.6 & 0.4 & 3.3 & 0.20 & 50.7 & 60.6 \\
\hline $1 \mathrm{H}-4,90-92$ & 5.40 & 42.2 & 37.2 & 20.6 & 1.8 & 0 & 35.7 & 35.7 & 0 & 4.6 & 1.1 & - & 1.75 & 42.3 & 57.6 \\
\hline $1 \mathrm{H}-4,130-132$ & 5.80 & 9.9 & 53.0 & 37.1 & 1.4 & 0 & 9.0 & 9.1 & 0.7 & 0.1 & 0 & 4.4 & 0.31 & 52.5 & 61.1 \\
\hline $1 \mathrm{H}-5,10-12$ & 6.10 & 16.5 & 5.6 & 77.9 & 0.1 & 0 & 0.5 & 0.5 & 16.3 & 0.2 & 0.5 & 22.5 & 0.18 & 92.1 & 41.7 \\
\hline $1 \mathrm{H}-5,50-52$ & 6.50 & & & & & & & & & & & & 0.03 & 94.6 & 38.7 \\
\hline $2 \mathrm{H}-1,10-12$ & 6.80 & 16.2 & 13.8 & 70.0 & 0.2 & 0 & 1.0 & 1.0 & 14.7 & 0.3 & 0 & 4.8 & 0.00 & 78.4 & 52.1 \\
\hline $2 \mathrm{H}-1,50-52$ & 7.20 & 10.2 & 68.0 & 21.8 & 3.1 & 0 & 8.0 & 8.6 & 1.4 & 0.4 & 0 & 7.2 & 0.21 & 53.5 & 60.8 \\
\hline $2 \mathrm{H}-1,90-92$ & 7.60 & 5.2 & 60.5 & 34.3 & 0.1 & 0 & 1.4 & 1.4 & 3.6 & 0 & 0 & 8.1 & 0.04 & 91.4 & 42.6 \\
\hline $2 \mathrm{H}-1,130-132$ & 8.00 & 12.5 & 25.0 & 62.5 & 0.4 & 0 & 5.6 & 5.7 & 6.0 & 0.3 & 0 & 15.7 & 0.14 & 88.8 & 48.4 \\
\hline $2 \mathrm{H}-2,10-12$ & 8.30 & 5.2 & 60.5 & 34.3 & 1.8 & 0 & 4.9 & 5.0 & 0 & 0 & 0 & - & 0.42 & 12.6 & 77.6 \\
\hline $2 \mathrm{H}-2,50-52$ & 8.70 & 5.0 & 60.5 & 34.5 & 1.8 & 0 & 4.6 & 5.0 & 0 & 0 & 0 & - & 0.55 & 10.0 & 73.4 \\
\hline $2 \mathrm{H}-2,90-92$ & 9.10 & 6.5 & 41.4 & 52.1 & 0.8 & 0 & 6.8 & 6.8 & 0 & 0.2 & 0 & - & 0.76 & 27.6 & 67.0 \\
\hline $2 \mathrm{H}-2,130-132$ & 9.50 & 3.0 & 69.6 & 27.4 & 2.5 & 0 & 2.8 & 2.9 & 0 & 0 & 0 & - & 0.56 & 11.6 & 73.6 \\
\hline $2 \mathrm{H}-3,10-12$ & 9.80 & 2.7 & 69.4 & 27.9 & 2.5 & 0 & 2.9 & 2.9 & 0 & 0 & 0 & - & 0.45 & 8.3 & 75.9 \\
\hline $2 \mathrm{H}-3,50-52$ & 10.20 & 6.1 & 78.7 & 15.2 & 5.2 & 0 & 5.8 & 6.0 & 0 & 0 & 0 & - & 0.34 & 41.0 & 69.2 \\
\hline $2 \mathrm{H}-3,90-92$ & 10.60 & 40.6 & 49.9 & 9.5 & 5.3 & & & & & & & & 0.26 & 44.8 & 64.2 \\
\hline $2 \mathrm{H}-3,130-132$ & 11.00 & 2.7 & 80.8 & 16.5 & 4.9 & 0 & 3.0 & 3.0 & 0 & 0 & 0 & & 4.09 & 31.0 & 74.1 \\
\hline $2 \mathrm{H}-4,90-92$ & 12.10 & 9.2 & 80.1 & 10.7 & 7.6 & 0 & 4.0 & 4.0 & 4.3 & 0.8 & 0 & - & 0.16 & 63.2 & 66.8 \\
\hline $2 \mathrm{H}-4,130-132$ & 12.50 & 9.1 & 78.3 & 12.6 & 6.2 & 0 & 8.0 & 8.2 & 0.1 & 0.5 & 0.2 & & 0.28 & 64.8 & 59.2 \\
\hline $2 \mathrm{H}-5,10-12$ & 12.80 & 4.4 & 69.8 & 25.8 & 2.7 & & & & & & & 0.2 & 0.45 & 16.8 & 72.3 \\
\hline $2 \mathrm{H}-5,50-52$ & 13.20 & 8.4 & 90.4 & 1.2 & 73.3 & 0 & 6.2 & 6.4 & 0 & 1.4 & 0 & 0.2 & 0.48 & 27.7 & 70.7 \\
\hline $2 \mathrm{H}-5,90-92$ & 13.60 & 3.7 & 80.7 & 15.6 & 5.2 & 0 & 3.4 & 3.6 & 0 & 0.3 & 0 & & 0.40 & 45.6 & 67.9 \\
\hline $2 \mathrm{H}-5,130-132$ & 14.00 & 3.6 & 79.0 & 17.4 & 4.5 & 0 & 3.7 & 4.0 & 0 & 0 & 0 & - & 0.35 & 28.5 & 71.4 \\
\hline $2 \mathrm{H}-6,10-12$ & 14.30 & 3.5 & 82.1 & 14.4 & 5.7 & 0.5 & 3.4 & 4.0 & 0 & 0 & 0 & - & 0.18 & 48.6 & 63.3 \\
\hline $3 \mathrm{H}-1,10-12$ & 16.30 & 11.0 & 76.3 & 12.7 & 6.0 & 1.4 & 6.9 & 7.0 & 1.7 & 0.8 & 0 & - & 0.50 & 43.8 & 58.5 \\
\hline $3 \mathrm{H}-1,50-52$ & 16.70 & 18.3 & 72.3 & 9.4 & 7.7 & 2.1 & 10.4 & 13.0 & 4.3 & 0.7 & 0 & - & 0.26 & 60.4 & 53.0 \\
\hline $3 \mathrm{H}-1,90-92$ & 17.10 & 14.2 & 73.6 & 12.2 & 6.0 & 0.8 & 3.2 & 4.2 & 7.8 & 1.8 & 0.2 & 0.5 & 0.20 & 64.3 & 52.2 \\
\hline $3 \mathrm{H}-1,130-132$ & 17.50 & 22.5 & 75.1 & 2.4 & 31.4 & 0.5 & 7.5 & 8.0 & 13.1 & 0.9 & 0 & 2.7 & 0.23 & 66.8 & 54.2 \\
\hline $3 \mathrm{H}-2,50-52$ & 18.20 & 8.6 & 69.8 & 21.6 & 3.2 & 2.6 & 2.2 & 4.9 & 2.9 & 0.2 & 0 & 0.1 & 0.18 & 49.4 & 65.8 \\
\hline $3 \mathrm{H}-2,90-92$ & 18.60 & 7.9 & 71.6 & 20.5 & 3.5 & 1.8 & 2.2 & 4.0 & 3.8 & 0.2 & 0 & 0.6 & 0.33 & 46.6 & 62.4 \\
\hline $3 \mathrm{H}-2,130-132$ & 19.00 & 7.9 & 70.8 & 21.3 & 3.3 & 3.6 & 1.0 & 4.8 & 2.9 & 0.3 & 0 & 0.1 & & & \\
\hline $3 \mathrm{H}-3,10-12$ & 19.30 & 8.4 & 70.4 & 21.2 & 3.3 & 2.7 & 1.0 & 3.8 & 4.0 & 0.2 & 0 & 0.2 & 0.09 & 48.6 & 66.4 \\
\hline $3 \mathrm{H}-3,50-52$ & 19.70 & 12.2 & 69.2 & 18.6 & 3.7 & 5.0 & 1.1 & 6.2 & 5.7 & 0.1 & 0 & 0.4 & 0.10 & 45.2 & \\
\hline $3 \mathrm{H}-3,90-92$ & 20.10 & 8.5 & 73.6 & 17.9 & 4.1 & 3.8 & 1.4 & 5.5 & 3.3 & 0.2 & 0 & 0.1 & 0.02 & 51.2 & 58.0 \\
\hline $3 \mathrm{H}-3,130-132$ & 20.50 & 8.0 & 80.3 & 11.7 & 6.8 & 1.8 & 5.4 & 7.3 & 0.6 & 0.1 & 0 & 0.3 & 0.15 & 59.7 & 54.4 \\
\hline $3 \mathrm{H}-4,10-12$ & 20.80 & 6.4 & 81.5 & 12.1 & 6.8 & 0.9 & 4.1 & 5.2 & 1.5 & 0.3 & 0 & 0.1 & 0.09 & 56.5 & 56.1 \\
\hline $3 \mathrm{H}-4,50-52$ & 21.20 & 10.0 & 77.2 & 12.8 & 6.1 & 0.4 & 6.5 & 7.0 & 2.8 & 0.2 & 0 & 0.3 & 0.19 & 57.2 & 55.4 \\
\hline $3 \mathrm{H}-4,90-92$ & & & & & & & & & & & & 0.1 & 0.16 & 55.2 & 36.4 \\
\hline $3 \mathrm{H}-4,130-132$ & 22.00 & 8.7 & 78.0 & 13.3 & 5.9 & 0 & 6.2 & 6.8 & 2.0 & 0.2 & 0 & 0.5 & 0.35 & 52.9 & 56.1 \\
\hline $3 \mathrm{H}-5,10-12$ & 22.30 & 7.4 & 81.1 & 11.5 & 7.1 & 0 & 4.0 & 4.0 & 2.8 & 0.2 & 0 & & 0.26 & 51.1 & 58.5 \\
\hline $3 \mathrm{H}-5,50-52$ & 22.70 & 8.8 & 78.2 & 13.0 & 6.0 & 0.3 & 4.5 & 5.0 & 3.8 & 0.2 & 0 & 0.5 & 0.25 & 60.0 & 57.3 \\
\hline $3 \mathrm{H}-5,90-92$ & 23.10 & 12.6 & 81.6 & 5.8 & 14.1 & 0 & 2.6 & 2.8 & 9.3 & 0.9 & 0 & 0.3 & 0.23 & 66.1 & 57.8 \\
\hline $3 \mathrm{H}-5,130-132$ & 23.50 & 9.1 & 82.8 & 8.1 & 10.2 & 0 & 4.2 & 4.5 & 4.0 & 0.5 & 0 & 0.1 & 0.16 & 68.4 & 52.6 \\
\hline $3 \mathrm{H}-6,10-12$ & 23.80 & 11.4 & 78.4 & 10.2 & 7.6 & 2.1 & 4.8 & 7.0 & 3.6 & 0.4 & 0 & 0.1 & 0.13 & 65.5 & 58.6 \\
\hline $3 \mathrm{H}-6,50-52$ & 24.20 & 8.5 & 84.1 & 7.4 & 11.5 & 0.9 & 4.6 & 5.9 & 3.6 & 0.3 & 0.2 & 0.1 & 0.33 & 54.2 & 62.4 \\
\hline $3 \mathrm{H}-6,90-92$ & 24.60 & 7.7 & 71.7 & 20.6 & 3.5 & 6.1 & 1.2 & 7.9 & 0 & 0.1 & 0 & 0.2 & 2.10 & 37.5 & 70.0 \\
\hline $3 \mathrm{H}-6,130-132$ & 25.00 & 10.3 & 77.7 & 12.0 & 6.5 & 2.0 & 4.4 & 6.5 & 3.5 & 0 & 0 & 0.1 & 0.18 & 54.5 & 61.7 \\
\hline $3 \mathrm{H}-7,10-12$ & 25.30 & 16.6 & 68.7 & 14.7 & 4.7 & 4.8 & 4.9 & 10.0 & 6.2 & 0.8 & 0 & 0.1 & 0.16 & 55.9 & 57.2 \\
\hline $3 \mathrm{H}-7,50-52$ & & & & & & & & & & & & 0.5 & 0.16 & 45.6 & 63.7 \\
\hline $4 \mathrm{H}-1,22-24$ & & & & & & & & & & & & 0.1 & 0.00 & 66.2 & \\
\hline $4 \mathrm{H}-1,100-102$ & 26.70 & 34.7 & 44.8 & 20.5 & 2.2 & & & & & & & & 0.28 & 45.1 & \\
\hline $4 \mathrm{H}-1,140-142$ & 27.10 & 12.2 & 80.9 & 6.9 & 11.8 & 0.9 & 3.5 & 4.0 & 7.8 & 0.2 & 0 & 1.0 & 0.03 & 34.3 & \\
\hline $4 \mathrm{H}-2,10-12$ & 27.30 & 6.9 & 73.3 & 19.8 & 3.7 & 5.6 & 1.2 & 7.0 & 0 & 0 & 0 & - & & & \\
\hline $4 \mathrm{H}-2,50-52$ & 27.70 & 3.8 & 85.2 & 11.0 & 7.8 & 0.8 & 2.0 & 3.0 & 0.9 & 0.1 & 0 & 0.2 & 0.13 & 35.0 & \\
\hline $4 \mathrm{H}-2,75-77$ & 27.95 & 8.5 & 71.5 & 20.0 & 3.6 & 1.5 & 2.3 & 4.0 & 4.8 & 0.2 & 0 & 0.1 & 0.25 & 37.9 & 65.4 \\
\hline $4 \mathrm{H}-2,100-102$ & 28.20 & 11.8 & 80.4 & 7.8 & 10.4 & 0.9 & 4.8 & 5.8 & 6.0 & 0.2 & 0 & 0.6 & 0.44 & 35.7 & 71.9 \\
\hline $4 \mathrm{H}-3,10-12$ & 28.80 & 13.3 & 71.8 & 14.9 & 4.8 & 10.9 & 1.3 & 12.3 & 0.7 & 0 & 0 & 0.4 & 0.40 & 44.5 & 85.8 \\
\hline $4 \mathrm{H}-3,50-52$ & 29.20 & 10.5 & 80.3 & 9.2 & 8.7 & 1.5 & 7.1 & 9.0 & 2.5 & 0.5 & 0 & 0.1 & 0.21 & 53.3 & 59.4 \\
\hline $4 \mathrm{H}-3,90-92$ & 29.60 & 15.4 & 68.4 & 16.2 & 4.2 & 5.7 & 5.9 & 12.0 & 2.4 & 0.6 & 0 & 0.2 & 0.16 & 39.8 & 67.3 \\
\hline $4 \mathrm{H}-3,130-132$ & 30.00 & 35.3 & 52.2 & 12.5 & 4.2 & 0.4 & 6.7 & 7.3 & 26.5 & 1.0 & 0.2 & 2.5 & 0.14 & 68.8 & 50.8 \\
\hline
\end{tabular}


APPENDIX C

Hole 704B Data

\begin{tabular}{|c|c|c|c|c|c|c|c|c|c|c|c|c|c|c|c|}
\hline \multirow[b]{2}{*}{$\begin{array}{l}\text { Core, section, } \\
\text { interval }(\mathrm{cm})\end{array}$} & \multirow[b]{2}{*}{$\begin{array}{l}\text { Depth } \\
\text { (mbsf) }\end{array}$} & \multirow[b]{2}{*}{$\begin{array}{l}\text { Sand } \\
(\%)\end{array}$} & & & & & Sand & fraction co & mponents & (relative \% & & & & & \\
\hline & & & $\begin{array}{l}\text { Silt } \\
(\%)\end{array}$ & $\begin{array}{l}\text { Clay } \\
(\%)\end{array}$ & $\begin{array}{l}\text { Silt/ } \\
\text { clay }\end{array}$ & $\begin{array}{l}\text { Dia- } \\
\text { toms }\end{array}$ & $\begin{array}{l}\text { Radio- } \\
\text { larians }\end{array}$ & $\begin{array}{l}\text { Total } \\
\text { bio- } \\
\text { siliceous }\end{array}$ & $\begin{array}{c}\text { Total } \\
\text { car- } \\
\text { bonate }\end{array}$ & $\begin{array}{c}\text { Detrital/ } \\
\text { volcanic } \\
\text { ash }\end{array}$ & $\begin{array}{c}\text { Authigenic } \\
\text { particles }\end{array}$ & $\begin{array}{l}\text { Foraminifer } \\
\text { preservation } \\
\text { index }\end{array}$ & $\begin{array}{c}\text { Organic } \\
\text { carbon } \\
(\%)\end{array}$ & $\begin{array}{c}\text { Car- } \\
\text { bonate } \\
(\%)\end{array}$ & $\begin{array}{r}\mathrm{H}_{2} \mathrm{O} \\
(\%)\end{array}$ \\
\hline $4 \mathrm{H}-4,10-12$ & 30.30 & 33.2 & 46.6 & 20.2 & 2.3 & & & & & & & & 0.26 & 48.4 & 63.8 \\
\hline $4 \mathrm{H}-4,50-52$ & 30.70 & 40.6 & 49.6 & 9.8 & 5.1 & 0.4 & 7.0 & 7.8 & 30.8 & 1.2 & 1.2 & 1.4 & 0.05 & 73.2 & 48.1 \\
\hline $4 \mathrm{H}-4,90-92$ & 31.10 & 35.4 & 54.3 & 10.3 & 5.3 & 0.4 & 14.4 & 15.1 & 20.9 & 0 & 0 & 4.7 & 0.10 & 71.4 & 47.2 \\
\hline $4 \mathrm{H}-4,130-132$ & 31.50 & 39.7 & 48.1 & 12.2 & 4.0 & 0 & 7.2 & 7.3 & 31.6 & 0.8 & 0.3 & 2.7 & 0.08 & 71.9 & 47.4 \\
\hline $4 \mathrm{H}-5,10-12$ & 31.80 & 49.3 & 43.6 & 7.1 & 6.2 & 0 & 10.0 & 10.0 & 39.0 & 0 & 0 & 14.9 & 0.07 & 75.7 & 51.6 \\
\hline $4 \mathrm{H}-5,50-52$ & 32.20 & 3.3 & 68.4 & 28.2 & 2.4 & 0 & 2.7 & 3.0 & 0 & 0 & 0 & - & 0.27 & 23.2 & 65.4 \\
\hline $4 \mathrm{H}-5,90-92$ & 32.60 & 29.8 & 58.4 & 11.8 & 5.0 & 0 & 12.0 & 12.0 & 18.0 & 0 & 0 & 2.8 & 0.11 & 68.9 & 53.7 \\
\hline $4 \mathrm{H}-5,130-132$ & 33.00 & 29.4 & 59.8 & 10.8 & 5.6 & 0 & 16.5 & 16.9 & 11.7 & 0.3 & 0.1 & 6.8 & 0.10 & 54.1 & 58.8 \\
\hline $4 \mathrm{H}-6,10-12$ & 33.30 & 5.9 & 68.9 & 25.2 & 2.7 & 0 & 5.4 & 5.6 & 0 & 0.4 & 0 & - & 0.33 & 31.1 & 62.2 \\
\hline $4 \mathrm{H}-6,50-52$ & 33.70 & 7.8 & 69.5 & 22.7 & 3.1 & 0 & 6.5 & 6.6 & 0.7 & 0.7 & 0 & 0.2 & 0.19 & 44.9 & 63.5 \\
\hline $4 \mathrm{H}-6,90-92$ & 34.10 & 26.5 & 55.0 & 18.5 & 3.0 & 13.8 & 3.5 & 17.5 & 7.9 & 1.6 & 0 & 6.3 & 0.20 & 65.3 & 52.9 \\
\hline $5 \mathrm{H}-1,30-32$ & 35.50 & 13.1 & 44.2 & 42.7 & 1.0 & 0 & 11.6 & 11.9 & 0 & 1.1 & 0 & - & 0.78 & 7.2 & 61.8 \\
\hline $5 \mathrm{H}-1,70-72$ & 35.90 & 28.5 & 57.8 & 13.7 & 4.2 & 0 & 6.1 & 6.2 & 21.3 & 0.5 & 0 & 1.5 & 0.17 & 74.7 & 44.0 \\
\hline $5 \mathrm{H}-1,110-112$ & 36.30 & 5.1 & 63.2 & 31.7 & 2.0 & 4.9 & 0.1 & 5.0 & 0 & 0 & 0 & - & 0.08 & 55.8 & 61.7 \\
\hline $5 \mathrm{H}-1,140-142$ & 36.60 & 6.1 & 71.8 & 22.1 & 3.3 & 3.0 & 2.1 & 5.2 & 0 & 0.8 & 0 & - & 0.16 & 36.8 & 71.1 \\
\hline $5 \mathrm{H}-2,30-32$ & 37.00 & & & & & & & & & & & & 0.09 & 64.2 & 57.6 \\
\hline $5 \mathrm{H}-2,70-72$ & 37.40 & 37.3 & 34.4 & 28.3 & 1.2 & 0 & 18.1 & 18.2 & 17.7 & 1.1 & 0 & 4.8 & 0.02 & 57.1 & 61.3 \\
\hline $5 \mathrm{H}-2,110-112$ & 37.80 & 24.0 & 63.0 & 13.0 & 4.8 & 0.5 & 8.9 & 9.5 & 14.0 & 0.5 & 0 & 1.8 & 0.17 & 57.0 & \\
\hline $5 \mathrm{H}-2,145-147$ & 38.15 & 8.1 & 74.6 & 17.3 & 4.3 & 5.1 & 2.6 & 7.9 & 0 & 0.1 & 0 & - & 0.02 & 66.1 & 56.2 \\
\hline $5 \mathrm{H}-3,30-32$ & 38.50 & 37.9 & 51.1 & 11.0 & 4.6 & 1.6 & 23.4 & 25.2 & 11.4 & 1.9 & 0.5 & 3.9 & - & 68.1 & 52.1 \\
\hline $5 \mathrm{H}-3,70-72$ & 38.90 & 58.7 & 21.9 & 19.4 & 1.1 & 1.1 & 10.4 & 11.5 & 47.5 & 0 & 0 & 10.4 & 0.24 & 33.1 & 55.4 \\
\hline $5 \mathrm{H}-3,110-112$ & 39.30 & 18.7 & 62.2 & 19.1 & 3.3 & 0.5 & 10.6 & 11.3 & 6.8 & 0.9 & 0 & 1.5 & 0.29 & 23.5 & 69.1 \\
\hline $5 \mathrm{H}-3,145-147$ & 39.65 & 47.4 & 34.4 & 18.2 & 1.9 & 1.4 & 8.5 & 10.2 & 36.3 & 0.5 & 0 & 9.6 & 0.06 & 55.08 & 75.8 \\
\hline $5 \mathrm{H}-4,30-32$ & 40.00 & 11.1 & 67.2 & 21.7 & 3.1 & 1.2 & 4.2 & 5.4 & 5.6 & 0 & 0 & 0.3 & 0.06 & 52.2 & 58.6 \\
\hline $5 \mathrm{H}-4,70-72$ & 40.40 & 36.5 & 59.1 & 4.4 & 13.4 & 0.4 & 14.4 & 15.0 & 2.7 & 15.8 & 2.5 & 0.1 & 0.09 & 59.7 & 56.1 \\
\hline $5 \mathrm{H}-4,110-112$ & 40.80 & 8.8 & 61.8 & 29.4 & 2.1 & 7.5 & 1.5 & 9.0 & 0 & 0 & 0 & - & 0.16 & 66.7 & 56.3 \\
\hline $5 \mathrm{H}-4,145-147$ & 41.15 & 10.6 & 74.2 & 15.1 & 4.9 & 4.5 & 4.2 & 10.1 & 0.8 & 0.1 & 0 & 1.3 & 0.09 & 74.3 & 55.0 \\
\hline $5 \mathrm{H}-5,30-32$ & 41.50 & 18.3 & 70.6 & 11.1 & 6.4 & 0.2 & 11.3 & 12.5 & 5.5 & 0.2 & 0.5 & 0.9 & 0.24 & 60.5 & 63.4 \\
\hline $5 \mathrm{H}-5,70-72$ & 41.90 & 8.9 & 69.5 & 21.6 & 3.2 & 0.6 & 4.9 & 4.7 & 4.3 & 0.2 & 0.5 & 0.1 & 0.08 & 68.7 & \\
\hline $5 \mathrm{H}-5,110-112$ & 42.30 & 35.7 & 50.3 & 13.8 & 3.6 & 0.4 & 9.0 & 9.5 & 26.2 & 0.3 & 0 & 2.4 & 0.05 & 66.7 & 64.3 \\
\hline $5 \mathrm{H}-5,145-147$ & 42.65 & 12.3 & 75.0 & 12.7 & 5.9 & 0.4 & 4.7 & 5.3 & 6.4 & 0.3 & 0 & 0.1 & 0.35 & 43.3 & 65.2 \\
\hline $5 \mathrm{H}-6,30-32$ & 43.00 & 6.5 & 66.2 & 27.3 & 2.43 & 6.5 & 0.5 & 7.0 & 0 & 0 & 0 & - & 0.41 & 26.33 & 67.4 \\
\hline $5 \mathrm{H}-6,70-72$ & 43.40 & 21.1 & 67.1 & 11.8 & 5.7 & 4.8 & 6.3 & 11.2 & 9.6 & 0.2 & 0 & 1.1 & 0.59 & 17.7 & 72.9 \\
\hline $5 \mathrm{H}-6,110-112$ & 43.80 & 28.6 & 58.1 & 13.3 & 4.4 & 3.4 & 9.3 & 13.6 & 14.8 & 0.6 & 0 & 0.6 & 0.68 & 26.1 & 62.0 \\
\hline $5 \mathrm{H}-6,145-147$ & 44.15 & 4.0 & 46.1 & 49.9 & 0.9 & 2.7 & 1.2 & 4.0 & 0 & 0 & 0 & - & 0.37 & 41.7 & 58.7 \\
\hline $5 \mathrm{H}-7,30-32$ & 44.50 & 5.2 & 62.7 & 32.0 & 2.0 & 3.0 & 1.2 & 4.4 & 0.6 & 0.1 & 0 & 0.1 & 0.12 & 70.5 & 50.5 \\
\hline $6 \mathrm{H}-2,60-62$ & 46.80 & 3.1 & 74.8 & 22.1 & 3.4 & & & & & & & & 0.14 & 32.4 & \\
\hline $6 \mathrm{H}-2,90-92$ & 47.10 & 5.7 & 78.8 & 15.5 & 5.1 & 2.4 & 1.9 & 4.5 & 1.4 & 0.1 & 0 & 0.2 & 0.18 & 31.5 & 65.3 \\
\hline $6 \mathrm{H}-2,130-132$ & 47.50 & 3.4 & 76.5 & 20.1 & 3.8 & 0.1 & 1.9 & 4.5 & 1.4 & 0.1 & 0 & 0.1 & 0.21 & 27.2 & 65.9 \\
\hline $6 \mathrm{H}-3,10-12$ & 47.80 & 4.7 & 80.8 & 14.5 & 5.6 & 0 & 2.8 & 2.8 & 0 & 0.2 & 0 & 0.2 & 0.34 & 28.3 & 66.3 \\
\hline $6 \mathrm{H}-3,50-52$ & 48.20 & 9.3 & 84.1 & 6.6 & 12.9 & 0.4 & 3.7 & 4.2 & 4.7 & 0.1 & 0 & 0.5 & 0.29 & 43.2 & 57.3 \\
\hline $6 \mathrm{H}-3,90-92$ & 48.60 & 8.8 & 65.5 & 25.7 & 2.6 & 7.2 & 1.8 & 9.0 & 0 & 0 & 0 & - & 0.26 & 25.5 & 68.5 \\
\hline $6 \mathrm{H}-3,130-132$ & 49.00 & 13.5 & 74.2 & 12.3 & 6.1 & 1.1 & 4.6 & 5.9 & 6.8 & 0.3 & 0 & 0.5 & 0.05 & 55.1 & 61.4 \\
\hline $6 \mathrm{H}-4,10-12$ & 49.30 & 10.2 & 63.4 & 26.4 & 2.4 & 8.1 & 1.5 & 10.0 & 0 & 0 & 0 & - & 0.01 & 48.9 & 62.8 \\
\hline $6 \mathrm{H}-4,50-52$ & 49.70 & 9.6 & 70.2 & 20.2 & 3.5 & 0.9 & 3.3 & 5.0 & 5.0 & 0.5 & 0 & 0.5 & 0.23 & 34.7 & \\
\hline $6 \mathrm{H}-4,90-92$ & 50.10 & 15.5 & 74.2 & 10.3 & 7.2 & 11.9 & 2.1 & 14.3 & 0.7 & 0 & 0 & 0.2 & 0.49 & 43.5 & 69.5 \\
\hline $6 \mathrm{H}-4,130-132$ & 50.50 & 23.8 & 58.8 & 17.4 & 3.4 & 5.5 & 8.2 & 14.0 & 10.0 & 0 & 0 & 0.9 & 0.07 & 54.8 & 66.7 \\
\hline $6 \mathrm{H}-5,10-12$ & 50.80 & 12.1 & 80.7 & 7.2 & 11.2 & 0.8 & 4.9 & 6.0 & 6.0 & 0 & 0 & 1.1 & 0.31 & 46.2 & 65.4 \\
\hline $6 \mathrm{H}-5,50-52$ & 51.20 & 11.0 & 66.2 & 22.8 & 2.9 & 9.2 & 1.5 & 11.0 & 0 & 0 & 0 & 0.1 & 0.59 & 30.2 & 62.6 \\
\hline $6 \mathrm{H}-5,90-92$ & 51.60 & 3.7 & 77.9 & 18.4 & 4.2 & 3.9 & 0 & 3.9 & 0 & 0 & 0 & - & 0.50 & 20.2 & \\
\hline $6 \mathrm{H}-5,130-132$ & 52.00 & 2.2 & 78.5 & 19.3 & 4.1 & 1.7 & 0.3 & 2.0 & 0 & 0 & 0 & - & 0.37 & 23.9 & 67.9 \\
\hline $6 \mathrm{H}-6,10-12$ & 52.30 & 1.5 & 73.7 & 24.8 & 3.0 & 1.1 & 0.8 & 2.0 & 0 & 0 & 0 & - & 0.97 & 12.8 & 68.9 \\
\hline $6 \mathrm{H}-6,50-52$ & 52.70 & 8.0 & 71.2 & 20.8 & 3.4 & 5.9 & 1.4 & 6.7 & 1.3 & 0 & 0 & 0.9 & 0.57 & 23.3 & 69.3 \\
\hline $6 \mathrm{H}-6,90-92$ & 53.10 & 6.5 & 76.7 & 16.8 & 4.6 & 5.3 & 1.0 & 6.5 & 0.4 & 0.1 & 0 & 0.3 & 0.33 & 32.7 & 68.9 \\
\hline $6 \mathrm{H}-6,130-132$ & 53.50 & 4.5 & 83.1 & 12.4 & 7.1 & 3.8 & 1.1 & 5.0 & 0 & 0 & 0 & - & 0.16 & 62.6 & 60.8 \\
\hline $6 \mathrm{H}-7,10-12$ & 53.80 & 8.7 & 67.0 & 24.3 & 2.8 & 1.9 & 4.0 & 6.2 & 1.7 & 0.8 & 0.3 & 0.1 & 0.19 & 59.0 & 58.6 \\
\hline $6 \mathrm{H}-7,50-52$ & 54.20 & 13.4 & 72.3 & 14.3 & 5.1 & 8.3 & 2.5 & 10.9 & 2.1 & 0 & 0 & 0.2 & 0.11 & 51.2 & 61.1 \\
\hline $6 \mathrm{H}-7,85-87$ & 54.55 & 17.5 & 46.7 & 35.8 & 1.3 & 3.2 & 2.6 & 6.2 & 10.5 & 0.3 & 0 & 0.4 & - & 72.7 & 51.9 \\
\hline $7 \mathrm{H}-1,80-82$ & 55.00 & 5.8 & 85.8 & 8.4 & 10.2 & 0.3 & 1.7 & 2.1 & 3.7 & 0 & 0.2 & 0.6 & 0.39 & 53.2 & 50.7 \\
\hline $7 \mathrm{H}-1,135-137$ & 55.55 & 9.8 & 76.4 & 13.8 & 5.6 & 0 & 2.6 & 2.8 & 6.8 & 0.5 & 0 & 0.5 & 0.02 & 43.5 & 63.0 \\
\hline $7 \mathrm{H}-2,70-72$ & 56.40 & 7.4 & 72.3 & 20.3 & 3.6 & 0 & 4.1 & 4.3 & 3.3 & 0.1 & 0 & 1.2 & 0.28 & 39.7 & 62.5 \\
\hline $7 \mathrm{H}-2,110-112$ & 56.80 & 10.1 & 73.9 & 16.0 & 4.6 & 0.1 & 6.8 & 7.1 & 2.8 & 0.1 & 0 & 0.9 & 0.28 & 42.6 & 60.4 \\
\hline $7 \mathrm{H}-2,140-142$ & 57.10 & & & & & & & & & & & 0.2 & 0.21 & 52.1 & 60.9 \\
\hline $7 \mathrm{H}-3,10-12$ & 57.30 & 14.3 & 64.3 & 21.4 & 3.0 & 3.1 & 5.7 & 8.8 & 5.1 & 0.1 & 0 & 3.5 & 1.53 & 42.7 & 61.0 \\
\hline $7 \mathrm{H}-3,50-52$ & 57.70 & 8.6 & 75.6 & 15.8 & 4.8 & & & & & & & & 0.24 & 37.8 & 68.4 \\
\hline $7 \mathrm{H}-3,90-92$ & 58.10 & 4.1 & 82.9 & 12.9 & 6.4 & 1.1 & 2.0 & 3.3 & 0.7 & 0 & 0 & 0.3 & 0.35 & 28.1 & 66.7 \\
\hline $7 \mathrm{H}-3,130-132$ & 58.50 & 2.9 & 87.2 & 9.9 & 8.9 & 0.4 & 1.5 & 2.1 & 0.9 & 0 & 0 & 0.5 & 0.27 & 21.4 & \\
\hline $7 \mathrm{H}-4,10-12$ & 58.8 & 1.9 & 80.4 & 17.7 & 4.6 & 0.4 & 1.0 & 1.5 & 0.5 & 0 & 0 & 0.2 & 0.65 & 11.1 & 72.9 \\
\hline $7 \mathrm{H}-4,50-52$ & 59.20 & 2.6 & 86.7 & 10.7 & 8.1 & 0.9 & 1.2 & 2.3 & 0.7 & 0 & 0 & 0.2 & 0.31 & 17.7 & 71.1 \\
\hline $7 \mathrm{H}-4,90-92$ & 59.60 & 3.1 & 86.1 & 10.7 & 8.0 & 0.5 & 1.9 & 2.5 & 0.5 & 0 & 0 & 0.2 & 0.35 & 17.9 & 71.2 \\
\hline $7 \mathrm{H}-4,130-132$ & 60.00 & 2.5 & 88.6 & 8.9 & 10.0 & 0.2 & 2.5 & 3.0 & 0 & 0 & 0 & - & 0.31 & 28.2 & 66.9 \\
\hline $7 \mathrm{H}-5,10-12$ & 60.30 & 6.6 & 82.4 & 11.0 & 9.3 & 0.2 & 4.3 & 2.7 & 2.3 & 0.5 & 0 & 0.3 & 0.30 & 55.5 & 56.7 \\
\hline $7 \mathrm{H}-5,50-52$ & 60.70 & 10.8 & 77.1 & 12.1 & 6.4 & 0 & 5.3 & 5.5 & 3.3 & 2.1 & 0.1 & 0.3 & 0.37 & 48.9 & 56.6 \\
\hline $7 \mathrm{H}-5,90-92$ & 61.1 & 10.6 & 75.9 & 13.5 & 5.6 & 0.1 & 3.5 & 3.8 & 7.0 & 0.2 & 0 & 0.1 & 0.58 & 46.8 & 61.2 \\
\hline
\end{tabular}


APPENDIX C

Hole 704B Data

\begin{tabular}{|c|c|c|c|c|c|c|c|c|c|c|c|c|c|c|c|}
\hline \multirow[b]{2}{*}{$\begin{array}{l}\text { Core, section, } \\
\text { interval }(\mathrm{cm})\end{array}$} & \multirow[b]{2}{*}{$\begin{array}{l}\text { Depth } \\
\text { (mbsf) }\end{array}$} & \multirow[b]{2}{*}{$\begin{array}{c}\text { Sand } \\
(\%)\end{array}$} & & & & & Sanc & fraction $\mathrm{cc}$ & mponent & (relative \% & & & & & \\
\hline & & & $\begin{array}{l}\text { Silt } \\
(\%)\end{array}$ & $\begin{array}{l}\text { Clay } \\
(\%)\end{array}$ & $\begin{array}{l}\text { Silt/ } \\
\text { clay }\end{array}$ & $\begin{array}{l}\text { Dia- } \\
\text { toms }\end{array}$ & $\begin{array}{l}\text { Radio- } \\
\text { larians }\end{array}$ & $\begin{array}{l}\text { Total } \\
\text { bio- } \\
\text { siliceous }\end{array}$ & $\begin{array}{c}\text { Total } \\
\text { car- } \\
\text { bonate }\end{array}$ & $\begin{array}{l}\text { Detrital/ } \\
\text { volcanic } \\
\text { ash }\end{array}$ & $\begin{array}{c}\text { Authigenic } \\
\text { particles }\end{array}$ & $\begin{array}{l}\text { Foraminifer } \\
\text { preservation } \\
\text { index }\end{array}$ & $\begin{array}{c}\text { Organic } \\
\text { carbon } \\
(\%)\end{array}$ & $\begin{array}{c}\text { Car- } \\
\text { bonate } \\
(\%)\end{array}$ & $\begin{array}{l}\mathrm{H}_{2} \mathrm{O} \\
(\%)\end{array}$ \\
\hline $7 \mathrm{H}-5,130-132$ & 61.50 & 10.9 & 69.3 & 19.8 & 3.4 & 3.5 & 3.2 & 6.9 & 4.0 & 0.1 & 0 & 0.5 & 0.20 & 39.9 & 70.2 \\
\hline $7 \mathrm{H}-6,10-12$ & 61.80 & 20.8 & 59.7 & 19.5 & 3.1 & 6.5 & 3.4 & 10.2 & 10.4 & 0.4 & 0 & 0.3 & 0.36 & 40.0 & 63.8 \\
\hline $7 \mathrm{H}-6,50-52$ & 62.20 & 13.6 & 52.0 & 34.4 & 1.5 & 10.0 & 2.1 & 12.5 & 1.5 & 0 & 0 & 0.4 & 0.18 & 45.8 & 65.8 \\
\hline $7 \mathrm{H}-6,90-92$ & 62.60 & 24.1 & 58.1 & 17.8 & 3.3 & 2.0 & 5.1 & 7.5 & 16.5 & 0 & 0 & 1.1 & 0.14 & 76.2 & 49.9 \\
\hline $7 \mathrm{H}-6,130-132$ & 63.00 & 4.2 & 81.3 & 14.5 & 5.6 & 0 & 2.1 & 2.2 & 1.8 & 0 & 0 & 0.4 & 0.40 & 35.7 & 64.7 \\
\hline $7 \mathrm{H}-7,10-12$ & 63.30 & 4.0 & 81.8 & 14.2 & 5.8 & 3.4 & 0.5 & 4.0 & 0 & 0 & 0 & - & 0.27 & 25.4 & 67.2 \\
\hline $7 \mathrm{H}-7,50-52$ & 63.70 & 2.5 & 83.8 & 13.7 & 6.1 & 0.6 & 1.0 & 2.0 & 0 & 0 & 0 & - & 0.50 & 17.8 & 67.6 \\
\hline $8 \mathrm{H}-1,10-12$ & 63.80 & 8.8 & 72.6 & 18.6 & 3.9 & 0.4 & 6.1 & 6.7 & 2.3 & 0 & 0 & 0.2 & 0.28 & 53.2 & 56.2 \\
\hline $8 \mathrm{H}-1,50-52$ & 64.20 & 42.2 & 35.0 & 22.8 & 1.5 & 2.1 & 6.3 & 8.4 & 33.6 & 0 & 0 & 7.5 & 0.24 & 69.9 & 53.1 \\
\hline $8 \mathrm{H}-1,90-92$ & 64.60 & 18.0 & 66.0 & 15.9 & 4.1 & 12.8 & 3.0 & 16.0 & 2.0 & 0 & 0 & 3.0 & 0.24 & 48.2 & 60.5 \\
\hline $8 \mathrm{H}-2,50-52$ & 65.36 & 2.4 & 89.2 & 8.4 & 10.7 & 0.5 & 1.5 & 2.0 & 0 & 0 & 0 & - & 0.40 & 9.1 & 66.1 \\
\hline $8 \mathrm{H}-2,75-77$ & 65.61 & 1.5 & 85.8 & 12.7 & 6.8 & 0 & 1.8 & 2.0 & 0 & 0 & 0 & - & 0.37 & 8.8 & 67.0 \\
\hline $8 \mathrm{H}-2,130-132$ & 66.16 & 4.5 & 86.2 & 9.3 & 9.3 & 0 & 2.4 & 2.6 & 1.4 & 0 & 0 & 0.5 & 0.36 & 23.4 & 60.8 \\
\hline $8 \mathrm{H}-3,10-12$ & 66.46 & 2.6 & 88.4 & 9.0 & 9.8 & 0 & 2.9 & 3.0 & 0 & 0 & 0 & - & 0.58 & 11.9 & 69.4 \\
\hline $8 \mathrm{H}-3,50-52$ & 66.86 & 12.0 & 68.0 & 20.0 & 3.5 & 0.2 & 5.0 & 5.4 & 6.5 & 0.1 & 0 & 0.2 & 0.20 & 58.1 & 56.7 \\
\hline $8 \mathrm{H}-3,75-77$ & 67.11 & 3.8 & 87.1 & 9.1 & 9.6 & 2.0 & 1.9 & 3.9 & 0 & 0.1 & 0 & - & 0.52 & 6.6 & 75.1 \\
\hline $8 \mathrm{H}-3,90-92$ & 67.26 & 3.7 & 88.6 & 7.7 & 11.5 & 1.2 & 2.4 & 3.9 & 0 & 0.1 & 0 & & - & 69.3 & 69.3 \\
\hline $8 \mathrm{H}-3,130-132$ & 67.66 & 3.9 & 76.1 & 20.0 & 3.8 & 0.9 & 2.9 & 4.0 & 0 & 0 & 0 & - & 0.30 & 25.2 & 66.7 \\
\hline $8 \mathrm{H}-4,10-12$ & 67.96 & 9.0 & 83.0 & 8.0 & 10.7 & 6.5 & 2.3 & 8.5 & 0.5 & 0 & 0 & 0.1 & 0.18 & 42.0 & 62.7 \\
\hline $8 \mathrm{H}-4,50-52$ & 68.36 & 4.3 & 81.5 & 14.2 & 5.8 & 2.9 & 1.0 & 4.0 & 0 & 0 & 0 & - & 0.43 & 15.2 & 70.1 \\
\hline $9 \mathrm{H}-1,10-12$ & 73.30 & 2.0 & 72.5 & 25.5 & 2.8 & & & & & & & & 0.59 & 17.2 & 66.5 \\
\hline $9 \mathrm{H}-1,50-52$ & 73.70 & 2.5 & 70.6 & 26.9 & 2.6 & 0.2 & 2.6 & 3.0 & 0 & 0 & 0 & - & 0.60 & 12.0 & 65.1 \\
\hline $9 \mathrm{H}-1,90-92$ & 74.10 & 3.0 & 71.2 & 25.8 & 2.8 & 0 & 2.6 & 3.0 & 0 & 0.2 & 0 & - & 0.64 & 20.4 & 66.6 \\
\hline $9 \mathrm{H}-1,130-132$ & 74.50 & 22.6 & 59.0 & 18.3 & 3.2 & 6.2 & 8.0 & 14.3 & 7.5 & 0.5 & 0.7 & 0.8 & 0.50 & 24.6 & 64.4 \\
\hline $9 \mathrm{H}-2,10-12$ & 74.80 & 3.0 & 77.8 & 19.2 & 4.0 & 0.2 & 2.3 & 3.0 & 0 & 0 & 0 & - & 0.52 & 22.7 & 67.8 \\
\hline $9 \mathrm{H}-2,50-52$ & 75.20 & 12.2 & 73.0 & 14.8 & 4.9 & & & & & & & & 0.56 & 26.2 & 66.7 \\
\hline $9 \mathrm{H}-2,90-92$ & 75.60 & 6.7 & 78.0 & 18.3 & 4.3 & 1.6 & 3.2 & 5.0 & 0 & 0 & 0 & 0.1 & & & 65.7 \\
\hline $9 \mathrm{H}-2,130-132$ & 76.00 & 5.2 & 82.7 & 12.3 & 6.9 & 0.5 & 2.5 & 3.2 & 1.8 & 0 & 0 & 0.1 & 0.38 & 34.0 & 64.3 \\
\hline $9 \mathrm{H}-3,10-12$ & 76.30 & 27.3 & 65.6 & 7.1 & 9.3 & 5.1 & 10.0 & 15.3 & 11.7 & 0 & 0 & 0.8 & - & 36.2 & 67.3 \\
\hline $9 \mathrm{H}-3,50-52$ & 76.70 & 6.3 & 82.5 & 11.2 & 7.4 & 1.6 & 2.3 & 4.3 & 1.7 & 0 & 0 & 0.1 & - & 46.2 & 71.4 \\
\hline $9 \mathrm{H}-3,90-92$ & 77.10 & 7.5 & 77.0 & 15.5 & 5.0 & 2.4 & 4.1 & 6.7 & 1.2 & 0.1 & 0 & 0.1 & 0.79 & 40.9 & 67.7 \\
\hline $9 \mathrm{H}-3,130-132$ & 77.50 & 4.6 & 72.5 & 22.9 & 3.2 & 1.2 & 2.5 & 3.9 & 0.9 & 0.2 & 0 & 0.1 & 0.16 & 46.2 & 63.7 \\
\hline $9 \mathrm{H}-4,10-12$ & 77.80 & 5.6 & 74.3 & 20.1 & 3.7 & 4.5 & 1.3 & 6.0 & 0 & 0 & 0 & - & 0.09 & 55.8 & 56.6 \\
\hline $9 \mathrm{H}-4,50-52$ & 78.20 & 5.8 & 72.9 & 21.3 & 3.4 & 5.5 & 0.5 & 6.0 & 0 & 0 & 0 & - & 0.14 & 44.6 & 65.4 \\
\hline $9 \mathrm{H}-4,90-92$ & 78.60 & 7.3 & 80.5 & 12.2 & 6.5 & 4.7 & 2.3 & 7.0 & 0 & 0 & 0 & - & 0.18 & 65.7 & 55.8 \\
\hline $9 \mathrm{H}-4,130-132$ & 79.00 & 4.5 & 83.4 & 12.1 & 6.9 & & & & & & & & 0.20 & 28.7 & 71.1 \\
\hline $9 \mathrm{H}-5,10-12$ & 79.30 & 7.5 & 65.2 & 27.3 & 3.4 & 4.8 & 1.9 & 7.0 & 0 & 0 & 0 & - & 0.20 & 27.3 & 70.1 \\
\hline $9 \mathrm{H}-5,50-52$ & 79.70 & 2.7 & 82.0 & 15.3 & 5.4 & 1.1 & 1.4 & 2.8 & 0 & 0 & 0 & - & 0.28 & 34.3 & 67.1 \\
\hline $9 \mathrm{H}-5,90-92$ & 80.10 & 2.3 & 82.3 & 15.4 & 5.4 & 0.8 & 1.1 & 1.9 & 0 & 0 & 0 & - & 0.24 & 43.7 & 63.9 \\
\hline $9 \mathrm{H}-5,130-132$ & 80.50 & 4.0 & 81.3 & 14.7 & 5.5 & 2.3 & 1.3 & 3.9 & 0 & 0 & 0 & - & 0.12 & 55.0 & 57.6 \\
\hline $9 \mathrm{H}-6,10-12$ & 80.80 & 2.9 & 84.4 & 12.7 & 6.6 & 2.0 & 0.7 & 3.0 & 0 & 0 & 0 & - & 0.21 & 31.5 & 65.2 \\
\hline $9 \mathrm{H}-6,50-52$ & 81.20 & 3.5 & 81.8 & 14.6 & 5.6 & 2.0 & 2.0 & 4.0 & 0 & 0 & 0 & - & 0.33 & 47.2 & 63.2 \\
\hline $9 \mathrm{H}-6,90-92$ & 81.60 & 4.0 & 81.8 & 22.41 & 3.3 & 2.3 & 1.6 & 3.9 & 0 & 0 & 0 & - & 0.15 & 66.2 & 54.5 \\
\hline $9 \mathrm{H}-6,130-132$ & 82.00 & 5.7 & 81.8 & 12.5 & 6.5 & 0.5 & 2.2 & 2.8 & 3.2 & 0 & 0 & 0.1 & 0.10 & 63.0 & 54.2 \\
\hline $9 \mathrm{H}-7,10-12$ & 82.30 & 3.4 & 82.5 & 14.1 & 5.9 & 0.5 & 1.0 & 1.6 & 1.4 & 0 & 0 & 0.1 & 0.17 & 61.0 & 63.7 \\
\hline $9 \mathrm{H}-7,50-52$ & 82.70 & 5.0 & 79.2 & 15.8 & 5.0 & 0.5 & 3.3 & 3.9 & 1.1 & 0 & 0 & 0.3 & 0.29 & 37.9 & 59.9 \\
\hline $10 \mathrm{H}-1,10-12$ & 82.80 & 6.5 & 80.7 & 12.8 & 6.3 & 0 & 4.0 & 4.2 & 2.8 & 0 & 0 & 0.1 & 0.28 & 15.7 & 72.9 \\
\hline $10 \mathrm{H}-1,50-52$ & 83.20 & 2.1 & 88.6 & 9.3 & 9.5 & 0.3 & 1.5 & 2.0 & 0 & 0 & 0 & - & 0.0 & 15.8 & 68.6 \\
\hline $10 \mathrm{H}-1,90-92$ & 83.60 & 1.5 & 89.0 & 9.5 & 9.4 & 0 & 1.7 & 1.9 & 0 & 0.1 & 0 & - & 0.5 & 12.4 & 72.0 \\
\hline $10 \mathrm{H}-1,130-132$ & 84.00 & 1.3 & 87.6 & 11.1 & 7.9 & 0 & 0.8 & 1.0 & 0 & 0 & 0 & - & 0.37 & 11.0 & 70.2 \\
\hline $10 \mathrm{H}-2,10-12$ & 84.30 & 1.7 & 82.8 & 15.5 & 5.3 & 0 & 1.8 & 2.0 & 0 & 0 & 0 & - & 0.31 & 10.7 & 69.6 \\
\hline $10 \mathrm{H}-2,50-52$ & 84.70 & 1.4 & 81.3 & 17.3 & 4.7 & & & & & & & & 0.35 & 11.6 & 68.0 \\
\hline $10 \mathrm{H}-2,90-92$ & 85.10 & 1.6 & 83.8 & 14.6 & 5.8 & 0 & 1.8 & 2.0 & 0 & 0 & 0 & - & 0.18 & 30.6 & 69.1 \\
\hline $10 \mathrm{H}-2,130-132$ & 85.50 & 1.5 & 80.3 & 18.2 & 4.4 & 0.1 & 1.6 & 1.9 & 0 & 0.1 & 0 & - & 0.41 & 11.3 & 70.0 \\
\hline $10 \mathrm{H}-3,10-12$ & 85.80 & 4.3 & 83.4 & 12.3 & 6.8 & 3.3 & 0.7 & 4.0 & 0 & 0 & 0 & - & 0.43 & 10.4 & 70.7 \\
\hline $10 \mathrm{H}-3,50-52$ & 86.20 & 1.9 & 79.1 & 19.0 & 4.2 & 0.2 & 1.6 & 1.9 & 0 & 0 & 0 & - & 0.45 & 11.5 & 67.9 \\
\hline $10 \mathrm{H}-3,90-92$ & 86.60 & 2.1 & 79.8 & 18.1 & 4.4 & 0.1 & 1.8 & 2.0 & 0 & 0 & 0 & - & 0.44 & 10.8 & 69.4 \\
\hline $10 \mathrm{H}-3,130-132$ & 87.00 & 2.1 & 78.8 & 19.1 & 4.1 & 1.6 & 0.4 & 2.0 & 0 & 0 & 0 & - & 1.63 & 8.4 & 65.8 \\
\hline $10 \mathrm{H}-4,10-12$ & 87.30 & 6.5 & 85.2 & 8.3 & 10.3 & 0 & 2.7 & 2.9 & 4.1 & 0 & 0 & 0.1 & 0.03 & 12.2 & 73.8 \\
\hline $10 \mathrm{H}-4,50-52$ & 87.70 & 1.8 & 86.6 & 11.6 & 7.4 & 1.5 & 0.5 & 2.0 & 0 & 0 & 0 & - & 0.35 & 10.2 & 70.1 \\
\hline $10 \mathrm{H}-4,90-92$ & 88.10 & 2.9 & 85.1 & 12.0 & 7.1 & 2.6 & 0.4 & 3.1 & 0 & 0 & 0 & - & 0.15 & 16.2 & 71.5 \\
\hline $10 \mathrm{H}-4,130-132$ & 88.50 & 3.9 & 84.1 & 12.0 & 7.0 & 3.0 & 0.7 & 3.9 & 0 & 0 & 0 & - & 0.10 & 55.2 & 57.8 \\
\hline $10 \mathrm{H}-5,10-12$ & 88.80 & 1.6 & 79.8 & 18.6 & 4.3 & 0.7 & 1.2 & 2.1 & 0 & 0 & 0 & - & 0.12 & 56.1 & 59.2 \\
\hline $10 \mathrm{H}-5,50-52$ & 89.20 & 5.5 & 80.7 & 13.8 & 5.9 & 0.8 & 2.9 & 4.0 & 2.0 & 0 & 0 & 0.3 & 0.13 & 58.7 & 60.6 \\
\hline $10 \mathrm{H}-5,90-92$ & 89.60 & 8.3 & 79.0 & 12.7 & 6.2 & 2.2 & 2.6 & 4.9 & 3.1 & 0 & 0 & 0.9 & 0.17 & 62.7 & 57.3 \\
\hline $10 \mathrm{H}-5,130-132$ & 90.00 & 5.5 & 81.3 & 13.2 & 6.2 & 1.9 & 1.4 & 3.5 & 2.5 & 0 & 0 & 0.2 & 0.24 & 63.1 & 55.6 \\
\hline $10 \mathrm{H}-6,10-12$ & 90.30 & 5.3 & 76.2 & 18.5 & 4.1 & 0.9 & 2.5 & 3.5 & 1.5 & 0 & 0 & 0.2 & 0.31 & 62.3 & 56.2 \\
\hline $10 \mathrm{H}-6,50-52$ & 90.70 & 4.9 & 83.3 & 11.8 & 7.1 & 0.7 & 1.5 & 2.3 & 2.7 & 0 & 0 & 0.1 & 0.0 & 62.4 & 55.7 \\
\hline $10 \mathrm{H}-6,90-92$ & 91.10 & 10.1 & 76.4 & 13.5 & 5.7 & & & & & & & & 0.12 & 39.7 & 66.8 \\
\hline $10 \mathrm{H}-6,130-132$ & 91.50 & 5.6 & 73.4 & 21.0 & 3.5 & 5.5 & 0.5 & 6.0 & 0 & 0 & 0 & - & 0.15 & 21.8 & 74.0 \\
\hline $10 \mathrm{H}-7,10-12$ & 91.80 & 2.4 & 80.0 & 17.6 & 4.6 & 1.4 & 0.5 & 2.0 & 0 & 0 & 0 & - & 0.17 & 13.6 & 71.1 \\
\hline $11 \mathrm{H}-1,10-12$ & 92.30 & 4.0 & 81.2 & 14.8 & 5.5 & 0.3 & 3.6 & 3.9 & 0 & 0 & 0 & - & 0.39 & 7.4 & 69.4 \\
\hline $11 \mathrm{H}-1,90-92$ & 93.10 & 1.6 & 79.8 & 18.6 & 4.3 & 0.2 & 1.7 & 2.1 & 0 & 0 & 0 & - & 0.10 & 6.6 & 69.8 \\
\hline $11 \mathrm{H}-2,10-12$ & 93.80 & 1.8 & 76.9 & 21.3 & 3.6 & 0.1 & 1.8 & 2.0 & 0 & 0 & 0 & - & 0.54 & 7.5 & 70.9 \\
\hline
\end{tabular}


APPENDIX C

Hole 704B Data

\begin{tabular}{|c|c|c|c|c|c|c|c|c|c|c|c|c|c|c|c|}
\hline \multirow[b]{2}{*}{$\begin{array}{l}\text { Core, section, } \\
\text { interval }(\mathrm{cm})\end{array}$} & \multirow[b]{2}{*}{$\begin{array}{l}\text { Depth } \\
\text { (mbsf) }\end{array}$} & \multirow[b]{2}{*}{$\begin{array}{l}\text { Sand } \\
(\%)\end{array}$} & \multirow[b]{2}{*}{$\begin{array}{l}\text { Silt } \\
(\%)\end{array}$} & \multirow[b]{2}{*}{$\begin{array}{l}\text { Clay } \\
(\%)\end{array}$} & \multirow[b]{2}{*}{$\begin{array}{l}\text { Silt/ } \\
\text { clay }\end{array}$} & \multicolumn{6}{|c|}{ Sand fraction components (relative \%) } & \multirow[b]{2}{*}{$\begin{array}{l}\text { Foraminifer } \\
\text { preservation } \\
\text { index }\end{array}$} & \multirow[b]{2}{*}{$\begin{array}{c}\text { Organic } \\
\text { carbon } \\
(\%)\end{array}$} & \multirow[b]{2}{*}{$\begin{array}{c}\text { Car- } \\
\text { bonate } \\
(\%)\end{array}$} & \multirow[b]{2}{*}{$\begin{array}{r}\mathrm{H}_{2} \mathrm{O} \\
(\%)\end{array}$} \\
\hline & & & & & & $\begin{array}{l}\text { Dia- } \\
\text { toms }\end{array}$ & $\begin{array}{l}\text { Radio- } \\
\text { larians }\end{array}$ & $\begin{array}{l}\text { Total } \\
\text { bio- } \\
\text { siliceous }\end{array}$ & $\begin{array}{c}\text { Total } \\
\text { car- } \\
\text { bonate }\end{array}$ & $\begin{array}{c}\text { Detrital/ } \\
\text { volcanic } \\
\text { ash }\end{array}$ & $\begin{array}{c}\text { Authigenic } \\
\text { particles }\end{array}$ & & & & \\
\hline $11 \mathrm{H}-2,90-92$ & 94.60 & 2.0 & 81.6 & 16.4 & 5.0 & 0.1 & 1.8 & 2.0 & 0 & 0 & 0 & - & 0.20 & 7.2 & 73.3 \\
\hline $11 \mathrm{H}-3,10-12$ & 95.30 & 1.6 & 81.8 & 16.6 & 4.9 & 0 & 1.8 & 1.9 & 0 & 0 & 0 & - & 0.09 & 9.0 & 70.8 \\
\hline $11 \mathrm{H}-3,90-92$ & 96.10 & 1.7 & 81.3 & 17.0 & 4.9 & 0 & 1.8 & 1.8 & 0 & 0 & 0 & - & 0.23 & 8.6 & 71.0 \\
\hline $11 \mathrm{H}-4,10-12$ & 96.80 & 8.9 & 76.6 & 14.5 & 5.3 & 0.2 & 8.7 & 8.9 & 0 & 0.1 & 0 & - & 0.18 & 21.2 & 65.4 \\
\hline $11 \mathrm{H}-4,50-52$ & 97.20 & 4.5 & 78.4 & 17.1 & 4.6 & 1.4 & 3.2 & 3.8 & 1.0 & 0 & 0 & 0.1 & 0.30 & 25.3 & 70.2 \\
\hline $11 \mathrm{H}-4,90-92$ & 97.60 & 6.3 & 73.4 & 20.3 & 3.6 & 0.3 & 5.3 & 5.7 & 0 & 0.2 & 0 & - & 0.28 & 25.3 & 67.8 \\
\hline $11 \mathrm{H}-4,130-132$ & 98.00 & 4.3 & 74.1 & 21.6 & 3.5 & 1.6 & 2.4 & 4.0 & 0 & 0 & 0 & - & 0.37 & 29.7 & 66.8 \\
\hline $11 \mathrm{H}-6,50-52$ & 100.20 & 3.3 & 79.7 & 17.0 & 4.7 & 1.5 & 1.3 & 2.9 & 0 & 0 & 0 & - & 0.25 & 35.0 & 66.6 \\
\hline $11 \mathrm{H}-6,90-92$ & 100.60 & 3.4 & 78.1 & 18.5 & 4.2 & 2.3 & 0.7 & 3.1 & 0 & 0 & 0 & - & 0.33 & 19.2 & 69.2 \\
\hline $11 \mathrm{H}-6,130-132$ & 101.00 & 2.9 & 71.9 & 25.2 & 2.9 & 1.0 & 1.9 & 3.0 & 0 & 0.1 & 0 & - & & & 64.7 \\
\hline $11 \mathrm{H}-7,10-12$ & 101.30 & 2.6 & 83.0 & 14.4 & 5.8 & 0.8 & 1.7 & 2.9 & 0 & 0 & 0 & - & 0.20 & 15.7 & 60.4 \\
\hline $11 \mathrm{H}-7,50-52$ & 101.70 & 2.1 & 81.0 & 16.9 & 4.9 & 0.3 & 1.4 & 1.8 & 0 & 0 & 0 & - & 0.25 & 12.7 & 66.7 \\
\hline $12 \mathrm{H}-1,10-12$ & 101.80 & 6.5 & 73.0 & 20.5 & 3.6 & 0.3 & 5.3 & 5.9 & 0.3 & 0 & 0 & 0.4 & 0.13 & 31.0 & 66.0 \\
\hline $12 \mathrm{H}-1,50-52$ & 102.20 & 6.3 & 78.2 & 15.5 & 5.0 & 0.4 & 3.4 & 4.0 & 1.9 & 0.1 & 0 & 0.2 & 0.25 & 33.2 & 65.0 \\
\hline $12 \mathrm{H}-1,90-92$ & 102.60 & 14.0 & 72.2 & 13.8 & 5.2 & 0.4 & 6.6 & 7.1 & 6.4 & 0.4 & 0 & 0.1 & 0.17 & 45.0 & 58.5 \\
\hline $12 \mathrm{H}-1,130-132$ & 103.00 & 7.5 & 77.1 & 15.4 & 5.0 & 4.8 & 2.7 & 8.0 & 0 & 0 & 0 & - & 0.51 & 78.8 & 82.9 \\
\hline $12 \mathrm{H}-2,10-12$ & 103.30 & 5.2 & 81.0 & 13.8 & 5.9 & 0.5 & 2.5 & 3.1 & 1.9 & 0 & 0 & 0.1 & 0.20 & 31.6 & \\
\hline $12 \mathrm{H}-2,50-52$ & 103.70 & 11.4 & 71.7 & 16.9 & 4.3 & 0.6 & 6.8 & 7.7 & 4.2 & 0.1 & 0 & 0.7 & 0.25 & 44.7 & 63.4 \\
\hline $12 \mathrm{H}-2,90-92$ & 104.10 & 3.2 & 78.9 & 17.9 & 4.4 & 0.6 & 1.6 & 2.5 & 0.5 & 0 & 0 & 0.2 & 0.20 & 49.7 & 56.6 \\
\hline $12 \mathrm{H}-2,130-132$ & 104.50 & 2.4 & 79.9 & 17.7 & 4.5 & 0.5 & 1.5 & 2.0 & 0 & 0 & 0 & - & 0.14 & 52.2 & 58.7 \\
\hline $12 \mathrm{H}-3,10-12$ & 104.80 & 1.8 & 54.7 & 65.5 & 0.8 & 0.2 & 1.5 & 1.8 & 0 & 0 & 0 & - & 0.16 & 51.7 & 51.5 \\
\hline $12 \mathrm{H}-3,50-52$ & 105.20 & 4.7 & 76.0 & 19.3 & 3.9 & 0 & 3.6 & 3.7 & 1.2 & 0 & 0 & 0.3 & 0.14 & 77.7 & 41.9 \\
\hline $12 \mathrm{H}-3,90-92$ & 105.60 & 9.8 & 73.9 & 16.3 & 4.5 & 1.8 & 4.6 & 6.3 & 3.7 & 0 & 0 & 0.6 & 0.0 & 66.0 & 49.7 \\
\hline $12 \mathrm{H}-3,130-132$ & 106.00 & 27.1 & 57.0 & 15.9 & 3.6 & & & & & & & & 0.21 & 74.6 & 82.6 \\
\hline $12 \mathrm{H}-4,10-12$ & 106.30 & 8.6 & 75.4 & 16.0 & 4.7 & 0 & 6.0 & 6.2 & 2.7 & 0.1 & 0 & 0.8 & 0.28 & 71.6 & 84.7 \\
\hline $12 \mathrm{H}-4,50-52$ & 106.70 & 5.6 & 77.3 & 17.1 & 4.5 & 0 & 2.8 & 3.0 & 3.0 & 0 & 0 & 0.1 & 0.39 & 73.9 & 84.2 \\
\hline $12 \mathrm{H}-4,90-92$ & 107.10 & 8.0 & 57.5 & 34.5 & 1.7 & 0 & 6.3 & 6.4 & 1.5 & 0.1 & 0 & 1.2 & 0.19 & 62.3 & 46.6 \\
\hline $12 \mathrm{H}-4,130-132$ & 107.50 & 6.0 & 78.0 & 16.0 & 4.9 & 0 & 3.1 & 3.3 & 2.6 & 0.1 & 0 & 0.5 & 0.18 & 35.3 & 68.3 \\
\hline $12 \mathrm{H}-5,10-12$ & 107.80 & 20.0 & 64.0 & 16.0 & 4.3 & 0.4 & 9.0 & 9.5 & 10.5 & 0 & 0 & 1.6 & 0.19 & 63.7 & 50.0 \\
\hline $12 \mathrm{H}-5,50-52$ & 108.20 & 6.8 & 74.1 & 19.1 & 3.9 & 0 & 5.7 & 6.0 & 0.8 & 0.2 & 0 & 0.2 & 0.26 & 50.7 & 50.7 \\
\hline $12 \mathrm{H}-5,90-92$ & 108.60 & 15.4 & 68.9 & 15.7 & 4.4 & 0 & 5.9 & 6.0 & 7.8 & 0.1 & 0.1 & 0.6 & 0.20 & 70.8 & 90.7 \\
\hline $12 \mathrm{H}-5,130-132$ & 109.00 & 10.9 & 73.6 & 15.5 & 4.8 & 0 & 4.4 & 5.0 & 6.0 & 0 & 0 & 0.9 & 0.19 & 55.0 & 653.3 \\
\hline $12 \mathrm{H}-6,10-12$ & 109.30 & 13.3 & 55.3 & 31.4 & 1.1 & 0 & 6.0 & 6.2 & 6.8 & 0 & 0 & 1.3 & 0.20 & 68.9 & 45.1 \\
\hline $12 \mathrm{H}-6,50-52$ & 109.70 & 15.2 & 68.0 & 16.8 & 4.2 & 0.1 & 5.1 & 5.3 & 9.6 & 0.1 & 0 & 1.0 & 0.09 & 73.4 & 44.7 \\
\hline $12 \mathrm{H}-6,90-92$ & 110.10 & 14.3 & 70.0 & 15.7 & 4.5 & 0 & 4.0 & 4.1 & 9.9 & 0 & 0 & 1.3 & 0.13 & 72.7 & 44.0 \\
\hline $12 \mathrm{H}-6,130-132$ & 110.50 & 10.4 & 72.8 & 16.8 & 4.3 & 1.4 & 5.6 & 7.2 & 2.7 & 0.1 & 0 & 0.3 & 1.52 & 61.7 & 49.4 \\
\hline $12 \mathrm{H}-7,10-12$ & 110.80 & 12.7 & 71.9 & 15.4 & 4.7 & 1.7 & 5.1 & 6.9 & 5.9 & 0.1 & 0 & 1.1 & - & 74.6 & 42.5 \\
\hline
\end{tabular}


APPENDIX D

Siliceous Microfossil Abundance In Hole 699A

\begin{tabular}{|c|c|c|c|c|c|c|c|c|c|c|c|}
\hline 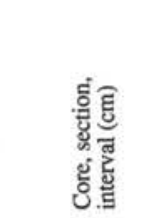 & $\begin{array}{l}\text { है } \\
\text { है } \\
\text { हू } \\
\text { ठू. }\end{array}$ & 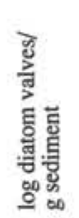 & 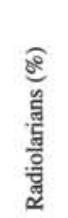 & 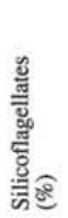 & 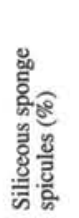 & 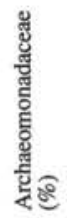 & 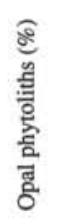 & 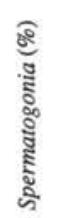 & 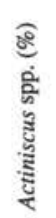 & 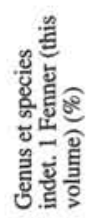 & 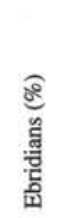 \\
\hline \multicolumn{11}{|l|}{$114-699 \mathrm{~A}-$} & \\
\hline \multirow{19}{*}{$\begin{array}{c}1 \mathrm{H}-1,2 \\
25-27 \\
124-126 \\
127.00 \\
1 \mathrm{H}-2,28-30 \\
60-61 \\
75-77 \\
106-107 \\
146-148 \\
1 \mathrm{H}-3,36-37 \\
72-74 \\
73 \\
124-126 \\
130 \\
1 \mathrm{H}-4,9-10 \\
24-10 \\
75-76 \\
126-128 \\
1 \mathrm{H}-5,25-27 \\
55-56 \\
66 \\
75-77 \\
104-106 \\
131 \\
135-137\end{array}$} & 0.02 & 7.80 & 0.40 & 1.30 & \multirow{10}{*}{$\begin{array}{l}0.00 \\
0.30 \\
0.00 \\
0.30 \\
0.00\end{array}$} & & 0.00 & \multirow{3}{*}{\multicolumn{3}{|c|}{$\begin{array}{l}0.00 \\
0.30 \\
0.00\end{array}$}} & \\
\hline & 0.25 & 8.36 & 0.30 & 1.10 & & 0.00 & 0.30 & & & & \\
\hline & $\begin{array}{l}1.24 \\
1.27\end{array}$ & $\begin{array}{l}8.27 \\
8.10\end{array}$ & $\begin{array}{l}0.30 \\
0.20\end{array}$ & $\begin{array}{l}2.80 \\
1.30\end{array}$ & & $\begin{array}{l}0.30 \\
0.20\end{array}$ & $\begin{array}{l}0.30 \\
0.00\end{array}$ & & & & \\
\hline & 1.78 & 7.97 & 0.30 & 1.50 & & 1.50 & 0.00 & \multicolumn{3}{|l|}{$\begin{array}{l}0.00 \\
0.00\end{array}$} & \\
\hline & 2.10 & 8.15 & 0.00 & 2.00 & & 0.30 & 0.30 & \multirow{2}{*}{\multicolumn{3}{|c|}{$\begin{array}{l}0.00 \\
0.30\end{array}$}} & \\
\hline & 2.25 & 8.07 & 0.00 & 2.00 & & 0.00 & 0.30 & & & & \\
\hline & 2.56 & 8.20 & 0.30 & 1.00 & & 0.00 & 0.00 & 0.00 & & & \\
\hline & $\begin{array}{l}3.36 \\
3.36\end{array}$ & $\begin{array}{l}8.25 \\
7.50\end{array}$ & 0.00 & $\begin{array}{l}1.30 \\
0.00\end{array}$ & & $\begin{array}{l}0.30 \\
1.00\end{array}$ & & $\begin{array}{l}0.00 \\
0.25\end{array}$ & & & \\
\hline & $\begin{array}{l}3.72 \\
3.73\end{array}$ & $\begin{array}{l}7.93 \\
7.50\end{array}$ & $\begin{array}{l}0.00 \\
0.20\end{array}$ & $\begin{array}{l}0.50 \\
0.50\end{array}$ & & 0.60 & 0.00 & & & & \\
\hline & 4.24 & 7.96 & $\begin{array}{l}0.20 \\
0.00\end{array}$ & 0.90 & & $\begin{array}{l}0.00 \\
0.20\end{array}$ & 0.00 & 0.20 & & & \\
\hline & $\begin{array}{r}4.30 \\
460\end{array}$ & 8.30 & 0.00 & 0.00 & 0.00 & 1.30 & & 0.00 & & & \\
\hline & $\begin{array}{l}4.60 \\
4.74\end{array}$ & $\begin{array}{l}7.97 \\
7.99\end{array}$ & $\begin{array}{l}0.00 \\
0.20\end{array}$ & $\begin{array}{l}1.30 \\
1.30\end{array}$ & $\begin{array}{l}0.25 \\
0.20\end{array}$ & $\begin{array}{l}0.50 \\
0.40\end{array}$ & & $\begin{array}{l}0.00 \\
0.20\end{array}$ & & & \\
\hline & 5.25 & 8.20 & 0.50 & 2.20 & 0.00 & 0.10 & & 0.00 & & & \\
\hline & $\begin{array}{l}5.76 \\
6.25\end{array}$ & $\begin{array}{l}8.23 \\
8.01\end{array}$ & $\begin{array}{l}0.30 \\
0.90\end{array}$ & $\begin{array}{l}1.80 \\
1.80\end{array}$ & $\begin{array}{l}0.00 \\
0.30\end{array}$ & $\begin{array}{l}0.00 \\
0.00\end{array}$ & & $\begin{array}{l}0.00 \\
0.30\end{array}$ & & & \\
\hline & 6.55 & 8.20 & 0.00 & 0.00 & 0.00 & $\begin{array}{l}0.00 \\
0.90\end{array}$ & & 0.00 & & & \\
\hline & 6.66 & 7.90 & 0.00 & 0.90 & 0.00 & 0.40 & 0.00 & 0.00 & & & \\
\hline & 6.75 & 7.82 & 0.10 & 0.20 & 0.10 & 2.50 & 0.20 & 0.20 & & & \\
\hline & $\begin{array}{l}7.04 \\
7.31\end{array}$ & $\begin{array}{l}8.00 \\
8.10\end{array}$ & $\begin{array}{l}0.30 \\
0.10\end{array}$ & $\begin{array}{l}2.20 \\
2.20\end{array}$ & 0.00 & $\begin{array}{l}0.20 \\
0.10\end{array}$ & 0.00 & $\begin{array}{l}0.00 \\
0.00\end{array}$ & & & \\
\hline & 7.35 & 8.21 & 0.30 & $\begin{array}{l}2.20 \\
1.50\end{array}$ & 0.00 & $\begin{array}{l}0.100 \\
1.00\end{array}$ & 0.40 & 0.30 & & & \\
\hline $1 \mathrm{H}-6,6-7$ & 7.55 & 7.79 & 0.90 & 1.50 & 0.30 & 0.30 & 0.30 & 0.00 & & & \\
\hline 35-37 & 7.85 & 8.29 & 0.30 & 1.30 & 0.30 & 0.00 & 0.00 & 0.00 & & & \\
\hline $75-76$ & 8.35 & 8.00 & 0.40 & 1.10 & 0.00 & 0.40 & 0.00 & 0.00 & & & \\
\hline $\begin{array}{l}1 \mathrm{H}-\mathrm{CC} \\
2 \mathrm{H}-1,74-75\end{array}$ & $\begin{array}{l}8.60 \\
9.34\end{array}$ & 820 & 0.00 & 2.20 & & 0.30 & 0.60 & 0.30 & & & \\
\hline $2 \mathrm{H}-2,15.5$ & $\begin{array}{l}7.34 \\
10.25\end{array}$ & $\begin{array}{l}8.60 \\
7.60\end{array}$ & $\begin{array}{l}0.30 \\
1.40\end{array}$ & $\begin{array}{l}0.40 \\
2.40\end{array}$ & & 0.00 & 0.00 & & 0.00 & & \\
\hline $15-16$ & 10.26 & 7.67 & 1.40 & 0.35 & & 1.40 & 0.70 & & 0.35 & & \\
\hline $\begin{array}{l}35-37 \\
85-87\end{array}$ & 10.45 & 7.67 & 0.00 & 0.60 & & 1.10 & 0.00 & & 0.00 & & \\
\hline $\begin{array}{l}85-87 \\
142\end{array}$ & $\begin{array}{l}10.95 \\
11.32\end{array}$ & $\begin{array}{l}7.38 \\
7.90\end{array}$ & $\begin{array}{l}1.20 \\
0.00\end{array}$ & $\begin{array}{l}0.00 \\
0.00\end{array}$ & & $\begin{array}{l}0.00 \\
0.40\end{array}$ & & & $\begin{array}{l}0.30 \\
0.00\end{array}$ & & \\
\hline 142,5 & 11.33 & 7.20 & 0.30 & 1.00 & & 0.60 & & 0.00 & & & \\
\hline $\begin{array}{l}144 \\
145\end{array}$ & 11.54 & $\begin{array}{l}7.50 \\
7.30\end{array}$ & 0.00 & 0.00 & & 0.70 & & 0.20 & & & \\
\hline $145-146$ & 11.56 & $\begin{array}{l}7.30 \\
7.50\end{array}$ & $\begin{array}{l}1.20 \\
0.30\end{array}$ & $\begin{array}{l}0.60 \\
0.50\end{array}$ & & $\begin{array}{l}0.00 \\
0.30\end{array}$ & & & & & \\
\hline 147 & 11.57 & 7.80 & 0.30 & 0.00 & & 0.60 & 0.00 & & & & \\
\hline $2 \mathrm{H}-3,34-36$ & 11.94 & 7.48 & 0.60 & 1.20 & & 0.60 & 0.90 & & & & \\
\hline $\begin{array}{l}94-95 \\
127\end{array}$ & 12.54 & 7.70 & 0.00 & 0.70 & & 0.25 & 0.00 & 0.00 & & & \\
\hline $\begin{array}{l}127 \\
136-138\end{array}$ & 12.87 & 7.60 & 0.30 & 1.60 & & 0.00 & 0.00 & 0.30 & & & \\
\hline $\begin{array}{c}136-138 \\
2 \mathrm{H}-4,5-6\end{array}$ & $\begin{array}{l}12.96 \\
13.16\end{array}$ & $\begin{array}{l}7.64 \\
7.28\end{array}$ & $\begin{array}{l}0.40 \\
0.30\end{array}$ & $\begin{array}{l}2.50 \\
1.37\end{array}$ & 0.00 & $\begin{array}{l}0.00 \\
2.75\end{array}$ & $\begin{array}{l}0.30 \\
0.70\end{array}$ & 0.00 & & & \\
\hline $\begin{array}{l}42-44 \\
85\end{array}$ & 13.52 & 8.00 & 0.40 & 2.60 & 0.10 & 0.40 & 0.00 & & 0.00 & & \\
\hline $\begin{array}{l}85 \\
105-106\end{array}$ & $\begin{array}{l}13.95 \\
14.15\end{array}$ & $\begin{array}{l}7.80 \\
7.70\end{array}$ & $\begin{array}{l}0.00 \\
0.00\end{array}$ & $\begin{array}{l}0.90 \\
0.30\end{array}$ & 0.00 & 0.00 & & & 0.40 & & \\
\hline 127 & 14.37 & 7.20 & 0.90 & 0.90 & 0.00 & 0.30 & 1.20 & & 0.00 & & \\
\hline $136-138$ & 14.46 & 7.12 & 0.00 & 1.20 & 0.30 & 1.20 & 0.90 & 0.00 & 0.30 & & \\
\hline $2 \mathrm{H}-5,15-17$ & 14.75 & 7.53 & 0.60 & 3.10 & 0.00 & 0.30 & 1.00 & 0.30 & 0.30 & & \\
\hline $2 \mathrm{H}-\mathrm{CC}$ & 18.10 & 7.45 & 0.30 & 1.80 & 0.00 & 0.00 & 0.00 & 0.30 & 0.00 & & \\
\hline${ }_{35}^{3 \mathrm{H}-1,16-17}$ & 18.26 & 7.57 & 0.45 & 0.45 & 0.00 & 1.30 & 0.45 & 0.00 & & & \\
\hline $\begin{array}{l}35 \\
59-61\end{array}$ & $\begin{array}{l}18.45 \\
18.69\end{array}$ & $\begin{array}{l}7.46 \\
7.53\end{array}$ & $\begin{array}{l}0.90 \\
0.30\end{array}$ & $\begin{array}{l}2.20 \\
1.70\end{array}$ & $\begin{array}{l}0.30 \\
0.00\end{array}$ & $\begin{array}{l}1.20 \\
0.00\end{array}$ & $\begin{array}{l}0.50 \\
0.30\end{array}$ & & & & \\
\hline $106-107$ & 19.16 & 7.60 & 0.60 & 6.60 & 0.00 & 0.20 & 0.00 & 0.00 & & & \\
\hline $\begin{array}{r}144-146 \\
3 \mathrm{H}-2,1-12\end{array}$ & 19.54 & 7.03 & 0.00 & 2.40 & 0.30 & 0.00 & 0.30 & 0.10 & & & \\
\hline $\begin{array}{c}3 \mathrm{H}-2,11-12 \\
45-47\end{array}$ & 19.71 & 7.72 & 0.00 & 2.10 & 0.00 & 0.00 & 0.40 & 0.00 & 0.00 & & \\
\hline $\begin{array}{l}45-47 \\
85-87\end{array}$ & $\begin{array}{l}20.05 \\
20.45\end{array}$ & $\begin{array}{l}7.67 \\
7.46\end{array}$ & 0.00 & $\begin{array}{l}1.50 \\
370\end{array}$ & 0.30 & $\begin{array}{l}0.30 \\
0.60\end{array}$ & $\begin{array}{l}0.30 \\
0.30\end{array}$ & $\begin{array}{l}0.60 \\
0.30\end{array}$ & $\begin{array}{l}0.30 \\
0.30\end{array}$ & & \\
\hline $\begin{array}{l}85-81 \\
130-131\end{array}$ & $\begin{array}{l}20.43 \\
20.90\end{array}$ & $\begin{array}{l}7.46 \\
7.30\end{array}$ & 0.00 & $\begin{array}{l}3.70 \\
2.40\end{array}$ & $\begin{array}{l}0.30 \\
0.30\end{array}$ & $\begin{array}{l}0.60 \\
0.30\end{array}$ & $\begin{array}{l}0.60 \\
0.60\end{array}$ & $\begin{array}{l}0.00 \\
0.00\end{array}$ & $\begin{array}{l}0.30 \\
0.00\end{array}$ & & \\
\hline $3 \mathrm{H}-3,18-19$ & 21.28 & 7.40 & 0.30 & 1.60 & 0.30 & 1.00 & 0.00 & & & & \\
\hline $\begin{array}{l}28 \\
55-57\end{array}$ & 21.38 & 7.82 & 0.30 & 1.30 & 0.00 & 1.60 & 0.30 & & & & \\
\hline $\begin{array}{l}55-57 \\
104-106\end{array}$ & 21.55 & 7.21 & 0.60 & $\begin{array}{l}1.70 \\
360\end{array}$ & $\begin{array}{l}0.30 \\
0.30\end{array}$ & 0.90 & 0.00 & & $\begin{array}{l}0.00 \\
0.30\end{array}$ & & \\
\hline $\begin{array}{l}104-106 \\
124-125\end{array}$ & $\begin{array}{l}22.14 \\
22.35\end{array}$ & $\begin{array}{l}7.51 \\
7.69\end{array}$ & $\begin{array}{l}0.60 \\
030\end{array}$ & $\begin{array}{l}3.60 \\
2.08\end{array}$ & 0.30 & 0.00 & $\begin{array}{l}0.90 \\
0.00\end{array}$ & 0.00 & 0.30 & & \\
\hline $\begin{array}{r}124-125 \\
3 \mathrm{H}-4,15-17\end{array}$ & $\begin{array}{l}22.35 \\
22.75\end{array}$ & $\begin{array}{l}7.69 \\
7.51\end{array}$ & $\begin{array}{l}0.30 \\
0.30\end{array}$ & $\begin{array}{l}2.08 \\
0.60\end{array}$ & & $\begin{array}{l}0.00 \\
0.60\end{array}$ & 0.30 & $\begin{array}{l}0.00 \\
0.30\end{array}$ & 0.00 & & \\
\hline $29-30$ & 22.90 & 7.44 & 0.00 & 1.20 & & 0.90 & 0.30 & 0.00 & 0.30 & & \\
\hline 54 & 23.14 & 7.90 & 0.60 & 0.00 & & 0.60 & 0.10 & 0.10 & 0.00 & & \\
\hline $\begin{array}{l}62-64 \\
126-127\end{array}$ & 23.22 & 7.62 & 0.30 & 0.60 & & 0.60 & 0.00 & 0.00 & & & \\
\hline $\begin{array}{c}126-127 \\
4 \mathrm{H}-1,62\end{array}$ & $\begin{array}{l}23.86 \\
28.22\end{array}$ & $\begin{array}{l}7.50 \\
6.90\end{array}$ & $\begin{array}{l}0.00 \\
0.90\end{array}$ & $\begin{array}{l}0.60 \\
0.60\end{array}$ & $\begin{array}{l}0.00 \\
0.60\end{array}$ & $\begin{array}{l}0.00 \\
0.90\end{array}$ & 0.00 & & & & \\
\hline $108-109$ & 28.68 & 7.40 & 0.00 & $\begin{array}{l}0.00 \\
0.00\end{array}$ & $\begin{array}{l}0.00 \\
1.20\end{array}$ & 0.00 & 0.30 & 0.30 & & & \\
\hline 138-139 & 28.98 & 7.41 & 0.00 & 0.80 & 0.40 & 0.40 & 0.80 & 0.00 & & & \\
\hline $4 \mathrm{H}-2,6-7$ & 29.16 & 6.80 & 0.30 & 0.60 & 0.60 & 1.60 & 0.30 & & & & \\
\hline $61-63$ & 29.71 & 7.44 & 0.00 & 0.00 & 0.60 & 0.30 & 0.30 & & & & \\
\hline $\begin{array}{l}80 \\
109-111\end{array}$ & $\begin{array}{l}29.90 \\
3019\end{array}$ & 6.47 & 0.60 & 000 & 0.00 & 2.50 & 0.60 & & & & \\
\hline $122-123$ & $\begin{array}{l}30.19 \\
30.32\end{array}$ & 7.57 & $\begin{array}{l}0.30 \\
0.35\end{array}$ & 0.70 & & $\begin{array}{l}0.90 \\
2.90\end{array}$ & 0.00 & & & & \\
\hline 143.00 & 30.53 & 6.80 & 1.70 & 0.00 & & 0.90 & 0.00 & & & & \\
\hline $\begin{array}{c}4 \mathrm{H}-3,23-24 \\
59\end{array}$ & 30.83 & 7.63 & 0.10 & 1.70 & & 1.00 & 0.30 & & & & \\
\hline $\begin{array}{l}50-62 \\
60\end{array}$ & $\begin{array}{l}31.19 \\
31.20\end{array}$ & $\begin{array}{l}7.06 \\
7.39\end{array}$ & $\begin{array}{l}1.10 \\
0.60\end{array}$ & $\begin{array}{l}0.40 \\
0.30\end{array}$ & 0.00 & $\begin{array}{l}1.90 \\
1.70\end{array}$ & $\begin{array}{l}0.70 \\
0.60\end{array}$ & & 0.00 & & \\
\hline $109-110$ & 31.70 & 7.02 & 0.65 & 0.30 & 0.30 & 3.26 & 0.65 & 0.30 & 0.30 & & \\
\hline $114-116$ & 31.74 & 6.85 & 0.15 & 0.45 & 0.45 & 5.80 & 0.60 & 0.30 & 0.15 & & \\
\hline $4 \mathrm{H}-4,9-10$ & 32.19 & 7.40 & 0.00 & 0.60 & 0.30 & 0.00 & 0.00 & 0.00 & 0.00 & & \\
\hline $\begin{array}{l}49-51 \\
51\end{array}$ & 32.59 & 6.78 & 0.30 & 1.75 & 0.00 & 7.80 & & & 0.30 & & \\
\hline $\begin{array}{l}51 \\
81-8\end{array}$ & $\begin{array}{l}32.61 \\
32.91\end{array}$ & $\begin{array}{l}6.99 \\
6.43\end{array}$ & $\begin{array}{l}0.35 \\
0.90\end{array}$ & $\begin{array}{l}0.70 \\
3.10\end{array}$ & $\begin{array}{l}0.35 \\
0.00\end{array}$ & $\begin{array}{l}2.10 \\
0.30\end{array}$ & & & 0.00 & $\begin{array}{l}0.00 \\
0.30\end{array}$ & \\
\hline & 32.98 & 735 & 0.30 & 1.80 & & & 0.15 & & & 0.25 & \\
\hline
\end{tabular}




\begin{tabular}{|c|c|c|c|c|c|c|c|c|c|c|c|}
\hline 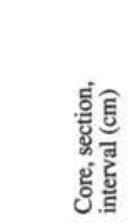 & 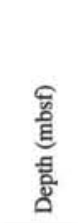 & 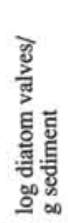 & 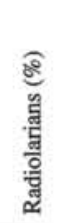 & 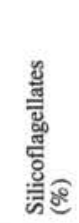 & 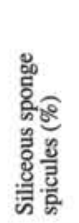 & 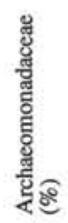 & 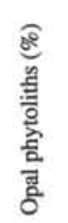 & 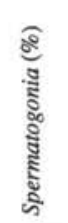 & 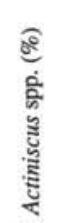 & 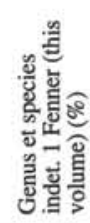 & 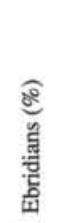 \\
\hline & 33.72 & 6.93 & 0.00 & 2.60 & 0.00 & 0.85 & 0.00 & & & 0.00 & \\
\hline $\begin{array}{l}59-61 \\
109-11\end{array}$ & 34.19 & 7.50 & 0.30 & 0.45 & & 2.60 & 0.30 & & & & 0.00 \\
\hline $\begin{array}{l}109-111 \\
127-128\end{array}$ & $\begin{array}{l}34.69 \\
34.87\end{array}$ & 7.45 & 0.40 & 1.50 & & 0.15 & 0.20 & & & & 0.20 \\
\hline $4 \mathrm{H}-6,2-3$ & $\begin{array}{l}35.87 \\
35.13\end{array}$ & $\begin{array}{l}7.53 \\
7.48\end{array}$ & $\begin{array}{l}0.00 \\
0.80\end{array}$ & $\begin{array}{l}2.25 \\
3.10\end{array}$ & & $\begin{array}{l}2.25 \\
0.80\end{array}$ & $\begin{array}{l}0.45 \\
0.40\end{array}$ & & & & \\
\hline $18-19$ & 35.28 & 7.50 & 0.30 & 2.40 & 0.00 & 0.90 & 0.00 & & 0.00 & & \\
\hline $4 \mathrm{H}-\mathrm{CC}$ & $37.10^{\circ}$ & 7.64 & 0.80 & 1.40 & 0.20 & 0.60 & 0.30 & 0.00 & 0.30 & & \\
\hline $5 \mathrm{H}-1,46-47$ & 37.56 & 7.50 & 0.30 & 2.10 & 0.30 & 0.20 & 0.00 & 0.30 & 0.00 & & \\
\hline 84 & 37.94 & 7.28 & 1.30 & 5.50 & 0.15 & 1.20 & 0.40 & 0.15 & 0.40 & & \\
\hline $\begin{array}{l}140-141 \\
147-148\end{array}$ & 38.51 & 7.55 & 0.35 & 0.35 & 0.35 & 3.25 & 0.00 & 0.00 & 0.00 & & \\
\hline $5 \mathrm{H}-2,75-76$ & 39.35 & 7.38 & 0.30 & $\begin{array}{l}2.00 \\
1.15\end{array}$ & 0.30 & $\begin{array}{l}1.90 \\
0.90\end{array}$ & 0.00 & 0.30 & 0.00 & & \\
\hline $102-104$ & 39.62 & 7.67 & 0.60 & 2.20 & 0.00 & 0.15 & 0.30 & 0.00 & 0.30 & & \\
\hline $130-131$ & 39.90 & 7.97 & 0.40 & 2.55 & 0.00 & 0.00 & 0.00 & & 0.20 & & \\
\hline $5 \mathrm{H}-3,26-27$ & 40.36 & 8.00 & 0.30 & 2.20 & 0.30 & 0.60 & & & 0.00 & & \\
\hline $\begin{array}{l}74-76 \\
77\end{array}$ & $\begin{array}{l}40.84 \\
40.87\end{array}$ & $\begin{array}{l}7.87 \\
8.15\end{array}$ & $\begin{array}{l}0.30 \\
0.00\end{array}$ & $\begin{array}{r}6.40 \\
13.40\end{array}$ & $\begin{array}{l}0.30 \\
0.30\end{array}$ & $\begin{array}{l}0.55 \\
0.30\end{array}$ & & 0.00 & $\begin{array}{l}0.15 \\
0.00\end{array}$ & & \\
\hline $124-126$ & 41.34 & 7.83 & 0.50 & $\begin{array}{r}1.40 \\
4.10\end{array}$ & 0.00 & $\begin{array}{l}0.50 \\
0.50\end{array}$ & & 0.30 & & & 0.00 \\
\hline $\begin{array}{r}130-131 \\
5 \mathrm{H}-4,26-27\end{array}$ & $\begin{array}{l}41.40 \\
41.86\end{array}$ & $\begin{array}{l}7.85 \\
7.92\end{array}$ & $\begin{array}{l}0.40 \\
0.70\end{array}$ & $\begin{array}{l}0.90 \\
0.30\end{array}$ & $\begin{array}{l}0.00 \\
0.30\end{array}$ & $\begin{array}{l}1.10 \\
1.30\end{array}$ & & $\begin{array}{l}0.40 \\
0.30\end{array}$ & & & $\begin{array}{l}0.20 \\
0.00\end{array}$ \\
\hline $75-77$ & 42.35 & 7.91 & 0.30 & 1.10 & 0.00 & 0.30 & & 0.00 & & & \\
\hline $124-126$ & 42.84 & 8.11 & $\begin{array}{l}0.80 \\
0.00\end{array}$ & $\begin{array}{l}1.40 \\
1.40\end{array}$ & & 0.00 & & & 0.00 & & \\
\hline $5 \mathrm{H}-5,26-28$ & 43. & 7.85 & 0 & 0.00 & & 0.30 & & & $\begin{array}{l}0.20 \\
0.00\end{array}$ & & \\
\hline $50-51$ & & 8.00 & 0. & 0.20 & & 1.10 & 0.0 & & 0.00 & & \\
\hline & & 7.95 & 0. & 2.10 & & 1.50 & 0.20 & 0.20 & 0.30 & & \\
\hline & & 7.80 & 0. & 1.80 & 0.00 & 0.60 & 0.00 & 0.00 & 0.00 & & \\
\hline $\begin{array}{r}104-105 \\
6 \mathrm{H}-1,34-35\end{array}$ & $\begin{array}{l}44.15 \\
46.94\end{array}$ & $\begin{array}{l}7.81 \\
7.50\end{array}$ & $\begin{array}{l}0.80 \\
0.20\end{array}$ & $\begin{array}{l}3.30 \\
1.90\end{array}$ & $\begin{array}{l}0.30 \\
0.00\end{array}$ & $\begin{array}{l}3.00 \\
0.00\end{array}$ & & & & & \\
\hline
\end{tabular}

APPENDIX E

Siliceous Microfossil Abundance in Hole 701C

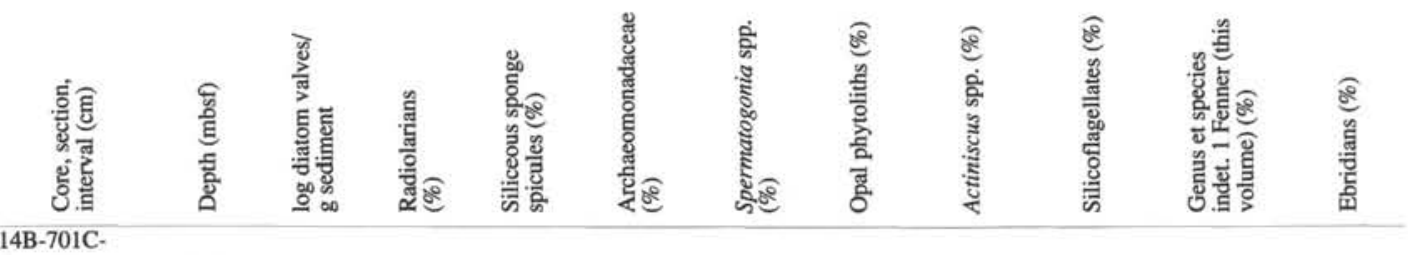

\begin{tabular}{|c|c|c|c|c|c|c|c|c|c|}
\hline $\begin{array}{c}1 \mathrm{H}-1,2-3 \\
15-16 \\
45-46 \\
60-62 \\
75-76 \\
90-91 \\
105-106 \\
120-121 \\
135-136 \\
1 \mathrm{H}-2,2-3 \\
15-16 \\
30-31 \\
45-46 \\
60-61 \\
75-76 \\
90-91 \\
105-106 \\
120-121 \\
135-137 \\
1 \mathrm{H}-3,2-3 \\
15-16 \\
30-31 \\
45-46 \\
60-61 \\
75-76 \\
90-91 \\
105-106 \\
120-121 \\
135-136 \\
1 \mathrm{H}-4,2-3 \\
15-16 \\
30-31 \\
45-46 \\
60-61 \\
75-76 \\
90-91 \\
105-106 \\
120-121 \\
135-137 \\
1 \mathrm{H}-5,2-3 \\
15-16 \\
30-31 \\
45-46 \\
60-61 \\
75-76\end{array}$ & $\begin{array}{l}0.02 \\
0.15 \\
0.45 \\
0.60 \\
0.75 \\
0.90 \\
1.05 \\
1.20 \\
1.35 \\
1.52 \\
1.65 \\
1.80 \\
1.95 \\
2.10 \\
2.25 \\
2.40 \\
2.55 \\
2.70 \\
2.85 \\
3.02 \\
3.15 \\
3.30 \\
3.45 \\
3.60 \\
3.75 \\
3.90 \\
4.05 \\
4.20 \\
4.35 \\
4.52 \\
4.65 \\
4.80 \\
4.95 \\
5.10 \\
5.25 \\
5.40 \\
5.55 \\
5.70 \\
5.85 \\
6.02 \\
6.15 \\
6.30 \\
6.45 \\
6.60 \\
6.75\end{array}$ & $\begin{array}{l}8.05 \\
7.89 \\
8.00 \\
8.12 \\
8.06 \\
7.90 \\
8.14 \\
7.95 \\
7.93 \\
8.04 \\
7.93 \\
8.10 \\
7.97 \\
8.07 \\
8.14 \\
8.24 \\
8.29 \\
8.20 \\
8.14 \\
8.14 \\
8.29 \\
8.08 \\
7.85 \\
7.81 \\
7.86 \\
7.81 \\
8.08 \\
8.09 \\
8.13 \\
8.01 \\
8.13 \\
8.25 \\
7.94 \\
8.03 \\
8.25 \\
7.99 \\
8.20 \\
8.14 \\
8.22 \\
8.45 \\
8.16 \\
8.35 \\
8.18 \\
8.38 \\
8.28\end{array}$ & $\begin{array}{l}0.30 \\
0.74 \\
0.15 \\
0.00 \\
0.10 \\
0.00 \\
0.00 \\
0.10 \\
0.30 \\
0.10 \\
0.30 \\
0.10 \\
0.10 \\
0.00 \\
0.00 \\
0.30 \\
0.30 \\
0.00 \\
\\
0.00 \\
0.15 \\
0.00 \\
0.50 \\
0.00 \\
0.30 \\
0.00 \\
0.50 \\
0.20 \\
0.00\end{array}$ & $\begin{array}{l}0.90 \\
0.92 \\
0.00 \\
0.25 \\
0.10 \\
0.30 \\
0.00 \\
0.28 \\
0.60 \\
0.15 \\
0.60 \\
0.30 \\
1.30 \\
0.80 \\
0.00 \\
0.80 \\
1.40 \\
1.30 \\
2.50 \\
1.20 \\
0.30 \\
1.10 \\
0.30 \\
0.30 \\
0.30 \\
0.00 \\
0.30 \\
0.00 \\
1.30 \\
0.35 \\
2.60 \\
0.75 \\
1.00 \\
0.65 \\
1.60 \\
0.43 \\
2.50 \\
3.50 \\
1.00 \\
0.90 \\
2.06 \\
2.40 \\
0.31 \\
0.38 \\
2.05\end{array}$ & $\begin{array}{l}0.00 \\
0.18 \\
0.15 \\
0.00 \\
0.10 \\
0.32 \\
0.00 \\
0.15 \\
0.00 \\
0.10 \\
0.10 \\
0.10 \\
0.15 \\
0.10 \\
0.00 \\
0.20 \\
0.00\end{array}$ & $\begin{array}{l}0.00 \\
0.35 \\
0.27 \\
0.00 \\
0.25 \\
0.30 \\
0.56 \\
0.28 \\
1.40 \\
1.10 \\
0.30 \\
0.60 \\
0.90 \\
0.80 \\
0.30 \\
0.60 \\
0.60 \\
0.00 \\
0.30 \\
1.20 \\
0.00 \\
0.30 \\
1.20 \\
1.00 \\
0.50 \\
1.00 \\
0.30 \\
0.40 \\
1.10 \\
0.35 \\
0.00 \\
0.40 \\
0.00 \\
\\
0.00 \\
0.80 \\
0.00 \\
0.30 \\
0.60 \\
0.30 \\
0.30 \\
0.00 \\
0.00 \\
\\
0 \\
\end{array}$ & $\begin{array}{l}0.00 \\
0.20 \\
0.00 \\
0.30 \\
0.30 \\
0.50 \\
0.50 \\
0.60 \\
0.20 \\
0.00 \\
0.35 \\
0.00 \\
0.40 \\
0.00 \\
0.30 \\
0.20 \\
0.00 \\
0.40 \\
0.20 \\
0.00 \\
0.40 \\
0.00 \\
0.00 \\
0.60 \\
0.00\end{array}$ & $\begin{array}{l}0.00 \\
0.10 \\
0.25 \\
0.30 \\
0.56 \\
0.00 \\
0.10 \\
0.30 \\
0.30 \\
0.10 \\
0.60 \\
0.50 \\
0.00 \\
\\
0.00 \\
0.15 \\
0.00 \\
0.00 \\
0.30 \\
0.30 \\
0.30 \\
0.00 \\
0.30 \\
0.00 \\
0.30 \\
0.00\end{array}$ & $\begin{array}{l} \\
\\
\\
\\
\\
\\
0.00 \\
0.30 \\
0.00\end{array}$ \\
\hline
\end{tabular}




\begin{tabular}{|c|c|c|c|c|c|c|c|c|c|c|c|}
\hline 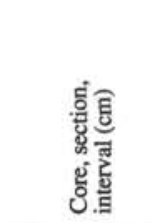 & $\begin{array}{l}\text { : } \\
\text { 苜 } \\
\text { 志 } \\
\text { : }\end{array}$ & 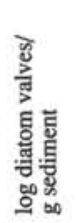 & 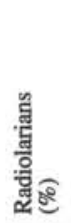 & 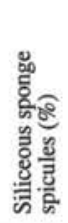 & 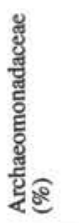 & 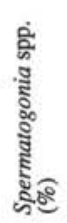 & 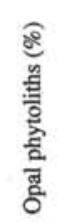 & 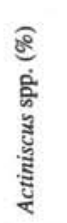 & 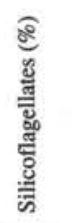 & 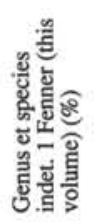 & 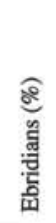 \\
\hline $\begin{array}{l}90-91 \\
105-106\end{array}$ & 6.90 & 8.26 & 0.00 & 0.76 & 0.06 & 0.76 & 0.00 & & & & \\
\hline $\begin{array}{l}105-106 \\
120-121\end{array}$ & 7.05 & 8.21 & 0.10 & 0.88 & 0.58 & 0.30 & 0.30 & & & & \\
\hline $\begin{array}{r}120-121 \\
135-136 \\
1 \mathrm{H}-6,2-3\end{array}$ & 7.20 & $\begin{array}{l}8.48 \\
8.38\end{array}$ & $\begin{array}{l}0.00 \\
0.10\end{array}$ & $\begin{array}{l}0.25 \\
0.30\end{array}$ & 0.00 & $\begin{array}{l}0.50 \\
0.00\end{array}$ & $\begin{array}{l}0.00 \\
0.30\end{array}$ & & & & \\
\hline $\begin{array}{c}1 \mathrm{H}-6,2-3 \\
15-16\end{array}$ & 7.52 & 8.45 & 0.00 & 0.30 & & 0.30 & 0.00 & 0.00 & & & \\
\hline $\begin{array}{l}15-16 \\
30-31\end{array}$ & 7.65 & 8.43 & 0.00 & 0.23 & 0.00 & 0.23 & & 0.23 & 0.00 & & \\
\hline $\begin{array}{l}30-31 \\
45-46\end{array}$ & $\begin{array}{l}7.80 \\
7.95\end{array}$ & $\begin{array}{l}8.44 \\
8.47\end{array}$ & $\begin{array}{l}0.00 \\
0.10\end{array}$ & $\begin{array}{l}0.76 \\
0.70\end{array}$ & 0.25 & 0.76 & & 0.00 & 0.25 & & \\
\hline $60-61$ & 8.10 & 8.18 & 0.00 & 0.45 & $\begin{array}{l}0.00 \\
0.30\end{array}$ & $\begin{array}{l}0.20 \\
0.30\end{array}$ & & 0.00 & & & \\
\hline $\begin{array}{l}75-76 \\
90-91\end{array}$ & $\begin{array}{l}8.25 \\
8.40\end{array}$ & $\begin{array}{l}7.50 \\
7.93\end{array}$ & & $\begin{array}{l}0.30 \\
0.63\end{array}$ & 0.05 & 0.00 & & $\begin{array}{l}0.15 \\
0.00\end{array}$ & & & \\
\hline 105-106 & 8.55 & $\begin{array}{l}1.93 \\
8.20\end{array}$ & & $\begin{array}{l}0.03 \\
1.59\end{array}$ & 0.00 & $\begin{array}{l}0.31 \\
0.31\end{array}$ & & & & & \\
\hline $\begin{array}{l}120-121 \\
135-136\end{array}$ & $\begin{array}{l}8.70 \\
8.85\end{array}$ & 8.35 & & 0.60 & 0.30 & 0.00 & 0.00 & 0.00 & & & \\
\hline $1 \mathrm{H}-7,2-3$ & $\begin{array}{l}8.85 \\
9.02\end{array}$ & $\begin{array}{l}8.42 \\
8.34\end{array}$ & & $\begin{array}{l}0.85 \\
1.40\end{array}$ & 0.00 & $\begin{array}{l}0.50 \\
0.50\end{array}$ & $\begin{array}{l}0.10 \\
0.10\end{array}$ & $\begin{array}{l}0.28 \\
0.05\end{array}$ & & & \\
\hline $\begin{array}{r}15-16 \\
30-31\end{array}$ & 9.15 & 8.53 & & 0.75 & & 0.29 & 0.00 & 0.29 & & & \\
\hline $\begin{array}{r}30-31 \\
45-46\end{array}$ & $\begin{array}{l}9.30 \\
9.45\end{array}$ & 8.11 & 0.00 & $\begin{array}{l}0.80 \\
0.30\end{array}$ & $\begin{array}{l}0.00 \\
0.05\end{array}$ & $\begin{array}{l}1.10 \\
0.30\end{array}$ & $\begin{array}{l}0.60 \\
0.00\end{array}$ & 0.00 & & & \\
\hline $\begin{array}{l}1 \mathrm{H}-\mathrm{CC} \\
2 \mathrm{H}-3,10-12\end{array}$ & 9.65 & 8.13 & 0.10 & 0.29 & 0.00 & 1.10 & 0.29 & & & & \\
\hline $\begin{array}{c}2 \mathrm{H}-3,110-112 \\
135-137\end{array}$ & $\begin{array}{l}10.40 \\
10.65\end{array}$ & 8.14 & $\begin{array}{l}0.26 \\
0.49\end{array}$ & $\begin{array}{l}0.40 \\
0.25\end{array}$ & & 1.26 & 0.00 & 025 & & & \\
\hline $2 \mathrm{H}-4,10-12$ & $\begin{array}{l}10.03 \\
10.90\end{array}$ & 8.33 & $\begin{array}{l}0.49 \\
0.00\end{array}$ & 0.23 & & 0.20 & $\begin{array}{l}0.00 \\
0.05\end{array}$ & 0.23 & & & \\
\hline $\begin{array}{c}35-37 \\
2 \mathrm{H}-5,15-17\end{array}$ & 11.15 & 8.65 & 0.00 & 0.00 & & 0.00 & 0.00 & 0.32 & & & \\
\hline $\begin{array}{c}2 \mathrm{H}-5,15-17 \\
40-42\end{array}$ & $\begin{array}{l}12.45 \\
12.70\end{array}$ & 8.71 & $\begin{array}{l}0.05 \\
0.00\end{array}$ & $\begin{array}{l}0.82 \\
0.30\end{array}$ & 0.00 & 0.15 & 0.00 & 0.00 & & & \\
\hline $\begin{array}{l}40-42 \\
65-67 \\
89-91\end{array}$ & 12.95 & $\begin{array}{l}7.92 \\
7.67\end{array}$ & 0.00 & 0.80 & $\begin{array}{l}0.31 \\
0.27\end{array}$ & $\begin{array}{l}0.31 \\
1.40\end{array}$ & $\begin{array}{l}0.10 \\
0.00\end{array}$ & $\begin{array}{l}0.10 \\
0.15\end{array}$ & & & \\
\hline $\begin{array}{l}89-91 \\
114-116\end{array}$ & $\begin{array}{l}13.19 \\
13.44\end{array}$ & 8.39 & & $\begin{array}{l}1.04 \\
0.60\end{array}$ & 0.24 & 0.00 & 0.20 & 0.00 & & & \\
\hline $\begin{array}{r}140-142 \\
2 \mathrm{H}-6,15-17\end{array}$ & 13.70 & $\begin{array}{l}8.27 \\
8.45\end{array}$ & & 0.30 & $\begin{array}{l}0.58 \\
0.58\end{array}$ & $\begin{array}{l}0.60 \\
0.60\end{array}$ & & & & & \\
\hline $\begin{array}{c}2 \mathrm{H}-6,15-17 \\
40-42\end{array}$ & 13.95 & 8.44 & 0.00 & 0.33 & 0.33 & 0.00 & 000 & & & & \\
\hline $\begin{array}{l}40-42 \\
69-71\end{array}$ & $\begin{array}{l}14.20 \\
14.49\end{array}$ & 8.03 & $\begin{array}{l}0.33 \\
0.47\end{array}$ & $\begin{array}{l}0.65 \\
0.93\end{array}$ & $\begin{array}{l}0.00 \\
0.23\end{array}$ & $\begin{array}{l}0.30 \\
0.93\end{array}$ & $\begin{array}{l}0.00 \\
0.10\end{array}$ & $\begin{array}{l}0.00 \\
0.23\end{array}$ & & & \\
\hline $2 \mathrm{H}-\mathrm{CC}-97$ & 14.75 & 8.50 & 0.00 & 0.85 & 0.28 & 0.28 & 0.20 & 0.00 & & & \\
\hline $3 \mathrm{H}-1,0-2$ & $\begin{array}{l}15.80 \\
15.82\end{array}$ & 8.41 & $\begin{array}{l}0.10 \\
0.00\end{array}$ & $\begin{array}{l}0.80 \\
0.77\end{array}$ & 0.00 & $\begin{array}{l}0.30 \\
0.00\end{array}$ & 0.00 & 0.00 & & & \\
\hline $\begin{array}{l}25-27 \\
50-52\end{array}$ & 16.05 & 8.62 & 0.30 & 1.20 & & 0.60 & & 0.30 & & & \\
\hline $\begin{array}{l}30-32 \\
75-77\end{array}$ & $\begin{array}{l}16.30 \\
16.55\end{array}$ & 8.34 & 0.15 & $\begin{array}{l}0.70 \\
0.45\end{array}$ & 0.00 & $\begin{array}{l}0.23 \\
0.30\end{array}$ & 0.00 & $\begin{array}{l}0.00 \\
0.00\end{array}$ & & & \\
\hline $\begin{array}{l}100-102 \\
125-127\end{array}$ & 16.80 & 7.56 & 0.28 & 0.00 & 0.15 & 1.10 & 0.28 & 0.28 & & & \\
\hline $\begin{array}{l}125-127 \\
147-149\end{array}$ & $\begin{array}{l}17.05 \\
17.27\end{array}$ & $\begin{array}{l}7.55 \\
8.02\end{array}$ & $\begin{array}{l}0.00 \\
0.00\end{array}$ & $\begin{array}{l}0.30 \\
1.14\end{array}$ & $\begin{array}{l}0.60 \\
0.00\end{array}$ & $\begin{array}{l}1.20 \\
0.28\end{array}$ & 0.00 & $\begin{array}{l}0.60 \\
0.00\end{array}$ & & & \\
\hline $3 \mathrm{H}-2,0-2$ & 17.30 & 7.95 & 0.15 & 0.66 & 0.29 & 0.00 & 0.00 & 0.29 & & & \\
\hline $\begin{array}{l}25-27 \\
50-52\end{array}$ & $\begin{array}{l}17.55 \\
1780\end{array}$ & $\begin{array}{l}7.73 \\
8.27\end{array}$ & 0.10 & $\begin{array}{l}0.88 \\
424\end{array}$ & 0.29 & 0.88 & 0.30 & & & & \\
\hline 75-77 & 18.05 & 8.23 & 0.10 & 1.82 & 0.00 & & & & & & \\
\hline $\begin{array}{l}98-100 \\
100-102\end{array}$ & 18.28 & 8.30 & 0.00 & 2.75 & 0.55 & & & & & & \\
\hline $\begin{array}{l}100-102 \\
125-127\end{array}$ & $\begin{array}{l}18.30 \\
18.55\end{array}$ & $\begin{array}{l}8.42 \\
819\end{array}$ & $\begin{array}{l}0.27 \\
0.10\end{array}$ & 1.73 & 0.00 & 0.00 & & & & & \\
\hline $147-149$ & 18.77 & 8.56 & 0.00 & 0.39 & & 0.52 & & 0.00 & & & \\
\hline $3 \mathrm{H}-3,0-2$ & 18.80 & 8.67 & 0.00 & 0.80 & & 0.53 & 0.00 & 0.53 & & & \\
\hline $25-27$ & 19.05 & 8.52 & 0.06 & 1.23 & 0.00 & 0.74 & 0.25 & 0.20 & & & \\
\hline $\begin{array}{l}50-52 \\
75-77\end{array}$ & $\begin{array}{l}19.30 \\
19.55\end{array}$ & $\begin{array}{l}8.76 \\
8.64\end{array}$ & 0.00 & $\begin{array}{l}0.25 \\
0.40\end{array}$ & $\begin{array}{l}0.25 \\
0.00\end{array}$ & $\begin{array}{l}0.00 \\
0.61\end{array}$ & $\begin{array}{l}0.00 \\
0.00\end{array}$ & $\begin{array}{l}0.00 \\
0.20\end{array}$ & 0.00 & & \\
\hline $100-102$ & 19.80 & 8.31 & & 0.23 & & 0.00 & 0.10 & 0.00 & 0.23 & & \\
\hline $125-127$ & 20.05 & 7.74 & & 0.31 & 0.00 & 1.50 & 0.00 & 0.00 & 0.00 & & \\
\hline $147-149$ & 20.27 & 8.27 & 0.00 & 0.40 & 0.20 & 0.59 & & 0.98 & & & \\
\hline $\begin{array}{r}3 \mathrm{H}-4,0-2 \\
25-27\end{array}$ & $\begin{array}{l}20.30 \\
20.55\end{array}$ & $\begin{array}{l}8.34 \\
8.13\end{array}$ & $\begin{array}{l}0.16 \\
0.00\end{array}$ & $\begin{array}{l}0.50 \\
0.00\end{array}$ & $\begin{array}{l}0.00 \\
0.23\end{array}$ & 0.40 & 0.00 & $\begin{array}{l}0.00 \\
0.23\end{array}$ & & & \\
\hline $50-52$ & 20.80 & 7.95 & 0.00 & 0.21 & 0.21 & 0.21 & 0.21 & 0.62 & & & \\
\hline $\begin{array}{l}75-77 \\
99.5\end{array}$ & $\begin{array}{l}21.05 \\
21.29\end{array}$ & $\begin{array}{l}7.68 \\
7.83\end{array}$ & $\begin{array}{l}0.15 \\
0.15\end{array}$ & $\begin{array}{l}0.62 \\
0.81\end{array}$ & $\begin{array}{l}0.31 \\
0.00\end{array}$ & $\begin{array}{l}0.93 \\
2.10\end{array}$ & $\begin{array}{l}0.00 \\
0.00\end{array}$ & $\begin{array}{l}0.31 \\
0.00\end{array}$ & & & \\
\hline $100-102$ & 21.30 & 7.82 & 0.00 & 0.52 & & 2.90 & 0.30 & 0.00 & & & \\
\hline $\begin{array}{l}125-127 \\
147-149\end{array}$ & $\begin{array}{l}21.55 \\
21.77\end{array}$ & $\begin{array}{l}8.08 \\
8.34\end{array}$ & $\begin{array}{l}0.00 \\
0.10\end{array}$ & $\begin{array}{l}0.87 \\
1.21\end{array}$ & $\begin{array}{l}0.00 \\
0.17\end{array}$ & $\begin{array}{l}0.00 \\
0.20\end{array}$ & 0.00 & $\begin{array}{l}0.29 \\
0.17\end{array}$ & & & \\
\hline $3 \mathrm{H}-5,0-2$ & 21.80 & $\begin{array}{l}0.34 \\
8.49\end{array}$ & 0.40 & 0.80 & 0.00 & 0.00 & 0.00 & 0.20 & & & \\
\hline $\begin{array}{l}25-27 \\
50-52\end{array}$ & $\begin{array}{l}22.05 \\
22.30\end{array}$ & $\begin{array}{l}8.58 \\
8.47\end{array}$ & $\begin{array}{l}0.18 \\
0.10\end{array}$ & $\begin{array}{l}0.74 \\
0.97\end{array}$ & & $\begin{array}{l}0.00 \\
0.48\end{array}$ & $\begin{array}{l}0.18 \\
0.00\end{array}$ & $\begin{array}{l}0.15 \\
0.00\end{array}$ & $\begin{array}{l}0.00 \\
0.24\end{array}$ & 0.00 & \\
\hline $75-77$ & 22.55 & 7.56 & 1.07 & 0.41 & 0.00 & 0.22 & 0.21 & 0.21 & 0.00 & 0.21 & \\
\hline $98-100$ & 22.78 & 7.74 & 0.48 & 0.24 & 0.24 & 0.00 & 0.00 & 0.00 & & 0.00 & \\
\hline $\begin{array}{l}125-127 \\
147-149\end{array}$ & $\begin{array}{l}23.05 \\
23.27\end{array}$ & $\begin{array}{l}7.20 \\
7.80\end{array}$ & $\begin{array}{l}0.54 \\
0.10\end{array}$ & $\begin{array}{l}1.08 \\
0.46\end{array}$ & $\begin{array}{l}0.00 \\
0.46\end{array}$ & $\begin{array}{l}0.54 \\
0.00\end{array}$ & $\begin{array}{l}0.54 \\
0.23\end{array}$ & 0.00 & & & \\
\hline $3 \mathrm{H}-6,0-2$ & 23.30 & 7.78 & 0.29 & $\begin{array}{l}0.09 \\
4.09\end{array}$ & 0.58 & 0.00 & 0.00 & $\begin{array}{l}0.00 \\
1.17\end{array}$ & & & \\
\hline $\begin{array}{l}25-27 \\
50-52\end{array}$ & 23.55 & 7.84 & 0.00 & 0.92 & 0.00 & 0.61 & 0.30 & 0.61 & & & \\
\hline $\begin{array}{l}50-52 \\
68\end{array}$ & $\begin{array}{l}23.80 \\
24.00\end{array}$ & $\begin{array}{l}7.86 \\
6.20\end{array}$ & $\begin{array}{l}0.28 \\
0.95\end{array}$ & $\begin{array}{l}2.82 \\
0.00\end{array}$ & $\begin{array}{l}0.85 \\
0.00\end{array}$ & & 0.00 & 0.00 & & & \\
\hline $75-77$ & 24.05 & 8.14 & 0.66 & 2.95 & 0.66 & 0.00 & $\begin{array}{l}0.00 \\
0.30\end{array}$ & & & & \\
\hline $\begin{array}{l}100-102 \\
125-127\end{array}$ & $\begin{array}{l}24.30 \\
24.55\end{array}$ & $\begin{array}{l}7.83 \\
8.08\end{array}$ & $\begin{array}{l}0.24 \\
1.39\end{array}$ & $\begin{array}{l}1.45 \\
2.07\end{array}$ & $\begin{array}{l}0.24 \\
0.23\end{array}$ & $\begin{array}{l}0.24 \\
0.00\end{array}$ & $\begin{array}{l}0.30 \\
0.23\end{array}$ & 0.23 & 0.23 & 0.00 & \\
\hline $\begin{array}{r}147-149 \\
\end{array}$ & 24.77 & 8.18 & 0.27 & 1.60 & 0.00 & 0.20 & 0.00 & 0.00 & 0.00 & 0.20 & \\
\hline $\begin{array}{r}3 \mathrm{H}-7,0-2 \\
25-27\end{array}$ & $\begin{array}{l}24.80 \\
2505\end{array}$ & 8.29 & $\begin{array}{l}0.10 \\
0.82\end{array}$ & $\begin{array}{l}0.89 \\
0.84\end{array}$ & $\begin{array}{l}0.00 \\
0.20\end{array}$ & $\begin{array}{l}0.00 \\
0.00\end{array}$ & & 0.00 & 0.00 & 0.00 & \\
\hline $3 \mathrm{H}-\mathrm{CC}$ & 25.30 & 8.28 & 0.00 & 0.78 & 0.19 & 0.50 & & 0.17 & 0.00 & 0.19 & \\
\hline $4 \mathrm{H}-1,10-12$ & 25.40 & 8.54 & & 2.00 & 0.00 & 0.00 & 0.00 & 0.00 & & 0.00 & \\
\hline $\begin{array}{l}35-37 \\
60-62\end{array}$ & $\begin{array}{l}25.65 \\
25.90\end{array}$ & $\begin{array}{l}7.34 \\
7.78\end{array}$ & $\begin{array}{l}0.00 \\
0.23\end{array}$ & $\begin{array}{l}0.30 \\
1.30\end{array}$ & $\begin{array}{l}0.30 \\
0.00\end{array}$ & & $\begin{array}{l}0.30 \\
0.20\end{array}$ & $\begin{array}{l}0.40 \\
0.23\end{array}$ & & & \\
\hline $85-87$ & 26.15 & 8.16 & 0.28 & 2.94 & 0.28 & & 0.00 & 0.00 & & & \\
\hline $110-112$ & $\begin{array}{l}26.40 \\
26.65\end{array}$ & $\begin{array}{l}8.61 \\
8.38\end{array}$ & 0.00 & $\begin{array}{l}0.73 \\
0.76\end{array}$ & 0.00 & 0.00 & $\begin{array}{l}0.00 \\
0.30\end{array}$ & & $\begin{array}{l}0.00 \\
0.25\end{array}$ & & \\
\hline $85-87$ & 27.65 & 8.36 & 0.00 & 1.04 & 0.00 & 0.40 & 0.20 & 0.00 & 0.00 & & \\
\hline $135-137$ & 28.15 & $\begin{array}{l}0.30 \\
7.12\end{array}$ & 0.45 & 0.15 & 0.75 & 0.45 & 0.90 & 0.25 & 0.25 & & \\
\hline $4 \mathrm{H}-3,10-12$ & 28.40 & 7.72 & 0.30 & 1.08 & 0.59 & 0.00 & 0.40 & 0.00 & 0.00 & & \\
\hline $35-37$ & 28.65 & 7.90 & 0.32 & 0.64 & 0.15 & 0.30 & 0.00 & 0.30 & & & \\
\hline $\begin{array}{l}60-62 \\
85-87\end{array}$ & $\begin{array}{l}28.90 \\
29.15\end{array}$ & $\begin{array}{l}7.37 \\
7.42\end{array}$ & $\begin{array}{l}0.17 \\
0.58\end{array}$ & $\begin{array}{l}0.00 \\
0.29\end{array}$ & $\begin{array}{l}0.43 \\
0.00\end{array}$ & $\begin{array}{l}1.53 \\
0.90\end{array}$ & $\begin{array}{l}0.00 \\
0.29\end{array}$ & $\begin{array}{l}0.00 \\
0.00\end{array}$ & & & \\
\hline
\end{tabular}




\begin{tabular}{|c|c|c|c|c|c|c|c|c|c|c|c|}
\hline 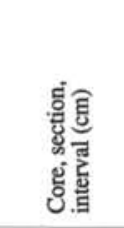 & 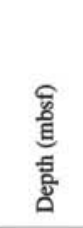 & 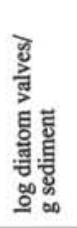 & 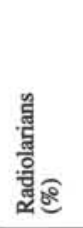 & 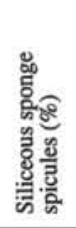 & 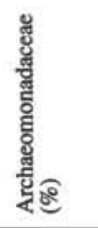 & 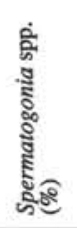 & 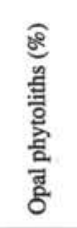 & 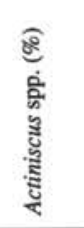 & 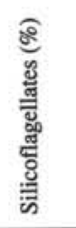 & 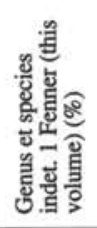 & 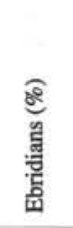 \\
\hline 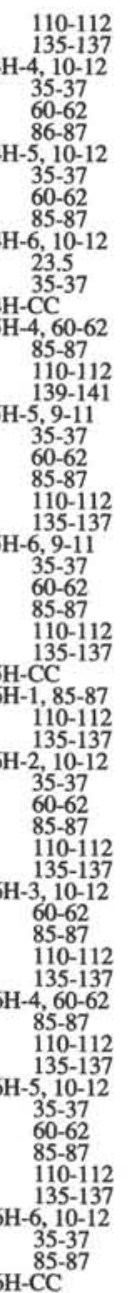 & $\begin{array}{l}29.40 \\
29.65 \\
29.90 \\
30.15 \\
30.40 \\
30.66 \\
31.40 \\
31.65 \\
31.90 \\
32.15 \\
32.90 \\
33.10 \\
33.15 \\
34.80 \\
39.90 \\
40.15 \\
40.40 \\
40.69 \\
40.89 \\
41.15 \\
41.40 \\
41.65 \\
41.90 \\
42.15 \\
42.39 \\
42.65 \\
42.90 \\
43.15 \\
43.40 \\
43.65 \\
44.30 \\
45.15 \\
45.40 \\
45.65 \\
45.90 \\
46.15 \\
46.40 \\
46.65 \\
46.90 \\
47.15 \\
47.40 \\
47.90 \\
48.15 \\
48.40 \\
48.56 \\
49.40 \\
49.65 \\
49.90 \\
50.15 \\
50.40 \\
50.65 \\
50.90 \\
51.15 \\
51.40 \\
51.65 \\
51.90 \\
52.15 \\
52.65 \\
53.80\end{array}$ & $\begin{array}{l}7.70 \\
7.10 \\
7.40 \\
7.59 \\
7.40 \\
7.91 \\
7.55 \\
7.98 \\
7.92 \\
7.93 \\
7.85 \\
7.68 \\
7.82 \\
7.46 \\
7.37 \\
7.64 \\
7.34 \\
7.05 \\
7.66 \\
7.69 \\
7.68 \\
7.00 \\
7.67 \\
7.75 \\
7.82 \\
7.45 \\
7.43 \\
7.61 \\
7.66 \\
7.73 \\
7.52 \\
7.79 \\
7.87 \\
7.72 \\
7.66 \\
7.75 \\
7.47 \\
7.55 \\
7.88 \\
7.72 \\
7.65 \\
7.78 \\
7.66 \\
7.60 \\
7.77 \\
7.98 \\
7.70 \\
7.71 \\
7.80 \\
7.83 \\
7.91 \\
7.78 \\
7.69 \\
7.67 \\
8.05 \\
7.83 \\
7.51 \\
7.52 \\
7.38\end{array}$ & $\begin{array}{l}0.18 \\
0.29 \\
0.26 \\
0.42 \\
0.29 \\
0.10 \\
1.00 \\
0.60 \\
0.20 \\
0.24 \\
0.00 \\
0.30 \\
0.70 \\
0.00 \\
\\
\\
0.00 \\
0.30 \\
0.00 \\
0.30 \\
0.36 \\
0.80 \\
0.01 \\
0.30 \\
0.26 \\
0.00 \\
0.54 \\
0.00 \\
0.00 \\
0.20 \\
1.00 \\
0.00 \\
0.60 \\
0.00 \\
0.00 \\
1.34 \\
0.00 \\
0.30 \\
0.48 \\
0.20 \\
0.28 \\
0.47 \\
0.37 \\
0.00 \\
0.75 \\
0.30 \\
0.30 \\
0.15 \\
0.00 \\
0.36 \\
0.25 \\
0.00 \\
0.30\end{array}$ & $\begin{array}{l}0.28 \\
0.00 \\
0.00 \\
0.46 \\
0.60 \\
0.59 \\
1.52 \\
1.20 \\
0.90 \\
0.49 \\
0.68 \\
1.60 \\
1.40 \\
0.90 \\
3.81 \\
5.44 \\
1.63 \\
1.83 \\
3.40 \\
5.57 \\
1.40 \\
1.58 \\
2.55 \\
5.75 \\
3.46 \\
5.51 \\
3.19 \\
2.17 \\
7.57 \\
3.10 \\
2.15 \\
2.32 \\
2.62 \\
3.87 \\
4.66 \\
0.60 \\
1.65 \\
4.35 \\
0.70 \\
8.60 \\
2.05 \\
1.13 \\
1.95 \\
1.50 \\
2.62 \\
0.94 \\
1.70 \\
3.60 \\
1.75 \\
1.32 \\
1.00 \\
2.40 \\
4.90 \\
2.83 \\
2.50 \\
2.36 \\
1.20\end{array}$ & $\begin{array}{l}0.28 \\
0.00 \\
0.00 \\
0.52 \\
0.29 \\
0.00 \\
0.51 \\
0.30 \\
0.00 \\
\\
0.00 \\
0.30 \\
0.00 \\
0.00 \\
0.00 \\
0.00 \\
0.26 \\
0.00 \\
0.30 \\
0.00\end{array}$ & $\begin{array}{l}2.40 \\
0.70 \\
0.40 \\
1.06 \\
0.30 \\
0.20 \\
0.25 \\
0.00 \\
0.20 \\
0.00 \\
0.00 \\
0.20 \\
0.60 \\
0.70 \\
0.30 \\
0.00 \\
1.63 \\
1.30 \\
1.00 \\
0.60 \\
0.77 \\
2.36 \\
0.36 \\
0.60 \\
0.00 \\
0.00 \\
1.50 \\
0.80 \\
1.45 \\
0.30 \\
0.00 \\
0.60 \\
0.46 \\
0.37 \\
0.70 \\
0.93 \\
0.30 \\
0.55 \\
0.15 \\
0.47 \\
0.38 \\
0.23 \\
0.00 \\
0.00 \\
0.40 \\
0.00 \\
0.37 \\
0.20 \\
0.00 \\
0.00 \\
0.15 \\
1.32 \\
0.18 \\
0.00 \\
1.10 \\
0.18 \\
0.30\end{array}$ & $\begin{array}{l}0.57 \\
0.00 \\
0.00 \\
0.26 \\
0.30 \\
0.20 \\
0.00 \\
0.50 \\
0.00 \\
0.20 \\
0.00 \\
0.00 \\
0.70 \\
0.60 \\
0.00 \\
0.65 \\
1.57 \\
0.70 \\
0.00 \\
0.00 \\
1.35 \\
0.73 \\
0.20 \\
0.00 \\
0.60 \\
0.53 \\
0.35 \\
0.00 \\
0.00 \\
0.30 \\
0.00 \\
0.37 \\
0.35 \\
0.20 \\
0.00 \\
0.00 \\
0.24 \\
0.20 \\
0.00 \\
0.30 \\
0.00 \\
0.20 \\
0.00 \\
0.97 \\
0.42 \\
0.30 \\
0.30 \\
0.50 \\
0.00 \\
0.20 \\
0.40 \\
0.50 \\
0.45 \\
0.30\end{array}$ & $\begin{array}{l}0.03 \\
0.29 \\
0.00 \\
0.00 \\
0.30 \\
0.20 \\
0.51 \\
0.00 \\
0.24 \\
0.23 \\
0.00\end{array}$ & $\begin{array}{l}0.00 \\
0.20 \\
0.00 \\
0.00 \\
0.30 \\
0.30 \\
0.00 \\
0.00 \\
0.26 \\
0.00 \\
0.00 \\
0.25 \\
0.30 \\
\\
\\
0.00 \\
0.53 \\
0.35 \\
0.00 \\
0.60 \\
0.30 \\
0.46 \\
0.00 \\
0.20 \\
0.30 \\
0.00 \\
0.00 \\
0.20 \\
0.23 \\
0.24 \\
0.20 \\
0.00\end{array}$ & $\begin{array}{l}0.00 \\
0.28 \\
0.30 \\
0.00\end{array}$ & $\begin{array}{l}0.00 \\
0.20 \\
0.00 \\
0.00 \\
0.30 \\
0.20 \\
0.00\end{array}$ \\
\hline
\end{tabular}

Siliceous Microfossil Abundance in Hole 704B

\begin{tabular}{|c|c|c|c|c|c|c|c|c|c|c|c|}
\hline 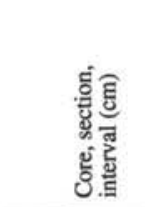 & 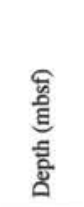 & 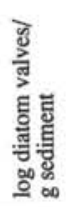 & 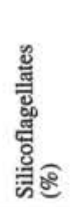 & 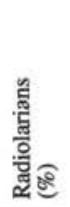 & 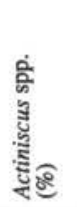 & 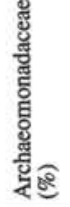 & 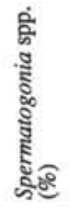 & 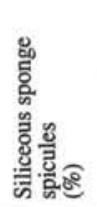 & 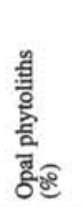 & 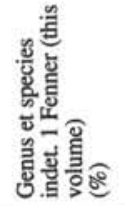 & 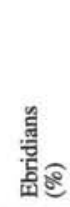 \\
\hline $\begin{array}{c}14-704 \mathrm{~B}- \\
1 \mathrm{H}-1,10-12 \\
50-52 \\
90-92 \\
130-132 \\
1 \mathrm{H}-2,10-12 \\
50-52\end{array}$ & $\begin{array}{l}0.10 \\
0.50 \\
0.90 \\
1.30 \\
1.60\end{array}$ & $\begin{array}{l}6.70 \\
77.80 \\
7.40 \\
7.40 \\
8.10\end{array}$ & $\begin{array}{l}3.20 \\
0.40 \\
0.60 \\
2.00 \\
0.00\end{array}$ & $\begin{array}{l}3.10 \\
1.20 \\
0.60 \\
5.70 \\
1.90\end{array}$ & $\begin{array}{l}0.00 \\
0.20 \\
0.00\end{array}$ & $\begin{array}{l}0.00 \\
0.00 \\
0.10 \\
0.00 \\
0.20\end{array}$ & $\begin{array}{l}0.30 \\
0.00 \\
0.10 \\
0.00 \\
0.0\end{array}$ & $\begin{array}{l}0.60 \\
0.40 \\
0.00 \\
0.40 \\
0.40\end{array}$ & \multirow{2}{*}{$\begin{array}{l}0.00 \\
0.20 \\
0.20 \\
0.05 \\
0.03 \\
0.01 \\
0.00 \\
\\
0.00 \\
0.20 \\
0.00 \\
0.00 \\
0.20\end{array}$} & \multirow[t]{2}{*}{$\begin{array}{l}0.00 \\
0.10 \\
0.00\end{array}$} & \\
\hline $\begin{array}{c}50-52 \\
90-92 \\
100-102 \\
130-132 \\
1 \mathrm{H}-3,50-52 \\
90-92 \\
130-132 \\
1 \mathrm{H}-4,40-12 \\
50-52 \\
90-92\end{array}$ & $\begin{array}{l}2.00 \\
2.40 \\
2.50 \\
2.80 \\
3.50 \\
3.90 \\
4.30 \\
4.60 \\
5.00 \\
5.40\end{array}$ & $\begin{array}{l}7.30 \\
7.80 \\
7.80 \\
8.10 \\
8.00 \\
7.60 \\
7.90 \\
7.70 \\
7.50 \\
7.50\end{array}$ & $\begin{array}{l}2.70 \\
1.00 \\
0.70 \\
0.40 \\
0.30 \\
0.30 \\
0.30 \\
0.10 \\
0.90\end{array}$ & $\begin{array}{l}0.90 \\
1.10 \\
1.40 \\
5.50 \\
1.10 \\
2.10 \\
1.40 \\
2.50 \\
1.50 \\
0.00\end{array}$ & $\begin{array}{l}0.00 \\
0.30 \\
0.00\end{array}$ & $\begin{array}{l}0.00 \\
0.30 \\
0.00 \\
0.10 \\
0.00 \\
0.00 \\
0.20\end{array}$ & $\begin{array}{l}0.00 \\
0.30 \\
0.00 \\
0.00 \\
0.20 \\
0.00\end{array}$ & $\begin{array}{l}0.00 \\
0.30 \\
0.10 \\
0.00 \\
0.00 \\
0.20 \\
0.00 \\
0.20 \\
0.20\end{array}$ & & & \\
\hline
\end{tabular}




\begin{tabular}{|c|c|c|c|c|c|c|c|c|c|c|c|}
\hline 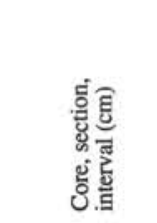 & 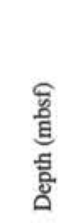 & 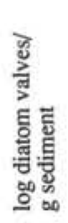 & 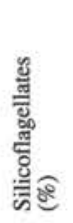 & 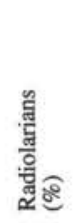 & 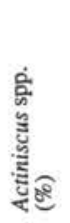 & 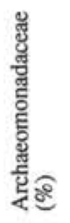 & 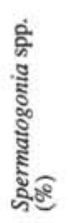 & 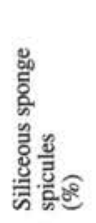 & 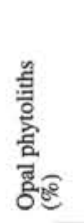 & 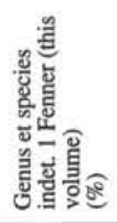 & $\begin{array}{l}\text { 學 } \\
\text { 点。 }\end{array}$ \\
\hline $\begin{array}{l}100-102 \\
130-132\end{array}$ & 5.60 & 8.45 & 0.50 & 0.20 & & & & & & & \\
\hline $\begin{array}{r}130-132 \\
1 \mathrm{H}-5,10-12\end{array}$ & $\begin{array}{l}5.80 \\
6.10\end{array}$ & 7.80 & 0.90 & 0.60 & & & & & & & \\
\hline $\begin{array}{c}1 \mathrm{H}-5,10-12 \\
50-52\end{array}$ & $\begin{array}{l}6.10 \\
6.50\end{array}$ & $\begin{array}{l}6.30 \\
6.30\end{array}$ & $\begin{array}{l}2.00 \\
2.90\end{array}$ & $\begin{array}{l}0.30 \\
0.30\end{array}$ & & & $\begin{array}{l}0.00 \\
0.30\end{array}$ & & & & \\
\hline${ }_{2 \mathrm{H}-1,10-12}^{\mathrm{H}}$ & 6.70 & $\begin{array}{l}0.30 \\
6.80\end{array}$ & 2.40 & $\begin{array}{l}.3 .30 \\
1.30\end{array}$ & 0.20 & 0.20 & 0.00 & & & & \\
\hline $\begin{array}{c}2 \mathrm{H}-1,10-12 \\
50-52\end{array}$ & $\begin{array}{l}6.80 \\
7.20\end{array}$ & $\begin{array}{l}6.30 \\
7.90\end{array}$ & $\begin{array}{l}1.40 \\
0.30\end{array}$ & $\begin{array}{l}0.10 \\
0.30\end{array}$ & $\begin{array}{l}0.30 \\
0.00\end{array}$ & 0.00 & & $\begin{array}{l}0.00 \\
0.20\end{array}$ & & & \\
\hline $90-92$ & 7.60 & 6.60 & 0.80 & 0.60 & & & 0.00 & 0.00 & & & \\
\hline $\begin{array}{r}130-132 \\
2 \mathrm{H}-2,10-12\end{array}$ & 8.00 & 7.20 & 0.80 & 0.60 & & 0.00 & 0.10 & & & & \\
\hline $\begin{array}{c}2 \mathrm{H}-2,10-12 \\
50-52\end{array}$ & $\begin{array}{l}8.30 \\
8.70\end{array}$ & $\begin{array}{l}8.10 \\
8.25\end{array}$ & $\begin{array}{l}0.70 \\
0.50\end{array}$ & $\begin{array}{l}1.90 \\
2.60\end{array}$ & & $\begin{array}{l}0.20 \\
0.00\end{array}$ & & & & & \\
\hline $\begin{array}{l}90-92 \\
130-132\end{array}$ & $\begin{array}{l}9.10 \\
9.50\end{array}$ & $\begin{array}{l}8.10 \\
8.20\end{array}$ & $\begin{array}{l}0.30 \\
0.70\end{array}$ & $\begin{array}{l}2.80 \\
1.20\end{array}$ & $\begin{array}{l}0.00 \\
0.30\end{array}$ & & & & & & \\
\hline $2 \mathrm{H}-3,10-12$ & 9.80 & $\begin{array}{l}8.20 \\
8.30\end{array}$ & 0.00 & 0.90 & 0.00 & & & & & 0.00 & \\
\hline $\begin{array}{l}50-52 \\
90-92\end{array}$ & $\begin{array}{l}10.20 \\
10.60\end{array}$ & $\begin{array}{l}8.00 \\
8.10\end{array}$ & $\begin{array}{l}0.20 \\
1.30\end{array}$ & $\begin{array}{l}0.70 \\
4.10\end{array}$ & $\begin{array}{l}0.20 \\
0.00\end{array}$ & $\begin{array}{l}0.00 \\
0.30\end{array}$ & $\begin{array}{l}0.00 \\
0.10\end{array}$ & & & $\begin{array}{l}0.10 \\
0.00\end{array}$ & \\
\hline $130-132$ & 11.00 & $\begin{array}{l}8.10 \\
8.30\end{array}$ & 0.20 & 1.20 & & 0.00 & 0.00 & & & 0.00 & \\
\hline $\begin{array}{r}2 \mathrm{H}-4,90-92 \\
130-132\end{array}$ & $\begin{array}{l}12.10 \\
12.50\end{array}$ & $\begin{array}{l}7.75 \\
7.70\end{array}$ & $\begin{array}{l}0.60 \\
0.70\end{array}$ & $\begin{array}{l}1.10 \\
0.70\end{array}$ & & & $\begin{array}{l}0.20 \\
0.00\end{array}$ & & & $\begin{array}{l}0.30 \\
0.00\end{array}$ & \\
\hline $2 \mathrm{H}-5,10-12$ & 12.80 & 8.30 & 0.10 & 0.20 & 0.00 & & & & & & \\
\hline $\begin{array}{l}50-52 \\
90-92\end{array}$ & $\begin{array}{l}13.20 \\
13.60\end{array}$ & $\begin{array}{l}7.60 \\
8.30\end{array}$ & $\begin{array}{l}0.40 \\
0.30\end{array}$ & $\begin{array}{l}0.00 \\
0.30\end{array}$ & $\begin{array}{l}0.20 \\
0.00\end{array}$ & & 0.00 & & & & \\
\hline $\begin{array}{r}130-132 \\
2 \mathrm{H}-6,10-12\end{array}$ & 14.00 & 8.25 & 0.30 & 0.00 & 0.30 & & 0.30 & 0.00 & 0.00 & & \\
\hline $\begin{array}{l}2 \mathrm{H}-6,10-12 \\
2 \mathrm{H}-\mathrm{CC}\end{array}$ & $\begin{array}{l}14.30 \\
16.20\end{array}$ & 7.60 & 0.70 & $\begin{array}{l}2.80 \\
2.00\end{array}$ & $\begin{array}{l}0.00 \\
0.20\end{array}$ & $\begin{array}{l}0.00 \\
0.20\end{array}$ & 0.00 & 0.20 & 0.20 & & \\
\hline $3 \mathrm{H}-1,10-12$ & $\begin{array}{l}10.30 \\
16.30\end{array}$ & $\begin{array}{l}0.00 \\
7.70\end{array}$ & 0.00 & $\begin{array}{l}2.00 \\
2.50\end{array}$ & 0.00 & 0.30 & 0.00 & $\begin{array}{l}0.20 \\
0.00\end{array}$ & 0.00 & & \\
\hline $\begin{array}{l}50-52 \\
90-92\end{array}$ & $\begin{array}{l}16.70 \\
17.10\end{array}$ & $\begin{array}{l}7.30 \\
7.00\end{array}$ & $\begin{array}{l}1.00 \\
0.90\end{array}$ & $\begin{array}{l}2.50 \\
2.50\end{array}$ & & $\begin{array}{l}0.00 \\
0.00\end{array}$ & $\begin{array}{l}0.20 \\
0.00\end{array}$ & & & & \\
\hline $130-132$ & 17.50 & 7.20 & 0.80 & 1.90 & 0.00 & 0.50 & 0.25 & & 0.00 & & \\
\hline $\begin{array}{c}3 \mathrm{H}-2,10-12 \\
90-92\end{array}$ & 18.20 & $\begin{array}{l}7.30 \\
7.50\end{array}$ & 1.40 & 1.40 & 0.20 & 0.00 & 0.20 & 0.00 & 0.20 & & \\
\hline $\begin{array}{l}90-92 \\
130-132\end{array}$ & $\begin{array}{l}18.60 \\
19.00\end{array}$ & $\begin{array}{l}7.50 \\
7.40\end{array}$ & $\begin{array}{l}0.70 \\
2.20\end{array}$ & $\begin{array}{l}1.60 \\
1.80\end{array}$ & $\begin{array}{l}0.20 \\
0.00\end{array}$ & $\begin{array}{l}0.90 \\
0.00\end{array}$ & $\begin{array}{l}0.00 \\
0.00\end{array}$ & $\begin{array}{l}0.50 \\
0.20\end{array}$ & $\begin{array}{l}0.20 \\
0.30\end{array}$ & $\begin{array}{l}0.00 \\
0.20\end{array}$ & \\
\hline $3 \mathrm{H}-3,10-12$ & 19.30 & 7.50 & 1.40 & 1.40 & 0.00 & 1.10 & 0.20 & 0.20 & 0.40 & 0.40 & \\
\hline $\begin{array}{r}50-52 \\
90.92\end{array}$ & 19.70 & 7.55 & 1.10 & 3.90 & 0.50 & 0.80 & 0.00 & 0.50 & 0.60 & 0.00 & \\
\hline $\begin{array}{l}90-92 \\
130-132\end{array}$ & $\begin{array}{l}20.10 \\
20.50\end{array}$ & $\begin{array}{l}7.40 \\
7.40\end{array}$ & $\begin{array}{l}0.20 \\
0.90\end{array}$ & $\begin{array}{l}2.80 \\
3.60\end{array}$ & 0.30 & $\begin{array}{l}0.00 \\
0.30\end{array}$ & 0.00 & 0.50 & 0.00 & 0.00 & \\
\hline $3 \mathrm{H}-4,10-12$ & 20.80 & 7.40 & 0.80 & 3.60 & 0.00 & 0.00 & 0.30 & 0.00 & 0.30 & & \\
\hline $\begin{array}{l}50-52 \\
90-92\end{array}$ & $\begin{array}{l}21.20 \\
21.60\end{array}$ & $\begin{array}{l}7.30 \\
7.30\end{array}$ & $\begin{array}{l}1.10 \\
0.70\end{array}$ & $\begin{array}{l}2.00 \\
1.60\end{array}$ & $\begin{array}{l}0.20 \\
0.00\end{array}$ & $\begin{array}{l}0.20 \\
0.00\end{array}$ & $\begin{array}{l}0.40 \\
0.00\end{array}$ & $\begin{array}{l}0.10 \\
0.00\end{array}$ & 0.00 & & \\
\hline $130-132$ & 22.00 & 7.30 & 1.60 & 5.10 & 0.00 & 0.70 & 0.00 & & & & \\
\hline $\begin{array}{c}3 \mathrm{H}-5,10-12 \\
50-52\end{array}$ & $\begin{array}{l}22.30 \\
22.70\end{array}$ & $\begin{array}{l}7.80 \\
8.30\end{array}$ & $\begin{array}{l}0.20 \\
0.90\end{array}$ & $\begin{array}{l}5.40 \\
1.90\end{array}$ & $\begin{array}{l}0.20 \\
0.00\end{array}$ & $\begin{array}{l}0.00 \\
0.40\end{array}$ & $\begin{array}{l}0.20 \\
0.00\end{array}$ & 0.00 & $\begin{array}{l}0.00 \\
0.10\end{array}$ & & \\
\hline $90-92$ & 23.10 & 7.00 & 0.20 & 0.90 & 0.00 & 0.00 & 0.00 & 0.20 & 0.10 & & \\
\hline $130-132$ & 23.50 & 7.20 & 0.30 & 0.80 & 0.00 & 0.30 & 0.30 & 0.00 & 0.00 & & \\
\hline $\begin{array}{c}3 \mathrm{H}-6,10-12 \\
50-52\end{array}$ & $\begin{array}{l}23.80 \\
24.20\end{array}$ & $\begin{array}{l}7.45 \\
7.55\end{array}$ & $\begin{array}{l}2.00 \\
0.20\end{array}$ & $\begin{array}{l}0.60 \\
0.80\end{array}$ & $\begin{array}{l}0.20 \\
0.20\end{array}$ & $\begin{array}{l}0.20 \\
0.00\end{array}$ & $\begin{array}{l}0.10 \\
0.00\end{array}$ & $\begin{array}{l}0.30 \\
0.00\end{array}$ & $\begin{array}{l}0.40 \\
0.00\end{array}$ & 0.00 & \\
\hline $90-92$ & 24.60 & 7.70 & 1.30 & 2.20 & 0.00 & & 0.00 & 0.20 & 0.10 & 0.60 & \\
\hline $\begin{array}{r}130-132 \\
3 \mathrm{H}-7,10-12\end{array}$ & 25.00 & 7.30 & 0.80 & 1.20 & & & 0.20 & 0.00 & 0.00 & 0.00 & \\
\hline $\begin{array}{c}3 \mathrm{H}-7,10-12 \\
50-52\end{array}$ & $\begin{array}{l}25.30 \\
25.70\end{array}$ & $\begin{array}{l}7.60 \\
7.80\end{array}$ & $\begin{array}{l}1.10 \\
0.70\end{array}$ & $\begin{array}{l}3.40 \\
3.60\end{array}$ & & & 0.00 & $\begin{array}{l}0.40 \\
0.00\end{array}$ & $\begin{array}{l}0.60 \\
0.40\end{array}$ & $\begin{array}{l}0.20 \\
3.60\end{array}$ & \\
\hline $3 \mathrm{H}-\mathrm{CC}$ & 25.75 & 7.70 & 0.30 & 1.70 & & 0.00 & & 0.00 & 0.00 & 0.00 & \\
\hline $\begin{array}{c}4 \mathrm{H}-1,100-102 \\
103-104\end{array}$ & 26.70 & 7.50 & 0.90 & 5.30 & 0.00 & 0.70 & & 0.20 & 0.20 & 0.00 & \\
\hline $\begin{array}{l}103-104 \\
140-142\end{array}$ & $\begin{array}{l}26.74 \\
27.10\end{array}$ & $\begin{array}{l}7.70 \\
7.60\end{array}$ & $\begin{array}{l}0.40 \\
0.30\end{array}$ & $\begin{array}{l}2.20 \\
2.10\end{array}$ & $\begin{array}{l}0.20 \\
0.00\end{array}$ & $\begin{array}{l}0.00 \\
0.00\end{array}$ & 0.00 & 0.00 & 0.20 & 0.00 & \\
\hline $4 \mathrm{H}-2,10-12$ & 27.30 & 7.55 & 0.90 & 2.80 & 0.00 & 2.00 & 0.30 & 0.00 & 1.40 & 0.30 & \\
\hline $50-52$ & 27.70 & 7.90 & 0.00 & 4.40 & 0.00 & 0.00 & 0.00 & 0.30 & 0.00 & 0.00 & \\
\hline 60-62 & 27.80 & 7.60 & 0.20 & 0.00 & 0.20 & 0.40 & 0.40 & 0.00 & 0.00 & & \\
\hline $\begin{array}{l}75-77 \\
100-102\end{array}$ & $\begin{array}{l}27.95 \\
2820\end{array}$ & $\begin{array}{l}7.60 \\
7.70\end{array}$ & 0.50 & $\begin{array}{l}5.10 \\
870\end{array}$ & 0.00 & 0.00 & 0.00 & & $\begin{array}{l}0.90 \\
0.00\end{array}$ & & \\
\hline $\begin{array}{r}100-102 \\
103-104\end{array}$ & 28.25 & $\begin{array}{l}7.70 \\
7.70\end{array}$ & 0.80 & 7.00 & & 0.00 & 0.00 & & 0.30 & & \\
\hline $\begin{array}{c}4 \mathrm{H}-3,10-12 \\
50-52\end{array}$ & $\begin{array}{l}28.80 \\
29.20\end{array}$ & $\begin{array}{l}7.80 \\
7.70\end{array}$ & $\begin{array}{l}0.20 \\
0.00\end{array}$ & $\begin{array}{l}2.90 \\
2.40\end{array}$ & & & $\begin{array}{l}0.20 \\
0.00\end{array}$ & $\begin{array}{l}0.00 \\
0.20\end{array}$ & $\begin{array}{l}0.60 \\
0.40\end{array}$ & & \\
\hline 90-92 & 29.60 & 7.65 & 0.50 & 1.20 & & & & 0.50 & 0.00 & 0.80 & \\
\hline $\begin{array}{l}103-104 \\
130-132\end{array}$ & $\begin{array}{l}29.70 \\
30.00\end{array}$ & $\begin{array}{l}7.70 \\
7.70\end{array}$ & $\begin{array}{l}0.20 \\
0.40\end{array}$ & $\begin{array}{r}11.30 \\
5.00\end{array}$ & & & & $\begin{array}{l}0.00 \\
0.00\end{array}$ & 0.00 & $\begin{array}{l}0.20 \\
0.10\end{array}$ & \\
\hline $4 \mathrm{H}-4,10-12$ & 30.30 & 7.70 & 1.50 & 0.90 & & & & 0.20 & 0.20 & 0.20 & \\
\hline $50-52$ & 30.70 & 8.40 & 0.90 & 3.10 & & & & 0.00 & 0.00 & 0.00 & \\
\hline $\begin{array}{l}90-92 \\
103-104\end{array}$ & 31.10 & 7.40 & 0.80 & $\begin{array}{l}2.20 \\
3.00\end{array}$ & & & 0.00 & & $\begin{array}{l}0.20 \\
0.00\end{array}$ & 0.00 & \\
\hline $\begin{array}{l}103-104 \\
110-112\end{array}$ & $\begin{array}{l}31.20 \\
31.30\end{array}$ & $\begin{array}{l}7.60 \\
7.80\end{array}$ & $\begin{array}{l}0.00 \\
0.80\end{array}$ & $\begin{array}{l}3.00 \\
1.10\end{array}$ & 0.00 & & $\begin{array}{l}0.00 \\
0.20\end{array}$ & & 0.08 & 0.00 & \\
\hline $130-132$ & 31.50 & 7.30 & 0.50 & 3.30 & 0.30 & & 0.00 & & 0.00 & & \\
\hline $4 \mathrm{H}-5,10-12$ & 31.80 & 7.30 & 25.50 & 4.80 & 0.00 & & & & 0.20 & & \\
\hline $50-52$ & 32.20 & 8.40 & 0.30 & 0.30 & & & & & 0.00 & & \\
\hline $\begin{array}{l}90-92 \\
103-104\end{array}$ & 32.60 & 7.75 & 0.80 & 1.00 & & & 0.00 & & 0.00 & & \\
\hline $\begin{array}{l}103-104 \\
130-132\end{array}$ & $\begin{array}{l}33.70 \\
33.00\end{array}$ & $\begin{array}{l}7.80 \\
8.10\end{array}$ & $\begin{array}{l}0.20 \\
0.20\end{array}$ & $\begin{array}{l}1.60 \\
1.80\end{array}$ & & & 0.10 & & $\begin{array}{l}0.10 \\
0.10\end{array}$ & & \\
\hline $4 \mathrm{H}-6,10-12$ & 33.30 & 8.10 & 0.10 & 1.10 & & & 0.00 & & 0.00 & & \\
\hline $\begin{array}{l}50-52 \\
90-92\end{array}$ & $\begin{array}{l}33.70 \\
34.10\end{array}$ & $\begin{array}{l}7.90 \\
8.10\end{array}$ & $\begin{array}{l}0.25 \\
0.30\end{array}$ & $\begin{array}{l}1.00 \\
3.40\end{array}$ & & & & & 0.00 & & \\
\hline 103-104 & 34.20 & 8.20 & 0.30 & $\begin{array}{l}1.80 \\
1.80\end{array}$ & & 0.00 & & & 0.30 & & \\
\hline $4 \mathrm{H}-\mathrm{CC}$ & 35.20 & 7.50 & 0.70 & 1.30 & & 0.20 & 0.00 & & 0.00 & & \\
\hline $5 \mathrm{H}-1,30-32$ & $\begin{array}{l}35.50 \\
35.90\end{array}$ & $\begin{array}{l}7.50 \\
7.50\end{array}$ & $\begin{array}{l}1.90 \\
0.75\end{array}$ & $\begin{array}{l}0.80 \\
0.50\end{array}$ & & $\begin{array}{l}1.90 \\
0.50\end{array}$ & $\begin{array}{l}0.20 \\
0.00\end{array}$ & & $\begin{array}{l}0.00 \\
0.70\end{array}$ & & \\
\hline $90-92$ & 36.10 & 7.90 & 0.90 & 4.30 & & 0.00 & & & 0.00 & & \\
\hline $\begin{array}{l}110-112 \\
140-142\end{array}$ & $\begin{array}{l}36.30 \\
3660\end{array}$ & 8.00 & 0.00 & 0.00 & & 0.00 & 0.00 & 0.00 & 0.00 & & \\
\hline $5 \mathrm{H}-2,30-32$ & $\begin{array}{l}36.60 \\
3700\end{array}$ & $\begin{array}{l}7.60 \\
7.50\end{array}$ & $\begin{array}{l}0.80 \\
1.70\end{array}$ & $\begin{array}{l}1.20 \\
3.10\end{array}$ & & 0.60 & 0.20 & 0.20 & 0.20 & & \\
\hline $70-72$ & 37.40 & 7.10 & 3.30 & 2.40 & & & 0.00 & & 0.20 & & \\
\hline $110-112$ & 37.80 & 7.50 & 0.40 & 5.40 & & & & & 0.00 & & \\
\hline $145-147$ & 38.15 & 8.00 & 0.20 & 8.00 & & 0.00 & 0.00 & 0.00 & 0.00 & & \\
\hline $5 \mathrm{H}-3,30-32$ & 38.50 & 7.30 & 1.60 & 1.00 & & 0.30 & 0.30 & 0.30 & 0.20 & 0.00 & \\
\hline $70-72$ & 38 & 7.60 & 0.40 & 8.00 & & 0.00 & 0.00 & 0.00 & 0.00 & 0.02 & \\
\hline $\begin{array}{l}110-112 \\
145-147\end{array}$ & $\begin{array}{l}399.30 \\
39.65\end{array}$ & $\begin{array}{l}7.60 \\
7.70\end{array}$ & $\begin{array}{l}1.90 \\
0.70\end{array}$ & $\begin{array}{l}4.00 \\
1.90\end{array}$ & $\begin{array}{l}0.00 \\
0.30\end{array}$ & & & 0.00 & $\begin{array}{l}0.00 \\
0.20\end{array}$ & 0.00 & \\
\hline $145-141$ & & & & & & & & & & & \\
\hline
\end{tabular}




\begin{tabular}{|c|c|c|c|c|c|c|c|c|c|c|c|}
\hline 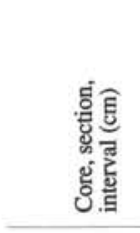 & 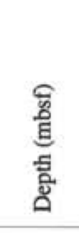 & 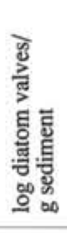 & 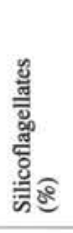 & 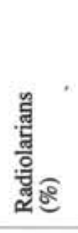 & 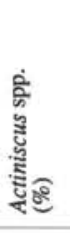 & 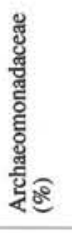 & 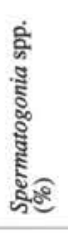 & 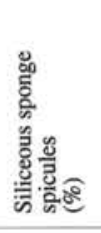 & 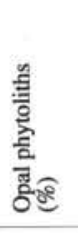 & 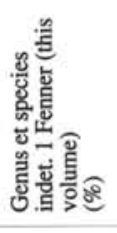 & 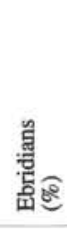 \\
\hline $5 \mathrm{H}-4,30-32$ & 40.00 & 7.80 & 0.80 & 1.00 & 0.00 & & 0.00 & 0.20 & 0.00 & & \\
\hline $\begin{array}{l}70-72 \\
110-112\end{array}$ & 40.40 & 7.20 & 3.10 & 0.50 & & 0.00 & 0.20 & 0.00 & 0.60 & & \\
\hline $145-147$ & $\begin{array}{l}40.80 \\
41.15\end{array}$ & $\begin{array}{l}8.00 \\
7.90\end{array}$ & $\begin{array}{l}1.80 \\
0.60\end{array}$ & $\begin{array}{l}1.00 \\
3.90\end{array}$ & & $\begin{array}{l}0.20 \\
0.00\end{array}$ & 0.00 & $\begin{array}{l}0.00 \\
0.25\end{array}$ & 0.00 & & \\
\hline $\begin{array}{c}5 \mathrm{H}-5,30-32 \\
70-72\end{array}$ & 41.50 & 7.40 & 1.10 & 2.60 & & & & 0.00 & 0.00 & & \\
\hline $\begin{array}{l}70-72 \\
110-112\end{array}$ & 41.90 & 7.60 & 0.70 & 2.10 & & & & 0.00 & 0.70 & & \\
\hline $130-132$ & $\begin{array}{l}42.30 \\
42.50\end{array}$ & $\begin{array}{l}7.20 \\
7.90\end{array}$ & $\begin{array}{l}1.30 \\
0.00\end{array}$ & $\begin{array}{l}2.20 \\
0.30\end{array}$ & & & & 0.00 & 0.00 & & \\
\hline $145-147$ & 42.65 & 7.60 & 1.00 & 3.50 & & & & 0.00 & 0.40 & & \\
\hline $\begin{array}{c}5 \mathrm{H}-6,30-32 \\
70-72\end{array}$ & 43.00 & 8.40 & 0.30 & 0.30 & & & 0.00 & 0.00 & 0.00 & & \\
\hline $70-72$ & 43.40 & 6.70 & 2.00 & 0.80 & & & 0.20 & 0.40 & 1.60 & & \\
\hline $\begin{array}{l}110-112 \\
145-147\end{array}$ & 43.80 & 7.70 & 1.20 & 1.20 & & 0.00 & 0.00 & 0.00 & 0.20 & & \\
\hline $5 \mathrm{H}-7,30-32$ & $\begin{array}{l}44.50 \\
44.50\end{array}$ & $\begin{array}{l}7.80 \\
7.90\end{array}$ & $\begin{array}{l}0.60 \\
0.30\end{array}$ & $\begin{array}{l}2.20 \\
2.30\end{array}$ & & 0.00 & $\begin{array}{l}0.00 \\
0.10\end{array}$ & & 0.10 & & \\
\hline $5 \mathrm{H}-\mathrm{CC}$ & 44.70 & 7.20 & 0.60 & 0.90 & & 0.00 & 0.20 & & 1.60 & & \\
\hline $6 \mathrm{H}-2,60-62$ & 46.80 & 7.90 & 1.00 & 1.20 & & 0.20 & 0.20 & & 0.00 & & \\
\hline $\begin{array}{l}90-92 \\
110-112\end{array}$ & $\begin{array}{l}47.10 \\
47.20\end{array}$ & $\begin{array}{l}7.80 \\
8.60\end{array}$ & $\begin{array}{l}0.00 \\
0.70\end{array}$ & $\begin{array}{l}3.20 \\
2.70\end{array}$ & & $\begin{array}{l}0.20 \\
0.00\end{array}$ & $\begin{array}{l}0.00 \\
0.00\end{array}$ & & $\begin{array}{l}0.20 \\
0.00\end{array}$ & & \\
\hline $\begin{array}{l}10-112 \\
130-132\end{array}$ & $\begin{array}{l}47.20 \\
47.50\end{array}$ & 7.90 & 0.00 & 1.40 & & 0.30 & 0.30 & & 0.00 & & \\
\hline $6 \mathrm{H}-3,10-12$ & 47.80 & 7.90 & 0.80 & 1.60 & & 0.00 & 0.00 & & & & \\
\hline $\begin{array}{l}50-52 \\
90-92\end{array}$ & $\begin{array}{l}48.20 \\
48.60\end{array}$ & $\begin{array}{l}7.80 \\
8.00\end{array}$ & $\begin{array}{l}0.40 \\
0.20\end{array}$ & 2.40 & & 0.10 & 0.00 & & $\begin{array}{l}0.00 \\
0.20\end{array}$ & 0.00 & \\
\hline $130-132$ & 49.00 & 7.60 & 0.40 & 4.30 & & 0.00 & 0.00 & & 0.00 & 0.40 & \\
\hline $6 \mathrm{H}-4,10-12$ & 49.30 & 7.60 & 0.90 & 0.70 & 0.00 & 0.20 & 0.30 & & 0.30 & 0.30 & \\
\hline $50-52$ & 49.70 & 7.70 & 0.90 & 0.60 & 0.30 & 0.00 & 0.00 & 0.00 & 0.00 & 0.60 & \\
\hline $\begin{array}{l}90-92 \\
130-132\end{array}$ & $\begin{array}{l}50.10 \\
50.50\end{array}$ & $\begin{array}{l}7.60 \\
7.60\end{array}$ & $\begin{array}{l}3.60 \\
0.80\end{array}$ & $\begin{array}{l}0.40 \\
0.80\end{array}$ & $\begin{array}{l}0.00 \\
0.80\end{array}$ & 0.00 & & $\begin{array}{l}0.40 \\
0.40\end{array}$ & $\begin{array}{l}0.80 \\
0.40\end{array}$ & $\begin{array}{l}0.30 \\
0.40\end{array}$ & \\
\hline $6 \mathrm{H}-5,10-12$ & 50.80 & 7.60 & 0.60 & 0.80 & 0.00 & 0.20 & & 0.00 & 0.00 & 0.00 & \\
\hline $\begin{array}{l}50-52 \\
90-92\end{array}$ & $\begin{array}{l}51.20 \\
51.60\end{array}$ & $\begin{array}{l}7.90 \\
800\end{array}$ & 0.60 & $\begin{array}{l}1.30 \\
0.20\end{array}$ & & $\begin{array}{l}0.20 \\
0.00\end{array}$ & & 0.10 & 0.40 & $\begin{array}{l}1.30 \\
0.00\end{array}$ & \\
\hline $100-102$ & 51.70 & 7.90 & 0.30 & 0.30 & & $\begin{array}{l}0.00 \\
0.20\end{array}$ & $\begin{array}{l}0.00 \\
0.20\end{array}$ & 0.00 & 0.00 & & \\
\hline $6 \mathrm{H}-6,10-12$ & 52.30 & 8.00 & 0.00 & 0.60 & & 0.60 & 0.40 & & & & \\
\hline $50-52$ & 52.70 & 7.80 & 0.20 & 2.10 & & $\begin{array}{l}0.00 \\
0.20\end{array}$ & 0.00 & & 0.00 & & \\
\hline $\begin{array}{l}90-92 \\
130-132\end{array}$ & $\begin{array}{l}53.10 \\
53.50\end{array}$ & $\begin{array}{l}7.60 \\
7.60\end{array}$ & $\begin{array}{l}0.20 \\
1.10\end{array}$ & $\begin{array}{l}1.40 \\
3.10\end{array}$ & & 0.00 & 0.00 & & 0.20 & & \\
\hline $6 \mathrm{H}-7,10-12$ & 53.80 & 7.60 & 0.60 & 2.10 & & & 0.30 & 0.00 & 0.00 & 0.00 & \\
\hline $50-52$ & 54.20 & 7.60 & 2.90 & 0.70 & & & 0.10 & 0.40 & 0.10 & 0.40 & \\
\hline $\begin{array}{l}50-52 \\
85-87\end{array}$ & 54.20 & 7.30 & 4.10 & 1.30 & & & 0.30 & 0.30 & 0.30 & 0.00 & \\
\hline $\begin{array}{l}{ }^{85-87}-\mathrm{CC} \\
\text { - }\end{array}$ & $\begin{array}{l}54.55 \\
54.60\end{array}$ & $\begin{array}{l}7.30 \\
7.60\end{array}$ & $\begin{array}{l}0.90 \\
0.30\end{array}$ & $\begin{array}{l}0.00 \\
2.30\end{array}$ & & & $\begin{array}{l}0.40 \\
0.30\end{array}$ & 0.00 & $\begin{array}{l}0.40 \\
0.30\end{array}$ & 0.00 & \\
\hline $7 \mathrm{H}-1,80-82$ & 55.00 & 7.70 & 0.00 & 2.80 & & & 0.00 & & 0.30 & 0.30 & \\
\hline $135-137$ & 55.55 & 7.50 & 0.50 & 2.30 & & & 0.00 & 0.00 & 0.00 & 0.00 & \\
\hline $7 \mathrm{H}-2,70-72$ & 56.40 & 7.70 & 0.40 & 1.50 & & & 0.40 & 0.40 & 0.40 & & \\
\hline $110-112$ & 56.80 & 8.00 & 0.50 & 3.70 & & & 0.00 & 0.00 & 0.00 & & \\
\hline $140-142$ & 57.10 & 7.70 & 1.40 & 2.80 & & & 0.20 & 0.00 & 0.60 & 0.00 & \\
\hline $7 \mathrm{H}-3,10-12$ & 57.30 & 7.80 & 1.60 & 3.70 & & & 0.00 & 0.30 & 0.00 & 0.90 & \\
\hline $50-52$ & 57.70 & 7.90 & 0.00 & 2.20 & & & & 0.00 & & 0.20 & \\
\hline $\begin{array}{l}90-92 \\
130-132\end{array}$ & $\begin{array}{r}58.10 \\
58,50\end{array}$ & 8.00 & 0.40 & 1.50 & & 0.00 & & & & 0.20 & \\
\hline $\begin{array}{r}130-132 \\
7 \mathrm{H}-4,10-12\end{array}$ & $\begin{array}{l}58.50 \\
58.80\end{array}$ & $\begin{array}{l}7.90 \\
800\end{array}$ & $\begin{array}{l}0.20 \\
0.40\end{array}$ & 3.10 & & 0.20 & & & & 0.00 & \\
\hline $\begin{array}{c}1 \mathrm{H}-4,10-12 \\
50-52\end{array}$ & 59.20 & 7.90 & $\begin{array}{l}0.40 \\
0.00\end{array}$ & $\begin{array}{l}1.10 \\
1.50\end{array}$ & $\begin{array}{l}0.00 \\
0.30\end{array}$ & 0.00 & & & & & \\
\hline $\begin{array}{l}90-92 \\
130-132\end{array}$ & 59.60 & $\begin{array}{l}7.90 \\
790\end{array}$ & 0.00 & 1.50 & 0.00 & 0.00 & & & & & \\
\hline $\begin{array}{r}130-132 \\
7 \mathrm{H}-5,10-12\end{array}$ & $\begin{array}{l}60.00 \\
60.30\end{array}$ & $\begin{array}{l}7.90 \\
7.50\end{array}$ & 0.20 & $\begin{array}{l}2.80 \\
2.30\end{array}$ & $\begin{array}{l}0.20 \\
0.00\end{array}$ & 0.20 & & & $\begin{array}{l}0.00 \\
0.10\end{array}$ & & \\
\hline $50-52$ & 60.70 & 7.60 & $\begin{array}{l}.00 \\
1.30\end{array}$ & 3.20 & & 0.80 & 0.00 & & 0.00 & & \\
\hline $\begin{array}{l}90-92 \\
130-132\end{array}$ & $\begin{array}{l}61.10 \\
61.50\end{array}$ & $\begin{array}{l}7.70 \\
7.70\end{array}$ & $\begin{array}{l}0.70 \\
1.10\end{array}$ & $\begin{array}{l}3.50 \\
4.40\end{array}$ & & $\begin{array}{l}0.00 \\
0.00\end{array}$ & $\begin{array}{l}0.20 \\
0.00\end{array}$ & & $\begin{array}{l}0.20 \\
0.00\end{array}$ & & \\
\hline $7 \mathrm{H}-6,10-12$ & 61.80 & 7.40 & 1.20 & 1.40 & & 0.50 & 0.20 & 0.00 & 0.90 & 0.00 & \\
\hline & 62.20 & 7.70 & 1.70 & 0.50 & & 0.50 & 0.00 & 0.20 & 0.00 & 0.50 & \\
\hline $\begin{array}{l}90-92 \\
130-132\end{array}$ & 62.60 & 7.50 & $\begin{array}{l}0.00 \\
0.30\end{array}$ & $\begin{array}{l}1.20 \\
950\end{array}$ & & $\begin{array}{l}0.30 \\
0.00\end{array}$ & & 0.00 & 0.90 & 0.90 & \\
\hline $\begin{array}{r}130-132 \\
7 \mathrm{H}-7,10-12\end{array}$ & $\begin{array}{l}63.00 \\
63.30\end{array}$ & $\begin{array}{l}7.80 \\
7.90\end{array}$ & 0.40 & 7.30 & & 0.00 & 0.00 & & 0.00 & & \\
\hline $50-52$ & 63.70 & 7.90 & 0.10 & 2.60 & & 0.20 & 0.05 & & 0.05 & & \\
\hline $7 \mathrm{H}-\mathrm{CC}$ & 63.75 & 7.60 & 0.50 & 4.10 & & 0.50 & 0.00 & & 0.00 & & \\
\hline $8 \mathrm{H}-1,10-12$ & 63.80 & 7.90 & 0.00 & 0.60 & & 0.30 & 0.15 & & 0.15 & & \\
\hline $50-52$ & 64.20 & 7.50 & 1.80 & 2.00 & & 0.20 & 0.00 & 0.00 & 0.90 & & \\
\hline $\begin{array}{r}8 \mathrm{H}-2,50-52 \\
130-132\end{array}$ & 65.70 & 8.00 & 0.60 & 0.20 & & 0.00 & & 0.20 & 0.00 & & \\
\hline $\begin{array}{r}130-132 \\
8 \mathrm{H}-3,10-12\end{array}$ & $\begin{array}{l}66.50 \\
66.80\end{array}$ & $\begin{array}{l}7.75 \\
800\end{array}$ & $\begin{array}{l}0.30 \\
0.00\end{array}$ & $\begin{array}{l}11.30 \\
0.50\end{array}$ & & & 0.00 & 0.50 & & & \\
\hline $\begin{array}{c}8 \mathrm{H}-3,10-12 \\
75-77\end{array}$ & $\begin{array}{l}66.80 \\
67.45\end{array}$ & $\begin{array}{l}8.00 \\
8.00\end{array}$ & 0.30 & $\begin{array}{l}0.50 \\
0.50\end{array}$ & & & $\begin{array}{l}0.30 \\
0.00\end{array}$ & $\begin{array}{l}0.00 \\
0.30\end{array}$ & & & \\
\hline $90-92$ & 67.60 & 8.00 & 1.10 & 1.50 & & & & 0.00 & 0.00 & 0.00 & \\
\hline $130-132$ & 68.00 & 7.90 & 0.80 & 8.10 & & & 0.00 & 0.00 & 0.60 & 0.20 & \\
\hline $8 \mathrm{H}-4,10-12$ & 68.30 & 7.90 & 0.00 & 4.70 & & & 0.40 & 0.70 & 0.00 & 0.00 & \\
\hline $50-52$ & 68.70 & 7.80 & 1.50 & 5.30 & & & 0.20 & 0.00 & 1.00 & & \\
\hline $8 \mathrm{H}-\mathrm{CC}$ & $\begin{array}{l}73.20 \\
73.30\end{array}$ & 7.80 & 0.20 & 2.10 & & $\begin{array}{l}0.00 \\
0.30\end{array}$ & 0.00 & $\begin{array}{l}0.00 \\
0.30\end{array}$ & 0.00 & & \\
\hline $9 \mathrm{H}-1,10-12$ & $\begin{array}{l}73.30 \\
73.70\end{array}$ & $\begin{array}{l}7.90 \\
7.90\end{array}$ & $\begin{array}{l}0.30 \\
0.40\end{array}$ & $\begin{array}{l}1.30 \\
1.50\end{array}$ & & 0.30 & & $\begin{array}{l}0.30 \\
0.40\end{array}$ & 000 & & \\
\hline $\begin{array}{l}50-52 \\
90-92\end{array}$ & $\begin{array}{l}73.10 \\
74.10\end{array}$ & $\begin{array}{l}7.90 \\
7.70\end{array}$ & 0.40 & $\begin{array}{l}1.50 \\
3.10\end{array}$ & & 0.00 & 0.00 & $\begin{array}{l}0.40 \\
0.00\end{array}$ & 0.40 & & \\
\hline $130-132$ & 74.50 & 7.80 & 0.00 & 1.10 & & 0.00 & 0.50 & & 0.00 & & \\
\hline $9 \mathrm{H}-2,10-12$ & $\begin{array}{l}74.80 \\
75.20\end{array}$ & $\begin{array}{l}7.80 \\
7.75\end{array}$ & $\begin{array}{l}0.30 \\
0.40\end{array}$ & $\begin{array}{l}3.10 \\
5.30\end{array}$ & $\begin{array}{l}0.00 \\
0.20\end{array}$ & $\begin{array}{l}0.30 \\
0.20\end{array}$ & 0.00 & $\begin{array}{l}0.00 \\
0.20\end{array}$ & 0.00 & & \\
\hline $90-92$ & 75.60 & 7.83 & 0.70 & 4.30 & 0.00 & 0.00 & 0.00 & 0.00 & 0.30 & 0.00 & \\
\hline $130-132$ & 76.0 & 7.89 & 0.00 & 3.60 & & & 0.30 & & 0.20 & 0.50 & \\
\hline $9 \mathrm{H}-3,10-12$ & $\begin{array}{l}76.30 \\
76.70\end{array}$ & $\begin{array}{l}7.80 \\
7.89\end{array}$ & $\begin{array}{l}0.00 \\
0.20\end{array}$ & $\begin{array}{l}4.70 \\
6.80\end{array}$ & 0.00 & $\begin{array}{l}0.00 \\
0.20\end{array}$ & 0.00 & & $\begin{array}{l}0.00 \\
0.20\end{array}$ & $\begin{array}{l}0.00 \\
0.50\end{array}$ & \\
\hline $\begin{array}{l}30-32 \\
90-92\end{array}$ & 77.10 & 7.67 & 0.90 & & 0.30 & 0.30 & & 0.00 & 0.30 & 0.60 & \\
\hline $130-132$ & 77.50 & 7.83 & 0.40 & 7.70 & 0.00 & 0.20 & & 0.20 & 0.20 & 0.20 & \\
\hline $9 \mathrm{H}-4,10-12$ & 77.80 & 7.56 & 0.00 & 12.90 & & 0.00 & & 0.00 & 0.90 & 0.00 & \\
\hline $\begin{array}{r}50-52 \\
90-92\end{array}$ & $\begin{array}{l}78.20 \\
78.60\end{array}$ & $\begin{array}{l}7.99 \\
7.54\end{array}$ & $\begin{array}{l}0.50 \\
1.30\end{array}$ & $\begin{array}{l}6.90 \\
6.40\end{array}$ & & & & $\begin{array}{l}0.00 \\
0.20\end{array}$ & $\begin{array}{l}0.00 \\
0.20\end{array}$ & 0.00 & \\
\hline $130-132$ & 79. & 7.80 & 0.50 & 13.10 & & & & 0.20 & 0.20 & 0.20 & \\
\hline $9 \mathrm{H}-5,10-12$ & 79. & 7.73 & 1.20 & 8.20 & & & & 0.20 & 0.20 & 0.20 & \\
\hline $\begin{array}{l}50-52 \\
90-92\end{array}$ & $\begin{array}{l}79.70 \\
80.10\end{array}$ & $\begin{array}{l}7.87 \\
7.90\end{array}$ & $\begin{array}{l}0.30 \\
0.20\end{array}$ & $\begin{array}{r}6.90 \\
1260\end{array}$ & & $\begin{array}{l}0.00 \\
0.20\end{array}$ & & $\begin{array}{l}0.20 \\
0.00\end{array}$ & $\begin{array}{l}0.30 \\
0.20\end{array}$ & $\begin{array}{l}1.20 \\
0.70\end{array}$ & \\
\hline r & $\gamma$ & & 0.20 & 12.60 & & 0.20 & & 0.00 & 0.20 & 0.70 & \\
\hline
\end{tabular}




\begin{tabular}{|c|c|c|c|c|c|c|c|c|c|c|c|}
\hline 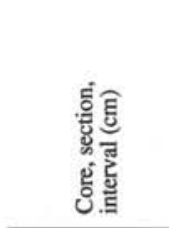 & $\begin{array}{l}\text { है } \\
\text { हE } \\
\text { है } \\
\text { g. }\end{array}$ & 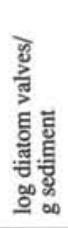 & 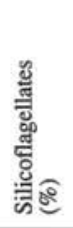 & 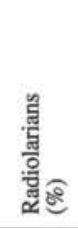 & 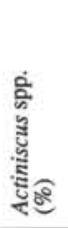 & 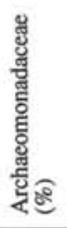 & 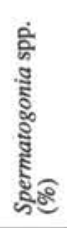 & 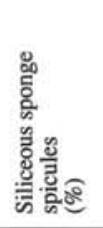 & 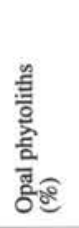 & 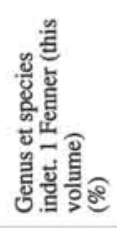 & 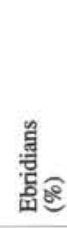 \\
\hline $130-132$ & 80.50 & 7.48 & 0.40 & 13.40 & & 0.00 & & 0.20 & 0.40 & 0.00 & \\
\hline $9 \mathrm{H}-6,10-12$ & 80.80 & 7.87 & $\begin{array}{l}0.40 \\
0.50\end{array}$ & $\begin{array}{r}13.40 \\
8.20\end{array}$ & & 0.00 & 0.00 & 0.00 & 0.00 & 0.00 & \\
\hline $\begin{array}{l}50-52 \\
90-92\end{array}$ & 81.20 & 7.67 & 0.80 & 13.50 & 0.00 & 0.00 & 0.20 & 0.00 & 0.60 & 0.60 & \\
\hline $\begin{array}{l}90-92 \\
130-132\end{array}$ & $\begin{array}{l}81.60 \\
82.00\end{array}$ & $\begin{array}{l}7.56 \\
7.61\end{array}$ & $\begin{array}{l}0.80 \\
1.60\end{array}$ & $\begin{array}{l}8.30 \\
8.90\end{array}$ & 0.20 & $\begin{array}{l}0.20 \\
0.00\end{array}$ & $\begin{array}{l}0.30 \\
0.00\end{array}$ & $\begin{array}{l}0.20 \\
0.00\end{array}$ & $\begin{array}{l}0.50 \\
0.60\end{array}$ & $\begin{array}{l}0.20 \\
0.30\end{array}$ & \\
\hline $9 \mathrm{H}-7,10-12$ & 82.30 & 7.64 & 0.60 & 9.40 & 0.00 & 0.00 & 0.00 & 0.00 & 0.00 & 1.10 & \\
\hline $\begin{array}{l}50-52 \\
9 \mathrm{H}-\mathrm{CC}\end{array}$ & 82.70 & 7.78 & 0.60 & 4.60 & 0.00 & 0.20 & & 0.20 & 0.30 & 0.00 & \\
\hline $\begin{array}{l}9 \mathrm{H}-\mathrm{CC} \\
10 \mathrm{H}-1,10-12\end{array}$ & 82.75 & 7.57 & 1.20 & 9.50 & 0.20 & 0.00 & & 0.00 & 0.60 & & \\
\hline $\begin{array}{c}10 \mathrm{H}-1,10-12 \\
50-52\end{array}$ & $\begin{array}{l}82.80 \\
83.20\end{array}$ & $\begin{array}{l}7.91 \\
7.79\end{array}$ & $\begin{array}{l}0.40 \\
0.30\end{array}$ & $\begin{array}{l}8.40 \\
9.30\end{array}$ & $\begin{array}{l}0.20 \\
0.00\end{array}$ & $\begin{array}{l}0.00 \\
0.50\end{array}$ & & & $\begin{array}{l}0.20 \\
0.00\end{array}$ & & \\
\hline $\begin{array}{l}90-92 \\
130-132\end{array}$ & $\begin{array}{l}83.60 \\
84.00\end{array}$ & $\begin{array}{l}7.92 \\
7.99\end{array}$ & 0.00 & $\begin{array}{l}9.00 \\
6.10\end{array}$ & & $\begin{array}{l}0.00 \\
0.50\end{array}$ & & & & & \\
\hline $10 \mathrm{H}-2,10-12$ & 84.30 & 7.96 & 0.00 & $\begin{array}{r}0.10 \\
11.30\end{array}$ & & 0.00 & $\begin{array}{l}0.00 \\
0.24\end{array}$ & 0.00 & & & \\
\hline $\begin{array}{l}50-52 \\
90-92\end{array}$ & 84.70 & 8.06 & 0.40 & 7.10 & & 0.00 & 0.20 & 0.20 & 0.00 & & \\
\hline $\begin{array}{l}90-92 \\
130-132\end{array}$ & $\begin{array}{l}85.10 \\
85.50\end{array}$ & $\begin{array}{l}7.94 \\
7.81\end{array}$ & $\begin{array}{l}0.20 \\
0.60\end{array}$ & $\begin{array}{l}8.90 \\
9.00\end{array}$ & & $\begin{array}{l}0.50 \\
0.00\end{array}$ & 0.00 & 0.00 & $\begin{array}{l}0.40 \\
0.40\end{array}$ & & \\
\hline $10 \mathrm{H}-3,10-12$ & 85.80 & 7.98 & 0.20 & 9.70 & & 0.40 & & & 0.20 & & \\
\hline $\begin{array}{l}50-52 \\
90-92\end{array}$ & $\begin{array}{l}86.20 \\
86.60\end{array}$ & $\begin{array}{l}7.86 \\
7.86\end{array}$ & $\begin{array}{l}0.00 \\
0.40\end{array}$ & $\begin{array}{r}4.90 \\
10.20\end{array}$ & $\begin{array}{l}0.00 \\
0.20\end{array}$ & $\begin{array}{l}0.30 \\
0.40\end{array}$ & 0.00 & & 0.00 & & \\
\hline $130-132$ & 87.00 & 8.15 & 0.00 & 2.80 & 0.00 & 0.70 & 0.30 & & 0.00 & & \\
\hline $10 \mathrm{H}-4,10-12$ & 87.30 & 7.60 & 0.60 & 13.00 & & 0.40 & 0.20 & & 0.60 & & \\
\hline $\begin{array}{l}50-52 \\
90-92\end{array}$ & $\begin{array}{l}87.70 \\
88.10\end{array}$ & $\begin{array}{l}8.10 \\
7.98\end{array}$ & $\begin{array}{l}0.00 \\
0.00\end{array}$ & $\begin{array}{r}8.10 \\
13.00\end{array}$ & & 0.00 & 0.00 & & $\begin{array}{l}0.00 \\
0.00\end{array}$ & & \\
\hline $130-132$ & 88.50 & 7.89 & 0.40 & 12.00 & & 0.00 & 0.00 & & 0.20 & & \\
\hline $\begin{array}{c}10 \mathrm{H}-5,10-12 \\
50-52\end{array}$ & $\begin{array}{l}88.80 \\
89.20\end{array}$ & $\begin{array}{l}7.93 \\
7.65\end{array}$ & $\begin{array}{l}0.40 \\
0.50\end{array}$ & $\begin{array}{l}8.50 \\
9.80\end{array}$ & & 0.40 & 0.20 & & $\begin{array}{l}0.00 \\
0.50\end{array}$ & $\begin{array}{l}0.00 \\
0.15\end{array}$ & \\
\hline $90-92$ & 89.60 & 7.43 & $\begin{array}{l}.30 \\
1.10\end{array}$ & $\begin{array}{l}9.00 \\
6.70\end{array}$ & & 0.00 & 0.30 & 0.00 & 0.30 & 0.00 & \\
\hline $\begin{array}{c}130-132 \\
10 \mathrm{H}-6,10-12\end{array}$ & $\begin{array}{l}90.00 \\
90.30\end{array}$ & $\begin{array}{l}7.51 \\
7.58\end{array}$ & $\begin{array}{l}0.70 \\
1.80\end{array}$ & $\begin{array}{r}10.30 \\
7.00\end{array}$ & & $\begin{array}{l}0.00 \\
0.40\end{array}$ & 0.00 & $\begin{array}{l}0.50 \\
0.00\end{array}$ & $\begin{array}{l}1.50 \\
0.80\end{array}$ & & \\
\hline $\begin{array}{l}50-52 \\
90-92\end{array}$ & 90.70 & 7.53 & 1.20 & 7.40 & & 0.00 & & & 1.00 & 0.00 & \\
\hline $\begin{array}{l}90-92 \\
130-132\end{array}$ & $\begin{array}{l}91.10 \\
91.50\end{array}$ & $\begin{array}{l}7.72 \\
7.95\end{array}$ & $\begin{array}{l}0.00 \\
0.20\end{array}$ & $\begin{array}{l}9.30 \\
8.80\end{array}$ & 0.00 & $\begin{array}{l}0.20 \\
0.00\end{array}$ & & & $\begin{array}{l}0.20 \\
0.00\end{array}$ & $\begin{array}{l}0.60 \\
0.22\end{array}$ & \\
\hline $10 \mathrm{H}-7,10-12$ & 91.80 & 7.85 & 0.20 & 4.90 & 0.20 & 0.20 & & & 0.20 & 0.00 & \\
\hline $10 \mathrm{H}-\mathrm{CC}$ & 92.20 & 8.07 & 0.20 & 6.70 & 0.00 & 0.00 & & 0.00 & 0.20 & & \\
\hline$\underset{90-92}{11 \mathrm{H}-1,12-12}$ & 92.30 & 7.98 & 0.90 & 1.70 & & & & 0.30 & 0.00 & 0.00 & \\
\hline & $\begin{array}{l}93.10 \\
93.80\end{array}$ & 7.93 & 0.40 & 6.30 & & 0.0 & & 0.00 & 0.20 & 0.20 & \\
\hline $\begin{array}{c}11 \mathrm{H}-2,10-12 \\
90-92\end{array}$ & $\begin{array}{l}93.80 \\
94.60\end{array}$ & $\begin{array}{l}7.90 \\
8.08\end{array}$ & $\begin{array}{l}0.20 \\
0.20\end{array}$ & $\begin{array}{l}6.50 \\
6.90\end{array}$ & & & & 0.00 & 0.00 & $\begin{array}{l}0.00 \\
0.20\end{array}$ & \\
\hline $\begin{array}{c}11 \mathrm{H}-3,10-12 \\
90-92\end{array}$ & 95.30 & 7.96 & 0.30 & 9.90 & & & 0.00 & 0.30 & & 0.00 & \\
\hline $\begin{array}{c}90-92 \\
11 H-4,10-12\end{array}$ & $\begin{array}{l}96.10 \\
96.80\end{array}$ & $\begin{array}{l}8.02 \\
7.84\end{array}$ & $\begin{array}{l}0.20 \\
0.20\end{array}$ & $\begin{array}{r}13.60 \\
6.40\end{array}$ & & & 0.10 & 0.00 & $\begin{array}{l}0.00 \\
0.50\end{array}$ & 0.00 & \\
\hline $50-52$ & 97.20 & 7.97 & 0.70 & 6.80 & & 0.00 & & 0.00 & 0.00 & 0.20 & \\
\hline $90-92$ & 97.60 & 8.09 & 0.50 & 5.00 & & 0.10 & 0.00 & 0.10 & 0.00 & 0.80 & \\
\hline $130-132$ & 98.00 & 8.06 & 0.60 & 2.70 & & 0.00 & 0.10 & 0.00 & 0.10 & 0.00 & \\
\hline $11 \mathrm{H}-6,50-52$ & 100.20 & 7.90 & 0.80 & 6.30 & & 0.10 & 0.00 & & 0.00 & 0.30 & \\
\hline $\begin{array}{l}90-92 \\
130-132\end{array}$ & 100.60 & 8.18 & 0.40 & 5.50 & & 0.20 & & & & 0.00 & \\
\hline $\begin{array}{r}130-132 \\
11 \mathrm{H}-7,10-12\end{array}$ & 101.00 & 8.18 & 0.20 & 5.40 & & 0.00 & & & & & \\
\hline$\underset{50-52}{11 \mathrm{H}-7,12}$ & $\begin{array}{l}101.30 \\
101.70\end{array}$ & $\begin{array}{l}8.06 \\
8.00\end{array}$ & $\begin{array}{l}0.00 \\
0.50\end{array}$ & $\begin{array}{l}6.20 \\
4.60\end{array}$ & 0.20 & & & & 0.00 & & \\
\hline $11 \mathrm{H}-\mathrm{CC}$ & 101.75 & 7.88 & 1.10 & 1.80 & 0.00 & & & & 0.10 & & \\
\hline $12 \mathrm{H}-1,10-12$ & 101.80 & 8.07 & 0.20 & 3.80 & & & & & 0.00 & 0.00 & \\
\hline $\begin{array}{l}50-52 \\
90-92\end{array}$ & $\begin{array}{l}102.20 \\
102.60\end{array}$ & $\begin{array}{l}7.86 \\
7.90\end{array}$ & $\begin{array}{l}0.40 \\
1.20\end{array}$ & $\begin{array}{l}6.70 \\
3.70\end{array}$ & & & & & 0.10 & $\begin{array}{l}0.40 \\
0.30\end{array}$ & \\
\hline $130-132$ & $\begin{array}{l}102.00 \\
103.00\end{array}$ & 8.08 & 0.50 & $\begin{array}{l}3.70 \\
7.30\end{array}$ & & & & & 0.10 & 0.80 & \\
\hline $12 \mathrm{H}-2,10-12$ & 103.30 & 8.11 & 0.40 & 3.90 & & & & & 0.10 & 0.70 & \\
\hline $\begin{array}{l}50-52 \\
90-92\end{array}$ & 103.70 & 7.85 & 0.50 & 6.00 & & & & & 0.10 & 0.50 & \\
\hline $\begin{array}{l}90-92 \\
110-112\end{array}$ & $\begin{array}{l}104.10 \\
104.30\end{array}$ & $\begin{array}{l}8.03 \\
8.04\end{array}$ & $\begin{array}{l}1.30 \\
0.50\end{array}$ & $\begin{array}{l}4.80 \\
4.80\end{array}$ & & & $\begin{array}{l}0.00 \\
0.10\end{array}$ & & $\begin{array}{l}0.20 \\
0.20\end{array}$ & $\begin{array}{l}0.90 \\
0.50\end{array}$ & \\
\hline $130-132$ & 104.50 & 7.92 & 2.30 & 2.70 & & & 0.00 & & 0.00 & 0.00 & \\
\hline $12 \mathrm{H}-3,10-12$ & 104.80 & 8.57 & 1.00 & 1.30 & & 0.30 & & 0.00 & 0.00 & 0.00 & \\
\hline $50-52$ & 105.20 & 7.55 & 1.30 & 2.10 & & 0.40 & & 0.40 & 0.40 & 1.30 & \\
\hline 90 & 105.60 & 7.78 & 0.90 & 0.70 & & 0.00 & & 0.00 & 0.50 & 0.90 & \\
\hline $130-132$ & 106.00 & 7.97 & 0.20 & 1.20 & & 0.10 & & & 0.10 & 0.20 & \\
\hline $12 \mathrm{H}-4,10-12$ & 106.30 & 7.65 & 0.70 & 1.70 & & 3.20 & & & 0.00 & 0.20 & \\
\hline $50-52$ & 106.70 & 7.39 & 0.70 & 1.90 & 0.00 & 0.00 & & & 1.10 & 0.00 & \\
\hline $90-92$ & 107.10 & 7.93 & 1.20 & 1.50 & 0.20 & 0.20 & & & 0.70 & 0.20 & \\
\hline $\begin{array}{c}130-132 \\
12 \mathrm{H}-5,10-12\end{array}$ & 107.50 & 7.39 & 2.00 & 2.60 & 0.00 & 0.00 & & & 0.40 & & \\
\hline $\begin{array}{c}12 \mathrm{H}-5,10-12 \\
50-52\end{array}$ & $\begin{array}{l}107.80 \\
108.20\end{array}$ & $\begin{array}{l}7.81 \\
7.96\end{array}$ & $\begin{array}{l}0.70 \\
1.00\end{array}$ & $\begin{array}{l}1.30 \\
2.90\end{array}$ & & 0.00 & & & $\begin{array}{l}0.60 \\
0.00\end{array}$ & & \\
\hline $\begin{array}{l}90-92 \\
110-112\end{array}$ & 108.60 & 7.60 & 0.80 & 3.40 & & 0.30 & & & & & \\
\hline $130-132$ & $\begin{array}{l}108.80 \\
109.00\end{array}$ & $\begin{array}{l}7.71 \\
7.75\end{array}$ & $\begin{array}{l}0.60 \\
1.90\end{array}$ & $\begin{array}{l}2.20 \\
2.10\end{array}$ & & & $\begin{array}{l}0.00 \\
0.20\end{array}$ & & & $\begin{array}{l}0.00 \\
0.70\end{array}$ & \\
\hline $12 \mathrm{H}-6,10-12$ & 109.30 & 7.92 & 0.90 & 0.30 & & & 0.00 & 0.00 & & 0.00 & \\
\hline $50-52$ & 109.70 & 7.57 & 1.60 & 9.90 & & & 0.00 & 0.20 & & $\begin{array}{l}0.30 \\
0.90\end{array}$ & \\
\hline $\begin{array}{l}90-92 \\
130-132\end{array}$ & 110.10 & 7.94 & 1.10 & 2.50 & & $\begin{array}{l}0.00 \\
0.30\end{array}$ & 0.00 & 0.00 & $\begin{array}{l}0.00 \\
0.30\end{array}$ & 0.90 & \\
\hline $\begin{array}{c}130-132 \\
12 \mathrm{H}-7,10-12\end{array}$ & $\begin{array}{l}110.50 \\
110.80\end{array}$ & $\begin{array}{l}7.97 \\
7.77\end{array}$ & $\begin{array}{l}0.60 \\
0.80\end{array}$ & $\begin{array}{r}9.60 \\
10.50\end{array}$ & & 0.00 & $\begin{array}{l}0.00 \\
0.10\end{array}$ & & 0.10 & $\begin{array}{l}0.60 \\
1.10\end{array}$ & \\
\hline $12 \mathrm{H}-\mathrm{CC}$ & 111.20 & 7.86 & 0.60 & 4.90 & & 0.00 & 0.00 & & 0.00 & 0.30 & 0.90 \\
\hline $13 \mathrm{H}-1,110-112$ & 112.30 & 8.01 & 0.00 & 0.00 & & 0.90 & & & & 0.00 & 0.00 \\
\hline
\end{tabular}

